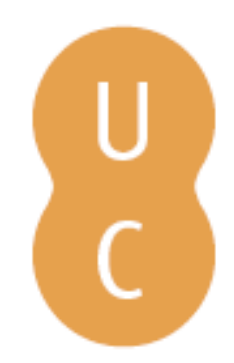

\title{
pompalina
}

\section{O poeta e a cidade no mundo romano}

Publicado por: Centro de Estudos Clássicos e Humanísticos; Imprensa da Universidade

URL

persistente:

URI:http://hdl.handle.net/10316.2/9720

DOI:

DOI:http://dx.doi.org/10.14195/978-989-721-040-2

Accessed : $\quad$ 26-Apr-2023 09:42:46

A navegação consulta e descarregamento dos títulos inseridos nas Bibliotecas Digitais UC Digitalis, UC Pombalina e UC Impactum, pressupõem a aceitação plena e sem reservas dos Termos e Condições de Uso destas Bibliotecas Digitais, disponíveis em https://digitalis.uc.pt/pt-pt/termos.

Conforme exposto nos referidos Termos e Condições de Uso, o descarregamento de títulos de acesso restrito requer uma licença válida de autorização devendo o utilizador aceder ao(s) documento(s) a partir de um endereço de IP da instituição detentora da supramencionada licença.

Ao utilizador é apenas permitido o descarregamento para uso pessoal, pelo que o emprego do(s) título(s) descarregado(s) para outro fim, designadamente comercial, carece de autorização do respetivo autor ou editor da obra.

Na medida em que todas as obras da UC Digitalis se encontram protegidas pelo Código do Direito de Autor e Direitos Conexos e demais legislação aplicável, toda a cópia, parcial ou total, deste documento, nos casos em que é legalmente admitida, deverá conter ou fazer-se acompanhar por este aviso. 


\section{O poeta e a cidade no mundo romano}

\section{Cristina Pimentel, José Luís Brandão, Paolo Fedeli (coords.)}




\section{O poeta e a cidade no mundo romano}

Cristina Pimentel, José Luís Brandão \& Paolo Fedeli (coords.)

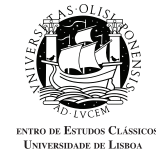


Todos os volumes desta série são sujeitos a arbitragem científica independente.

\section{Coordenadores}

Cristina Pimentel, José Luís Brandão \& Paolo Fedeli

Título

O poeta e a cidade no mundo romano

EDITOR

Centro de Estudos Clássicos e Humanísticos da Universidade de Coimbra

Imprensa da Universidade de Coimbra

\section{EDIÇÃO:}

1a/ 2012

\section{Coordenador Científico do Plano de Edição}

Maria do Céu Fialho

\section{Conselho editorial}

José Ribeiro Ferreira, Maria de Fátima Silva, Francisco de Oliveira e Nair Castro Soares

Director Técnico da Colecção:

Delfim F. Leão

Concepção Gráfica e Paginação:

Rodolfo Lopes, Nelson Ferreira

IMPRESSÃO:

Simões \& Linhares, Lda. Av. Fernando Namora, n. ${ }^{\circ} 83$ Loja 4. 3000 Coimbra

ISBN: 978-989-721-039-6

ISBN DigitaL: 978-989-721-040-2

Depósito Legal: 353376/13

DOI: http://dx.doi.org/10.14195/978-989-721-040-2

(C) IMPRENSA DA UNIVERISDADE DE COIMBRA

(C) Centro de Estudos Clássicos e Humanísticos da Universidade de Coimbra, Centro de Estudos Clássicos da Universidade de Lisboa

(C) Classica Digitalia Vniversitatis Conimbrigensis (http://classicadigitalia.uc.pt)

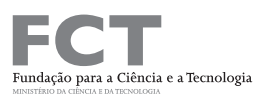

$\mathrm{POCI} / 2010$

Reservados todos os direitos. Nos termos legais fica expressamente proibida a reprodução total ou parcial por qualquer meio, em papel ou em edição electrónica, sem autorização expressa dos titulares dos direitos. É desde já excepcionada a utilização em circuitos académicos fechados para apoio a leccionação ou extensão cultural por via de e-learning. 


\section{SuMÁRIO}

$\begin{array}{ll}\text { Preâmbulo } & 7\end{array}$

O Poeta e a cidade: Virgílio

Cláudia Teixeira

Horácio e Roma: um Poeta e uma cidade em constante Renovação

Pedro Braga Falcão

Tibulo, o Elegíaco da Romanidade

Luís Manuel Gaspar Cerqueira

Dalla città degli amori alla città che cresce: la Roma di Properzio

Paolo Fedeli

I LUOGHI DELLA CATTURA D'AMORE:

A SPASSO CON OVIDIO TRA PORTICI, TEATRI E FORI ROMANI

Rosalba Dimundo

Ovídio, o PoEta NA CidAde

Carlos Ascenso André

A Roma dos Flávios: gente e sentimentos nos Epigramas de Marcial Maria Cristina de Castro-Maia de Sousa Pimentel

Marcial e a URbe: o Meio físico e histórico-social dos epigramas José Luís Lopes Brandão

Uma cidade que fala. Vozes urbanas nas Siluas de Estácio

Ana Maria Lóio

Espaço e perspetiva na obra de Juvenal e na sátira menipeia

Paulo Sérgio Ferreira

Regressar ao Passado na Roma Cristã:

história e ideologia no Panegírico pelo sexto consulado de Honório

Rodrigo Furtado

Bibliografia Geral 


\section{Preâmbulo}

«Pois julgais, irmãos, que a cidade se mede pelos seus muros e não pelos seus cidadãos? ${ }^{1} »$, perguntava Santo Agostinho, pouco tempo depois do saque de Roma em 410, tentando consolar os Romanos perante a devastação causada pelas tropas de Alarico. A Urbe de pedra agonizava, mas os Romanos não. «Pois que é Roma senão os Romanos? Não se trata aqui de pedras, ou de traves, de grandes edifícios ou de extensas muralhas. Tudo isto fora construído de modo que um dia haveria de ruir. Quando o homem construiu, colocou pedra sobre pedra, quando destruiu, derrubou pedra após pedra. O homem fez, o homem desfez. ${ }^{2} \gg$ O Doutor da igreja vaticinava assim, em Hipona, a sobrevivência da ideia da Urbe Eterna e da sua missão, transfigurada pela esperança cristã, muito para além dos seus edifícios materiais. E evocava, no mesmo Sermão 81, as palavras de Virgílio na Eneida e nas Geórgicas, procurando conciliar a promessa de um "império sem fim"3 com a constatação realista de que os bens de Roma e os reinos haveriam de perecer ${ }^{4}$. Não surpreende que, no momento em que a Urbe do Lácio esmorecia, os Romanos se interrogassem sobre as ideias dos seus vates e sobre as voltas da fortuna, na ânsia de compreender a dor insuportável de uma calamidade que parecia impossível de acontecer. Hoje percebemos que não morreu o ideal - mas continuou vivo pelos séculos, a inspirar a cidade e a cidadania. E podemos revisitar, com a exegese enriquecida por dois milénios de civilização, as obras que sobreviveram, mesmo depois de o sumo pontífice ter deixado de subir ao Capitólio com a virgem silenciosa ${ }^{5}$.

\footnotetext{
${ }^{1}$ August. De urb. Exc.6.6. Trad. de Urbano, Carlota M. (2010) Agostinho, O "De excidio Vrbis"e outros sermóes sobre a queda de Roma. Coimbra, CECH., 52.

${ }^{2}$ August. Serm. 81. 9. Trad. de Urbano (2010), cit. 79.

${ }^{3}$ Aen. 1.278-279.

${ }^{4}$ Georg. 2.498.

${ }^{5}$ Cf. Horat. Carm. 3.30.
} 
O presente volume oferece, pois, diversas abordagens da cidade presentes nas obras de Virgílio, Horácio, Tibulo, Propércio, Ovídio, Marcial, Estácio, Juvenal e Claudiano. A ideia de Roma impõe-se de maneira esmagadora nos seus elementos eternos e nos elementos em mutação. O mote é a cidade. Mas Roma afirma-se, como seria de esperar, como pólo aglutinador de culturas, de línguas e de poetas, e como centro irradiador de civilização e critério de rigor linguístico e literário. Aqui se apresenta a Urbe Eterna e a sua missão cantada pelos vates seus filhos naturais ou adoptados, em vários géneros, que vão da epopeia ao epigrama, da ode à elegia, da sátira ao panegírico. Vamos deparando com a cidade enquanto projecto de pátria de Eneias, a cidade real e a cidade ideal, mas também a cidade em metamorfose física ou institucional. Somos transportados sucessivamente através da Roma do final da República, dos Júlio-Cláudios, dos Flávios, dos primeiros Antoninos, e de uma Roma mais tarde órfã dos imperadores, visitada por Honório, escassos anos antes do trauma do saque de Alarico.

A Urbe de tijolo e de mármore também está bem presente. Percorremos os seus lugares imortalizados: os pórticos, as bibliotecas, os templos, as vias, os fora, os teatros, as termas, os palácios, os edifícios públicos e privados que ecoam as vozes urbanas e inspiram prosopopeias da cidade. A Urbe é amiúde pretexto para o diálogo entre a literatura e a arquitectura e apresenta-se sobretudo como o cenário privilegiado dos referidos poetas: representa o espaço da beleza e da deformidade, o espaço do amor, do ódio e da sátira, o espaço da propaganda imperial, o espaço da política e do cosmopolitismo. Mas a cidade tem a sua face de Babilónia e torna-se por vezes o lugar da alienação do poeta, pelo que somos também conduzidos ao inevitável confronto entre cidade e campo.

Pela mão daqueles autores podemos seguir as metamorfoses da cidade eterna nas fracturas e continuidades do trajecto da República para o Império de Augusto, nos efeitos políticos e culturais do alargamento do próprio conceito de cidadão, no evoluir das dinastias do tempo da chamada Pax Romana; mas também perceber as diferenças religiosas e políticas ocorridas entre o alvor dos Antoninos, onde ficamos com Juvenal, e o limiar do século V, a que Claudiano nos transporta, quando a Urbe já pouco mais é que o símbolo da majestade passada. Terminamos assim o volume com o retorno a uma Roma que, tal como no mítico episódio da fundação, aparece, no final, paradoxalmente dividida pelos laços fraternos, transformados em bandeiras da tensão entre Oriente e Ocidente.

Como fruto de colaboração entre Lisboa e Coimbra numa das aulas presenciais do seminário "O poeta e a cidade no Mundo Romano" do doutoramento em Poética e Hermenêutica da FLUC, resultou a ideia de criar este volume, de modo a recolher a pesquisa realizada no âmbito da disciplina, com alargamento a outros autores antigos e estudiosos modernos, para servir de 
material de apoio a futuras edições do curso e ficar à disposição da comunidade de investigadores ou de simples interessados pelos estudos clássicos. O leque dos poetas a considerar foi-se assim alargando até abarcar o conjunto dos nove que aqui se apresentam.

É de salientar que se trata de um trabalho de colaboração entre cidades e universidades, e de conjugação de saberes produzidos nos respectivos centros de investigação: o Centro de Estudos Clássicos e Humanísticos de Coimbra e o Centro de Estudos Clássicos de Lisboa, unidades cuja partilha de conhecimentos e de colaboração no ensino pós-graduado já vem de longa data, às quais se junta a Università degli Studi di Bari, Aldo Moro, através dos investigadores italianos, já nossos habituais colaboradores e conselheiros.

Pelo apoio e o empenho que colocaram nesta edição, cumpre-nos agradecer à Coordenadora do Centro de Estudos Clássicos e Humanísticos, Doutora Maria do Céu Fialho, que, além do mais, foi quem nos sugeriu a compilação do volume, e ao director técnico dos Classica Digitalia, Doutor Delfim Leão, que acompanhou de perto o processo de edição, bem como ao Dr. Nelson Henrique Ferreira que, na qualidade de bolseiro do $\mathrm{CECH}$, formatou o volume.

Cristina Pimentel, José Luís Brandão \& Paolo Fedeli 


\title{
O Poeta e a cidade: Virgílio
}

\author{
Cláudia Teixeira \\ Universidade de Évora \\ Centro de Estudos Clássicos e Humanisticos
}

Se submetêssemos os poetas romanos a um ranking que espelhasse a relação das suas obras com a cidade, Virgílio classificar-se-ia, muito provavelmente, em primeiro lugar. Contudo, afirmar que Virgílio é «o» poeta da cidade envolve contradições surpreendentes. Em primeiro lugar, porque da leitura das suas obras - Bucólicas, Geórgicas e Eneida ${ }^{2}$ - muito dificilmente se ficará com a ideia de que Virgílio era um apreciador de cidades ${ }^{3}$. Na verdade, o sentido maior que visivelmente resulta, sobretudo das duas primeiras, traduz o elogio de um espaço físico e social, no qual as relações se estruturam em uma dimensão que assenta na genuinidade da simplicitas e da paupertas, valores cuja definição se agrupa em torno de um eixo ideológico associado à vida e ao mundo campestres, simples e despojados, e em que a harmonia com a natureza constitui motivo propiciador da criação poética. Em segundo lugar, porque Virgílio não descreve nenhuma cidade, pelo menos como a entendemos hoje, i.e., como um espaço urbano complexo e dinâmico, onde se observam interacções várias e de variadas ordens. O cosmopolitismo de Roma, cidade que, no século I d.C., se firmaria como a primeira cidade do mundo a atingir um milhão de habitantes, o fervilhante tecido social e a heterogeneidade das etnias que nela se cruzavam todos os dias, a sua dimensão económica, que a fazia centro do comércio mediterrânico, o modo de vida dos seus conjuntos populacionais, a demarcação espacial do tecido urbano, com as suas zonas de habitação e de lazer, a cultura popular dos jogos de circo e de anfiteatro, as grandes obras públicas, são, na obra de Virgílio, ou aspectos inexistentes, ou meros potenciais evocados. Todavia, tudo isto não obstaria a que Virgílio fosse considerado «o poeta da cidade». Que cidade? Seguramente da cidade de Roma, mas de uma Roma essencialmente valorativa e ideológica, com topos determinável, mas não espacializada. De uma cidade que, uma vez terminada a guerra civil que opôs, em primeiro lugar, os herdeiros do legado de César à estrutura republicana que planeara e consumara o assassinato do Dictator e, depois, esses mesmos herdeiros entre si, se centra na pacificação do corpo social e na estruturação das

\footnotetext{
${ }^{1}$ Públio Virgílio Marão nasce na aldeia mantuana de Andes a 15 de Outubro de 70 a.C. Falece em 19 a.C., em Brindes, durante o regresso de uma viagem que o levara a Atenas.

${ }^{2}$ As Bucólicas são escritas entre 42-41 a.C. e 39-38 a.C.; as Geórgicas entre 38 e 29 a.C.; a Eneida entre 29 e 19 a.C. Foram ainda atribuídas a Virgílio outras obras menores, reunidas sob a designação de Appendix Vergiliana, consideradas hoje espúrias.

${ }^{3}$ A cidade de Nápoles, à qual, nas Geórgicas, chama dulcis, parece constituir excepção.
} 
relações com as províncias e inaugura uma era que viria a ser conhecida pela designação de Pax romana. É essa era que Virgílio canta na Eneida, uma era complexa, que se constituirá como base da futura Europa moderna, e na qual se desenvolveu uma empresa monumental de incorporação de uma grande quantidade de povos bárbaros em um estado de civilização, assente em um sistema de valores que se pretendia universal. São as premissas desse processo que Virgílio evoca na Eneida ao cantar a missão de um herói troiano, Eneias, que, depois de padecer longos errores, chega ao Lácio para fundar os alicerces da futura Roma. A sua missão ajusta-se, quer por evocação, quer por meio de referenciais explícitos, que vão sendo introduzidos na narrativa, ao processo moldado e modelizado pela visão de um imperador, Augusto, que o Poeta anunciara já na, quarta Bucólica, ao comunicar o nascimento de um Menino que restauraria a Idade do Ouro e cujos feitos expressara também o desejo de cantar, no livro terceiro das Geórgicas. A construção da cidade não resulta, todavia, na Eneida, de um processo simples e linear. Usando o mito para evocar a História e a História para credibilizar o mito, Virgílio constrói a ideia da cidade em um processo complexo e gradual e que, a despeito de confluir para a demonstração das validades intrínsecas do projecto augustano que fará de Roma uma cidade universal, não deixa também de ecoar as suas fragilidades e inconsistências.

\section{A cidade em lugar errado}

A cidade, que na Eneida equivale sobretudo à cidade de Roma, é um conceito que se começa a definir, em primeiro lugar, pela ideia de que, à sua construção, subjaz uma absoluta necessidade de rigor. Assim, longe de assumir de imediato uma teoria política de organização e governo da pólis ou da respublica, Virgílio faz surgir a Urbe como um projecto que se constrói mediante um processo de tentativa e erro. Assim, Trácia ${ }^{4}$ e Creta ${ }^{5}$ constituíram-se como as duas regiões

${ }^{4}$ A tentativa de fixação resulta gorada por um presságio: no decurso de um sacrifício a Vénus, Eneias arranca uns arbustos para decorar os altares da deusa e verifica que das plantas jorra sangue. A explicação do fenómeno é dada pela voz de Polidoro, filho de Príamo, que denuncia a forma como, após a queda de Tróia, fora assassinado por ordem do rei trácio, recém-aliado aos Aqueus. A quebra das normas de hospitalidade e a traição política faz com que a região escolhida se torne inaceitável para o assentamento. Os Troianos deslocam-se a Delos, onde Eneias dirige uma prece a Apolo (3. 85-89) no sentido de obter uma localização espacial para a fixação. A resposta vem na forma de oráculo (3.94-98), cuja ambiguidade leva Anquises a uma interpretação errada, ao associar a tellus referida pelo deus à ilha de Creta.

${ }^{5} \mathrm{Em}$ Creta, a fixação troiana adquire contornos bem definidos: elevam-se os muros da cidade e da cidadela, constituem-se famílias, Eneias distribui os campos e dá as leis ao seu povo. Embora estejam presentes os elementos centrais de qualquer civilização coeva (defesa, organização social e económica, criação do Direito), contudo uma peste dizimadora e a esterilidade dos campos frustram de novo as intenções de estabelecimento. 
onde, após a fuga de Tróia, Eneias primeiramente tenta lançar as bases de uma cidade para assentar o seu povo. Mas o fracasso da empresa fixa positivamente a ideia de que a cidade não se constitui apenas como materialização da vontade ou da necessidade de construir. Marcada ideologicamente pela predeterminação que a faz origem e sede do maior e mais duradouro império alguma vez criado (cf. profecia de Júpiter, 1.278-282), a cidade é equacionada, desde a sua raiz, como uma realidade que, para se cumprir, exige uma fundação ajustada aos ditames sobrenaturais e divinos que a projectam enquanto tal. Nesse sentido, a Cidade surge como uma estrutura física e ideologicamente condicionada, que tem o seu termo a quo na ideia valorativa de que a formação de Roma e, por extensão, do seu império, constitui uma exigência do fatum e da divindade; e o seu termo ad quem na materialização e desenvolvimento de um projecto civilizacional, que tem como requisito primeiro o desenvolver-se em um espaço físico concreto e único, o «espaço ideal», coincidente com o Lácio itálico ${ }^{6}$. Esta coincidência espácio-ideológica é aliás uma ideia com raízes profundas na cultura e no pensamento romanos, porquanto presente já na narrativa mitológica da cidade, anterior à popularização de Eneias como pai-fundador do império: traço central da narrativa de fundação associada ao mito de Rómulo e Remo, no qual a fundação da cidade assume valorativamente o significado de génese, «o mito fundacional, ainda que recorrente e comum na Antiguidade, ganha, em Roma, um carácter especial pela sua função de ordenação do universo romano. O traçado do pomoerium é, consequentemente, uma pequena criação do mundo.» ${ }^{7}$

\section{As cidades possíveis: Butroto.}

Conhecido já, por intervenção apolínea ${ }^{8}$, o termo espacial da viagem, Virgílio começa a desenvolver o espaço ideológico da cidade. $\mathrm{O}$ poeta tem, neste particular, tarefa tão árdua quanto o peso secular da Tróia homérica, pátria de Eneias. Herói menor da Ilíada, fugitivo de Tróia após a destruição da cidade pelos Aqueus, Eneias não recolhia à partida, mesmo a despeito da sua ascendência divina por parte materna, as características centrais de pai-fundador da mais nobre linhagem romana e, por conseguinte, do império criado pelos seus descendentes. Exigia-se, pois, um processo de transformação ou de aquisição dessas características e, para o efeito, o Poeta resgata-o da sua condição inicial, nobilitando-o por meio de um exaustivo processo de heroicização, que cumula

\footnotetext{
${ }^{6}$ Após a tentativa frustrada de estabelecimento em Creta, os deuses Penates aparecem em sonho a Eneias. Apolo revela-lhe, por meio deles, o nome da verdadeira morada a procurar: Itália.

${ }^{7}$ Rodrigues (2005) 16.

${ }^{8}$ Vide nota 6.
} 
o seu estatuto de herói homérico com características que paulatinamente o transformam em herói romano. Processo semelhante exigia a coordenada civilizacional formada pela cidade de Tróia. A Tróia homérica, berço de uma sociedade civilizada, elevada e heróica, constituía uma matriz que, a despeito da sua insuperável fortuna histórico-lendária, exigia superação de forma a que a cidade a criar por Eneias evocasse não a pátria antiga, mas uma pátria efectivamente ajustada ao processo histórico e à evolução material, social e cultural romana. A premência deste objectivo é bem visível na escolha que Virgílio faz da primeira cidade que apresenta, cabalmente constituída, na Eneida. Essa cidade, Butroto, fundada por Héleno e Andrómaca, viúva de Heitor, príncipe e maior herói troiano, apresenta-se como uma «Nova Tróia», ou seja, como uma cidade criada por decalque da antiga cidade-mãe. No entanto, o cenário butrotiano, criado à luz de uma imitatio obsessiva da antiga pátria, redunda em uma simulação árida e estéril, onde sobressaem a cópia da porta Ceia, do túmulo de Heitor, que, neste novo cenário, se encontra inanis, e do Xanto, que, ao contrário do verdadeiro, é arens. A simbologia destas novas propriedades não poderia ser mais clara: «o rio seco significa ausência de água, o elemento, por excelência, ligado ao nascimento e prosperidade das cidades; a porta da cidade, enquanto elemento de identificação da mesma, deveria obedecer, tradicionalmente, a um desenho distinto de todas as outras; e o túmulo vazio ilustra não só uma relação forçada com o passado, mas sobretudo com a sua consequência mais inalterável, ou seja, a morte»". Esta Tróia simulata, desenhada a partir de um modelo de identificação extrema entre o presente e o passado, nada mais representa do que uma cristalização estéril que traduz a ineficácia da cidade enquanto espaço capaz de promover qualquer tipo de reabilitação civilizacional e existencial que não a centrada na reprodução de um passado que já morreu e que, portanto, não tem sentido futuro. Criado o distanciamento que demonstra que a cidade ideal não pode ser mera presa ou imitação de um espaço e de um tempo cujas coordenadas coincidam exclusivamente com outro espaço e outro tempo, resta concluir que, se a romanidade está ainda por definir, a cidade ideal começa a definir-se precisamente por aquilo que não pode ser.

\section{As cidades possíveis: Cartago.}

Antes da chegada ao Lácio, impõe-se mais uma paragem e mais uma cidade. O local escolhido é Cartago e, por meio desta opção, Virgílio recupera

\footnotetext{
9 André (1992) 32; ibidem: «Este simulacro de vida, porém, mais não é do que uma reminiscência da morte, daquilo que os fata exigiam a Eneias que deixasse para trás. Por isso, quando Andrómaca chora o não ter caído em Tróia, como Eneias chorara durante a tempestade, fica a sensação de que o lugar do herói, que o poeta arrancara já à fúria dos elementos e ao desespero de grito semelhante, não pode ser ali.»
} 
uma fase da história romana particularmente significativa. A cidade granjeara o estatuto de arqui-inimiga no momento em que ambas as civilizações disputavam a supremacia sobre o Mediterrâneo. Volvidas as três guerras púnicas, que opuseram as duas potências durante mais de um século (264 a.C.-146 a.C.), Roma sagrou-se vencedora. Cartago foi arrasada, mas, na memória colectiva romana, este conflito internacional nunca deixou de ser paradoxalmente sentido quer como o substantivo e positivo ponto de viragem que permitiu o desenvolvimento da política de hegemonia prosseguida pela Urbe, quer como o acontecimento que mais perto esteve de lhe pôr fim. Essa consciência histórica teria, provavelmente, condicionado a inclusão, na estrutura da Eneida de Virgílio, de um episódio que decorresse em Cartago. E, de igual forma, a importância da relação político-militar da cidade com Roma não deve ter sido alheia ao facto de o Poeta a ter escolhido para palco do maior conflito interior vivido pelo herói na parte odisseica da narrativa e, consequentemente, para obstáculo maior que se põe à consecução da missão. O elemento condutor desse conflito seria, todavia, recuperado da tradição literária pré-virgiliana ${ }^{10}$, que integrava a existência de uma Dido, fundadora e rainha de Cartago ${ }^{11}$. Da conjugação destes três elementos com o plot que os aglutina - a narrativa dos amores trágicos de Dido que, abandonada por Eneias, se suicida - nasce, na verdade, o episódio que se viria a sagrar na posteridade como um dos mais belos e comoventes quadros da literatura latina; um quadro que, contudo, intermediado pelo espaço da cidade, não deixa de estar imbuído de mensagens ideológicas poderosas, que subsidiam o entendimento da obra e do projecto de cidade augustano.

Conhecido o termo ad quem da viagem, o episódio da estada em Cartago funciona, considerado no conjunto da narrativa, como um dos muitos obstáculos que, em quadro épico, o herói deve enfrentar e superar. Todavia a chegada a Cartago após um naufrágio, ordenado pelas forças divinas que corporizam a oposição à empresa, não se vai configurar como mero incidente de percurso desviante, mas sim como o «desvio estrutural» da missão de Eneias; um desvio,

${ }^{10}$ Virgílio parece ter colhido a matéria relativa à rainha de Cartago numa antiga versão do historiador grego Timeu de Tauroménio (FGrHist 566 F 82). Teixeira (2010) 102 observa que «Esta tradição pré-virgiliana continha já, em linhas gerais, os antecedentes eneiádicos do exílio, da fundação de Cartago e a subsequente morte da rainha. Virgílio limita-se, deste modo, a inserir estes elementos na Eneida, refigurando, no entanto, componentes da história, em ajustamento ao quadro poético da sua épica.» Além disso, a história de Dido foi também desenvolvida por Énio (fr. 269); e Justino (Epit. 16.4-6) transmite a história a partir de Trogo. Sobre Névio, Conte (1986) 152 observa: «Virgil probably found Dido in Naevius, but the Bellum Poenicum certainly did not contain the substance of the fourth book of the Aeneid. In Naevius Dido can hardly have been more than a device for taking the date of the historical conflict between the two peoples back to a mythical age.»

${ }_{11}$ Desmond (1994) 33 sustenta que esses elementos da tradição estariam ainda vivos na memória poética dos Poetas augustanos. 
primeiramente físico, mas que rapidamente dá lugar a um desvio ideológico, motivado por uma das grandes forças dinâmicas da literatura, o amor.

Muitos são os estudos que têm chamado a atenção para as várias leituras do episódio e para a articulação entre os elementos literários usados pelo Poeta na sua construção ${ }^{12}$. Mas, em boa verdade, a teia intratextual do episódio não deixa, do nosso ponto de vista, de ter um centro político e ideológico que, mais uma vez, passa pela cidade. Importará, então, averiguar como é que uma magistral história de amor, que articula internamente elementos trágicos, poéticos e épicos, contribui, na sua relação com o todo da obra, para o desenho do projecto da Cidade de forma não menos magistral.

Para tal, é necessário recuar à primeira visão que o Poeta nos oferece de Cartago. À semelhança das cidades que Eneias tentara edificar, Cartago é uma cidade ainda em construção e que consubstancia a materialização de um projecto muito semelhante ao do próprio Eneias: Dido fugira de Tiro, tal como ele próprio fugira de Tróia; e, na companhia de alguns fiéis, estabelece-se no Norte de África, região onde, à semelhança do que ele mesmo intentara na Trácia e em Creta, começa a construção de uma cidade. A visão desse processo é-nos oferecida pelo olhar de Eneias, que, ao chegar a Cartago, admira as portas, a multidão, os pavimentos das ruas, a construção dos muros, da cidadela, de casas de habitação, do porto e do teatro; no centro, elevava-se o templo de Juno, decorado, entre outros motivos, com cenas de combates (incluindo uma representação de si próprio), personagens (os Atridas, Príamo e Aquiles) e quadros célebres (a morte de Troilo; mulheres de Ílio pedindo ajuda a Palas; a súplica de Príamo a Aquiles) da guerra de Tróia ${ }^{13}$. Aos aspectos físicos, juntam-se também elementos políticos: davam-se leis, elegiam-se magistrados e os membros do senado. $\mathrm{O}$ aparecimento da rainha dá continuidade ao motivo da cidade: descrita no âmbito do exercício do poder, Dido supervisiona a construção, administra a justiça, dá as leis e reparte os trabalhos.

Virgílio oferece-nos, assim, a descrição de uma cidade elegante e civilizada e em que a arte, a organização política, a justiça e as leis não passariam despercebidos como indicadores do grau de civilização e da sua qualidade. Todavia, a situação altera-se rapidamente. Após a garantia de bom acolhimento dos troianos por parte da Rainha, é oferecido o tradicional banquete de boas-vindas, no qual o herói conta analepticamente a última noite vivida em Tróia, a fuga e a chegada ao local. A intervenção do enredo divino (Vénus, temendo que Juno interfira e prejudique o acolhimento da rainha,

${ }^{12}$ Entre essas leituras salientam-se as que resultam da análise dos elementos trágicos presentes no episódio; dos estudos relativos aos aspectos romanescos da narrativa; dos estudos relativos à questão do heroísmo de Eneias e ao enredo divino.

${ }^{13}$ Putnam (1998) 24 observa que esses quadros demonstram «how universally celebrated such incidents were and, presumably, how worthy they and their protagonists were of immortality». 
pede a Cupido que inflame em Dido uma paixão por Eneias), produz, além de indiscutíveis efeitos, que se adivinham catastróficos ${ }^{14}$ para o plano individual da rainha, consequências no plano da cidade. $\mathrm{O}$ amor de Dido, divinamente motivado, transforma-se rapidamente em error sentimental, que, por sua vez, apresenta, como efeito último, o abandono dos planos de construção da cidade (4.86-89):

Non coepta adsurgunt turres, non arma iunentus
exercet portusue aut propugnacula bello
tuta parant; pendent opera interrupta minaeque
murorum ingentes aequataque machina caelo.

«Não mais se levantam as torres iniciadas, nem a juventude se exercita nas armas, nem se constroem o porto e os baluartes que garantem a segurança em caso de guerra; quedam suspensos os trabalhos e a enorme ameaça dos muros, máquina que atingia os céus.»

Este abandono vai ganhar uma extensão valorativa, após a consumação desse amor, agenciada pela aliança entre Vénus e Juno, no célebre episódio da caverna (4.165-168), episódio que tem tanto de necessário ao avanço da acção como de polémico ${ }^{15}$. Essa extensão surge cerca de cem versos depois e apenas

${ }^{14}$ Note-se a expressividade da estruturação vocabular usada para a descrição desses efeitos em En., 4.1-5: At regina graui iamdudum saucia cural uolnus alit uenis et caeco carpitur igni./ Multa uiri uirtus animo multusque recursat/gentis honos; baerent infixi pectore uoltus / uerbaque, nec placidam membris dat cura quietem. «Mas a rainha, atingida, há muito, por uma paixão profunda, alimenta uma ferida nas veias que a vai consumindo em um cego fogo. $\mathrm{O}$ valor insigne do herói e a glória do seu povo são recordados incessantemente no seu espírito. O seu rosto e as suas palavras ficam-lhe gravadas no peito e a paixão de que sofre recusa a paz e o sossego aos seus membros.»

${ }^{15}$ Esta polémica resulta, sobretudo, do sentido do subsequente pacto proposto por Juno, força motriz da oposição à missão, e Vénus, força motriz de apoio à empresa, na sequência do enamoramento, em 4.99-104: 'Quin potius pacem aeternam pactosque hymenaeos / exercemus? Habes tota quod mente petisti:/ ardet amans Dido traxitque per ossa furorem./ Communem hunc ergo populum paribusque regamus /auspiciis; liceat Phrygio seruire marito/dotalisque tuae Tyrios permittere dextrae. «Porque não concertamos, pela celebração de um himeneu, uma paz eterna? Tens tudo aquilo a que aspiraste: Dido arde, enamorada, e a paixão trespassa-lhe os ossos. Reinemos, então, com igual autoridade, sobre este povo comum. Que a Dido seja permitido servir um marido frígio e colocar, como dote, os Tírios na tua mão.»). O conhecimento dos elementos veiculados pela profecia de Júpiter no livro primeiro, i.e., de que a estada de Eneias em Cartago não será permanente, permite-lhe concordar com os termos do pacto. No entanto, os termos da pax celebrada entre as deusas não deixam de ser sentidos como ambíguos por parte da crítica. Vide, por exemplo, Miller (1989) 54-55, que realça a ambiguidade do papel das deusas : «the problem becomes more complex when we examine their actual role in the poem, as well as the domains traditionally reserved to the individual goddesses. (....) both figures remain ambiguous. For necessary as each of their functions may be Rome's future, each goddess also embodies a potential threat in her ability to release the passions which subtend it.» 
intercalados pela descrição da divulgação da notícia, levada ao conhecimento dos mortais pela Fama e de Júpiter por Iarbas, e pelo episódio, decorrido no plano divino, no qual o Pai dos deuses envia Mercúrio a Eneias, com a missão de o repreender e de lhe relembrar que o seu destino exige que prossiga viagem. São, com efeito, as primeiras palavras de Mercúrio, enviado a Eneias por Júpiter, que permitem o acesso a essa extensão valorativa (4.265-267):

\section{'Tu nunc Karthaginis altae \\ fundamenta locas pulchramque uxorius urbem extruis?'}

«És tu quem agora lança os alicerces da alta Cartago e levantas, como marido dedicado, uma bela cidade?»

A transferência de funções de Dido para Eneias constitui um acesso ao sentido do episódio e que faz do desfecho da história amorosa não um desfecho motivado apenas pelo amor, perspectivado como elemento do foro individual, mas também, ou mesmo sobretudo, pelo elemento que, em termos da macroestrura do episódio, «(...) traduz (...) o abandono, por parte da rainha, da sua própria missão» ${ }^{16}$. Este é, de facto, elemento amplamente salientado pela escolha dos elementos poéticos e trágicos usados por Virgílio para dar corpo às consequências dessa alienação: o sonho reiterado em que a rainha se vê sozinha, a percorrer um longo e errático caminho e a procurar os Tírios em terra deserta, «constitui um elemento que encerra, em absoluto, «o sentido dicotómico da sua queda e do grau de desvio que a rainha sente em relação àqueles que a seguiram, incondicionalmente, para Cartago» ${ }^{17}$; de igual forma, a perspectivação do futuro, racionalizado pela rainha entre a humilhação de mendigar a união com os povos nómadas da região (4.535-536) e a incerteza que representaria seguir os Troianos (4.537-538), a que se alia a constatação da impossibilidade de começar uma nova empresa ${ }^{18}$ constituem-se como elementos de cariz político que, curiosamente, são a raiz do desejo de morte, que considera merecida ${ }^{19}$; e a constatação que faz no momento em que observa a partida dos Troianos dificilmente poderá ser desligada do contexto do abandono do governo da cidade e, por extensão, da sua missão (4.596-597): Infelix Dido, nunc te facta impia tangunt?/ Tum decuit, cum

${ }^{16}$ Teixeira (2007a) 101.

${ }^{17}$ Teixeira (2008) 14.

${ }^{18}$ Trad. de Cerqueira (2003) 81: 4. 545-546: 'quos Sidonia uix urbe reuelli, / rursus agam pelago et uentis dare uela iubebo?' "conduzirei de novo ao mar e ordenarei que de novo dêem velas ao vento aqueles que eu a custo trouxe da cidade de Sídon?»

19 En., 4.547: Quin morere, ut merita es «Não, morre, como bem mereceste.» Entre estes elementos, o único que parece ter uma natureza estritamente individual é o do reconhecimento da culpa por não ter cumprido a promessa de fidelidade ao defunto marido Siqueu (4.552). 
sceptra dabas. («Desventurada Dido, é agora que a impiedade te abala? Era nessa altura que convinha, quando entregavas o ceptro.»)

Do ponto de vista do herói, Cartago poderia ter sido a cidade possível, como o deixam subentender as palavras que dirige a Dido, quer no livro $\mathrm{IV}^{20}$, quer nos espaço dos infernos ${ }^{21}$. Mas, do ponto de vista da narrativa e dos desígnios do fatum, Cartago pouco mais representou para a missão eneiádica do que um perigo, embora estrutural, como, a breve trecho, lhe recordará o pai Anquises, no decurso da catábase ${ }^{22}$. Além disso, a forma como Virgílio constrói o episódio didoniano, que, a despeito da presença de inúmeros elementos que atestam o recurso ao trágico e a outros subsistemas, não deixa de se consubstanciar como materialização de um projecto épico, permite equacioná-lo como episódio de confronto entre duas missões, a de Dido e a de Eneias ${ }^{23}$. E, tal como na História, esse confronto só poderia terminar, na Eneida, com a vitória daquela que, no seu quadro poético e "poiético», se revelasse mais forte. Acresce que, apesar de a futura cidade estar ainda por definir, Virgílio, ao fazer de Cartago, ainda que momentaneamente e fruto dessa circunstância de indefinição, uma possível alternativa, não a apresenta, todavia, sequer à altura do espaço «ideologicamente vazio» que, neste momento, representa para os troianos o Lácio latino. Cartago é meramente uma grande cidade. Em lugar algum, ao longo do episódio, o Poeta lhe atribui quaisquer características que a permitam ver à luz de um superauit ideológico, que a faça berço de um projecto civilizacional pensado e em grande escala. Por outras palavras, Cartago é uma grande cidade, mas, além de situada «em lugar errado», circunstância que impediria, por si só, o estabelecimento de Eneias e dos troianos, não detém o capital simbólico que lhe permite estar à altura do estatuto do futuro espaço-mãe da romanidade. A prova dessa diferenciação ideológica, que, em termos extratextuais, resulta do

${ }^{20}$ En., 4.360-361: 'Desine meque tuis incendere teque querelis: / Italiam non sponte sequor. ' Deixa de nos atormentar, a mim e a ti, com as tuas lamentações: não é por minha vontade que sigo na rota de Itália.»

${ }^{21}$ En., 6. 458-460: 'Per sidera iuro, / per superos et si qua fides tellure sub ima est, / inuitus, regina, tuo de litore cessi.' "Juro pelas estrelas, pelos deuses do alto e se alguma fé existe nas profundezas da terra, que foi contra a minha vontade, rainha, que deixei as tuas praias."

${ }^{22}$ En. 6. 692-698: 'Quas ego te terras et quanta per aequora uectum / accipio! quantis iactatum, nate, periclis! / Quam metui ne quid Libyae tibi regna nocerent!' "Encontro-te depois de teres percorrido quantas terras e quantos mares! E quantos perigos, meu filho, te atormentaram! Como temi que os reinos da Líbia te fossem danosos!»

${ }^{23}$ Teixeira (2007a) 99-100 observa, a propósito das palavras de Júpiter, em En. 4.223-237, proferidas após o conhecimento de que Eneias se demorava em Cartago: «As palavras do deus e o tom repreensivo são definidores do que, verdadeiramente, representa, no quadro da viagem, a estada em Cartago. As considerações recriminatórias ao papel do herói estão organizadas em torno da ideia de abandono da missão, expresso pelos topoi do esquecimento (fatisque datas non respicit urbis), do incumprimento (Si nulla accendit tantarum gloria rerum / nec super ipse sua molitur laude laborem), do engano (aut qua spe inimica in gente moratur), e da inacção (nec prolem Ausoniam et Lauinia respicit arua?). 
poder evocativo do episódio em relação à História, vai ser expressamente trazida à colação na última parte do discurso profético da rainha, no qual a histórica animosidade entre as duas cidades é perspectivada como mera consequência vindicativa dos acontecimentos vividos no plano individual ${ }^{24}$ (4.622-629):

'Tum uos, o Tyrii, stirpem et genus omne futurum
exercete odiis, cinerique baec mittite nostro
munera. Nullus amor populis nec foedera sunto.
Exoriare aliquis nostris ex ossibus ultor
qui face Dardanios ferroque sequare colonos,
nunc, olim, quocumque dabunt se tempore uires.
Litora litoribus contraria, fluctibus undas
imprecor, arma armis; pugnent ipsique nepotesque.'

«Agora vós, Tírios, persegui com o vosso ódio a sua estirpe e toda a sua descendência vindoura e oferecei esta dádiva às minhas cinzas. Que não existam jamais laços de amizade e alianças entre os dois povos. Levanta-te das nossas ossadas, vingador, quem quer que sejas, e persegue a ferro e fogo os colonos dardânios, agora, mais tarde e em qualquer tempo que haja forças. Praias contra praias, ondas contra mares, armas contra armas, é esta a minha maldição! Que se batam os dois povos e os seus descendentes!»

Deste modo, a evocação das guerras púnicas e de Aníbal, politicamente desenraizada de um projecto civilizacional, opera o derradeiro contraste com o projecto romano que, em breve, vai adquirir contornos de referencialidade histórica e política e revelar-se como um plano de validades intrínsecas que o caucionam como universal.

\section{A cidade ideal: Roma.}

A garantia do triunfo de Eneias e de Roma havia sido dada por Júpiter a Vénus, no livro I da Eneida. Entre os dados relativos ao domínio histórico ${ }^{25}$, o

${ }^{24}$ A profecia «histórica» dá, na verdade, sequência ao tom da primeira parte do discurso, que decorre do plano individual em sentido ainda mais estrito (En. 4.612-620): 'Si tangere portus / infandum caput ac terris adnare necesse est, / et sic fata Iouis poscunt, hic terminus haeret, / at bello audacis populi uexatus et armis, / finibus extorris, complexu auolsus Iuli / auxilium imploret uideatque indigna suorum / funera; nec, cum se sub leges pacis iniquae / tradiderit, regno aut optata luce fruatur,/ sed cadat ante diem mediaque inhumatus harena.' "Se é preciso que essa cabeça nefanda chegue a um porto e que navegue até uma terra; se assim o impõem os fados de Júpiter e se este desígnio é imutável, que, ao menos, atacado, na guerra, pelas armas de um povo audaz, banido para fora dos seus domínios e arrancado aos braços de Iulo, implore auxílio e presencie a infortunada morte dos seus; e que, depois de se ter submetido às leis de uma paz iníqua, não consiga desfrutar da sua realeza, nem da doce luz, mas pereça, antes do tempo, e jaza, insepulto, no meio da areia.»

${ }^{25}$ Quinn (1965) 105, observa que, neste domínio, a profecia está «dangerously close to 
domínio da Grécia pelos romanos (1.282-285), o nascimento de César ${ }^{26}$, que levará o império e a sua fama até aos astros (1.286-288), e o tempo dominado pelo «governo das leis», que emergirá após o fim das guerras civis (1.291-296), haviam sido mencionados pelo deus. Resta, portanto, dar corpo ideológico aos factos e à cidade, enquanto projecto do qual nascerão essas realidades e personagens. Esse esforço não será, no entanto, realizado sem que antes se opere um redimensionamento, no plano da narrativa, de implicações na qualidade desse projecto. Depois de partirem de Cartago, os troianos aportam em Drépano, local onde Eneias recebe, por meio de Anquises, ordens de Júpiter, que o aconselham a levar para Itália apenas os (5.729) lectos iuuenes, fortissima corda («jovens de escol e os corações mais valentes»). Se, no plano imanente da obra, este conselho surge em estreita acomodação ao plano das hostilidades que vai dominar a segunda parte da Eneida, no plano estrutural da narrativa, a nobilitação dos heróis que estarão na génese da cidade e, por extensão, na base da sua História, constitui a primeira intervenção ideológica directa sobre a narrativa - uma intervenção que, lida em cotejo com a narração da história romana feita por Anquises no livro seguinte, não deixa dúvidas sobre a sua intencionalidade.

Após a chegada a Itália no livro VI, tradicionalmente considerado o canto em que se opera a transformação de Eneias em herói romano, movimento que, curiosamente, não deixa de acompanhar a complexa evolução psicológica e existencial do herói, que, no dizer de Pimentel, se vai construindo ao longo da narrativa como «homem em busca de $s i$ mesmo» ${ }^{27}$, a cidade vai, por fim, ser anunciada. $\mathrm{O}$ expediente literário utilizado para esse efeito - a catábase - constitui-se como a mais nobre e transgressora estrutura que, na literatura clássica, é usada para pôr homens e deuses em contacto. E, se a constatação de

propaganda», embora esta intenção seja atenuada pelo facto de que «(....) the prophecy is made a geometric progression to keep within the atmosphere of fairy-tale.» Labate (1987) 79-80, discorda: «Nella profezia di Giove, l'apoteosi del principe è prefigurata da quella di Enea, illustre progenitore della gens Iulia e garante mitico del suo glorioso destino. Si fosse limitato a questo, Virgilio sarebbe di fatto rimasto alle regole di una poesia cortigiana: l'encomio del sovrano prevedeva quello dei suoi antenati, fino a quei divini progenitori cui essi si compiacevano di ricondurre la propria discendenza. (....) Per uscire da questo quadro di omaggio cortigiano, Virgilio aveva bisogno di mettere l'apoteosi del principe in connessione con eroi che non fossero a lui legati da un rapporto di tipo 'dinastico'. (....) A questo punto poteva servire, nell' Eneide, Ercole. (....) Ma Virgilio si allontana dall'encomio ellenistico anche per un altro tratto fondamentale. Le virtù che meritano il cielo (...) non son appannaggio di un individuo, per quanto eccezionale. L'eroe (Eneas o Augusto) impersona le virtù collective del popolo romano.»

${ }^{26}$ A referência a César, em correlação com o verso 288 a magno dimissum nomen Iulo («nome que deriva do grande Iulo»), torna ambígua a identidade do imperador. Williams (1983) 427 e Clark (1974), 7-8, subentendem que a referência diz respeito a Augusto; Quinn (1968) 47, Horsfall (1974) 86-87 e Dobbin (1995) 5-39, consideram que se trata de Júlio César.

${ }^{27}$ Pimentel (1990) 123-182. 
que a entrada no espaço interdito da morte é uma entrada permitida apenas a grandes heróis e movidos por grandes causas (justiça, amor, conhecimento, etc.) bastaria para confirmar o seu carácter excepcional, a decisão de apresentar a cidade em um episódio desta natureza e que, além disso, se encontra no centro formal do poema, confirma a ideia de que essa opção se reveste de uma intencionalidade que, aprioristicamente, pretende caucionar o projecto da cidade de Roma como centro ideológico da épica. Deixando de lado, porquanto colateral ao assunto em causa, o sempre interessante debate sobre a construção literária e filosófica subjacente à caminhada pelo mundo inferior, na qual são evidentes influências da tradição literária grega e articulações de diversas teorias relativas à vida post mortem e à organização do mundo inferior $^{28}$, bem como a primeira parte do episódio, em que Eneias encontra personagens do seu passado (Palinuro, Deífobo e Dido), que lhe permitem fechar de vez o sentido desse passado ${ }^{29}$, centremo-nos na questão da cidade. E, sobre a cidade, a primeira notação ideológica que nos chega vem, precisamente, do Tártaro, locus horribilis ${ }^{30}$ onde se encontram os condenados, interrogados e torturados por Radamanto até confessarem os seus crimes. Além de várias figuras mitológicas, entre os condenados encontram-se também humanos que, em vida, cometeram crimes abomináveis $(6.608-614$ (....); 617-624):

${ }^{28}$ Bailey (reimp. 1969) 243 observa que, na catábase, é possível detectar a presença um substrato ideológico corporizado na «(....) idea of the rewards and punishments of the dead, on which is built (....) a gradually developing popular 'theology' of the world of the dead, with its regions and divisions, and the differentiation of fate_apportioned to various classes of persons, the dead infants, the murdered, the prophets, the heroes, and so on.» Já o substrato filosófico-religioso, que promove a intelectualização do episódio, na linha do Somnium Scipionis e do mito de Er platónico decorrem de, Bailey, ibidem, «(....) two new influences (....). On the one hand were the mystery religions, and in particular Orphism, which promised to the initiate a future life of happiness, on the other the theories of philosophers. Here the doctrine of the Pythagoreans, which was early connected with Orphism, taught a belief in metempsychosis, and influenced the speculations of Plato, while the later teaching of the Stoics, rooted in the belief in the individual soul as a 'fiery particle' of the divine anima mundi, also laid stress on a life after dead.»

${ }^{29}$ Veja-se uma possível explicação para o sentido desses encontros em Teixeira (2007b).

${ }^{30}$ En. 6.548-558: Respicit Aeneas subito et sub rupe sinistra / moenia lata uidet triplici circumdata muro,/ quae rapidus flammis ambit torrentibus amnis,/ Tartareus Phlegethon, torquetque sonantia saxa./ Porta aduersa ingens solidoque adamante columnae,/ uis ut nulla uirum, non ipsi exscindere bello/ caelicolae ualeant; stat ferrea turris ad auras, / Tisiphoneque sedens palla succincta cruenta / uestibulum exsomnis seruat noctesque diesque. Hinc exaudiri gemitus et saeua sonare / uerbera, tum stridor ferri tractaeque catenae. "Olha Eneias de súbito para a esquerda e vê, no sopé de um rochedo, uma gigantesca fortaleza, cercada por tríplice muralha, rodeada por um rio veloz a arder em chamas, o Flegetonte do Tártaro, que faz rolar penhascos retumbantes. Em frente, uma porta enorme e colunas de aço maciço que nenhuma força humana, nem os próprios habitantes do céu as poderiam arrancar em uma guerra. Uma torre de ferro eleva-se nos ares. Tisífone, sentada e cingida num manto ensanguentado, guarda o vestíbulo, noites e dias, sem nunca dormir. Dali saem gemidos e o som de cruéis chicotadas e, depois, o ranger do ferro e o arrastar das correntes.» 
'Hic, quibus inuisi fratres, dum uita manebat, pulsatusue parens et fraus innexa clienti, aut qui dinitiis soli incubuere repertis nec partem posuere suis (quae maxima turba est), quique ob adulterium caesi, quique arma secuti impia nec ueriti dominorum fallere dextras, inclusi poenam exspectant. (....) (....) sedet aeternumque sedebit infelix Theseus, Phlegyasque miserrimus omnis admonet et magna testatur noce per umbras: 'Discite iustitiam moniti et non temnere diuos.' Vendidit hic auro patriam dominumque potentem imposuit; fixit leges pretio atque refixit; bic thalamum inuasit natae uetitosque hymenaeos. Ausi omnes immane nefas ausoque potiti.'

«Aqui estão os que, enquanto a vida durava, odiaram os irmãos, os que levantaram a mão contra o pai e os que defraudaram um cliente, e aqueles que descobriram riquezas e as guardaram só para si e não deram uma parte aos seus (estes são a maior parte); e aqueles que foram mortos por causa de um adultério, os que seguiram armas ímpias e não temeram trair os juramentos feitos aos seus senhores que [aqui] esperam a sua pena. (....). Aí está sentado, e eternamente estará, o infeliz Teseu; e Flégias, o mais desventurado de todos, adverte e testemunha, em alta voz, através das sombras: 'Pela força do exemplo, aprendam a respeitar a justiça e a não desprezar os deuses.' Este vendeu a pátria por ouro e impôs-lhe um tirano; promulgou leis e, por dinheiro, anulou-as; aquele assaltou o tálamo da filha e consumou um himeneu interdito. Ousaram todos um acto monstruoso e dessa ousadia se gozaram.»

A descrição dos condenados ao Tártaro, embora apoiada na tradição literária ${ }^{31}$, opera, todavia, uma significativa ligação à cidade, na medida em que o catálogo dos crimes enunciados assenta, sobretudo, na condenação de delitos contra valores centrais romanos (fides e pietas), perspectivados não apenas nos termos da sua ligação ao indivíduo, mas sobretudo nos termos da sua centralidade e correlatividade com a ordem natural e com a ordem política do Estado: «Once more Virgil has linked ancient and modern thought. His

${ }^{31}$ Williams (1990) 198: «the torments of Tityos, Tantalus, and Sisyphus are described in Homer [Od. 11. 576 ss.], and Tartarus as a place of punishment for the great sinners is an essential part of the Underworld in Platonic myth [Fed. 113e, Górg. 526b]. A fine passage in Lucretius [3. $978 \mathrm{ss}$.] gives the Epicurean rationalization of the myths of Tityos, Tantalus, and Sisyphus, and there are frequent references in Horace's Odes to these familiar figures of literature and folklore. (....) As well as the named sinners the Sybil tells of groups of people defined by their particular sin. This again is traditional, but here is specially pointed by particular relevance to the Roman world in references to family and civil strife (....).» 
Tartarus may be Orphic Tartarus, it may have elements from Homer and Hesiod, but the quiet power with which the poet subjects it all to the simple old code, to the fundamental laws of home and state, takes it out of the region of folklore and brings it home to men with a new force and a new seriousness. Plato had already established moral law beyond the grave (...) and had consigned most "dynasts" to Tartarus, but it was a new thing when Virgil so triumphantly asserted the divine right of the state.»32

Deste modo, as considerações morais que emanam do espaço tartárico constituem, a despeito da aparente diluição com que são introduzidas no contexto, uma aquiescente aproximação ao modelo de legalidade augustano, pautado por uma tentativa de recuperação dos valores antigos, simultaneamente dirigida à regulação do estado e dos particulares (note-se, neste campo, o exemplo representado pelas célebres Leis Júlias, relativas aos casamento e ao adultério) - um modelo a que a Eneida dará sequência explanatória no quadro seguinte. Ultrapassado o Tártaro, o herói chega finalmente ao destino da sua caminhada, o Elísio. Neste espaço luminoso, morada dos bem-aventurados, encontra o pai Anquises, que prontamente responde às questões do filho sobre as (6.706) innumerae gentes populique («inúmeras gentes e povos») que vê em torno do Letes. A mais famosa resposta da épica, batida apenas pela eloquente retirada silenciosa de Dido no canto $\mathrm{VI}^{33}$, vai revelar ao herói que o objectivo da sua missão coincide não apenas com o eixo material e imediato da narrativa que visa o estabelecimento troiano no Lácio, mas também e sobretudo com um eixo ideológico que equivalerá à própria história de Roma. Apoiando-se na teoria da transmigração das almas ${ }^{34}$, que veicula a ideia de que o espaço do Elísio não

${ }^{32}$ Glover (reimp. 1969) 265.

${ }^{33}$ Dido é uma das personagens que Eneias encontra durante a catábase, no lugar destinado às vítimas do durus amor. Eneias dirige-se-lhe e, depois de proferir um emotivo discurso (En., 6.456-466), no qual the diz que foram os deuses que o obrigaram a partir de Cartago, a rainha afasta-se sem proferir palavra.

${ }^{34}$ En. 6.713-751: 'Animae, quibus altera fato / corpora debentur, Lethaei ad fluminis undam/ securos latices et longa obliuia potant./ Has equidem memorare tibi atque ostendere coram / iampridem, hanc prolem cupio enumerare meorum, / quo magis Italia mecum laetere reperta.' / 'O pater, anne aliquas ad caelum binc ire putandum est/ sublimis animas iterumque ad tarda reuerti// corpora? Quae lucis miseris tam dira cupido?'/ 'Dicam equidem nec te suspensum, nate, tenebo.' / suscipit Anchises atque ordine singula pandit. / 'Principio caelum ac terras camposque liquentis / lucentemque globum lunae Titaniaque astra/ spiritus intus alit, totamque infusa per artus / mens agitat molem et magno se corpore miscet./ Inde hominum pecudumque genus uitaeque uolantum / et quae marmoreo fert monstra sub aequore pontus./Igneus est ollis uigor et caelestis origo / seminibus, quantum non noxia corpora tardant / terrenique hebetant artus moribundaque membra. / Hinc metuont capiuntque, dolent gaudentque, neque auras / dispiciunt clausae tenebris et carcere caeco. / Quin et supremo cum lumine uita reliquit, I non tamen omne malum miseris nec funditus omnes /corporeae excedunt pestes, penitusque necesse est / multa diu concreta modis inolescere miris./ Ergo exercentur poenis ueterumque malorum / supplicia expendunt: aliae panduntur inanes / suspensae ad uentos, aliis sub gurgite uasto / infectum eluitur scelus aut exuritur igni; / quisque suos patimur manis. Exinde per amplum / mittimur 
constitui o fim teleológico da alma ${ }^{35}$, Anquises passa a enumerar os Romanos da linhagem de Eneias que vão perpetuar a raça troiana e que se encontram naquele espaço na condição de 'almas nascituras'. Dessa enumeração fazem parte os reis romanos mitológicos Sílvio, Procas, Cápis, Numitor, Sílvio Eneias e Rómulo, o fundador de Roma. Depois, um herói, histórico: César Augusto, que recriará a Idade de Ouro no Lácio e levará o império até aos confins da terra. Regressando à ordem cronológica, interrompida pela referência ao imperador, Anquises cataloga, de seguida, os reis romanos historicamente reconhecidos: Numa Pompílio, Tulo, Anco, os Tarquínios e Bruto, o herói que depôs os Tarquínios e supliciou os próprios filhos, sacrificando a pietas familiar ao sentido de estado ${ }^{36}$. Em seguida, os Décios, os Drusos, Torcato, Camilo,

Elysium et pauci laeta arua tenemus / donec longa dies perfecto temporis orbe / concretam exemit labem purumque relinquit / aetherium sensum atque aurai simplicis ignem. / Has omnis, ubi mille rotam uoluere per annos, / Lethaeum ad fluuium deus euocat agmine magno, / scilicet immemores supera ut conuexa reuisant / rursus, et incipiant in corpora uelle reuerti.' "Estas são as almas às quais o destino deve outros corpos; bebem, junto das ondas do rio Letes, as águas da tranquilidade e os longos esquecimentos. Há muito tempo que desejo falar-te delas, mostrar-tas face a face e enumerar-te a minha descendência, para que, comigo, te alegres ainda mais por teres descoberto a Itália». «Ó meu pai, deve então imaginar-se que algumas destas almas se elevam daqui para o céu para depois regressarem ao peso dos corpos? Que desejo tão cruel da luz há nesses infelizes?» «Eu to revelarei, meu filho, e não te deixarei na incerteza, responde Anquises e expõe-lhe cada destino. 'No princípio, um espírito alimenta por dentro o céu e as terras e as líquidas planícies e o globo luzente da lua e o astro titânio; espalhado pelos membros, o espírito agita a matéria e mistura-se com o seu grande corpo. Daí nascem a raça dos homens e dos animais, as vidas das aves e quantos monstros o mar transporta sob as suas águas marmóreas. Ígneo é o vigor, e celeste a origem destas sementes, enquanto a impureza dos corpos as não detém e as não embrutecem os corpos terrenos e os membros perecíveis. A partir de então, começam a sentir medo, desejos, dor e alegria e, encerradas nas trevas e na escura prisão, deixam de distinguir as brisas do alto. E, quando, no último dia, a vida as deixa, não estão isentas de todo o mal e de todas as máculas do corpo, pois é certo que as impurezas, há muito condensadas, se enraizaram de modo extraordinário. Logo, têm de sofrer os castigos de forma a expiarem, através de suplícios, os males antigos: umas ficam suspensas e expostas aos ventos inanes; outras, é sobre um vasto abismo que a inquinação do crime é queimada ou purificada pelo fogo. Cada um de nós sofre os seus manes. Depois, somos enviados para o vasto Elísio - poucos somos os que habitamos os campos da alegria - até que uma longa jornada, e completado o curso dos tempos, apague a mácula contraída e purifique o espírito etéreo e o fogo do sopro inicial. A todos estes, depois de a roda ter girado mil anos, um deus os chama, em grande esquadrão, para junto do rio Letes, a fim de que, despojados da memória, vejam de novo a abóbada celeste e comecem a querer regressar aos corpos.»

${ }^{35}$ Williams (1990) 201 observa que «The idea that Elysium is not the final paradise but the place from which the blessed move on to their ultimate communion with God is suggested in Plato (e. g. Phaedo 114 c) and seems to have been frequent in Neo-Platonic and Orphic eschatology (....)». Como vários críticos observaram já, a teoria proposta por Virgílio apresenta contradições e inconsistências, que, contudo, são explicáveis tendo em conta que a intenção de Poeta não seria a de criar uma teoria filosófico-religiosa rigorosa, mas apenas dotar o episódio de uma estrutura que proporcionasse, de forma coerente, a introdução da matéria histórica.

${ }^{36}$ Este facto merece comentário de Anquises, que, no quadro ideológico do episódio, não deixa de ser eloquente (En., 6.822-823): 'Infelix! utcumque ferent ea facta minores: / uincet amor 
Pompeio e César. Por fim, Múmio Acaico, Emílio Paulo, Catão e Cósso, os Gracos, os dois Cipiões, Fabrício, Serrano, os Fábios e, entre estes, Máximo.

Se do ponto de vista ficcional, «a convergência da estirpe dos heróis na figura de Eneias constitui um factor que lhe dá a conhecer quer a grandeza, quer a importância da sua missão» ${ }^{37}$, do ponto de vista da relação com a cidade, o catálogo de Anquises representa, mais do que um desfile de factos e personagens, o sentido, ou melhor, «os sentidos» de que se revestiram os vários momentos da história romana e de cujo conjunto resulta o sentido do próprio processo histórico ${ }^{38}$. Significativo, nesse capítulo, é o facto de a perspectiva assumida por Anquises na descrição dos feitos dos heróis historicamente documentados ser muito diferente da perspectiva em que faz o elogio dos heróis mitológicos: «(...) se, aos tempos relativos à história mitológica, que se inicia com Sílvio e termina com Rómulo, corresponde um heroísmo dominado pelo topos da fundação de cidades (pois à acção de cinco reis - Sílvio, Cápis, Numitor, Sílvio Eneias e Rómulo - corresponde a criação de nove cidades), já no que respeita ao tempo histórico esse valor é substituído por um heroísmo de natureza bélica.» ${ }^{39}$ Esta diferença pode ser ampalmente justificada pela importância do topos da fundação entre os Romanos, pelo que, a aceitar este dado, estaríamos, então, na presença de mais um exemplo da incorporação literária da saga mitológica fundacional, tão cara ao pensamento romano, porquanto perspectivada, desde tempos remotos, em contexto de aquisição civilizacional. Mas, a inversão cronológica, que ressalta da identificação de Augusto imediatamente a seguir ao fundador de Roma, Rómulo, e a escolha do

patriae laudumque immensa cupido.' "'Desventurado! Qualquer que seja o juízo que a posteridade emitir sobre estes actos, em ti triunfarão o amor da pátria e o imenso desejo da glória.'»

37 Teixeira (2007a) 191. Boyle (1986) 136, afirma que «This series of forceful moral imperatives, which brings to a climax the vision of Rome's future majesty and greatness (....) constitutes both the first and the only fully overt declaration to Aeneas of the raison d'etre of his mission (....).»

${ }^{38}$ A crítica tem, no entanto, discutido a contradição que parece resultar do uso de um tom de exaltação na descrição de feitos que, na verdade, se revelam pouco morais. Veja-se, a título de exemplo, o comentário de Di Cesare (1974) 118-119 acerca da descrição dos feitos dos generais Múmio Acaico e Emílio Paulo: «Anchises' account takes particular relish in the details of that vengeance to be wrought by the new Troy on Greece. Mummius he characterizes as caesis insignis Achiuis (837: «famous for the Greeks he has slaughtered.») Then he describes the exploits of Aemilius Paullus (....). The details are deliberate and almost sadistic: Paullus will uproot not just Greece, but Argos, the Mycenae of Agamemnon; not just Greeks, but a descendent of Achilles. Thus will he avenge his ancestors and the defiled temples of Trojan Minerva.» Horsfall (1995) 48, observa, por seu lado, que «No question, the Parade contains figures good, bad and ambiguous. Some are already subject to their vices (iam, 816) or bear the instruments of their future cruelty and this is theologically consistent and comprehensible liable even now to the weaknesses of human existence.» Teixeira (2007a) 192 vê estes exemplos como «tributários da evidência de que a perspectiva da enunciação histórica de Anquises vive da subordinação do dever a um sentido de estado.»

${ }^{39}$ Teixeira (2007a) 191. 
tema da expansão romana, expressa em termos mais políticos do que belicistas, para contextualizar de ambas as figuras, não poderá ter explicação tão singela. $\mathrm{Na}$ verdade, o pôr a par e no mesmo contexto o fundador da cidade e o restaurador dessa fundação e, simultaneamente, da Idade do Ouro, não pode deixar de ser lido como uma clara manifestação da legitimação do imperador e da sua política. Estamos, pois, perante a primeira assumpção, ainda que implícita, da Pax romana, o programa imperial que, embora não excluísse a guerra como derradeiro recurso, se pretendia apresentar e apresentava de facto como um projecto de cariz político e civilizacional cujas mais-valias intrínsecas e incomensuráveis benefícios legitimariam a sua aplicação Vrbi et orbi.

Se as considerações de Anquises evocam uma forte perspectiva de Estado (note-se, a título de exemplo, que a única condenação emitida sobre a guerra recai sobre a guerra civil ${ }^{40}$, protagonizada por Pompeio e César ${ }^{41}$, precisamente pelo facto de se tratar de uma guerra fratricida, que opôs romanos a romanos, e, por conseguinte, enfraquecedora da ordem e do Estado), essa perspectiva vai adquirir contornos explícitos, naqueles que são provavelmente os três versos «mais imperialistas» (para usar a expressão de Canfora ${ }^{42}$ ) da Eneida (6. 851-853):

\section{'Tu regere imperio populos, Romane, memento \\ (hae tibi erunt artes), pacique imponere morem, parcere subiectis et debellare superbos.'}

«A ti, Romano, lembra-te, compete reger os povos sob o teu império (estas serão as tuas artes), impor as regras da paz, poupar os submetidos e debelar os arrogantes.»

O corolário normativo das regras de regência do império, enunciado após a narração dos factos e personagens que dão corpo ao devir histórico, configura valorativamente o último estádio desse devir. Na verdade, o modelo rígido de orientação da moral de estado, que as normas deixam subentender, resgata o projecto imperial da feição estritamente expansionista, porquanto o equaciona com um projecto que equivale a um espaço ideológico e, sobretudo, a um espaço

${ }^{40}$ En. 6.832-835: 'Ne, pueri, ne tanta animis adsuescite bella / neu patriae ualidas in uiscera uertite uiris; / tuque prior, tu parce, genus qui ducis Olympo, / proice tela manu, sanguis meus!' "Não, filhos, não habitueis os vossos corações a tantas guerras, nem volteis as vossas forças actuantes contra as entranhas da pátria. E tu, primeiro que todos, tu perdoa, tu que descendes do Olimpo, solta da mão as armas, sangue do meu sangue.»

${ }^{41}$ Curiosamente, omite a que opôs Augusto a Marco António, o que pode ser explicado pelo facto de esta guerra ocupar o centro de outro quadro, i.e., o quadro da écfrasis do escudo de Eneias.

${ }^{42}$ Canfora (2003) 135. 
ético: «Imponere présente morem comme un surplus qui s'ajoute à l'état de paix et lui donne forme et sens. La paix romaine n'est pas seulement l'absence de la guerre, elle sera aussi ordre, légalité, langage commun, civilisation.» ${ }^{43}$

Lançadas as premissas da Pax romana, Virgílio reserva ainda espaço para a demonstração da sua aplicação. Essa demonstração, que ecoa a forma como se constrói o império histórico, vai ocorrer in agendo, na segunda parte da Eneida, dominada pelas guerras que Eneias tem de empreender com os povos locais que tentam impedir o estabelecimento troiano. Contudo, convém realçar que essa demonstração (e por particularidades como esta se vê a complexidade da obra virgiliana) não constitui um acto pensado exclusivamente para comprovar a exequibilidade das normas. Aceitar este pressuposto implicaria condescender com a ideia de que o plano bélico atesta, na épica virgiliana, a validade dos princípios que se pretendem demonstrar meramente pelo seu valor facial. Pelo contrário, não só a gestão da guerra se desenvolve como um processo complexo de negociação e de renegociação, que vai legitimar o sentido da expressão 'Tu regere imperio populos', como, paralelamente a esse processo, são lançados, na narrativa, elementos ideológicos que com ele se articulam e que pretendem legitimar, em sentido universal, a auctoritas que sustenta a Pax Romana e o projecto de cidade que pretende criar.

Esgotadas, no plano da narrativa, todas as diligências diplomáticas condição imposta pelo ideário da Pax romana para a declaração da guerra -, os troianos encontram-se em quadro de hostilidade aberta. A task force formada pelos povos itálicos (e alimentada por Juno) para combater os troianos, obriga Eneias a procurar aliados. A informação do Tibre relativa a um povo descendente de Gregos, os Árcades, instalado na região e governado por Evandro, junto do qual Eneias poderia obter apoio, leva-o a nova missão diplomática, que decorre no livro, o oitavo da Eneida, que ficou conhecido como «o coração augustano do poema» ${ }^{44}$. A escolha para aliado de um povo de origem grega, mas, curiosamente, de ascendência comum à troiana ${ }^{45}$, poderia ser explicada à luz da importância que teve a helenização na formação cultural romana e do facto de a origem mítica de Roma sempre se ter pretendido «fundada na tradição grega, reconhecida, em especial a partir do século II a.C., como superior» ${ }^{46}$. Contudo, esta conciliação entre Troianos e «Gregos» não deixa de ser também reflexo daquilo que Galinsky considera traço fundamental da cultura augustana, ou seja, o pragmatismo da incorporação e da renegociação

\footnotetext{
${ }^{43}$ Perret (1977-1980) 75.

${ }^{44}$ Gransden (1976) 24.

${ }^{45}$ En. 8.127: 'Sic genus amborum scindit se sanguine ab uno.' "Assim, a origem de ambos divide-se a partir de um único sangue.»

${ }^{46}$ Rodrigues (2005) 100.
} 
no contexto das novas necessidades e circunstâncias ${ }^{47}$. Este elemento, que afasta a ideia de que o processo de centralização, implícito nas premissas da Pax romana, se deu de forma linear e apoiado apenas na força hegemónica do imperium vai ainda ser alvo de uma extensão complementar: com efeito, o alargamento da política de coligação aos povos indígenas, que se vai fazer de seguida, não deixa de reflectir igualmente outro traço da pax augustana, ou seja, os esforços da política imperial para estabelecer alianças com povos oriundos de contextos culturais muito distintos ou, como observa Hingley no seu interessante ensaio, o conjunto consciente de políticas de incorporação, agilizadas por Augusto, que se revelaram métodos poderosos de integração social e cultural no império ${ }^{48}$. No entanto, e mais uma vez, o texto virgiliano não se vai limitar a uma mera demonstração pragmática da aplicação desses métodos. A proposta, feita por Evandro a Eneias, para que alie os Etruscos à sua causa, vai introduzir novo elemento ideológico que coincide precisamente com a ideia de que, subjacente às políticas de incorporação, existe um quadro ético que as legitima, como bem o demonstra a construção que se vai fazer a partir da história recente do povo etrusco (8.481-493):

'Hanc multos florentem annos rex deinde superbo
imperio et saeuis tenuit Mezentius armis.'
Quid memorem infandas caedes, quid facta tyranni
effera? Di capiti ipsius generique reseruent!
Mortua quin etiam iungebat corpora uiuis
componens manibusque manus atque oribus ora,
tormenti genus, et sanie taboque fuentis
complexu in misero longa sic morte necabat.
At fessi tandem ciues infanda furentem
armati circumsistunt ipsumque domumque,
obtruncant socios, ignem ad fastigia iactant.
Ille inter caedem Rutulorum elapsus in agros
confugere et Turni defendier hospitis armis.

«Esta cidade floresceu durante muitos anos, até que Mezêncio a submeteu ao seu império soberbo e às suas armas cruéis. Para quê recordar as abomináveis chacinas e as selvagens proezas deste tirano? Que os deuses as façam recair sobre a sua cabeça e a da sua descendência! Ele unia cadáveres a viventes, juntando mãos com mãos e bocas com bocas, tortura medonha, e fazia-os perecer assim, de uma morte lenta, escorrendo sangue e pus em um doloroso amplexo! Mas, um dia, os cidadãos, cansados das atrocidades deste louco, levantam-se em armas, cercam-no a ele e à sua casa, matam os cúmplices e lançam fogo ao

\footnotetext{
${ }^{47}$ Galinsky (1996) 6.

${ }^{48}$ Hingley (2005) cap."The Past in the Present”, 1-13.
} 
palácio. Ele conseguiu escapar, no meio daquela mortandade, e refugiou-se nas terras dos Rútulos, sob a protecção das armas de Turno, que lhe dá defesa e hospitalidade.»

A substância da causa local, i.e., a reposição da justiça e a reparação das injúrias, permite concluir que a incorporação não traduz um movimento que favorece apenas o lado mais forte. Pelo contrário, a incorporação, tal como Virgílio no-la equaciona neste episódio, subentende um traço que, historicamente, se pretendeu fazer habitar no centro nevrálgico da Pax romana: apoiada no conceito de que a necessidade de ordem e de justiça constitui uma aspiração comum a todos os seres humanos, a romanidade apresenta-se como o único espaço ético capaz de lhe dar resposta. E, neste sentido, a entrega do comando a Eneias, ou seja, a Roma, nada mais reproduz do que a razão de força da ideologia incorporativa do imperium: a construção de uma sociedade civilizada necessita de uma soberania forte, cuja liderança consiga debelar a barbárie e ordenar o caos.

Os estudos críticos sobre o livro VIII da Eneida têm observado que não é circunstância despicienda o facto de estes acontecimentos ocorrerem no reino de Evandro, local onde se erguerá a futura cidade de Roma, elemento que é expressamente trazido à narrativa, quando, no centro do livro, Evandro mostra a Eneias os lugares do seu reino que, mais tarde, se constituirão como lugares simbólicos de Roma (a porta Carmental, o bosque do qual Rómulo fez asilo, o Lupercal, o bosque de Argileto, a rocha Tarpeia, o Capitólio e o bairro das Carinas). E é precisamente nesse espaço, presentemente caracterizado por uma vivência de ordem bucólica, baseada em valores antigos como a simplicitas e a paupertas (que, a despeito de se constituírem como valores centrais da romanidade, não deixam de contrastar com a magnificência dos tempos do império), que Virgílio vai ainda proporcionar ao leitor o sentido universal da missão romana. Esse sentido decorre das três narrativas civilizacionais presentes no livro. A primeira é a narrativa heróica de Hércules, que vence Caco, um monstro que assolara a região e se dedicava a constantes carnificinas. A segunda conta a origem da cidade de Evandro, i.e., a sua primeira civilização, proporcionada pela acção do deus Saturno, que reuniu os homens bárbaros ${ }^{49}$ que ali habitavam dispersos pelas montanhas e lhes ensinou a agricultura e

${ }^{49}$ En. 314-318: 'Haec nemora indigenae Fauni Nymphaeque tenebant / gensque uirum truncis et duro robore nata, quis neque mos neque cultus erat nec iungere tauros / aut componere opes norant aut parcere parto, / sed rami atque asper uictu uenatus alebat.' "Estes bosques tinham por habitantes os Faunos e as Ninfas indígenas e uma raça de homens nascida dos troncos do duro carvalho, que não tinham nem tradição, nem cultura, nem conheciam a maneira de atrelar os touros, de armazenar os bens ou de poupar as suas provisões: os ramos e uma penosa caça lhes forneciam alimentos com que viver.» 
as leis, criando a idade de paz e prosperidade que ficou conhecida por Idade do Ouro. A terceira narrativa, e a única que inclui elementos históricos, lê-se da écfrasis do escudo que Vénus oferece a Eneias, após a saída do reino de Evandro, e que desenvolve episódios centrais da história de Roma: a loba que cria Rómulo e Remo; o rapto das Sabinas; o castigo da traição de Meto; a invasão de Porsena; os feitos heróicos de Horácio Cocles e Clélia; a defesa do Capitólio contra os Gauleses, os Sálios e os Lupercos; no centro, a batalha do Áccio, em que estavam representadas as duas facções rivais: de um lado, Augusto, o senado, o povo, Agripa, os Penates e os grandes deuses romanos, Neptuno, Vénus e Minerva; do outro Marco António e Cleópatra, com um exército de homens bárbaros e figuras divinas monstruosas, entre as quais o latrator Anúbis. Por fim, os triunfos de Augusto sobre os Dálmatas, sobre Marco António e sobre Alexandria; e Augusto, sentado à entrada do templo de Apolo, a receber presentes das nações vencidas. No escudo encontra-se também uma representação do Tártaro, onde se encontra Catilina, e do sítio dos justos, onde Catão dá as leis.

A evocação histórica que resulta das acções de civilização nas duas primeiras narrativas, i.e., da aquisição de elementos básicos, mas civilizacionalmente estruturantes, como a agricultura e as leis, na narrativa de Saturno, e da debelação da barbárie, representada por um dos seus mais expressivos símbolos (a associabilidade), na de Hércules e Caco, tem sido um problema bastante discutido pela crítica, uma vez que tanto a aç̧ão do deus como a do herói promovem evidentes paralelos com o programa augustano da Pax romana. Se a história do deus centraliza o leitmotiv do programa augustano no tocante à política externa, i.e., «a reunião dos povos» como condição necessária para a sua dotação civilizacional, a história de Hércules e Caco «(....) is treated with an evident and purposeful consciousness of an analogy between Hercules and the younger Caesar, Octavian, victor of Actium and restorer of peace to the Roman world. Both are performers of prodigious feats, both are benefactors of mankind, liberating the world from terrors and oppressors and making it possible for life to be lived in peace.» ${ }^{50}$

De igual forma, a écfrasis, que desenvolve o topos da ordem vs desordem, constitui um poderoso alerta contra os efeitos da «barbárie» de natureza social e política, susceptível de destruir pela base uma sociedade já organizada. Além do alerta contra a ameaça exógena (que prolonga o motivo saturniano de que a união dos povos é condição básica para a civilização), promovida pela representação pictórica daqueles que não querem aderir ao programa 197.

${ }^{50}$ Camps (1969) 98-99. O autor desenvolve os paralelos entre Hércules e Augusto, ibidem, 
(significativa é a presença no escudo de Gauleses, Sálios e Lupercos), a reprovação da «barbárie» endógena (que, inclusive, surge religiosamente sancionada pela inclusão de Catilina no Tártaro) dá sequência ao quadro de censura inaugurado, no livro VI, no momento em que Anquises reprova a guerra civil. Contudo, agora, a questão centra-se não na guerra entre César e Pompeio ${ }^{51}$, mas no grande acontecimento recente da história romana, a batalha do Áccio, cujo desfecho constituiu o ponto de alavancagem do programa da Pax. A vitória de Augusto sobre Marco António, aliado a uma rainha e a um reino bárbaros ${ }^{52}$, promove definitivamente o fim da desunião interna e «(...) delimits Augustus' prowess as the outcome of a historical design initiated by heaven. Not only is the battle of Actium portrayed as a theomachy but the gods also foster the collective elements, Italian and Roman, which invest Augustus' victory.» ${ }^{53}$

Deste episódio resulta igualmente o valor dado à guerra, no quadro da Pax romana, i.e., a guerra como expediente de recondução à harmonia social e política, que tem justificação apenas quando se combate a promoção do caos e da desordem e quando o seu fim último coincide com a instituição da paz. Igitur qui desiderat pacem, praeparet bellum ${ }^{54}$, dirá Vegécio alguns séculos depois, provavelmente sem consciência do ainda mais terrível sentido que a posteridade havia de retirar das suas palavras.

A justificação da vitória de Eneias e dos seus aliados sobre a confederação itálica lança-a Virgílio, em episódios esparsos, ao longo dos últimos quatro livros da Eneida. Os valores decorrentes desses episódios podem facilmente topicalizar-se no motivo civilizacional, que, desde as primeiras linhas do poema, o Poeta associou tanto ao tellus da missão eneiádica como ao da realidade histórica que aquela pretende reflectir. Em suma, a vitória troiana justifica-se, porque o modelo de civilização que a missão de Eneias pressupõe contém

${ }^{51} \mathrm{O}$ desenvolvimento do tema da guerra civil entre Marco António e Augusto, neste episódio, pode explicar a sua omissão no livro VI.

${ }^{52} \mathrm{O}$ tópico da barbárie egípcia, visível, entre outros aspectos, na questão do teriomorfismo divino, constituiu, provavelmente, o leitmotiv mais forte da propaganda augustana contra Marco António. Veja-se, por exemplo, o discurso de Augusto às tropas, reproduzido em Díon Cássio (50.24-28), onde se afirma que Alexandrinos e Egípcios cultuam répteis e bestas na qualidade de deuses; António abandonou os costumes dos antepassados, emulou costumes estrangeiros e bárbaros e presta honra não aos deuses romanos, mas a Cleópatra como se ela fosse Ísis ou Selene e tomando para si próprio o título de Osíris ou Dioniso. O discurso contém, nesta sequência, um apelo a que ninguém considere Marco António romano, mas antes egípcio, e a que ninguém lhe chame António, mas Serápis.

${ }^{53}$ Botha (1992) 14.

${ }^{54}$ Vegécio, Epitoma Rei Militaris, 3, prefácio: (...) Igitur qui desiderat pacem, praeparet bellum; qui uictoriam cupit, milites inbuat diligenter; qui secundos optat euentus, dimicet arte, non casu. Nemo prouocare, nemo audet offendere quem intellegit superiorem esse, si pugnet. O preceito equivale ao do provérbio latino Si uis pacem, para bellum. 
já os traços que as regras, enunciadas por Anquises no livro VI (poupar os submetidos e debelar os soberbos), subentendem. A título de exemplo, vejam-se os elementos sugeridos pelo comportamento dos heróis que representam as duas partes em conflito: Turno sucumbe estruturalmente ao furor e à ira, de resto, em estreita conformidade com as características promovidas pelas suas divindades protectoras (Juno e Alecto), ao passo que essas manifestações são meramente residuais em Eneias ${ }^{55}$. Essa propensão não passaria despercebida ao leitor da Eneida, situado no tempo de Augusto, como manifestação de um comportamento «irracional» e "próximo da natureza», características que qualquer romano comum associaria à «barbárie», uma vez que tanto os conceitos amplamente difundidos sobre a irracionalidade e comportamento estranho das populações bárbaras, como as imagens estereotipadas, que a propaganda encomendava para decorar arcos do triunfo e monumentos, promoviam essa associação. ${ }^{56}$ Mas, mais importante ainda é o facto de, em contraste com Eneias, a actuação de Turno não evidenciar princípios morais. Novamente a título de exemplo, veja-se esse contraste em dois episódios similares, em que ambos defrontam dois inimigos: Eneias reconhece a inferioridade do adversário, o jovem Lauso, e tenta demovê-lo do combate; Turno, nas mesmas circunstâncias, assume a sua superioridade e só lamenta que Evandro, o pai de Palante que agora defronta, não esteja presente para ver a morte do filho; vencidos os inimigos, Eneias lamenta a sorte de Lauso e entrega o corpo do jovem sem o despojar das armas; Turno, pelo contrário, despoja o cadáver de Palante - sem consciência de que este gesto, tragicamente irónico, acabaria por selar o seu próprio destino.

Os episódios retomam novamente o tema da política de incorporação visada pelo programa da Pax. Contrariamente ao que sucedera no episódio etrusco, a ausência de uma substância moral na actuação de Turno, acompanhada pela resistência que demonstra à formulação de um acordo pacífico, coloca-o do lado de todos aqueles que não reconhecem a «romanidade» como um sistema integrador e que, tal como propagandeado pelo programa da $P a x$, visava proporcionar condições para a civilização e para a realização do seu potencial máximo. Esta constatação, que mais não é do que uma justificação ideológica para legitimar a conquista e a governação dos povos absorvidos na estrutura do império, permite entender as premissas subjacentes às regras de orientação do império, enunciadas por Anquises: aos romanos compete governar o mundo (6.851). Mas governar o mundo constitui uma circunstância que, como a própria história romana e a extensa produção de textos políticos sobre a res publica já haviam demonstrado, pode

\footnotetext{
${ }^{55}$ Eneias é considerado saeuus, em 10.569, furens, em 10.545 e iratus, em 12.946.

${ }^{56}$ Vide Hingley (2005) 61-62.
} 
ser exercida de muitas formas. Por isso, não é de estranhar que, nos dois versos seguintes (6.852-853), Anquises enuncie as premissas subjacentes ao exercício desse governo: impor as regras da paz, poupar os submetidos e debelar os arrogantes. Que os segmentos desta proposição justificam a vitória de Eneias sobre Turno parece constatação inquestionável no quadro da narrativa. No entanto, esses versos não deixam de expressar igualmente uma vitória que ultrapassa as fronteiras do episódio: a vitória da convicção, que se hegemonizaria na própria consciência cultural romana, da excelência do modelo - de um modelo grandioso e que teve o dom de se criar como base da Europa moderna, mas que, como em todos os processos históricos, não teria deixado de silenciar a legítima aspiração à diferença e o não articulável, como bem parece sintetizar a célebre frase, a despeito de proferida em quadro ficcional e evocativo de época posterior à de Augusto, «A people should know when they are conquered...» ${ }^{57}$.

A possível consciência virgiliana de que o projecto da cidade implica uma concretização que nem sempre se ajusta à bondade inscrita no modelo constitui um dado aferível da última cena da narrativa. Nos últimos versos do poema, Turno reconhece-se uictus e suplica a Eneias pela vida. Eneias lembra-se da morte de Palante e mata o suplicante, em total desajuste com a norma, enunciada por Anquises, que determinava "poupar os submetidos» (6.853).

Este episódio, juntamente com outros elementos esparsamente lançados ao longo do texto, constitui-se como base de uma escola interpretativa da Eneida, que se opôs à chamada «escola europeia», designação que reúne as leituras que tendem a ver o texto como uma celebração de um momento histórico, que fundou, apoiado nos fundamentos éticos, morais e políticos da sociedade romana, não só um império, mas uma nova ordem global. Em oposição a esta leitura, a denominada «escola pessimista» ${ }^{58}$ ou «escola de Harvard» dá relevo aos elementos da narrativa, cujo sentido mitiga ou contradiz o discurso utópico da «ordenação» e da instituição dessa ordem. Entre esses elementos, o facto de o herói ceder ao furor $^{59}$, em virtude da amicitia que o liga a Palante, e de dar morte a um submetido implica, nas leituras pessimistas, obliterar a ideia de

${ }^{57}$ Gladiator de Ridley Scott, 2000.

${ }^{58}$ Em Portugal, vide os contributos de Medeiros (1992), Pereira (1992) e André (1992).

${ }^{59}$ Galinsky (1988) 333-334 justifica ofuror de Eneias: «In the final scene, Aeneas' behaviour is almost a textbook illustration of Aristotle's view of anger. Aristotle nowhere says that it is always wrong to be extremely angry nor is anger the result of some totally irrational force. (....) In short, in respect to anger we have excess, deficiency, and the observance of the mean (NE 1108a4). The three characters of the Aeneid which are in complete conformity with these categories are, respectively, Turnus, Latinus and Aeneas.» 
que, subjacente à Eneida, existe um propósito de exaltação e de celebração do império e do seu imperador.

Aceitar a propriedade destas constatações não implica, do nosso ponto de vista, aceitar necessariamente a ideia de que a Eneida traduz uma crítica a Augusto e às suas políticas ${ }^{60}$. Com efeito, a análise substantiva da Eneida implica lê-la, tendo em conta os seus planos, que são múltiplos e evidenciam múltiplas sensibilidades. Virgílio desenvolvera já quadros em que a tragicidade da História surge como elemento central. Ao apresentar Marcelo, no catálogo dos heróis do canto VI, o jovem filho de Octávia e sobrinho do imperador, que possivelmente sucederia a Augusto não fosse a circunstância da sua morte prematura, o valor optimista, associado a esse catálogo enquanto metonímia da grandeza do império, não deixa de revelar a sua primeira fractura, por meio da demonstração de que a consecução «ética e ideológica de um ideal histórico e a sua forçosa resolução em um plano humano se faz sempre no quadro de um equilíbrio precário, que resulta do facto de nessa resolução interferirem contingências e fatalidades, ou seja, factores externos ao plano humano e relativamente aos quais o homem não tem capacidade de acção e modificação.» ${ }^{61}$ Figuras como Dido, Marcelo, Palinuro, Niso e Euríalo, entre muitas outras, constituem exemplos ilustrativos do peso que a indeterminação e a fragilidade humana têm na consecução do plano histórico. E a última acção de Eneias parece dar continuidade a este sentido, demonstrando que a tragédia da História é sempre uma faceta da própria História - elemento que, embora não deixe de se constituir como uma forte mitigação do carácter optimista associado a qualquer processo histórico, não anula, contudo, a Cidade, que se anuncia ao longo de doze livros, nem o seu projecto.

${ }^{60}$ Wilson (1969) 74-75 observa: «To my own mind, a conscious anti-Augustanism in Virgil (....) is quite unacceptable. The systematic blackening of Turnus' character in itself goes against such a view. And yet, in spite of Virgil's efforts, Turnus survives his moral blackening and the foul forces of death to emerge as an authentic hero while Aeneas, by his very good intentions, is ultimately an ineffectual sentimentalist who in the name of humanitas ravages the pristine Italian world just as he had ravaged the budding city of Carthage.» Putnam (1987) 193 considera que o não cumprimento dos preceitos de Anquises «(....) means that Aeneas' final deed of killing his arch enemy Turnus is the first truly Roman action - Aeneas as Romanus, not Troianus. That he disobeys his father's exhortation to practice clemency and, in the heat of fury, kills a suppliant as the epic ends, therefore calls into question both the hero's much touted pietas and the possibility of any higher morality in the Roman design for rule. He is, finally, a spiritual failure in both the private and the public spheres, but the consequences at the end of the epic are far larger than in the aftermath of the Dido interlude. Aeneas' final act demeans both father and son, and darkens the Roman future, at least as Virgil envisions it.»

${ }^{61}$ Teixeira (2007a) 194. 


\title{
Horácio e Roma: \\ UM POETA E UMA CIDADE EM CONSTANTE RENOVAÇÃO.
}

\author{
Pedro Braga Falcão \\ Universidade Católica \\ Centro de Estudos Clássicos
}

Alme Sol, curru nitido diem qui promis et celas aliusque et idem nasceris, possis nibil urbe Roma

uisere maius.

Almo Sol, que em teu refulgente carro o dia fazes surgir e escondes, e que um outro embora o mesmo sempre renasces, possas tu nada maior ver do que a urbe de Roma. Horácio, Cântico Secular (Carmen Saeculare), 9-12

Não há talvez versos mais elucidativos acerca da relação de Horácio com a sua cidade, Roma, do que estes que acabámos de citar. Não só, obviamente, pelo seu conteúdo - uma súplica e um desejo acerca de uma eterna hegemonia da Vrbsmas fundamentalmente pelo contexto poético, histórico e até musical em que estes versos foram produzidos. Para o compreendermos, teremos obrigatoriamente de viajar no tempo, mais precisamente para o ano 17 a.C.. Estamos a 3 de Junho, na manhã que sucede a três noites e dois dias (depois de muitos outros de intensa preparação) de uma festividade apoteótica que envolveu o sacrifício de mais de uma dezena de animais, entre cordeiras, cabras, bois e vacas, e a consagração de mais de meia centena de bolos sagrados, um faustoso e dispendioso ritual público pontuado por diversos jogos (cénicos e circenses), e banquetes em honra de divindades femininas (sellisternia), dados por 110 matronas romanas. Nesse dia, que podemos adivinhar luminoso, no Monte Palatino e com gestos seguramente solenes, Augusto e o seu lugar-tenente Agripa dirigem-se numa prece ritual a Apolo e a Diana: a mesma prece é dirigida ao deus, e repetida à deusa. Os seus rogos são sensivelmente os mesmos que se ouviram nos três dias anteriores; de todos, uma frase se salienta - toda a comunidade romana a escuta de forma especial: "suplico e peço-te que sempre faças crescer o poder e a majestade do povo romano na guerra e na paz" (uos quaeso precorque uti imperium maiestatemque p(opuli) R(omani)] Quiritium duelli domique au[xitis, CIL, VI, p. 3237, n. 32323, 1. 94). Pouco tempo depois, de novo no Monte Capitolino, Roma vê surgir um coro de 27 raparigas e 27 rapazes. Um pormenor talvez lhes escape a atenção, ou quem sabe alguém no público tenha reparado nisso: todos esses jovens têm ainda os pais e as mães vivos. As suas vozes ecoam na encosta, e no primeiro fôlego musical do coro dois nomes surgem: Apolo e Diana. "Quem 
terá composto o cântico?” - perguntar-se-á alguém curioso. O cidadão mais bem informado com certeza lhe dirá - "foi Quinto Horácio Flaco". Pouco depois, no Capitólio, o mesmo cântico é entoado.

Mas como sabemos nós tantos pormenores acerca deste acontecimento particular? Ao contrário de outros acontecimentos históricos ou religiosos de Roma, a narração não nos é dada por um historiador ou por algum manuscrito milagrosamente retransmitido ao longo de vorazes milénios: foi gravado na pedra um relato preciso e altamente pormenorizado de todos os preparativos, do ritual em si e até do que aconteceu depois destes Ludi Saeculares, estes "Jogos Seculares" mandados celebrar por Augusto, ecos de uma longa tradição, cuja data mais antiga podemos apontar com alguma segurança: 249 a.C.. Jogos em que se celebrava o poderio romano e se suplicava por mais um saeculum (100 ou 110 anos, segundo o entendimento de cada geração) de vitórias e prosperidade. $\mathrm{Na}$ verdade, este relato, inscrito para sempre na face fria do mármore, só foi descoberto em 1890 - mais precisamente quando se construía a ponte Vittorio Emanuele II, por ironia dedicada ao primeiro rei de uma Itália pela primeira vez unida. Mesmo um leitor com pouco traquejo ao nível da descodificação de inscrições, se olhar com atenção para este vestígio único e inestimável do passado, decerto adivinhará, sensivelmente a meio, um nome bem conhecido, e que o mundo aprenderia a admirar.

Com efeito, é sempre com emoção que um leitor e um estudioso de literatura lê, inscrito num documento com mais de dois milénios, um nome que sempre vira impresso, que tomara como o eco remoto, uma espécie de abstração ontológica de alguém que de facto nasceu, viveu e morreu. Aqui não. Um homem contemporâneo deste poeta esculpiu com o seu cinzel esta extraordinária frase, que acaba por descrever de uma forma talvez mais intensa do que qualquer outra, a relação de Horácio com a sua cidade: carmen composuit Quintus Horatius Flaccus: Quinto Horácio Flaco compôs o cântico, a ode, o carme, a música. Cântico este que, juntamente com toda a sua obra, durante séculos nos fora transmitido pelo punho de gerações e gerações de seus admiradores e estudiosos - um carmen tal como tantos outros conservados nos seus quatro livros de Carmina. É dos poucos casos, na Antiguidade, em que uma obra literária se encontra de uma forma tão autêntica com a História - todas as peças se completam e dão-nos um exacto relato de como um poeta viveu o seu momento, o seu kairos, a sua oportunidade na cidade das cidades. Mas que momento foi este?

Poucos poetas antigos nos deixaram um relato tão pormenorizado da sua vida como Horácio, em muitos sentidos o primeiro autor a deixar escrita grande parte da sua biografia. Imagine-se que a partir da sua obra (cf. C. III.21.1.67 e Ep. I.20.26-27) se pode até reconstituir o mês e o ano em que nasceu: 
Dezembro de 65 a.C. ${ }^{1}$. Tomando por princípio que é o próprio vate quem nos convoca a conhecer a sua vida e as relações que estabeleceu com as principais figuras da cena política e social romana do seu tempo - não nos esqueçamos dos nomes de Augusto, Mecenas, Agripa, entre tantos outros, espalhados por toda a sua obra - façamos o esforço de nos concentrar sumariamente nos seus textos, para tentar reconstituir em que momento histórico Horácio se insere, como forma de percebermos a relação simbiótica deste poeta com a sua cidade. Comecemos com uma das suas primeiras odes (I.2), com um início (iam satis terris niuis atque dirae / grandinis misit Pater) que, a um leitor desatento, pode passar despercebido: fala-se acerca de uma série de calamidades que se abateram sobre Roma, de uma intempérie, de um rio Tibre indomável no seu leito, precipitando-se sobre o templo de Vesta no Fórum. E uma expressão fica no ouvido: iam satis, "já bastante", "já assaz" - algo que pressupõe que "já chega”. A leitura que possamos fazer destes sinais da natureza tem uma forte componente metafórica: descreve-se um cenário calamitoso, que prepara o caminho para duas estrofes centrais pessimistas, focadas na realidade do passado recente romano:

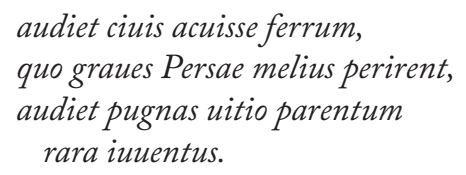

quem uocet diuum populus ruentis imperi rebus? (...) (C.1.2.21-26

A juventude, por vício paterno enrarecida, ouvirá que os cidadãos afiaram a espada sobre a qual melhor teriam os terríveis Persas perecido, e ouvirá o relato de outras guerras.

Por qual dos deuses poderá clamar o povo perante a ruína do nosso império? (...)

O sujeito rara iuuentus tem uma interpretação literal: a juventude tornou-se rara, de facto, no meio de tanta mortandade causada por um contínuo de guerras e batalhas fratricidas. E de facto Horácio não exagera: nesse último saeculum vivera-se em Roma a guerra contra Jugurta (111-105 a.C.), a guerra social (91-88), a guerra civil entre Mário e Sula (88-82), a revolta dos escravos (73-71), o assassinato de Pompeio após Farsalo (48), o assassinato

\footnotetext{
${ }^{1} \mathrm{O}$ dia (8 de Dezembro) é dado por Suetónio (Vita 63).
} 
de César (44), a derrota de Bruto e Cássio em Filipos (42), e a guerra civil entre Octaviano e António, que praticamente acaba em Áccio (31). A data presumível para a escrita desta ode - não depois de 30 a.C. (Nisbet e Hubbard 1970 17-19) - coincide pois com o fim de um dos períodos mais sangrentos da História de Roma. O poeta dá voz a um sentimento sincero de todo o povo romano: o de horror, perante a sucessão de infindáveis guerras civis que tanta desgraça e miséria causaram, sendo que nem sempre foi fácil perceber quem tinha afinal razão - lutas entre grandes personagens antagonistas, que movimentavam consigo um enorme contingente de homens, fazendo lutar acerrimamente facções que, muitas vezes, no ano anterior tinham sido amigas e viviam em paz. E não é só o fratricídio que Horácio condena: na expressão "Persas" o vate relembra ao ouvinte romano uma outra cicatriz bem aberta - a da catástrofe sofrida em Carras pelo exército de Crasso: em Junho de 53 a.C., um contingente importante do exército romano comandado por Crasso, na ânsia de controlar as rotas comerciais com o Extremo Oriente, foi completamente dizimado pelo exército parto em Carras. Daqui resultou a morte de 20 mil soldados, entre eles o procônsul, 10 mil prisioneiros, e a perda das insígnias do exército, só recuperadas diplomaticamente no tempo de Augusto. Esta foi uma humilhação de que os Romanos nunca mais se esqueceriam - e que Horácio faz questão de relembrar na sua hiperbólica referência aos "Persas".

É sempre difícil avaliar até que ponto é verdadeiro ou retórico o sentimento de um poeta posto em verso, sobretudo no mundo clássico, em que a técnica composicional era levada a um extremo que talvez nenhum outro contexto literário conheça. Mais do que consultar a opinião dos inúmeros estudiosos que têm vindo a comentar e a analisar a obra de Horácio - em que, no nosso entender, o estudo geral de Fraenkel (1957) continua a ser uma referência segura - importa mais do que tudo ouvirmos o poeta e acreditarmos - ou não - na sinceridade das suas palavras. Muito se discute acerca de uma suposta macroestrutura das odes; o único dado seguro que temos, porém, é que Horácio deu ao início e ao fim dos seus livros um lugar de claro e inequívoco relevo. Por exemplo, a primeira ode do Livro I começa com a invocação de Mecenas, o protector e amigo imortal do vate romano, e o Livro III acaba numa apoteose do poeta e da sua poesia - o famosíssimo exegi monumentum. Porque falamos nisto? Porque a primeira ode do segundo livro tem um dos momentos mais emocionais da obra de Horácio (muitas vezes contida demais para o gosto contemporâneo), colocado propositadamente no início de um novo livro de odes, facto que comenta a importância que o próprio poeta atribuiu à composição em particular; a ode é um longo crescendo, que tem um movimento dinâmico violento sensivelmente a meio: 
testatur auditumque Medis

Hesperiae sonitum ruinae? Qui

gurges aut quae fumina lugubris

ignara belli? Quod mare Dauniae

non decolorauere caedes?

Quae caret ora cruore nostro?

(C. II.1.29-36)

Que campo não engordou com o sangue latino, que campo não testemunhou, com seus túmulos, ímpios combates, que campo não experimentou o estrondo da ruína da Hespéria, ouvido pelos próprios Medos?

Que marítimos abismos ou que rios ignoram esta lúgubre guerra? Que mar não foi manchado pelo massacre dos Dáunios?

Que costa não está suja com o nosso sangue?

As imagens a que o poeta recorre são fortíssimas, e não deixariam com certeza nenhum romano indiferente, especialmente aqueles que, anos antes, por pouco salvaram a vida numa batalha como a de Filipos (42 a.C.) - alguém precisamente como Horácio, que combatera ao lado de Bruto e Cássio, os últimos dos republicanos, contra - imagine-se(!) - Marco António e Octaviano, este último que viria a tornar-se o princeps César Augusto. A relação de Horácio com o passado recente da sua Roma é ambígua e traumática, e sempre que o autor fala nele, particularmente nas odes, o ouvinte acaba por se aperceber disso mesmo. Os combates ímpios (impia proelia) e a imagem de um campo que engorda com uma matança civil, o terrível retrato de um mar sujo com o sangue romano, todas estas hipérboles traduzem estilisticamente um horror e uma vergonha que não nos parece em nada retórica - precisamente porque, a partir de outros textos horacianos, sabemos que Horácio participou em primeira mão em alguns dos eventos traumáticos de Roma, ou pelo menos esteve bastante perto de quem os viveu. Na Ode II.7, ou em III.4.25-28, por exemplo, o poeta fala da sua participação na batalha de Filipos - embora em moldes assaz irónicos, quem sabe como nota de rodapé para Augusto, afirmando a sua indiferença perante os erros da juventude. Mas mesmo a infância de Horácio foi provavelmente condicionada pela difícil circunstância política da Urbe: sabemos, por exemplo, a partir de uma das suas Sátiras (I.6.45-47), que o seu pai era um liberto. Os estudiosos (Williams 1995 296-313) especulam o motivo pelo qual o pai foi escravo: talvez tenha sido feito cativo na guerra social, que, entre 91 a 88 a.C., opôs os antigos aliados de Roma à própria cidade. Talvez tenha sido escravo por pouco tempo, cativo de guerra, e tenha 
sido liberto pouco tempo depois. Mas nem por isso deixa de ser um liberto, algo que tem uma forte conotação no contexto romano - e que certamente fez com que Horácio, desde novo, se apercebesse do difícil kairos em que nasceu, tendo presenciado ao longo de toda a sua infância e juventude aquilo que viria a descrever numa das suas odes como a forte "agitação civil" (motum ciuicum, II.1.1) que tomou conta de Roma durante tanto tempo.

Por isso mesmo devemos ter algum cuidado quando julgamos a forma subserviente, como diriam alguns, como o poeta romano lidou com a figura central da cena política romana do seu tempo; falamos, naturalmente, de César Augusto. De facto, foi este homem que, de uma forma decerto autocrática e violenta, pôs fim a todo o processo de degradação política que colocaria inexoravelmente Roma na rota da destruição. De facto, um império tão grande não poderia sobreviver a mais um século de lutas e divisões internas (ainda que em parte Augusto tivesse sido um dos responsáveis pela última destas) - algo que é precisamente apontado como uma das principais causas da queda do império romano do ocidente, cerca de seis séculos depois de Horácio nascer. E mal ou bem, Augusto trouxe de novo a paz aos Romanos, não só com as suas amnistias políticas, com as suas "simpáticas" expropriações de terras para abonar os soldados cansados da milícia, enfim, com toda aquela "propaganda de regime", como diríamos hoje, presente na expressão pax augustana, mas também com as suas minuciosas perseguições, controlo rigoroso do Senado e das instituições da república, feito de modo tão hábil e subtil que poucos se aperceberam disso, e os que se aperceberam, ou não o disseram ou morreram.

Horácio, não há como negá-lo, esteve do lado do princeps. Naturalmente, sendo um homem de carne e osso, este apoio não foi nem constante nem sempre presente - não nos esqueçamos de que estamos perante dois homens verdadeiramente contemporâneos: Horácio nasce a 65 a.C., Octávio a 63 a.C., filho de um modesto senador, e os dois tiveram de fazer a sua carreira, uma literária, a outra política, a pulso, já que não nasceram no seio de famílias poderosas. Isto levou a que, em certos momentos das suas vidas, ambos ocupassem facções antagónicas. Já aqui dissemos, por exemplo, que na batalha de Filipos o poeta combateu do lado de Bruto, um dos assassinos de César (pai adoptivo de Octaviano, que viria a chamar-se Augusto), e fez questão de o afirmar algumas vezes na sua obra (cf. C. II.7.9-12, III.3.4.25-28, Ep. II.2.49-54) . Por outro lado, no Livro I das Sátiras (35 ou 34 a.C. $)^{2}$ e no Livro II das Sátiras e nos Epodos (30 a.C.), Augusto (a quem chama simplesmente César) está pouco presente, quando comparado com o resto da sua produção poética - as Odes e as Epistolas, escritas bastante tempo depois. Ainda assim,

${ }^{2}$ Para um bom apanhado do estado da questão actual sobre a biografia de Horácio e a cronologia da sua obra, cf. Nisbet (2007 7-21). 
mesmo nas odes com uma data de composição presumivelmente mais recuada, como por exemplo a famosa ode I.37 (Nunc est bibendum, celebração da batalha de Áccio, em 31 a.C., que consolidou definitivamente o poder do princeps), embora surgindo César Augusto num contexto laudatório, o tom é ainda algo ambíguo e velado - neste poema, por exemplo, acaba por enaltecer-se a coragem daquela que deveria ser, segundo a propaganda augustana, uma das inimigas figadais de Roma: Cleópatra - uma desprotegida e iludida pomba à mercê de um temível falcão. Que diferença há entre esta ode e uma outra como IV.3, escrita seguramente mais de quinze anos depois, cujas estrofes finais (em particular 41-52) louvam de uma forma apoteótica, quase religiosa, um ansiado regresso de Augusto (chamado assim mesmo, e não "César" como em outras odes) de uma arrastada campanha na Gália... Numa das últimas epístolas de Horácio, o poeta chega mesmo a afirmar peremptoriamente a divindade de César Augusto:

praesenti tibi maturos largimur honores
iurandasque tuum per numen ponimus aras,
nil oriturum alias, nil ortum tale fatentes.

É na tua presença, contudo, que agora ainda a tempo te honramos, construindo altares onde juramos pela tua divindade, admitindo que nada semelhante a ti há-de nascer ou nasceu.

(Ep. II.1.15-17)

O que mudou, contudo, em Horácio? Fundamentalmente, ter entrado no reservado círculo de Augusto. Aqui, teremos necessariamente que falar em Mecenas, conselheiro pessoal de Augusto e um dos seus primeiros e mais fiéis apoiantes. Foi ele quem congregou à sua volta nomes-chave para a literatura da época, como P. Tuca, Vário Rufo, Domício Marso, ou, mais relevantemente ainda, um outro grande nome da literatura latina: Vergílio. Só com o apoio económico de Mecenas, nomeadamente quando este oferta a Horácio uma propriedade na Sabina, o poeta consegue desenvolver a sua actividade literária livre das preocupações de quem tem de procurar constantemente um meio de subsistência. Naturalmente, este apoio teve um custo - segundo alguns - ou um benefício extra - segundo outros: a convivência com o princeps de Roma. Segundo uma biografia resumida de Horácio (a chamada Vita Horatii) epítome de uma mais abrangente, hoje perdida, do famoso biógrafo Suetónio, que tinha acesso privilegiado à documentação imperial - sabemos que o poeta e Augusto tinham uma relação próxima, mas não tão de dependência como se poderia julgar. De facto, Horácio chegou a recusar um cargo como secretário do princeps, que estava cansado de escrever as cartas por seu punho. Tal recusa não foi interpretada como uma afronta, antes o próprio Augusto 
acaba por tentar "reconquistar" a amizade de Horácio, dizendo-lhe, numa carta conservada nesta biografia, algo como "ainda que sejas tão orgulhoso a ponto de desdenhar da minha amizade, eu não te retribuirei na mesma moeda..." (neque enim si tu superbus amicitiam nostram spreuisti, ideo nos quoque

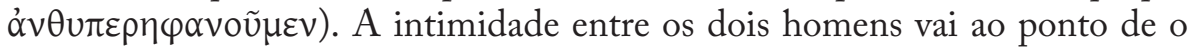
princeps se referir afectuosamente a Horácio como o seu "puríssimo rapazinho" (penis purissimus ${ }^{3}$ ) ou "elegantíssimo homenzinho" (bomuncio lepidissimus), fazendo referência à baixa estatura do poeta.

Não nos afastemos demasiado, porém, da questão principal, que tem a ver com a relação entre Horácio e a sua cidade. Isto porque, para entendermos o porquê desta ligação complexa entre o poeta e Augusto, temos necessariamente também de compreender o papel que Horácio a si próprio atribui no destino da sua Roma. E para isso, voltamos ao Carmen saeculare, com que iniciámos este texto. Poucos se apercebem, ao ler este poema, que o número três está omnipresente ${ }^{4}$. Por exemplo, cada parte é composta por três conjuntos de três estrofes (tríades) e, literalmente, o número 3 surge no verso 23, e o 9 igualmente no verso 62. Cada estrofe invoca igualmente três divindades (ou epítetos de divindade) ou conjuntos de três. Isto porque os Jogos que Augusto organizou para celebrar religiosamente uma nova ordem em Roma se organizaram, precisamente, em torno do número três. Durante estes três dias, são feitos três sacrifícios respectivamente em honra de Júpiter, de Juno, e de Apolo e Diana, os deuses luminosos. Durante estas três noites, são feitos três sacrifícios respectivamente em honra das Moiras, das Ilitias e de Terra Mater, divindades mais sombrias, ctónicas. Na primeira noite são sacrificados nove cordeiras e nove cabras. $\mathrm{Na}$ segunda noite e no terceiro dia, são consagrados nove bolos sagrados de três variedades. Os rituais sem derramamento de sangue ocorrem em posições idênticas baseadas em ciclos de três: respectivamente no último dia de cada três cerimónias. Este é só um pequeno exemplo daquilo que se pode concluir, em termos numerológicos, da análise das Actas dos Ludi Saeculares. Mas que tem a ver isto com o poeta e a sua cidade?

Foi Augusto quem deu a Horácio o papel de vate, de poeta sagrado, no culminar de toda esta apoteótica celebração, honra que este último jamais esquecerá, e que, com a sua característica vaidade, celebrará numa das últimas odes (IV.6.41-44). Mas Horácio não interpretou levianamente o seu papel. Escondido no cântico, imperceptível, subliminar, estava na realidade um texto mágico, pleno daquela "magia ritual", na feliz expressão de Putnam (2000). Os seus versos fizeram parte daquele momento de Roma, tal como as ruas que

\footnotetext{
${ }^{3}$ A referência ao membro viril é uma alusão meiga aos meninos imberbes, usada em tom de familiaridade (cf. Fraenkel 195719 4n).

${ }^{4}$ Para uma argumentação nesse sentido, cf. Falcão 2006 77-85 e 2010 187-205.
} 
o coro de 54 jovens romanos calcorreou até chegar ao Capitólio - o momento em que o número três se associava a uma mudança profunda de paradigma - da noite para o dia, das trevas para a luz, da guerra civil para a paz augustana. $\mathrm{O}$ Carmen saeculare, pelo seu vocabulário luminoso, pela seu movimento poético e composicional da súplica à confirmação, pela sua organização numerológica, resulta como que numa sagrada anti-escatologia de Roma, naquilo que de mais palpável e simultaneamente imaterial um poeta poderia oferecer à sua cidade. Quando Horácio fechou os olhos pela última vez, se pensou em Roma, provavelmente viu-se a 3 de Junho, celebrando o dia em que, sob a égide de um homem bem conhecido seu, a sua cidade encerrava um dos capítulos mais traumáticos da sua História, que ele viveu em primeira mão. Não devemos pois ser demasiado duros na forma como julgamos esta relação subserviente entre poesia e política - é porventura mais útil falar precisamente na relação entre o poeta e a sua polis. Apesar de tudo, e além de um tal poeta não precisar da nossa defesa, também é verdade que se Horácio se tornou famoso não foi pelas suas odes políticas, mas por aquelas em que se celebra a vida, o amor, o vinho e a poesia.

Precisamente a propósito deste aspecto gostaríamos de terminar esta breve análise da relação de Horácio com Roma num outro sentido, menos político. Falámos aqui no último sopro de vida deste poeta. Dissemos que talvez o poeta tenha pensado em Roma. Ou talvez não. De facto, muitas das principais atracções desta magnífica urbe com quase um milhão de habitantes foram constantemente citadas por Horácio - o Fórum, o Campo de Marte, o Capitólio, o Tibre (Palombi 1996534 e ss.). Mas, na verdade, o poeta não nasceu em Roma - o próprio nos diz numas das suas Sátiras (II.1.34-35): "sou lucano ou apúlio / pois o colono da Venúsia lavra a fronteira das duas regiões”. Nasceu portanto na Venúsia, bem a sul da Itália, na fronteira entre a Lucânia e a Apúlia, terra que o viu nascer para a poesia, e que o poeta recorda com precisão numa ode (III.4.9-20). Ainda menino, pois o pai não queria que fosse educado numa daquelas escolas rústicas para os rudes filhos dos centuriões (S. I.6.71-78), foi estudar para Roma. Mas a ideia de um campo aprazível, longe da confusão cosmopolita da capital do mundo conhecido, ficou sempre indelevelmente impressa na mente de um poeta que, mais do que tudo, deveria apreciar o seu bom copo de vinho e a calma de um bom livro. Daí que, ao falarmos sobre as relações entre o poeta e a sua cidade, seria inexacto não referirmos que talvez Horácio não estivesse assim tão emocionalmente ligado ao espaço físico de Roma. Estamos a falar, naturalmente, não da Vrbs Aeterna, vista de um prisma político, símbolo da majestade de todos aqueles que se sentiam Romanos, mas de Roma e dos seus cheiros, das suas ruas, da sua sintomática falta de sossego, enfim, de tudo aquilo que ainda hoje torna as nossas cidades sítios pouco tranquilos e nos cansam até ao limite das nossas 
forças - uma cidade que Horácio conhecia intimamente, tendo-nos até deixado algo semelhante a um itinerário numa das suas Sátiras (I.9). E não há razão nenhuma para considerarmos retórico ou pouco sincero o desejo que o próprio poeta expressa numa das suas odes:

\section{Tibur Argeo positum colono \\ sit meae sedes utinam senectae, \\ sit modus lasso maris et uiarum militiaeque!}

(C. II.6.5-8)

Tomara que Tíbur, fundado pelo colono argivo, a última morada seja da minha velhice.

Para mim, que estou cansado, que seja o fim dos mares, das estradas, das guerras!

Tíbur, actualmente Tivoli, vila vizinha de Roma, representa noutras odes horacianas (cf. particularmente I.7) o paradigma da localidade calma e amena, que convida ao famoso carpe diem - expressão aliás cunhada por Horácio numa das suas odes (I.11.8). Numa outra epístola (I.7.44-45), Horácio chega mesmo a afirmar: "ao pequeno convêm pequenas coisas: já não é a régia Roma / quem me seduz, mas o sossegado Tíbur ou o pacífico Tarento" (mibi iam non regia Roma, / sed uacuum Tibur placet aut inbelle Tarentum). A luxúria do estilo de vida citadino, os excessos de mundanidade, a afectação ridícula de muitos dos habitantes de Roma é muitas vezes criticada pelo próprio poeta, que sugere, em troca, o decantar o vinho e o pôr de lado todos os pequenos problemas que doentiamente tomam conta dos nossos dias. E é num sítio como este - Tíbur - que o poeta deseja passar a sua tranquila velhice:

Ille te mecum locus et beatae postulant arces; ibi tu calentem debita sparges lacrima fauillam uatis amici.

(C. II.6.21-24)

Este lugar e estas ditosas colinas por mim e por ti chamam; aí com lágrima devida a quente cinza espargirás do teu amigo poeta.

Que homem é este que, confesso admirador da majestade de Roma, ao mesmo tempo quer morrer longe dela? É também isto que tornou Horácio um dos poetas mais lidos da História: um autor sempre fértil nestas felizes 
incoerências - o mesmo poeta que canta a inexorabilidade da morte, no momento seguinte se aponta a si próprio como exemplo de imortalidade. Por um lado, temos o poeta do Carmen saeculare, artífice de um rito mágico de entrega do vate ao momento da sua Roma, por outro temos o poeta do carpe diem, que recusa um lugar na corte de Augusto, que escarnece do seu passado republicano e que quer passar a velhice bem longe da Vrbs. É de facto uma das grandezas da poesia poder ser um poeta diferente a cada verso, e poder assustar a humanidade com aquilo que de mais livre o ser humano tem: a sua incongruência. E Horácio é de facto, nesse sentido, um grande poeta. 


\title{
Tibulo, o Elegíaco da RoMANidAdE
}

\author{
Luís Manuel Gaspar Cerqueira \\ Universidade de Lisboa \\ Centro de Estudos Clássicos
}

"Só a obra sobra, o resto soçobra", disse um poeta. E a biografia dos poetas decanta-se e cristaliza-se nos seus versos, na quinta-essência eterna da beleza que deixam ao mundo. As circunstâncias concretas das suas vidas escoam-se no imenso fluir do tempo, as mais das vezes sem consequências muito relevantes para o entendimento da obra.

Os poucos dados que possuímos sobre a vida de Tibulo, contudo, têm quase todos relevância para o entendimento dos seus versos. Até para não levarmos a sério algumas das afirmações pretensamente biográficas do sujeito da enunciação, persona do poeta Tibulo.

A obra de Tibulo é breve: do corpus Tibullianum só os dois primeiros livros lhe pertencem, dezasseis poemas ao todo, que perfazem 1200 versos. E breve foi também a vida deste poeta, que faleceu jovem em 19 a. C., no mesmo ano que Vergílio. Um epigrama transmitido pelos manuscritos tibulianos e atribuído a Domício Marso assinala a coincidência da morte destes poetas tão diferentes e tão semelhantes:

Também a ti, Tibulo, uma morte injusta enviou ainda jovem para os Elísios Campos, como companhia de Vergílio, para que não houvesse quem chorasse com elegias os meigos amores ou cantasse com fortes versos as régias guerras. ${ }^{1}$

Esta obra breve e curta vida lograram todavia alcançar-lhe um lugar de excepção no género elegíaco, sendo considerado pelos Romanos o seu melhor poeta. A opinião de Quintiliano tem uma credibilidade alicerçada no fino gosto e sensatez do Retor, que justifica o seu apreço por Tibulo com a qualidade estilística:

"Na elegia pedimos meças aos Gregos, e para mim o autor elegíaco mais terso e elegante é Tibulo. Há quem prefira Propércio. Ovídio é mais lascivo que qualquer deles, tal como Galo é mais duro"2.

${ }^{1}$ Te quoque Vergilio comitem non aequa, Tibulle,/Mors iuvenem campos misit ad Elysios/ ne foret aut elegis molles qui fleret amores/ aut caneret forti regia bella pede.

2 Elegia quoque graecos pronocamus, cuius mibi tersus atque elegans maxime uidetur auctor Tibullus. Sunt qui Propertium malint. Ouidius utroque lasciuior sicut durior Gallus, Institutio Oratoria, X, 1, 93. 
Mas esta opinião reflecte uma sensibilidade mais geral, como se percebe pelo testemunho da brevíssima Vita integrada na tradição manuscrita, possivelmente uma versão tardia e abreviada de uma biografia tibuliana do $D e$ poetis, uma secção hoje perdida do De uiris illustribus de Suetónio:

"Este é, na opinião de muitos, o melhor dos poetas elegíacos"3.

Este apreço é ainda reiterado por Ovídio num comovente poema sobre a sua morte. A "chorosa elegia" retoma a sua origem fúnebre, pois o "seu poeta", "a fonte do seu prestígio", arde numa pira ${ }^{4}$.

As razões deste apreço generalizado não são apenas estilísticas, como veremos.

Devo dizer que, se houve críticos modernos que questionaram esta primazia, nomeadamente no séc. XIX, eu estou completamente de acordo com os Antigos, e tenho de há muito Tibulo como o meu elegíaco favorito. Tento aqui perceber e explicar porquê, evidenciando as suas qualidades específicas, confrontando Tibulo com a tradição elegíaca helenística e com os seus confrades: Galo, Tibulo, Propércio e Ovídio.

Estes quatro nomes formam o cânone dos poetas elegíacos latinos, e são cronologicamente ordenados numa referência de Ovídio, que nos permite calcular a data de nascimento de Tibulo entre 60 e 55 a.C., tendo portanto falecido com cerca de 36 anos $^{5}$.

É certo que Ovídio refere apenas os poetas que se dedicaram exclusivamente ou predominantemente ao metro elegíaco, o que o faz pôr de lado Catulo, cuja importância no processo de apropriação romana da tradição alexandrina é fundamental.

O fundador da elegia romana será, então, Cornélio Galo. Os quatro livros de elegias de Galo perderam-se, à excepção de um verso, conhecido por tradição indirecta. Nos fins do séc. XX foi descoberto um papiro com nove versos de Galo parcialmente mutilados, em Qasr Ibrim, no Egipto, na bagagem de um oficial romano, e publicados em 1979. Estes versos, apesar da escassez do material, revestem-se de grande importância. Galo é o fundador da escrita elegíaca como género em Roma, e representa a charneira com a poesia elegíaca helenística. A dedicatória a Galo por parte do grego Parténio, último

\footnotetext{
${ }^{3}$ hic multorum iudicio principem inter elegiographos obtinet locu, Vita.

${ }^{4}$ Memnona si mater, mater plorauit Achillem, / et tangunt magnas tristia fata deas, / flebilis indignos, Elegia, solue capillos!/ a, nimis ex uero nunc tibi nomen erit/ille tui uates operis, tua fama, Tibullus/ardet in extructo, corpus inane, rogo. Amores, III, 9.

${ }^{5}$ Vergilium uidi tantum, nec auara Tibullo/ tempus amicitiae fata dedere meae./ successor fuit hic tibi, Galle, Propertius illi; / quartus ab his serie temporis ipse fui. Tristia, IV, 10.
} 
grande elegista da escola alexandrina, da sua obra Erotika pathemata, antologia em prosa de histórias mitológicas coligidas a partir dos poetas helenísticos, faz conjecturar uma proximidade temática e estilística com os poemas narrativos de carácter mitológico, tanto mais que os mitos desta se destinavam a propiciar material de trabalho a Galo.

Acresce a esta filiação que uma das poucas coisas que se sabem de Eufórion de Cálcis é o facto de as suas elegias terem sido imitadas por Galo e pelos elegistas subsequentes, segundo o gramático Diomedes ${ }^{6}$, que refere também Calímaco como fonte.

Por outro lado, nos fragmentos do "novo Galo" a amada surge como fonte da infelicidade do poeta e é chamada domina, introduzindo a temática do seruitium amoris e revelando a dimensão pessoal da sua poesia.

Adivinham-se, pois, em Galo, traços da herança elegíaca grega e elementos confessionais e temas que caracterizarão a elegia latina.

A obra de Tibulo é contudo a primeira do género em Roma que chegou integralmente até nós e nos permite aquilatar documentadamente quais os elementos resultantes da tradição e em que consiste a originalidade da elegia latina.

A distinção básica entre a tradição helenística, tanto quanto se percebe pelos fragmentos que nos chegaram, e a elegia latina consiste numa oposição entre elegia objectiva e subjectiva. Os poetas elegíacos gregos cultivaram uma elegia em que narram as experiências amorosas de personagens míticas e históricas, na terceira pessoa. Trata-se, pois, de uma elegia amorosa objectiva. Isto apesar de ocasionalmente surgirem em Calímaco monólogos em que se derrama a subjectividade do sujeito da enunciação.

A elegia romana, ao invés, explora as emoções e as vivências narradas na primeira pessoa, sendo, assim, uma elegia subjectiva. Esta dimensão pessoal encontra-se na literatura grega helenística e grega arcaica sobretudo no epigrama e representa uma evolução peculiar da elegia latina.

É certo que os poetas latinos criam personae que não coincidem com as características biográficas dos autores, e esta oposição é assim relativa, mas real, pela diferença básica que provoca no tom do género, que se torna pessoal e confessional, o que já encontramos em Galo.

A ilustrar esta ficção biográfica está o facto de Tibulo falar recorrentemente da sua paupertas, contudo na Vita o poeta é dado como eques Romanus, estatuto que partilha com os outros três elegíacos da lista ovidiana, o que implica um desafogo económico, isto apesar dos estragos que a guerra civil possa ter

${ }^{6}$ Quod genus carminis precipue scripserunt apud Romanos Propertius et Tibullus et Gallus imitati Graecos Callimachum et Euphoriona. Diomedes, Ars Grammatica.III, in Grammatici Latini, ed. Heinrich Keil, I, Georg Olms, Hildesheim, 1961, p. 484. 
causado ao seu património, o que se percebe por algumas referências na sua obra e que aliás aconteceu também com Propércio e Vergílio. A sua paupertas e as frequentes afirmações do carácter modesto do seu património têm, pois, de ser vistas de um modo muito relativo, tal como as suas invectivas contra o diues amator, pois estamos perante lugares-comuns do género.

Sabemos pelo testemunho de Horácio que era rico e bem-parecido, e que sabia viver a vida:

Álbio, de meus trabalhos literários honesto juiz, que direi que tu estarás a fazer na região do Pedo?

A escrever algo que suplante os opúsculos de Cássio de Parma ou a passear silencioso por entre as saudáveis florestas, cuidando no que é digno de um homem bom e sábio?

E tu não eras um corpo sem coração: os deuses deram-te a beleza, a riqueza os deuses te deram, e a arte de as gozar. ${ }^{7}$

Horácio aprecia nele a elevação aristocrática e a busca do que convém a um homem requintado e sábio, na rivalidade com outros poetas e no afastamento para o seu recesso campestre da região pedana, afastamento com que Horácio naturalmente se identifica.

Tibulo tem a beleza, as riquezas e a arte de as gozar. Esta imagem de um Tibulo rico e bem-parecido coincide com a Vita, que o chama de "belo e

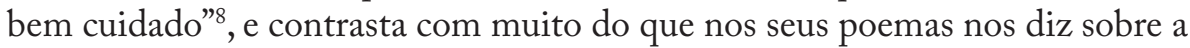
modéstia da sua condição.

Por outro lado, esta oposição elegia objectiva/subjectiva tem ainda de ser matizada, para além da questão das personae poéticas, com uma utilização ecléctica de modelos pelos elegíacos romanos, que hoje se admite, e em que a Comédia Nova e sobretudo o epigrama, veículo da subjectividade erótica, têm também de ser considerados. O epigrama em dísticos pode mesmo ser considerado uma forma reduzida do que será a elegia romana.

Catulo representa um ponto-chave nesta evolução: é ele quem faz a articulação da narrativa mitológica e da dimensão pessoal do desejo e dos afectos, tendo tido também a importância crucial de assumir uma ruptura com a tradição latina arcaica, tomando como modelos os poetas alexandrinos, o que faz dele o principal dos jovens vanguardistas a que se refere Cícero

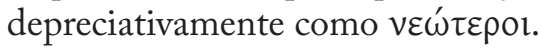

\footnotetext{
${ }^{7}$ Albi, nostrorum sermonum candide iudex,/ quid nunc te dicam facere in regione Pedana?/ Scribere quod Cassi Parmensis opuscula uincat,/an tacitum siluas inter reptare salubris, / curantem quicquid dignum sapiente bonoque est?/ Non tu corpus eras sine pectore; di tibi formam,/ di tibi diuitias dederunt artemque fruendi. Epistulae, I, 4, 1-7.

${ }^{8}$ insignis forma cultuque corporis obseruabilis.
} 
Catulo trata o mito como espelho da experiência amorosa do indivíduo, seja por contraste, seja como paradigma a seguir, e sempre com aquela exacerbada paixão catuliana, que tantas gerações impressionou. É o caso do epitalâmio de Tétis e Peleu, o poema 64, bodas em que o amor feliz manifesta a harmonia da união do humano com o divino, da deusa e do mortal, em que é encaixada por ecphrasis a triste história de Ariadne e Teseu. E Ariadne abandonada na praia de Naxos, lamentando-se de forma pungente com o seu confrangedor lamento, é também uma persona: é Catulo travestido que chora na praia de Naxos, abandonado por Lésbia.

É na sequência deste processo que surge Tibulo, em que o mito se contrai mais para dar um lugar ainda maior ao indivíduo. Propércio, assumindo-se como um Calímaco romano, representa um retrocesso nesta evolução, pois o seu material mítico é mais pesado e menos subordinado ao material subjectivo do que em Tibulo.

Outro elemento relevante da estrutura formal de Tibulo é o facto de os seus poemas se afastarem da tradição narrativa alexandrina, dando lugar a uma contemplação reflectida que se afasta do tempo narrável, criando um tempo acrónico de sonho.

Se verificarmos os tempos verbais dos poemas de Tibulo veremos uma dominância de tempos do infectum, presente e imperfeito, que manifestam esta acronia, mesmo quando fala dos tempos de antanho, de uma Roma rural e pia idealizada, que se confunde com a Idade do Ouro. Esta noção temporal de continuidade e a ausência de pretéritos perfeitos, com o seu acontecer, marca com uma serenidade nostálgica todos os seus poemas.

Em vez da narrativa encontramos o devaneio e, algo muito característico do nosso poeta, pequenos quadros idealizados, de carácter teatral, que o poeta imagina e a que dá vida com descrições de grande beleza.

Damos um exemplo: a especulação sobre a primitiva simplicidade do culto aos deuses, que corresponderia a uma maior devoção e sinceridade, facilmente evolui para a visualização de um cortejo religioso com personagens que se tornam concretas, como um quadro dramático, e do qual o poeta passa subitamente a fazer parte, acompanhando as jovens que levam as oferendas:

Então melhor preservavam a fé, quando com culto simples se erguia um deus feito de madeira num pequeno santuário, e aqui era aplacado, quer alguém fizesse libações com vinho quer tivesse oferecido uma grinalda de espigas à sua cabeleira, e alguém, tendo alcançado os seus votos levava ele próprio os bolos rituais e atrás dele a filha pequenita, acompanhando-o, levava um favo puro de mel, 
...e um porco, vítima oriunda de um aprisco repleto.

Que eu a siga com uma veste pura

e leve um cesto atado com murta,

com a minha cabeça também de murta adornada ${ }^{9}$.

Este afastamento do carácter narrativo da elegia helenística e estas peculiaridades de Tibulo, criador de pequenos quadros de carácter dramático, não podem, no entanto, fazer-nos esquecer a influência real da poesia helenística grega, manifesta em muitos lugares-comuns do género.

Propércio afirma orgulhosamente a sua relação com Mimnermo e Calímaco. Também Tibulo, embora o não professe ostensivamente, se insere nesta tradição. Temos poemas que ilustram muitos dos tópicos da poesia helenística, como o paraklausithyron, isto é, um poema diante da porta fechada, em que o poeta, exclusus amator, se confronta com a impossibilidade material de se aproximar da amada, tópico helenístico cuja longa tradição remonta a Aristófanes. Mas Tibulo dá-lhe um toque pessoal, ora amaldiçoando ora fazendo súplicas humildes a uma porta personificada:

Tem minha amada agora austero guarda, e firme a porta dura aldraba fecha.

Porta do meu amor, assim difícil, que as procelas te açoitem, e que um raio, por Júpiter lançado, te fulmine!

Dobrada a meu queixume, abre-te, porta;

mas para mim somente, e sem rangeres

nos duros gonzos, furtivamente entreaberta. ${ }^{10}$

Outra pretensão da poesia helenística era a poikilia, a variedade, e essa é abundante no nosso poeta. Em 1.7 temos os elementos de um genethliacon, ou poema de aniversário, mas também da ode heróica, do panegírico e do hino, tudo amalgamado numa unidade em que as fronteiras dos géneros se diluem, como faz Calímaco na sua Ecale.

${ }^{9}$ Tum melius tenuere fidem, cum paupere cultu/ Stabat in exigua ligneus aede deus./ Hic placatus erat, seu quis libaverat una, / Seu dederat sanctae spicea serta comae, / Atque aliquis uoti compos liba ipse ferebat/ Postque comes purum filia parua faum. [...]... Hostiaque e plena rustica porcus hara./Hanc pura cum ueste sequar myrtoque canistra/ Vincta geram, myrto uinctus et ipse caput. 1, 10,19-29. Uso uma tradução anónima de Tibulo, As elegias e os carmes de Tibullo e algumas elegias de Propercio e carmes fugitivos de Catullo, traduzidas em Portuguez por um curioso obscuro, Porto, 1912, 2a edição, que altero a meu bel-prazer, pelo encanto que nela vejo, apesar de algumas infidelidades que procuro amenizar.

${ }_{10}$ Nam posita est nostrae custodia saeua puellae,/ Clauditur et dura ianua firma sera./Ianua difficilis domini, te uerberet imber,/ Te Iouis imperio fulmina missa petant./ Ianua, iam pateas uni mibi, uicta querelis,/ Neu furtim uerso cardine aperta sones. I, 2, 5-10. 
A poikilia de Tibulo é particularmente original na forma como muda de assunto, numa associação de ideias que, sendo característica da linguagem verbal, manifesta uma lógica muito livre, a lógica do imaginário, em que a concatenação das ideias é feita por associação. Tibulo passeia-se pelas ideias e pelas emoções, sem preocupações de unidade, mas fá-lo com uma subtil naturalidade.

A reflexão sobre as benesses da paz, que permite a actividade agrícola, dá ocasião ao delinear de um pequeno quadro rústico, em que um camponês, já um pouco tocado pelo vinho, regressa a casa levando na carroça a mulher e os filhos, e procura a esposa com alguma violência, arrependendo-se de imediato da sua brutalidade, que leva à zanga dos amantes, instigada pelo brincalhão Amor, que se senta entre eles, e temos outro pequeno quadro, em que o poeta vai devaneando, para acabar uma vez mais na condenação da violência, aqui das guerras amorosas:

Do bosque a esposa e os filhos conduz na carroça o lavrador a casa, não muito sóbrio ele mesmo. Mas de Vénus

então as rixas fervem: sente a moça o cabelo arrancado e a porta entrada; da tenra face a pisadura chora.

E chora o vencedor sua louca força. Zombeteiro, o Amor na luta aguça injúrias, e lento enfim entre ambos vem sentar-se.

Ai! Tem de ferro o coração quem fere a sua amante: do céu provoca os deuses!11

O campo é o não-lugar, utopia onde se projecta um universo que nunca existiu senão nos anseios do poeta. Constituiu um dos temas fundamentais de Tibulo, como nos diz: "canto os campos, e os deuses dos campos", Rura cano, rurisque deos. $\mathrm{O}$ campo é o embrião de todas as artes ligadas à civilização, foi no campo que foi abandonada uma alimentação primitiva à base de bolota, que surgiu a construção de casas, a domesticação de animais, a construção de carroças, o cultivo de árvores de fruto, o regadio dos hortos, o fabrico do vinho, etc. ${ }^{12}$. É o espaço estruturado de uma continuidade que permite o progresso e

${ }^{11}$ Rusticus e lucoque vehit, male sobrius ipse, / Uxorem plaustro progeniemque domum./Sed Veneris tum bella calent, scissosque capillos/ Femina perfractas conqueriturque fores./ Flet teneras subtusa genas, sed uictor et ipse/ Flet sibi dementes tam ualuisse manus. / At lasciuus Amor rixae mala verba ministrat, / Inter et iratum lentus utrumque sedet./ A, lapis est ferrumque, suam quicumque puellam/ Verberat: e caelo deripit ille deos. I, 10, 50-60.

${ }^{12}$ rura cano rurisque deos. his uita magistris/desueuit querna pellere glande famem:/ illi compositis primum docuere tigillis/ exiguam uiridi fronde operire domum:/ illi etiam tauros primi docuisse 
confunde-se nesta função com as benesses da paz, que permitem a civilização, a estruturação e a continuidade:

Entretanto os campos lavre a paz: formosa curvou a paz os bois; a paz as vides alimenta, e de sumo faz inchar as uvas, que o filho beberá no copo do pai.

$\mathrm{Na}$ paz a enxada e a relha brilham, tristes do cruel guerreiro as armas a ferrugem come na penumbra. ${ }^{13}$

Esta dimensão campestre tem a ver com um ambiente literário, que encontra as suas raízes nas tendências bucólicas de Filetas e se manifesta também na Arcádia da poesia bucólica propriamente dita, como acontece com o contemporâneo Vergílio.

Mas o campo de Tibulo não é o campo dos pastores poetas, é o do antigo lavrador romano, com a sua boçalidade, mas também com a sua inocência e pureza. É o espaço alternativo à política, à ganância, à guerra. $\mathrm{O}$ espaço onde o amor não tem portas fechadas. $\mathrm{O}$ homem violento não tem lugar nele e deve antes partir para os combates. É o espaço do amor feliz, fonte de vida que se opõe também ao caminho lesto para a morte que a guerra abre. Enquanto se é jovem, convém amar, pois a velhice e a morte vêm ligeiras, e a militia amoris é a única milícia que lhe interessa:

Mas agora, que à porta meter ombros me não peja, senão que até me apraz travar-me em rixas, é que é suave o amor. Nestes combates de bom soldado e capitão me prezo.

Longe pendões e trompas!

Aos gananciosos levai a morte e o saque.

$\mathrm{Eu}$, certo no gozo dos meus bens, e descuidado, luxos desprezo, desprezando a fome..$^{14}$

E é o veemente anseio de regressar a esse tempo mítico que o poeta exprime ao protestar que ele próprio pegará na enxada e se dedicará ao duro

\footnotetext{
feruntur/ seruitium et plaustro supposuisse rotam. Itum uictus abiere feri, tum consita pomus, / tum bibit inriguas fertilis hortus aquas. II, 1, 37-44.

${ }^{13}$ Interea pax arua colat. pax candida primum/Duxit araturos sub inga curva boves, / Pax aluit uites et sucos condidit uuae,/ Funderet ut nato testa paterna merum,/ Pace bidens uomerque nitent-at tristia duri/ Militis in tenebris occupat arma situs. I, 10, 45-50.

${ }^{14}$ Nunc leuis est tractanda Venus, dum frangere postes/ Non pudet et rixas inseruisse iuuat./ Hic ego dux milesque bonus: uos, signa tubaeque, I Ite procul, cupidis uolnera ferte viris,/Ferte et opes: ego conposito securus aceruo/ Despiciam dites despiciamque famem. I, 1, 73-8.
} 
trabalho braçal dos campos:

Eu mesmo, na estação própria, as tenras vides e árvores de bons pomos, lavrador plantarei com mão perita. ${ }^{15}$

E, mais adiante,

e nem me peje alguma vez da enxada lançar mão, instigar com o aguilhão os lentos bois nem ao colo a cordeira ou as cabrinhas esquecidas da mãe trazer a casa. ${ }^{16}$

Não esperaríamos certamente ver um eques Romanus de enxada na mão. Mas este cavaleiro quer realmente afastar-se do ruído do mundo para um universo rural de pureza primitiva, que nunca terá provavelmente existido como ele o concebe, e é este profundo anseio que ele pretende exprimir, de forma metafórica.

Há, no entanto, um aspecto biográfico que deve ser tomado a sério, e se reveste da maior relevância para a compreensão da obra, a sua ligação a Messala Corvino, em cujo círculo gravitavam também Lígdamo, Sulpícia e o autor do Panegírico de Messala, cujos textos surgem na tradição manuscrita unidos aos dezasseis poemas do livro I e II de Tibulo, e que com os dois priapea e a Vita constituem o chamado Corpus Tibullianum.

Messala ocupa um lugar importante na obra de Tibulo, que acompanhou o seu patrono em campanhas militares à Aquitânia, na sequência dos combates subsequentes à batalha de Áccio, em que Messala participou, e segundo a Vida combateu bem, merecendo honras militares ${ }^{17}$.

Esta informação coincide com a afirmação do poeta na elegia sétima do livro I: o triunfo militar de Messala não foi alcançado sem o seu esforço de guerreiro, non sine me, e invoca os rios da Aquitânia como suas testemunhas.

A ti, Messala, com a coroa de louras da vitória, te levava uma biga de marfim com resplandecentes corcéis.

Mas não foi sem mim que tu conseguiste a glória!

Nos Pirenéus, Tarbela é testemunha

e as costas do Santónico Oceano,

são testemunhas do Arar a corrente,

\footnotetext{
${ }^{15}$ Ipse seram teneras maturo tempore uites/ Rusticus et facili grandia poma manu. I, 1, 7-8.

${ }_{16} \mathrm{Nec}$ tamen interdum pudeat tenuisse bidentem/ Aut stimulo tardos increpuisse boues, / Non agnamue sinu pigeat fetumue capellael Desertum oblita matre referre domum. I, 1, 29-32.

${ }_{17}$ Aquitanico bello militaribus donis donatus est.
} 
o Ródano veloz, o grande Garona, e do Líger azul os loiros Carnutos. ${ }^{18}$

E se esta acumulação de hidrónimos e topónimos nos faz pensar no muito alexandrino prazer de alardear erudição geográfica, há uma diferença substantiva e sintomática: estas terras distantes não são referidas para espantar quem delas nunca ouviu falar. O poeta esteve lá, lutou e sofreu lá. Também neste caso a objectividade alexandrina toma uma dimensão concreta e real. Tibulo como soldado não tem nada de que se envergonhar. Este dado é relevante para a sua reflexão sobre a guerra e a sua perspectiva de vida. Sabe de que fala.

Mas a sua recusa da guerra não será, para além das teorias epicuristas e do género literário, que prescreve a inertia e a nequitia, a atitude mais expectável em qualquer Romano que tivesse presenciado a sangueira e as chacinas que ocorreram entre a morte de César e a ascensão de Augusto?

Sabemos que Messala era homem de guerra, mas também um orador notável e um literato preocupado com a correcção linguística. Dele diz Séneca pai que era minucioso em todos os estudos e diligentíssimo cultor da língua latina ${ }^{19}$, e Tácito considera-o melhor do que Cícero, precisamente no estilo, que é menos empolado, mais suave que Cícero e mais doce e mais elaborado nas palavras ${ }^{20}$. Já Quintiliano lhe critica a falta de energia, elogiando-lhe o requinte $^{21}$.

Nestas apreciações vislumbra-se o neo-aticismo, com a sua preocupação com a correç̧ão gramatical e a rejeição da exuberância ciceroniana como modelo, gosto que triunfou no período augustano.

Estas opções estilísticas são partilhadas por Tibulo, com a sua aparente simplicidade e óbvia suavidade. Homem de muitas leituras, é culto e insere-se numa tradição literária helenística, sem fazer contudo alarde da sua erudição, ao invés de Propércio. Mas a sua sensibilidade delicada impele-o para um estilo próprio, de grande suavidade. É isso que atesta o testemunho de Ovídio, que o chama cultus, requintado, e de sensibilidade delicada, ingenium mite 22 .

Ao ler qualquer página de Tibulo em Latim somos impressionados pela clareza e simplicidade, mas sobretudo pela harmonia da frase, que acompanha

${ }^{18}$ At te uictrices lauros, Messalla, gerentem/ Portabat nitidis currus eburnus equis./ Non sine me est tibi partus honos: Tarbella Pyrene/ Testis et Oceani litora Santonici,/Testis Arar Rhodanusque celer magnusque Garunna,/ Carnutis et flavi caerula lympha Liger. I, 7, 7-12.

${ }_{19}$ exactissimi ingenii quidem in omni studiorum parte, sed Latini utique sermonis obseruator diligentissimus, Controuersiae, II, 4, 8.

${ }^{20}$ Cicerone mitior Coruinus et dulcior et in uerbis magis elaboratus. Dialogus de oratoribus, 18.

${ }^{21}$ At Messala nitidus et candidus et quodam modo prae ferens in dicendo nobilitatem suam, uiribus minor, X, 1, 113.

22 "Cultus", Amores, I1.15.28; 3.9.66; “ingenium mite”, Tristia, V, 1, 18. 
a harmonia do seu mundo ideal. Essa harmonia é sobretudo conseguida através de uma equilibrada utilização de aliterações, assonâncias e anáforas.

Vejamos o último verso da primeira elegia do livro primeiro. Aqui o exemplo tem mesmo de ser em Latim:

\section{Ego composito securus aceruo despiciam dites despiciam famem.}

Eu, seguro com um pecúlio composto, desprezarei os ricos e a fome desprezarei.

Temos as aliterações do $d$, as brandas nasais, as assonâncias do $i$, que ilustram a harmoniosa segurança do conforto de que se usufrui no mundo que o poeta para si imagina, sem fausto e sem carências.

A anáfora, um dos recursos de que mais se serve, tem nele uma função particular. Enquanto noutros poetas a anáfora exprime a violência das emoções, exacerbada pela iteração, e que provoca no leitor um sentimento de angústia e crispação, em Tibulo é abundantemente usada para criar uma ordem harmoniosa e plácida, uma afirmação renovada das coisas básicas que estruturam o seu universo. Esta anáfora, maioritariamente de substantivos e pronomes, é fonte de serenidade, reiterando a estruturação do seu mundo perfeito:

No campo o menino, a vez primeira, coroou de flores os antigos Lares; no campo foi também que a branca ovelha, cuidando no porvir das ternas moças, a finíssima lã despiu do corpo. ${ }^{23}$

O próprio tema fundamental da elegia amorosa, o amor, se integrará neste mundo campestre.

Cinco poemas do primeiro livro mencionam uma Délia, que Apuleio identifica com uma tal Plânia, família de que nada se sabe, a não ser que é a principal musa das elegias de Tibulo. A relação erótica aspira a uma relação mais séria, pesem embora as convenções da elegia amorosa, em que a amada não é de todo uma mulher desposável, ou porque vive com um coniux ou porque é sustentada por um diues amator ou porque tem um estatuto social baixo.

Com Délia, porém, Tibulo fantasia uma relação em que se pressente o desejo de um compromisso praticamente conjugal, por exemplo quando se imagina

${ }^{23}$ rure puer uerno primum de flore coronam/ fecit et antiquis imposuit Laribus./ rure etiam teneris curam exhibitura puellis/molle gerit tergo lucida uellus ouis .II, 1, 59-62. 
com ela na sua quinta, cujas actividades ela partilha com o poeta, completamente integrada no seu universo de rusticidade piedosa, a ser visitado por Messala, a quem a amada oferece os frutos da quinta, como verdadeira anfitriã:

Eu cultivarei os campos e junto a mim dos frutos

Délia a guarda será, quando as espigas

sob o pino do sol trilhar a eira;

das cheias dornas velará os cachos,

e o mosto, de ágeis pés manando, puro;

há-de acostumar-se a contar o gado

e a ter, brincando no fagueiro seio

o gárrulo menino há-de habituar-se

ela ao deus do colono as roxas uvas

pelas vides porá, e a fulva espiga

pela seara e pela grei oferendas:

em tudo há-de mandar, olhar por tudo,

folgando por eu nada ser em toda a casa.

Ali virá o meu Messala: pronta

e de árvores escolhidas os doces pomos

há-de trazer-lhe Délia; a herói tamanho

metendo brios em mimá-lo,

em cuidá-lo, em servi-lo e pôr-se às suas ordens,

a mesa aparelhar-lhe ela própria e as iguarias.

Isto para comigo imaginava, votos que agora

o Euro e o Noto dissipam pelos perfumada Arménia. ${ }^{24}$

O poeta anseia pela fidelidade da sua amada, e deseja ser ele a colocar portas sólidas entre ela e os seus pretendentes, recorrendo a uma vigilante rigorosa, colocando-se na situação oposta àquela que definem as regras do género para o poeta elegíaco:

Tu sê-me casta, te peço, e que, sentinela do santo pudor, Uma anciã zelosa esteja sempre sentada junto de ti. ${ }^{25}$

\footnotetext{
${ }^{24}$ Rura colam, frugumque aderit mea Delia custos,/Area dum messes sole calente teret,/ Aut mibi seruabit plenis in lintribus uuas/ Pressaque ueloci candida musta pede;/ Consuescet numerare pecus, consuescet amantis/ Garrulus in dominae ludere uerna sinu./ Illa deo sciet agricolae pro vitibus unam, / Pro segete spicas, pro grege ferre dapem./ Illa regat cunctos, illi sint omnia curae, / At iuvet in tota me nibil esse domo./ Huc ueniet Messalla meus, cui dulcia poma/ Delia selectis detrahat arboribus;/ Et tantum uenerata virum hunc sedula curet,/ Huic paret atque epulas ipsa ministra gerat./ Haec mibi fingebam, quae nunc Eurusque Notusque/ Iactat odoratos uota per Armenios. I, 5, 21-36.

${ }^{25}$ At tu casta precor maneas, sanctique pudores/ Adsideat custos sedula semper anus. I, 3, 83-4.
} 
Horácio assinala esta incongruência com as regras literárias da elegia, que correspondem de facto também a uma dolce vita dos jovens da aristocracia da época, dando conta desta originalidade de Tibulo, uma pessoa que se leva demasiado a sério e que tende a escapar do confronto com a vida, recusando-se a aceitar a ligeireza e a ausência de compromisso próprias dos amores dos poetas elegíacos, amores desencontrados que Horácio olha de longe com divertido cinismo, recomendando amores menos complicados:

Álbio, não sofras demasiados lembrando-te da cruel

Glícera nem entoes elegias tristes,

Perguntando-te, quebrada a confiança que tinhas,

Por que razão te eclipsa um mais jovem...

O amor por Ciro abrasa Licóris, conhecida

Por ter uma testa pequena, Ciro enamora-se

Da ríspida Fóloe, mas antes que Fóloe caísse no erro

De amar tal torpe adúltero,

Já as cabras montesas com os lobos da Apúlia casariam.

Assim aprouve a Vénus, que se diverte,

Cruel divertimento, a colocar jugo de ferro

Em formas e almas discordantes. ${ }^{26}$

Nestes amores mais ligeiros se contarão as referências de Tibulo a Márato, um rapazinho que figura em dois poemas, amores efébicos pouco frequentes na poesia latina, e a uma cortesã chamada Némesis.

$\mathrm{O}$ que torna Tibulo um autor querido dos seus compatriotas é, embora Quintiliano o não o diga, a sua profunda romanidade. Há nele a criação de um universo poético alternativo à realidade, em que se refugia. E, no entanto, este universo tem características fundamentais de romanidade: é a pietas de uma religião primitiva e simples, em cujos cândidos rituais se compraz, a sedução pela magia e pelas feiticeiras, as sagae, sem a crítica racionalista dos epicuristas mais militantes, é um universo bucólico que compartilha com Vergílio, mas em que não têm entrada nem a figura do princeps nem as questões políticas da época, pois o poder não cabe num mundo de simplicidade rústica, com os seus copos de madeira, a candura da religião com as suas jovens de grinaldas no cabelo, os seus camponeses um pouco tocados pelo álcool.

${ }^{26}$ Tradução de Pedro Braga Falcão, Odes, Cotovia, Lisboa, 2008, p. 112. Texto latino: Albi, ne doleas plus nimio memor/ inmitis Glycerae neu miserabilis/ descantes elegos, cur tibi iunior/laesa praeniteat fide.[...] / Insignem tenui fronte Lycorida/ Cyri torret amor, Cyrus in asperam/ declinat Pholoen. sed prius Apulis/ iungentur capreae lupis [...]quam turpi Pholoe peccet adultero. / Sic uisum Veneri, cui placet imparis/ formas atque animos sub inga aenea/ saeuo mittere cum ioco. Carmina, I, 33. 
Um universo em que a dimensão de continuidade está fundamente alicerçada na instituição familiar. É aos seus deuses Lares, junto aos pés dos quais brincou em criança, à sombra dos quais cresceu, que o poeta pede protecção contra os perigos da guerra ${ }^{27}$, ele que é “ aos combates arrastado", e a estes deuses da casa, das memórias de infância da família, que o poeta invoca, guerreiro contrariado e com medo da morte, que de forma muito física e real já pode estar na ponta dos dardos que algum inimigo traz consigo, no próprio momento da enunciação poética ${ }^{28}$. A família é protecção e é continuidade que estrutura, numa ordem que a guerra quebra e fragmenta.

Nesta "elegia da paz", há uma dimensão social que os outros elegíacos não têm. A guerra é para Tibulo não só a inimiga do amor, dos afectos, do seu universo de felicidade sonhada, mas também de um mundo real em que se estrutura a sociedade com os valores da civilização. Tem medo de morrer, o que é humano, apesar da sua valentia nas campanhas da Aquitânia, mas percebe o carácter disruptivo da guerra do ponto de vista social e a loucura que é apressar a morte, o que representa uma superação do individualismo básico dos poetas epicuristas.

E a guerra é algo que conhece de forma concreta. Mas também não invectiva os que a ela se dedicam, como o fazem os epicuristas mais militantes, como é o caso de Horácio, para quem o comerciante que afronta os perigos do mar na mira do lucro é louco, o comércio marítimo torna rico iure, com justiça, os que afrontam a ira do mar e as procelas. Ou o guerreiro que procura a morte por sua iniciativa.

Não é uma loucura, há mesmo pessoas a quem convém, e pessoas por quem o poeta tem apreço. A Messala convém o guerrear: Te decet Messalla, bellare. Mas o poeta tem outra perspectiva, sem julgar depreciativamente outras maneiras de viver a vida. E isto é senso comum, forma pouco comum da sabedoria:

Seja rico com mérito aquele que é capaz de arrostar com o furor do mar e com as tristes chuvas.

Oh, que pereça quanto de ouro há e de esmeraldas, antes que a minha amada sofra por causa das minhas viagens.

A ti fica-te bem, Messala, combater por terra e mar, para que a tua casa ostente despojos inimigos; a mim retêm-me preso os laços de uma linda rapariga e fico sentado como porteiro diante de uma porta insensível. ${ }^{29}$

${ }^{27}$ Sed patrii seruate Lares: aluistis et idem, / Cursarem uestros cum tener ante pedes. I, 10, 15-6.

${ }^{28}$ Diuitis hoc uitium est auri, nec bella fuerunt, /Faginus adstabat cum scyphus ante dapes. / Non arces, non uallus erat, somnumque petebat/Securus sparsas dux gregis inter oues. / Tunc mibi uita foret, uolgi nec tristia nossem/ Arma nec audissem corde micante tubam; / Nunc ad bella trahor, et iam quis forsitan hostis/ Haesura in nostro tela gerit latere. I, 10, 7-14.

${ }^{29}$ Sit diues iure, furorem/ Qui maris et tristes ferre potest pluuias. / O quantum est auri pereat 
Vive Tibulo num mundo inventado, mas inventado de acordo com uma sensibilidade simultaneamente delicada e conservadora, apaixonada mas tingida de uma veneração pelo mos maiorum e um senso comum que a moderam, um sentido prático, avesso aos delíquios eróticos que nele nunca são grosseiros nem obscenos, como acontece com um Catulo mais dominado pela ira e pelo ciúme, ou com a brejeirice despudorada e amoral de Ovídio, mantendo-se numa contenção que se compraz mais com o sobressalto dos amantes que vão encontro um do outro do que com o próprio acto sexual:

Furtiva perpassando em sono os guardas, a seu mando (de Cupido), sozinha, à noite a bela

Corre ao mancebo e, de temor suspensa, com os pés estuda o chão, tacteia, explora Com as cegas mãos alguém no sítio escuso Infeliz quem tal deus severo oprime! Ah, feliz, quem a Amor plácido anima. ${ }^{30}$

Há nele uma elevação. Se os elegíacos são poetas do afastamento relativamente à sociedade, Tibulo é um elegíaco em que grande parte da sociedade romana se pode ver reflectida.

Uma das razões para a guerra é a ganância, mas outras há, ponderosas: a glória de Roma, a noção de império, a relação com o poder. A literatura da época de Augusto está condicionada de modo geral pela sua relação com o poder político, e os elegíacos assumem uma atitude contrária ao main stream desta literatura oficial, com a sua exaltação do império.

O facto é que o lugar do poeta é o palácio, trata-se de uma literatura áulica. Ao círculo de Augusto e Mecenas pertencem Vergílio e Horácio, ao de Messala os oposicionistas moderados, antigos partidários de António reciclados e convertidos a um Augusto triunfante. O centro da oposição literária seria o círculo de Asínio Polião. A ligação de Tibulo a Messala é claramente pessoal, sem qualquer dimensão política, que está totalmente fora dos seus horizontes A sua única referência à política é a de II.5, em que alude a Áccio de forma indirecta: é um alívio a guerra estar resolvida, porque Apolo já pode voltar a ser apenas o deus do canto. O mesmo Apolo que Vergílio coloca no canto VIII a combater ao lado de Augusto.

potiusque smaragdi, / Quam fleat ob nostras ulla puella uias. / Te bellare decet terra, Messalla, marique, / Ut domus hostiles praeferat exuuias; / Me retinent uinctum formosae uincla puellae, / Et sedeo duras ianitor ante fores. I, 1, 49-56.

${ }^{30}$ hoc duce custodes furtim transgressa iacentes/ad iuuenem tenebris sola puella uenit/ et pedibus praetemptat iter suspensa timore, / explorat caecas cui manus ante uias. I a miseri, quos hic grauiter deus urget! at ille/ felix, cui placidus leniter adflat Amor. II, 1, 75-80. 
A ambição do império e da glória de Roma não têm cabimento no mundo sonhado de Tibulo. E nisso a sua romanidade se afasta de Vergílio. Nele também não encontramos a subserviência patriótica a que se dobra Propércio, mas também não encontramos o afrontamento concreto e prático de Ovídio, cujo choque contra a moral vigente tem contornos hedonistas muito reais nos Amores e na Ars amatoria.

A violência, ainda que patriótica, repugna-lhe. Também no seu universo elegíaco a violência do homem sobre a rapariga é banida e apostrofada, e a venalidade no amor repudiada. E esta sua tripla recusa do poder, da força e do dinheiro afastam-no inevitavelmente da realidade.

Nesta idealização de um mundo, que Tibulo sabe, no fundo, que nunca existiu, de frugalidade, piedade, probidade, de antanho, espaço onde o poeta se refugia do seu tempo e do seu lugar, mas que tem algo de profundamente romano, Tibulo aproxima-se da Idade de Ouro, velho tema que o poeta aborda em I, 10, 35-50. Esta identificação é marcada sobretudo pela ausência da guerra, no tempo mítico antes de serem inventadas as espadas, tempo em que gostaria de ter vivido.

Catulo é mais arrebatado, Propércio mais douto, Ovídio mais brejeiro, Horácio mais requintado e racional, mas nenhum tem aquela serenidade melancólica e distanciada nem a mesma capacidade de criar universos. Nenhum é tão romano nem tão humano.

Qual deles poderia ser melhor do que Tibulo para ir de companhia com Vergílio na sua última viagem para os Campos Elísios? Vergílio canta a missão civilizadora de Roma, canta a violência dos combates, mas com uma comiseração pelo sofrimento que a guerra comporta que Tibulo certamente compreenderia, canta os campos e a vida do agricultor, exprime e define a Romanidade, projectando a Idade de Ouro num futuro próximo. Tibulo olha para trás e para dentro, com a mesma piedade, o mesmo bucolismo sonhado, o mesmo apreço pelos valores ancestrais. Um preferiu o Amor, o outro a glória de Roma.

Há em Tibulo valores em que se reconhece uma Romanidade basilar, o que a meu ver explica, mais do que a sua inegável qualidade artística, a estima em que é tido pelos antigos Romanos. Encarna uma cultura.

Mas há também nele uma suave humanidade, feita de valores e atitudes fundamentais, ao arrepio das circunstâncias da literatura oficial da sua época, afirmando um pacifismo no meio da brutalidade em que teve de tomar parte, no repúdio do ruído e da sordidez da vida real, da ambição, da violência, da ganância, perspectivas de vida em que o homem comum do seu tempo, mas também o homem moderno, descrente de paraísos prometidos, se revê. É esse o seu fascínio. 


\section{DAlla CitTÀ DEgli AMORI ALlA CitTÀ CHE CREsCE: la Roma di Properzio}

Paolo Fedeli

Universidade de Bari

Una città può essere la somma dei nostri sentimenti o il riflesso dei nostri stati d'animo: per me, quella in cui ho trascorso i miei giovani anni, e che troppo presto ho lasciato ma non dimenticato, s'identifica con la nostalgia e col ricordo; Roma, invece, condensa tutto ciò che ho amato e cercato di raggiungere, Lisbona significa la tranquillità ritrovata e il rifugio dagli affanni quotidiani, Buenos Aires è la sintesi perfetta della mia esistenza, in tutti i luoghi in cui l'ho vissuta. Credo che sia così per tutti, perché una città è ben più che un luogo fisico: è la proiezione simbolica di quello che siamo o che riteniamo di essere.

Si può pensare che per i Romani del tempo di Augusto le cose si siano poste in modo diverso e che, in mancanza di validi termini di confronto, Roma sia stata il centro non solo del potere ma anche della loro vita, la somma dei loro interessi e delle loro aspirazioni; e certamente era così, anche se Atene manteneva la sua immagine di depositaria di una cultura secolare e continuava a esercitare il suo fascino, allo stesso modo delle remote città orientali, del cui splendore si favoleggiava. Se, però, si era per nascita Cispadani o Italici, il ricordo della terra d'origine sopravviveva tenace insieme all'orgogliosa consapevolezza di essere divenuti cittadini di Roma: le vicende di tutti i grandi poeti del circolo di Mecenate e quelle dello stesso Mecenate sono lì ad attestarlo.

Non ci si stupisce, quindi, nel constatare che quando l'umbro Properzio - sopiti ormai gli spiriti di ribellione nei confronti di Roma conquistatrice, che avevano caratterizzato la prima fase della sua produzione poetica (alludo, in particolare, a 1.21 e 22) - al tempo del suo terzo libro di elegie deve convincere l'amico Tullo a fare ritorno dall'Ellade a Roma, le laudes Italiae che egli celebra per allettarlo sviluppano in realtà un elogio dei mirabilia di Roma e dell'Umbria, dal Clitumno all'acqua Marcia, dal lago Albano a quello di Nemi e alla fonte Giuturna (3.22.23-26). E anche quando a distanza di anni, nel IV libro, la celebrazione della Roma di Augusto assumerà un ruolo programmatico, da essa non sarà mai disgiunto il ricordo delle proprie radici, in una perfetta fusione della patria antica con la nuova. Nella seconda parte dell'elegia introduttiva del IV libro toccherà all'astrologo Horos il compito di rievocare con accenti nostalgici la terra natale di Properzio e le vicende che l'hanno condotto a Roma (4.1.121-130); ma già nella prima parte del carme, nell'auspicare per la sua poesia il favore di Bacco, Properzio 
si era augurato di divenire il vanto dell'Umbria e, a testimonianza dell'ormai raggiunta fusione di Romani e Italici, l'aveva definita 'patria del romano Callimaco' (4.1.63-64):

ut nostris tumefacta superbiat Vmbria libris,

Vmbria Romani patria Callimachi.

Quando, intorno al 15 a.C., Properzio conclude il suo IV libro di elegie, sono trascorsi più di 25 anni dalle vicende del bellum Perusinum, che nel 41 a.C. aveva provocato il dissesto familiare di cui si parla nella $4.1 \mathrm{e}$, poi, il suo trasferimento a Roma, dove alle prospettive della carriera forense aveva preferito il richiamo della poesia (4.1.133-4):

\section{tum tibi pauca suo de carmine dictat Apollo} et vetat insano verba tonare foro.

Che Roma sia divenuta ben presto il riflesso dello stato d'animo di Properzio e delle sue mutevoli concezioni di poetica, lo si capisce dalla distanza che divide l'immagine della città del poeta d'amore da quella del cantore degli splendori della Roma augustea. La città del poeta d'amore è quella delle visite di notte o al sorgere del giorno in casa dell'amata $(1.3 ; 2.29 \mathrm{~b})$, delle suppliche e degli improperi alla porta chiusa perché si apra per accoglierlo (1.16), è la Roma della Suburra e delle audaci e acrobatiche fughe di Cinzia (4.7.15-18), degli amori 'en plein air' (4.7.19-20), delle meretrici che percorrono in lungo e in largo la via Sacra (2.23.15), delle scenate di gelosia nelle sordide taverne dell'Esquilino (4.8.19-20).

Finché Properzio si considera poeta d'amore e non pratica vie diverse, Roma è per lui lo spazio dell'amore, ${ }^{1}$ come lo era stata per Catullo e, poi, per Cornelio Gallo, il capostipite degli elegiaci latini: certo, del suo amore per Licoride conosciamo ben poco; ma che ad esso abbia fatto da sfondo l'ambiente cittadino è Virgilio ad attestarlo, quando nella $\mathrm{X}$ bucolica per lenire le sofferenze cha a Gallo provocano il tradimento e la fuga dell'amata Licoride gli suggerisce di trasferire la propria esistenza e il proprio canto d'amore in uno scenario bucolico. Che quello di Properzio sia un tipico amore cittadino lo si intuisce subito, sin da quando nella prima parte dell'elegia 1.8 egli fa di Cinzia una seconda Licoride, che vorrebbe seguire un suo occasionale ma danaroso spasimante sin nella gelida Illiria: vi rinuncerà, tuttavia, per amore del poeta e della sua poesia, e sarà quello il momento del trionfo di Properzio (1.8.31-32):

\footnotetext{
${ }^{1}$ Riprendo qui liberamente quello che sulla città quale spazio dell'amore ho scritto in Fedeli $20104-10$.
} 


\section{illi carus ego et per me carissima Roma}

dicitur, et sine me dulcia regna negat.

Per Cinzia, dunque, l'amore per Properzio s'identifica e si confonde con quello per Roma, ed è l'atteggiamento di devozione del poeta a renderle gradita la vita cittadina.

Non sappiamo dove vada ambientata la scena dell'innamoramento in seguito al fulminante sguardo di Cinzia, che Properzio descrive nel distico di apertura del I libro: forse egli allude a un incrociarsi di sguardi nella pubblica via, oppure destina a quell'occhiata ammaliatrice uno dei luoghi tipici della conquista amorosa nell'immaginario degli antichi, e dunque il teatro o il circo. Non sarà un caso, infatti, che quando Cinzia detterà a Properzio la sua formula legis di un rinnovato foedus amoris, vi inserirà un esplicito divieto di voltarsi audacemente in teatro per lanciare occhiate assassine al settore riservato alle donne (4.8.77 colla cave inflectas ad summum obliqua theatrum); ma il dubbio rimane, perché nello stesso contesto Cinzia cita, quali spazi convenzionali della conquista amorosa, anche il portico di Pompeo e i luoghi del Foro in cui si svolgevano i ludi dei gladiatori (vv. 75-76):

tu neque Pompeia spatiabere cultus in umbra, nec cum lascivum sternet harena Forum.

Il teatro, però, resta il maggiore indiziato, per testimonianza di Properzio stesso (2.22.3-10):

nulla meis frustra lustrantur compita plantis;

o nimis exitio nata theatra meo, sive aliqua in molli diducit candida gestu bracchia, seu varios incinit ore modos!

Interea nostri quaerunt sibi vulnus ocelli, candida non tecto pectore si qua sedet, sive vagi crines puris in frontibus errant,

Indica quos medio vertice gemma tenet.

I teatri, com'è noto, sono il luogo prediletto per intessere avventure galanti. È vero che l'unico teatro stabile allora esistente era quello di Pompeo: ma nel plurale del v. 4 Properzio ha in mente anche i teatri che venivano provvisoriamente allestiti per le numerose rappresentazioni drammatiche, perché per lui non si tratta di un problema di strutture, ma di presenze femminili. Però insieme ai teatri nel contesto di 2.22 compaiono anche le strade di Roma, perché - nonostante alcuni infelici tentativi di vedere nei compita del v. 3 un sinonimo di theatra - è agli angoli delle strade che Properzio 
pensa, in particolare agli incroci in cui la confluenza di più vie favorisce gli incontri occasionali: è in quello spazio che è più facile per l'aspirante seduttore attendere la preda, e incontrarla.

Lo sa bene anche Cinzia, per esperienza diretta: la sua ombra, che dopo il funerale imperfetto si presenta a Properzio, sarà pure evanescente e impalpabile, ma evidentemente non ha ancora bevuto l'acqua del Lete che dona l'oblio, perché tutto ricorda della vita in comune, specialmente di quella sessuale. Anche Cinzia, dunque, individua nei punti in cui più vie confluiscono lo spazio ideale per la conquista e svela al lettore che proprio lì all'aperto si spera al riparo da occhi indiscreti - lei e il poeta erano soliti dare sfogo a travolgenti slanci passionali, con le vesti a fare da coperte di un giaciglio improvvisato (4.7.19-20):

saepe Venus trivio commissa est, pectore mixto

fecerunt tepidas pallia nostra vias.

Sono gli amici stessi a ritenere l'amore della coppia elegiaca indissolubilmente legato alla città, al punto che Pontico nell'esordio dell'elegia $1.12^{2}$ può facilmente congetturare che Properzio non si decide a lasciare Roma perché la sua 'liaison' con la donna che ha scelto di cantare gli impedisce di allontanarsi da quel contesto cittadino che costituisce lo spazio dell'amore elegiaco (1.12.1-2):

quid mibi desidiae non cessas fingere crimen, quod faciat nobis, Pontice, Roma moram?

D'altra parte è significativo che ai periodi di dura astinenza sessuale per il tradimento faccia riscontro invariabilmente la negazione dei luoghi e dei momenti tipici della vita cittadina, tanto che, quando Properzio descrive il trionfo in amore del barbarus che gli ha sottratto la donna amata, ${ }^{3}$ la sua condizione disperata di amante abbandonato si manifesta non solo con l'inappetenza, ma anche col rifiuto di quei luoghi, come il teatro e il Campo Marzio, che dello spazio cittadino sono i simboli privilegiati (2.16.33-34):

tot iam abiere dies, cum me nec cura theatri
nec tetigit Campi, nec mea mensa iuvat.

${ }^{2}$ Naturalmente se si accetta di correggere con Kraffert nel vocativo Pontice l'improbabile conscia tràdito dai codici nel v. 2 , che andrebbe riferito a Roma. Sulla situazione testuale cfr. Fedeli 1980 288-290.

${ }^{3}$ 2.16.27-28 barbarus exutis agitat vestigia lumbis / et subito felix nunc mea regna tenet. 
Non c'è dubbio che tot iam abiere dies (v. 33) rappresenti un caso di enfatica esagerazione, perché in precedenza il poeta ha lasciato intendere che il discidium dura solo da una settimana: ${ }^{4}$ di questo potranno turbarsi quanti dagli elegiaci si attendono il preciso rispetto di una presunta realtà; è chiaro, però, che qui Properzio vuole intensificare la portata della sua condizione di exclusus, ricorrendo sia alla dilatazione del tempo della lontananza da Cinzia sia all'anafora della particella negativa, che scandisce la serie degli inutili tentativi di riprendere il ritmo normale della vita cittadina, fatta di spettacoli e di attività ginnica, oltreché di cibo.

A causa di questo suo ruolo di spazio dell'amore elegiaco, sarà la città tutta a chiacchierare sulla relazione di Properzio con Cinzia (2.20.21-22):

septima iam plenae deducitur orbita lunae, cum de me et de te compita nulla tacent.

Qui iperbolicamente Properzio immagina di trovarsi, insieme a Cinzia, al centro dell'attenzione generale e la rappresentazione dell'amore che felicemente si realizza è affidata ai rumores della gente di Roma nei tradizionali luoghi d'incontro cittadini: i crocevia, innanzi tutto, ma c'è da presumere che Properzio pensi anche ai luoghi in cui i Romani erano soliti scambiare quattro chiacchiere.

Agli stessi ambienti rinvia la situazione di 2.24a, in cui Properzio dapprima sostiene di essere ormai sulle bocche degli abituali frequentatori del Foro per i suoi carmi su Cinzia $^{5}$ e, poi, proclama che se la donna da lui cantata gli accordasse facilmente i suoi favori, egli non sarebbe vilipeso e diffamato per tutta Roma (2.24a.5-7):

quod si iam facilis spiraret Cynthia nobis,

non ego nequitiae dicerer esse caput,

nec sic per totam infamis traducerer urbem.

C’è, però, una giustizia riparatrice: sicché quando a tradire è la dispotica Cinzia, a Roma è lei a finire sulle labbra di tutti. È questa la situazione iniziale dell'elegia 2.5:

\section{Hoc verum est tota te ferri, Cynthia, Roma et non ignota vivere nequitia?}

\footnotetext{
${ }^{4}$ 2.16.23-24 numquam septenas noctes seiuncta cubares, / candida tam foedo bracchia fusa viro.

${ }^{5}$ 2.24a.1-2 tu loqueris, cum sis iam noto fabula libro / et tua sit toto Cynthia lecta foro?
} 
L'elegia si apre con una espressione di attonito stupore del poeta, poco disposto a credere alle chiacchiere su un dissoluto comportamento di Cinzia: nel verso iniziale al ritmo spondaico si uniscono - a scandire la riflessione di Properzio e a conferirle peso - l'insistente allitterazione della dentale e l'iperbato, che dilata l'ampiezza della fama in ogni angolo della città; accortamente Cinzia viene accostata a Roma, perché è Roma l'ambiente delle sue dissolutezze.

All'interno della città quale scenario dell'amore, lo spazio in cui esso si concretizza si restringe alla casa e al letto di Cinzia. Tranne che nella 4.8, Properzio non parla mai della propria casa come di un luogo d'amore, ma sempre si descrive mentre fiducioso si presenta alla porta della casa di Cinzia. Talora non sembra incontrare ostacoli sul proprio cammino, come avviene nel caso di 1.3, allorché reduce dal banchetto coglie Cinzia ancora addormentata dopo una notte di vana attesa, o di $2.29 \mathrm{~b}$, in cui la stessa situazione si ripropone di buon mattino. In entrambe le circostanze, vista la facilità dell'accesso da parte dell'amante, si potrebbe pensare alla casa di Properzio: ma non esistono accenni a una vita in comune, sia pure per brevi periodi, e questa indeterminatezza, che talora dà luogo ad apparenti contraddizioni, in realtà si iscrive nella vaghezza stessa con cui è caratterizzata la figura di Cinzia, ora meretrix ora matrona.

L'eccezione è costituita da 4.8, ma dipende dalle modalità di esecuzione del tentativo di rivalsa del poeta nei confronti del tradimento di Cinzia: se la donna amata ha deciso di scorazzare fra Roma e Lanuvio sul cocchio di un ricco ed eccentrico amante, sarà nella propria dimora a Roma, sull'Esquilino, che Properzio organizzerà un festino consolatorio con due donnine allegre. Ma il ritorno improvviso e inatteso di Cinzia è quello tipico di una domina che considera violato lo spazio dell'amore a lei sola riservato, e per questo motivo - oltre a dettare le regole di un rinnovato foedus - provvede alle purificazioni di rito, prima di sancire la pace con una battaglia erotica sul letto di Properzio.

Se, però, la norma vuole che a Roma lo spazio degli amanti sia quello della casa di Cinzia - che anche per questo motivo palesa la condizione di meretrix più spesso di quella di matrona - allora non c’è da meravigliarsi né dei frequenti accenni ai custodes che impediscono l'ingresso né della raffigurazione di una dimora in cui tutti possono entrare perché Cinzia si comporta come una grande cortigiana; ${ }^{6}$ una dimora dove i giovani si disputano animosamente la precedenza e con i loro reiterati appelli non le consentono di dormire. ${ }^{7} \grave{\mathrm{E}}$

${ }^{6}$ 2.6.1-6 Non ita complebant Ephyraeae Laidos aedis, / ad cuius iacuit Graecia tota fores; / turba Menandreae fuerat nec Thaidos olim / tanta, in qua populus lusit Ericthonius; / nec quae deletas potuit componere Thebas, / Phryne tam multis facta beata viris.

${ }^{7}$ 2.19.5-6 nulla neque ante tuos orietur rixa fenestras, / nec tibi clamatae somnus amarus erit. La rixa ante Cynthiae fenestras a cui allude Properzio nel v. 5 sarà con ogni probabilità una disputa fra spasimanti avvinazzati perché reduci dal banchetto e desiderosi di avere la precedenza nei 
sempre la casa di Cinzia, divenuta ora lo spazio del tradimento, ad accogliere per le gozzoviglie e i notturni amplessi il pretore di $2.16,{ }^{8}$ mentre il poeta si lamenta di esservi ammesso solo ogni dieci giorni ${ }^{9}$ e di non avere neppure la possibilità di far filtrare i suoi appelli accorati attraverso le fessure della porta. ${ }^{10}$ Invece, ben diversamente da quanto capita a Properzio, nel caso del pretore quella porta tota ...nocte patet (2.16.6) e per lui non esiste alcun divieto d'accesso: proprio la porta, quindi, tradizionalmente ostile al poeta e tanto spesso per lui inesorabilmente chiusa, non si limita ad aprirsi, ma addirittura si spalanca (patet) per accogliere quel bellimbusto!

Se la casa di Cinzia costituisce lo spazio dell'amore, ben si capisce perché nella fase del discidium essa possa assumere una connotazione negativa, che ben s'intona con l'atteggiamento desolato e querulo di una Cinzia che soffre per la lontananza del suo uomo e per il sospetto del tradimento. In 3.6.11-18

$\begin{array}{ll}\text { nec speculum strato vidisti, Lygdame lecto } & 11 \\ \text { scriniaque ad lecti clausa iacere pedes } & 14 \\ \text { ac maestam teneris vestem pendere lacertis? } & 13 \\ \text { Ornabat niveas nullane gemma manus? } & 12 \\ \text { Tristis erat domus, et tristes sua pensa ministrae } & 15 \\ \text { carpebant, medio nebat et ipsa loco, } & \\ \text { umidaque impressa siccabat lumina lana, } & \\ \text { rettulit et querulo iurgia nostra sono? } & \end{array}$

la condizione di abbandono e di trascuratezza in cui versa Cinzia si riflette sulla sua casa: lo specchio giace abbandonato sul letto, il cofanetto con gli ingredienti per il trucco è confinato ai piedi del letto, la veste è neghittosamente gettata sulle sue spalle e nessuna pietra preziosa adorna le sue dita.

In quale quartiere di Roma il poeta collochi lo spazio dell'amore è Cinzia stessa a dircelo, nella rievocazione dei legami di un tempo ormai passato all'interno del suo sfogo post mortem nei confronti dell'amante ingrato e immemore (4.7.15-18):

\section{iamne tibi exciderant vigilacis furta Suburae et mea nocturnis trita fenestra dolis, per quam demisso quotiens tibi fune pependi, alterna veniens in tua colla manu?}

\footnotetext{
favori sessuali, piuttosto che un alterco fra uno spasimante e il portiere o un tentativo di attirare, urlando, l'attenzione della donna.

8 2.16.5-6 nunc sine me plena funt convivia mensa, / nunc sine me tota ianua nocte patet.

9 2.17.11-12 quem modo felicem Invidia admirante ferebant, / nunc decimo admittor vix ego quoque die.

${ }^{10}$ 2.17.15-16 nec licet in triviis sicca requiescere luna, / aut per rimosas mittere verba fores.
} 
Che la scena sia ambientata nella Suburra potrà sorprendere i patetici e irriducibili sostenitori di una Cinzia matronale, mentre offre una definitiva conferma a quanti ritengono che Properzio abbia voluto conferire alla donna da lui cantata i tratti di una meretrix da commedia (quanti suoi monologhi patetici, allora, piuttosto che un tono tragico potrebbero assumere cadenze paratragiche!). Comunque sia, a una donna che viene rappresentata come una meretrix ben si addice la Suburra e alla sua condizione di vigilata da uno o più custodes che le impediscono di allontanarsi ben si adatta la descrizione di un'audace fuga dalla finestra, grazie a una corda che le consente di giungere fra le braccia di Properzio.

Insomma, nei primi tre libri di elegie sembra proprio che abbiano un ruolo solo i luoghi convenzionali del corteggiamento e dell'amore e che nulla esista al di fuori di essi. Sembra proprio che per i monumenti della Roma augustea da parte del poeta non esista alcun interesse e si direbbe che egli passi ogni giorno accanto ad essi con sguardo fugace e assente. Si capisce, però, che è il genere poetico praticato a esercitare un deciso cambiamento dei contenuti. Ciò nonostante possono presentarsi esigenze diverse, tali da preannunziare quel mutamento di rotta che nel IV libro diverrà esplicito. Se, però, si scrive poesia d'amore, è necessario ricorrere a un 'escamotage': è questo il caso dell'elegia 2.31.

Tessere l'elogio di Augusto può rivelarsi impresa non facile per un poeta d'amore: egli non può esaltarne la campagna di moralizzazione dei costumi, perché se lo facesse si porrebbe in palese contraddizione con la sua scelta della vita d'amore, che per statuto è antitetica a quella del civis Romanus politicamente impegnato; non può celebrarne, come vorrebbe, i successi militari né può cantare le glorie della gens Iulia risalendo alle sue mitiche origini, perché questo è compito del poeta epico e non di chi, come il poeta elegiaco, pratica un genere 'tenue'. Properzio, allora, escogita un modo originale di manifestare la propria adesione all'attività del principe: celebrerà lo sviluppo edilizio di Roma e lo splendore dei nuovi templi e di quelli freschi di restauro grazie all'opera di Augusto. Lo seguiremo, appunto, in due fasi diverse della sua produzione di poesia elegiaca, per vedere con quale accortezza e con quanta eleganza egli riesca a realizzare il suo compito.

All'epoca della redazione del II libro di elegie, Properzio è stato ammesso nel circolo di Mecenate, mentre Augusto, vincitore ad Azio nel 31 a.C., fra il 28 e il 27 ha avuto il riconoscimento ufficiale dei suoi poteri. Sono questi gli anni in cui Augusto dà inizio alla sua vasta e intensa opera di restauro e di costruzione dei templi e degli edifici pubblici, che è destinata a cambiare il volto di Roma. Di tali mutamenti anche il poeta d'amore è testimone attento e interessato: ben sapendo che è piuttosto singolare l'introduzione nella poesia erotica di tematiche 
connesse con l'attività edilizia, Properzio escogita un ingegnoso espediente per inserire il motivo edilizio in un contesto amoroso: egli inverte il carattere precipuo di un carme d'amore, che invece di accogliere all'interno di un tessuto erotico elementi ad esso estranei, presenterà proprio l'argomento erotico come secondario e del tutto accessorio. É quello che avviene nell'elegia 2.31:

Quaeris cur veniam tibi tardior? Aurea Phoebi porticus a magno Caesare aperta fuit.

Tanta erat in speciem Poenis digesta columnis, inter quas Danai femina turba senis.

Hic equidem Phoebo visus mibi pulchrior ipso marmoreus tacita carmen hiare lyra; atque aram circum steterant armenta Myronis, quattuor artifices, vivida signa, boves.

Tum medium claro surgebat marmore templum, et patria Phoebo carius Ortygia,

in quo Solis erat supra fastigia currus et valvae, Libyci nobile dentis opus: altera deiectos Parnasi vertice Gallos, altera maerebat funera Tantalidos.

Deinde inter matrem deus ipse interque sororem Pythius in longa carmina veste sonat.

Il tenue legame con la poesia d'amore per Cinzia è definito nel distico iniziale: a un appuntamento con la donna amata, Properzio non si è presentato in orario (v. 1) ed è proprio la causa del ritardo a fornire l'argomento del carme: colpevole del suo ritardo è stata l'inaugurazione del portico di Apollo (vv. 1-2), annesso al tempio del dio, di cui egli dà una accurata descrizione. Imponente a vedersi, il portico s'innalza su colonne perfettamente simmetriche, fra le quali sono collocate le statue delle figlie di Danao (vv. 3-4). Una statua di Apollo, più bella del dio in persona, sembra quasi intonare un carme sulla lira silenziosa (vv. 5-6). Intorno all'altare stanno quattro buoi, opera di Mirone, che sembrano vivi (vv. 7-8). Al centro s'innalza il tempio di Apollo, tutto di candido marmo, sulla cui sommità è posta la quadriga del Sole: $i$ battenti delle porte, in avorio africano, raffigurano l'uno la cacciata dei Galli dal santuario di Apollo a Delfi, l'altro lo sterminio dei figli di Niobe (vv. 9-14). All'interno, fra le statue di Latona e di Diana, è collocata quella di Apollo citaredo (vv. 15-16).

Il tempio di Apollo, che era stato votato nel 36 a.C. dopo la vittoria di Ottaviano su Sesto Pompeo a Nauloco, ${ }^{11}$ fu dedicato nel 28 a.C.: ${ }^{12}$ era situato

\footnotetext{
${ }^{11}$ Vell. 2.81.3; Cass.Dio 49.15.5.

${ }^{12}$ Cass.Dio 53.1.3; CIL I ${ }^{2}$ 214. 245. 249.
} 
in un terreno, di proprietà di Ottaviano, che era stato colpito dal fulmine. ${ }^{13} \mathrm{La}$ sistemazione definitiva appare strettamente legata alla vittoria di Ottaviano ad Azio nel 31 a.C., quando l'intero complesso architettonico assunse il valore di ex voto: è ben nota, d'altronde, la predilezione del principe per Apollo e per il suo culto. Considerata la cronologia del II libro delle elegie properziane, pubblicato non prima del 25, c'è da pensare che il portico, pur essendo incluso nel progetto originario di Ottaviano, ${ }^{14}$ sia stato aggiunto in un secondo momento, a completamento dello straordinario impegno architettonico. Ora l'opera è finalmente terminata e, una volta che anche il portico è stato inaugurato da Augusto, il poeta può descrivere l'emozione che suscita in lui la visita delle varie zone del complesso. Dalle notizie di Properzio, testimone diretto, e da quelle più tarde possiamo dedurre che il tempio, collocato al centro del complesso, era costruito in marmo di Carrara ${ }^{15}$ e s'innalzava (v. 9 surgebat) su un podio elevato. Sulla sommità del tempio era rappresentata la quadriga del Sole (v. 11). Il gruppo scultoreo della cella, che rappresentava "la prima grande manifestazione del nuovo linguaggio artistico augusteo", ${ }^{16}$ era costituito da un Apollo citaredo insieme a Diana e a Latona. Nell'area di fronte al tempio, dove sorgeva un altare circondato da quattro statue di buoi, opera di Mirone (vv. 7-8), si trovava anche una statua di Apollo citaredo (vv. 5-6). Da altre fonti veniamo a sapere che al complesso era annessa una biblioteca, ${ }^{17}$ divisa in due sezioni (greca e latina) e ornata, oltre che di imagines clipeatae di poeti e di oratori, ${ }^{18}$ di una serie di statue, fra le quali spiccava quella di Augusto con gli attributi e l'atteggiamento di Apollo. ${ }^{19}$

Gli scavi più recenti hanno messo in luce che il palazzo di Augusto aveva un passaggio diretto alla terrazza del tempio: in tal modo la dimora del principe e il luogo di culto del dio, suo protettore, costituivano un insieme unitario di grande significato ideologico. La disposizione della dimora del principe e del tempio di Apollo, infatti, era tale da dominare il Circo Massimo e da consentire ad Augusto di assistere dall'alto alle cerimonie in suo onore: lo schema era analogo a quello della reggia-santuario dei sovrani ellenistici (in particolare a quello dell'acropoli di Pergamo, in cui erano situati la reggia degli Attalidi e il tempio di Atena che sovrastavano il teatro), o ai santuari di Palestrina e di Tivoli. Il santuario che Augusto - quando ancora era Ottaviano - aveva

${ }^{13}$ Cass.Dio 49.15.5; Suet. Aug. 29.3.

${ }^{14}$ Vell. 2.81.3 templum ...Apollinis et circa porticus facturum promisit, quod ab eo singulari extructum munificentia est.

${ }^{15}$ Cfr. v. 9, Ov. Trist. 3.1.60, Serv. ad Verg. Aen. 8.720.

${ }^{16}$ Zanker 1989256.

${ }^{17}$ Suet. Aug. 29.3; Cass.Dio 53.1.3.

${ }^{18}$ Hor. Epist. 2.1.214-8, Porph. ad Hor. Epist. 2.1,214, schol. ad Hor. Sat. 1.4.21, Tac. Ann. 237.

${ }^{19}$ Schol. ad Hor. Epist. 1.3.17, Serv. ad Verg. Georg. 4.10. 
fatto erigere, a detta di Zanker "superava tutti gli altri templi per l'impianto scenografico e il suo rapporto organico con la casa del committente". ${ }^{20}$

Anche il complesso architettonico e le sue decorazioni avevano un evidente significato ideologico: altamente simbolica, dopo la vittoria su Cleopatra e sull'Egitto, era la rappresentazione delle Danaidi (v. 4), perché esse avevano ucciso i figli di Egitto; un analogo significato avevano le decorazioni, sulle porte del tempio, di Apollo quale vendicatore della bybris. Però con le immagini che simboleggiavano la vittoria e la vendetta sulla bybris dei nemici convivevano quelle che parlavano il linguaggio della pace e della devozione religiosa: per questo motivo entrambe le statue del dio Apollo (vv. 5-6. 16) lo presentavano come pacifico citaredo. La quadriga del Sole posta sulla sommità del tempio, infine, stava a simboleggiare la garanzia, offerta dal dio, dell'inizio di una nuova età dell'oro con Augusto. La costruzione del tempio di Apollo sul Palatino, dunque, rientra nel programma apollineo concepito da Ottaviano sin dall'epoca della vittoria di Nauloco nel 36 a.C. e perseguito coerentemente nei 20 anni successivi: lo attesta, parallelamente, anche la ritrattistica, in cui il volto del principe manifesta sempre una apollinea serenità; in tal senso il collegamento diretto fra la dimora del principe e il tempio segna il rapporto indissolubile fra il principe e la divinità. Per parte sua Properzio accompagna il lettore dall'esterno all'interno del tempio e si sforza di mettere in risalto tutto ciò che l'ha colpito: il lettore del tempo suo, però, capisce bene che quella di Properzio non è solo un'operazione di carattere letterario, ma è anche un modo elegante di esprimere una piena adesione al programma augusteo.

Quando dieci anni dopo, intorno al 15 a.C., Properzio pubblica il IV libro di elegie, sono trascorsi più di 15 anni dalla vittoria aziaca e la sua adesione al programma di Augusto appare sincera e convinta sin dalla prima, programmatica elegia. Per il poeta si tratta solo di saper scegliere, nella presentazione di un libro a metà strada fra poesia delle origini e poesia d'amore, quale lato esaltare dell'attività del principe: non a caso egli decide di mettere in luce l'aspetto più appariscente: quello del restauro di edifici sacri ormai fatiscenti e della costruzione di templi e di teatri. Per presentare adeguatamente il nuovo aspetto della città augustea, e per contrapporlo alla rustica semplicità della Roma delle origini, Properzio immagina di descrivere i mirabilia Romae a uno straniero, collocandosi sulla sommità del Palatino: in ordinata serie la visione degli splendidi e maestosi templi si alterna con la raffigurazione dei colli erbosi, dei simulacri di argilla, degli umili luoghi di culto dei tempi antichi (vv. 1-10); dai templi lo sguardo si sposta sui tradizionali luoghi di riunione, come la curia e i teatri, nel rispetto dell'identico schema oppositivo (vv. 11-16), mentre il

\footnotetext{
${ }^{20}$ Zanker 198973.
} 
contrasto col passato è implicito nella successiva rassegna dei culti semplici delle origini (vv. 17-26):

Hoc quodcumque vides, hospes, qua maxima Roma est, ante Phrygem Aenean collis et herba fuit;

atque ubi Navali stant sacra Palatia Phoebo, Evandri profugae procubuere boves.

Fictilibus crevere deis haec aurea templa, nec fuit opprobrio facta sine arte casa;

Tarpeiusque pater nuda de rupe tonabat et Tiberis nostris advena tbubust erat.

Qua gradibus domus ista Remi se sustulit, olim unus erat fratrum maxima regna focus.

Curia, praetexto quae nunc nitet alta senatu, pellitos habuit, rustica corda, patres.

Bucina cogebat priscos ad verba Quirites: centum illi in prati saepe senatus erat.

Nec sinuosa cavo pendebant vela theatro, pulpita sollemnes non oluere crocos.

Nulli cura fuit externos quaerere divos, cum tremeret patrio pendula turba sacro, annuaque accenso celebrata Parilia faeno, qualia nunc curto lustra novantur equo.

Vesta coronatis pauper gaudebat asellis, ducebant macrae vilia sacra boves.

Pauca saginati lustrabant compita porci, pastor et ad calamos exta litabat ovis.

Verbera pellitus saetosa movebat arator, unde licens Fabius sacra Lupercus habet.

Il movimento d'apertura è grandioso: nel verso iniziale il poeta indica all' hospes il panorama della Roma augustea e rende il suo gesto ancor più evidente grazie al deittico hoc: sui particolari si soffermerà subito dopo; per ora gli presenta la città nel suo insieme, sin dove si offre allo sguardo nella sua imponente grandezza (quodcumque vides ... qua maxima Roma est). Dopo l'enfasi celebrativa dell'esametro, è al pentametro che viene affidato il compito di presentare la realtà di un umile passato, in cui spicca la figura del 'frigio Enea', che ha il compito di simboleggiare e nobilitare le origini della città. Chiara risulta, sin dal secondo emistichio del v. 2, l'opposizione del presente al passato, che è anche una opposizione fra cultura e natura: uno scarno paesaggio fatto di collis et herba si contrappone alla maxima Roma e il perfetto fuit del pentametro al presente est dell'esametro.

Combinati col distico precedente, i vv. 3-4 ne ripropongono l'identica struttura oppositiva: l'esametro illustra il presente, il pentametro rinvia al 
passato. Nei confronti del distico precedente si avverte, però, una progressione, che consente di individuare una nuova caratteristica della Roma augustea: mentre, infatti, nel v. 1 maxima riferito a Roma aveva connotato la grandezza dell'Urbe, ora stant in rapporto col tempio di Apollo sul Palatino non si limita a mettere in risalto l'imponenza e la magnificenza di quel tempio e di altri templi fatti erigere da Augusto, ma sottolinea la sua collocazione, proprio al centro del complesso augusteo del Palatino, su un alto podio, a cui si è accennato sopra a proposito di 2.31 .

Il v. 5 muove dal passato (i fictiles dei, umili statue di terracotta) per giungere agli aurea templa del presente, che si sono ingranditi (crevere) per accogliere quegli stessi dèi allora raffigurati con materiali umili: continua, dunque, ad essere sviluppato il topos della Roma semplice dell'epoca arcaica, inserita in un paesaggio arcadico e bucolico, e il deittico ( $\mathrm{haec}$ ) ripropone il gesto iniziale del poeta che all'bospes indica gli splendori della Roma augustea, in una ideale periegesi. Nel v. 6 sembra che l'umile e disadorna capanna dei tempi antichi (facta sine arte casa) serva a fissare un generico confronto con i nuovi e lussuosi palazzi. Se, però, si considera la localizzazione della scena sul Palatino, non si può escludere che il contrasto coinvolga, da un lato le umili capanne del tempo antico (casa è un singolare collettivo), che i Romani delle origini non si vergognavano di abitare, dall'altro proprio il palazzo di Augusto sul Palatino. Se così è, nell'atteggiamento di Properzio non si deve scorgere la stessa moralistica condanna del lusso dei tempi suoi, che siamo abituati a incontrare nel coevo Orazio: al contrario, la sua è una convinta esaltazione dello sfarzo della Roma augustea.

Nei vv. 7-8 si lascia il Palatino per passare al Campidoglio, con una roboante presentazione del tempio di Giove Capitolino, in cui l'allitterazione a cornice (Tarpeius ...tonabat) e l'insistenza sulla dentale hanno il fine di riprodurre il fragore del tuono. Qualunque sia il testo molto controverso del v. 8, la contrapposizione del passato al presente è implicita sia nell'esametro sia nel pentametro, perché la nuda rupe dell'esametro sottintende un contrasto col magnifico tempio di Giove Capitolino, che ora lì si erge, mentre nel pentametro al Tevere dei tempi antichi, allora 'straniero' (advena) perché per gran parte scorreva in Etruria, si contrappone il suo percorso, ora cittadino.

Nel v. 9, dove Remi sta al posto di Romuli per motivi metrici, per decidere di quale casa Romuli si tratti, visto che la tradizione ne conosce due (una sul Campidoglio, l'altra sul Palatino), si rivela decisiva l'allusione ai gradus che, se si considera il ricorso al processo oppositivo finora seguito da Properzio, non possono indicare un elemento originario, ma un'aggiunta posteriore, come d'altronde conferma la presenza di se sustulit: di qui deriva anche che olim non può essere legato a se sustulit, ma va col periodo successivo e serve a introdurre il contrasto col passato. Prezioso si rivela un contesto della Vita Romuli (20.5), 
in cui Plutarco afferma che la casa di Romolo si trovava presso la scalinata detta scalae Caci che, situata nei pressi della discesa dal Palatino al Circo Massimo, costituiva una rampa d'accesso all'area a sud-ovest del Palatino. Se, dunque, come tutto induce a pensare, si è in presenza della casa Romuli sul Palatino, se sustulit starà ad indicare il suo nuovo aspetto dopo gli interventi di restauro, che probabilmente si resero necessari per i frequenti incendi.

Nel v. 10 l'iperbato a cornice (unus ...focus) caratterizza la capanna di Faustolo (non lontana dal fiume da cui i gemelli erano stati da lui prodigiosamente salvati) non solo come tutto il loro regno, ma come il simbolo di una concordia ancora integra e non insidiata dalla lotta fratricida per il potere. $\mathrm{E}$ probabile che, con un parallelismo verticale, maxima regna debba riallacciarsi a maxima Roma del v. 1 e serva a contrapporre due diversi ideali di grandezza: quello della Roma primitiva, che si fondava sulla semplicità e sulla povertà, e quello della Roma augustea, che invece s'identificava con la grandezza e la magnificenza.

Nei vv. 11-12 è il 'sistema della moda' dei rustici senatori vestiti di pelle del tempo antico ad essere contrapposto alle sontuose toghe preteste e allo splendore della Curia in epoca augustea; in questo caso l'opposizione è con la vetusta curia Hostilia. Sarebbe sbagliato, però, credere che nella contrapposizione relativa al 'sistema della moda' dei senatori antichi e moderni sia presente il motivo topico della decadenza continua dei costumi romani a confronto con la virtù antica dei maiores e, dunque, che vi si debba ravvisare il motivo della superiorità della Roma del passato su quella augustea. Subito dopo, nei vv. 13-14, la semplicità della convocazione dei comizi per mezzo della bucina dei pastori, e non col suono del corno, e gli spazi all'aperto in cui si svolgevano le riunioni dei senatori sono implicitamente opposti alla situazione dei tempi presenti. Il luogo di riunione del senato delle origini, quando ancora non esisteva la curia Hostilia, era uno spazio all'aperto ben delimitato (templum, appunto) e consacrato dagli auguri: a tali riunioni si allude nel v. 14 con in prati saepe, che indica un prato recintato da uno steccato e sicuramente consacrato, in cui si radunava il senato primitivo. Implicita, nella specificazione del numero dei senatori al tempo di Romolo, è la contrapposizione col senato augusteo, che non solo si radunava nella curia Iulia, ma ormai era costituito da 600 senatori. ${ }^{21}$

Ancor più netto, nei vv. 15-16, è il contrasto dei teatri, che fino all'inaugurazione di quello di Pompeo nel 55 a.C. non prevedevano strutture stabili: a sollecitare il confronto saranno state sia la ricostruzione del teatro di Pompeo, voluta da Ottaviano nel 32 a.C., sia l'edificazione del theatrum Marcelli, che era certamente attivo nel 17 a.C. Dei teatri contemporanei si

\footnotetext{
${ }^{21}$ Cfr. Cass.Dio 54.13-14.
} 
mette in risalto la raffinatezza nell'uso dei vela (i teli di lino che dovevano riparare dal sole gli spettatori) e l'esotica consuetudine di profumare la scena. Tutto ciò non avveniva quando la scena era costituita dai pulpita, piattaforme in legno su cui gli attori recitavano, e l'assenza di particolari profumi costringeva gli spettatori ad annusare odori molto meno gradevoli.

Esaurita col v. 16 la sezione dedicata agli edifici, l'attenzione di Properzio si sposta sui sacra: ma se nei vv. 19-20 è esplicita la menzione dei Parilia, che si celebravano in aprile, e nei vv. 21-26 si può individuare la successione Vestalia (vv. 21-22: celebrati in giugno), Compitalia (vv. 23-24: celebrati fra dicembre e gennaio), Lupercalia (vv. 25-26: celebrati in febbraio), rimane dubbia la festa a cui si allude nei vv. 17-18: è possibile che Properzio pensi alle feriae Latinae, celebrate nel mese di aprile. In ogni caso è certo che la collocazione di nulli all'inizio del v. 17 è destinata a creare un forte contrasto fra il passato e il presente implicitamente evocato: nei tempi antichi nessuno si preoccupava di ricercare divinità straniere, diversamente da quanto accade al tempo di Properzio. Non credo affatto, però, che in nunc ...novantur del v. 20 si debba vedere una polemica nei confronti del principe, perché essa sarebbe in contraddizione con la piena adesione di Properzio alla sua politica in materia di culti: gli externi divi del v. 17, dunque, non saranno né tutte le divinità diverse da quelle indigene delle origini né gli dèi della Grecia, ma piuttosto le divinità celebrate nei culti orientali, che tanto successo stavano riscuotendo allora a Roma. Properzio, quindi, si pone in linea anche con la politica augustea di restaurazione degli antichi culti e delle antiche feste, a cominciare dai Compitalia e dai Lupercalia, in contrapposizione alla moda di praticare i culti orientali: il suo, di conseguenza, vuole essere un invito a condividere la politica religiosa del principe, che all'immissione dei culti orientali intendeva mettere un freno; non a caso fra i consigli ad Augusto attribuiti a Mecenate da Cassio Dione, quelli in materia di limitazione dei culti orientali, considerati come possibile fonte di disordini, hanno un ruolo importante. ${ }^{22}$

Si può dire, dunque, che nella parte iniziale della prima elegia del IV libro domina il motivo del contrasto, che si manifesta in più d'un modo: il più evidente è quello fra la città augustea e la città delle origini, che è sviluppato sin dall'esordio, in cui l'hospes viene sollecitato a immaginarsi, là dove ora si erge imponente la Roma augustea, un solitario paesaggio di colli e di campi erbosi (vv. 1-2), e dove splendido s'innalza il tempio di Apollo sul Palatino, un luogo di pascolo e di ristoro per le sfinite giovenche di Evandro (vv. 3-4). In seguito il contrasto fra presente e passato coinvolge i fictiles dei delle origini e gli aurea templa augustei, le umili case del tempo antico e la dimora di Augusto sul Palatino (vv. 5-6), il tempio di Giove Capitolino e la rupe

\footnotetext{
${ }^{22}$ Cass.Dio 52.36.
} 
Tarpea ancora priva di edifici (v. 7), la funzione stessa del Tevere, un tempo fiume straniero perché scorreva in terra etrusca e ora inserito nel territorio urbano della Roma augustea (v. 8), la restaurata casa Romuli sul Palatino e la capanna di Faustolo (vv. 9-10). Subito dopo il contrasto si amplia al 'sistema della moda', con la contrapposizione delle pelli indossate dai rustici senatori alle sontuose toghe preteste (vv. 11-12), per fare poi ritorno ai luoghi di governo e di aggregazione: il prato recintato da uno steccato in cui si radunava il senato delle origini e, di contro, la solenne Curia Iulia (v. 14), i teatri provvisori di una volta e quelli stabili di ora (vv. 15-16). Esaurita la sezione dedicata ai luoghi e agli edifici della città, il contrasto col presente si sposta sulle feste sacre (vv. 17-26), che un tempo si caratterizzavano per la loro agricola semplicità.

Come ha scritto Paul Zanker, Augusto capì che "l'immagine complessiva di una città in una certa situazione storica rappresenta un coerente sistema di comunicazione visiva, in grado di influenzare gli abitanti anche a livello inconscio per il fatto stesso della sua continua presenza". ${ }^{23}$ Augusto aveva ereditato una città, la Roma repubblicana, tutt'altro che simile alle capitali del mondo ellenistico e dal punto di vista edilizio del tutto inadeguata al suo ruolo di capitale di un imperium mondiale. C'è da tener presente che a Roma il massimo sforzo edilizio era stato compiuto nei primi decenni del II sec. a.C.: ma ora, a due secoli di distanza, templi ed edifici pubblici apparivano in massima parte cadenti e fatiscenti, non solo perché gli interventi di restauro si erano praticamente arrestati al tempo dei Gracchi, ma anche perché nessuno aveva concepito un progetto organico di sviluppo urbanistico. Se ne può capire il motivo: favorire opere di restauro serviva ben poco a fini politici di consenso e il senato, per parte sua, si opponeva alla costruzione di quanto, come i teatri e le terme, prevedeva una presenza collettiva e, dunque, poteva favorire l'organizzazione di sommosse. Augusto ebbe l'intelligenza di legare il suo programma di rinnovamento edilizio a quello di esaltazione dei valori religiosi, ed è proprio questa stretta associazione che Properzio intende mettere in luce: sin dal periodo immediatamente successivo ad Azio, Augusto non solo favorì la costruzione dell'imponente tempio dedicato ad Apollo, eletto a suo protettore nella vittoria aziaca, ma contemporaneamente fece erigere il Mausoleo e trasformò profondamente il Foro. A partire da quell'epoca egli non si limitò a realizzare un programma di edificazione di imponenti palazzi pubblici, a testimonianza della maestà dell'impero, ma volle costantemente associare l'attualità al rispetto della tradizione: ciò, d'altronde, era perfettamente in linea col suo programma ideologico, secondo cui l'impero costituiva una logica

\footnotetext{
${ }^{23}$ Zanker 200823.
} 
prosecuzione della repubblica, di cui recuperava e manteneva tutti i valori essenziali.

Alla luce di tutto ciò, qual è il senso dell'operazione compiuta da Properzio all'inizio del suo IV libro di elegie? Mi sembra chiaro che egli cerchi di mantenere un giusto mezzo fra culto delle origini e ammirazione per la politica edilizia e religiosa di Augusto: se da un lato, infatti, non c'è alcuna condanna del lusso e degli splendori della Roma augustea, dall'altro non c'è neppure un rifiuto del passato, non solo perché esso s’identifica con le origini di Roma, ma anche perché esso è considerato alla luce di una ininterrotta continuità fra la Roma delle origini e quella di Augusto. Si dirà che questa è una tendenza comune a tutti i letterati augustei: è vero, però in Properzio c'è qualcosa di più, perché la sua non è una semplice rievocazione dai toni nostalgici della Roma dei tempi antichi, ma una sua "evocazione in chiave positiva di crescita, che valorizza il presente sorto su quel passato" 24 e corrisponde al volere degli dèi.

Dovremmo vedere nel poeta, dunque, un puro e semplice propagandista della politica augustea di restauro e di nuova edificazione? A me sembra che per lui valga la stessa constatazione fatta da Paul Zanker per quanti si sforzarono di celebrare il principe con monumenti e immagini di carattere politico-religioso: "chiunque nell'impero avesse voluto mostrarsi grato all'imperatore avrebbe potuto adottare le formule figurative diffuse inizialmente a Roma o da Roma, o anche impiegare nuove immagini che si adattassero al programma precostituito. Non esisteva nessun ufficio addetto alla propaganda e nessun'autorità di controllo che diffondesse formule figurative o impartisse prescrizioni di qualsiasi tipo. Dato che tutti guardavano a Roma, all'imperatore e al Senato, si formava piuttosto un orientamento generale e una forma di autocontrollo. Non abbiamo quindi a che fare con una propaganda mirata nel senso moderno, dove un'autorità centrale dirama precise parole d'ordine e immagini finalizzate a indottrinare la popolazione". ${ }^{25}$

Liberato, dunque, dalla facile ma in realtà futile accusa di servilismo, in definitiva quello di Properzio, che mette in risalto come Roma abbia raggiunto il massimo splendore muovendo da umili origini, si rivela un tentativo di mediazione fra i valori perduti del tempo antico e il trionfalismo augusteo. Ma nello spirito dei tempi nuovi inaugurato dai ludi saeculares del 17 a.C., il progetto stesso di cantare sacra diesque, espresso nel v. 69 dell'elegia iniziale e programmatica del IV libro, s'inserisce efficacemente nell'interesse del principe nei confronti della religione romana arcaica, dei culti e delle abitudini dei tempi antichi, nella sua viva inclinazione a far rivivere il passato nel tempo suo. Di conseguenza la scelta della poesia eziologica si carica anch'essa di un

\footnotetext{
${ }^{24}$ Gazich 1997308.

${ }^{25}$ Zanker 2008111.
} 
forte significato ideologico, perché allo stesso modo dell'epos di Virgilio, della lirica civile di Orazio, dell'opera antiquaria di Varrone e della storiografia di Livio, anche l'umile poesia delle origini in distici elegiaci può contribuire a mettere in risalto alcuni aspetti che stanno molto a cuore al principe. Una simile operazione viene condotta a termine in modo tutt'altro che grossolano, ma anzi con raffinata eleganza, senza ricorrere mai alla smaccata adulazione nei confronti del principe. Però il lettore, allora come oggi, di fronte a un testo deve fare la sua parte: sarà compito suo, allora, trarre le conclusioni, che lo porteranno a celebrare insieme al poeta l'elogio di Augusto. In quanto a Properzio, è significativo che egli, per tessere l'elogio dell'attività del principe, non abbia sentito alcun bisogno di fare il suo nome o quello dei suoi collaboratori illustri: a parlare sono gli edifici stessi della Roma augustea e la loro maestosa grandiosità costituisce di per sé il massimo elogio dell'attività di Augusto. 


\section{LUOGHI DELLA CATTURA D'AMORE: A SPASSO CON OVIDIO TRA PORTICI, TEATRI E FORI ROMANI}

Rosalba Dimundo

Universidade de Bari

Rispetto alla precedente produzione elegiaca, gli scenari della poesia erotica ovidiana esprimono una più esplicita vocazione urbana e hanno la concretezza e i contorni ben noti di Roma. Come già altri poeti augustei, che alla grandezza monumentale di Roma avevano dedicato encomi celebri e suggestivi ${ }^{1}$, anche Ovidio è affascinato dall'Urbs, ma il suo elogio della città eterna muove da presupposti del tutto nuovi: Roma, luogo ideale per l'amore, infatti, rappresenta per Ovidio soprattutto lo scenario perfetto in cui ambientare le raffinate strategie della "conquista'. Allo spazio chiuso dell'elegia erotica, che si identificava preferibilmente con quello intimo e angusto del lectus, con ironica disinvoltura Ovidio sostituisce lo spazio aperto e affollato (il circo, il teatro, il banchetto). Se Properzio assisteva al trionfo di Augusto da lontano, stretto tra le braccia della sua amata Cinzia, sottolineando in tal modo la distanza anche ideologica da un mondo e da un sistema di relazioni del tutto estraneo al proprio microcosmo, Ovidio, nell'esortare il suo discepolo a partecipare a queste manifestazioni civili, da una parte evidenzia la totale adesione alla politica di Augusto, dall'altra mette in luce il risvolto pratico di tale partecipazione: anche il trionfo, infatti, può trasformarsi in una splendida possibilità di cattura della donna prescelta. Non di rado, dunque, i celebri monumenti o i luoghi più 'à la page' di Roma fanno da sfondo all'elegante messinscena d'amore progettata con minuziosa cura da Ovidio. In tale prospettiva, è soprattutto la didascalica d'amore che meglio si presta a esemplificare l'esaltazione che Ovidio propone "del mondo urbano degli amori" e la sua "adesione entusiasta alla civiltà in cui era radicata la sua pratica di poesia e all'ordine sociale e politico che la garantiva" 3 .

Conformemente alla tradizione didascalica, anche l'Ars è caratterizzata da una strutturazione articolata e precisa. Nella partitio ${ }^{4}$, in cui viene

${ }^{1}$ Basti citare Verg. Aen. 8,337-61; Prop. 2,31; 4,6 (tempio di Apollo sul Palatino) e 4,10 (tempio di Giove Feretrio).

${ }^{2}$ Al motivo di Roma come spazio scenografico dell'erotica ovidiana ha dedicato pagine interessanti Armstrong 2005, 115-139.

${ }^{3}$ Le osservazioni virgolettate sono tratte da Labate 1984,48; la lucida analisi dello studioso ha segnato un notevole progresso negli studi, perché ha sottolineato non già l'estraneità ovidiana dalla restaurazione augustea, ma addirittura lo sforzo di integrazione e di accostamento tra i due mondi, quello politico e quello erotico, tradizionalmente contrapposti.

${ }^{4}$ Com'è noto, la partitio rappresenta "l'enumerazione introduttiva sui punti da trattare, prima di una narratio o di una argumentatio": cfr. Lausberg 1969,159 (§ 296, 2). 
delineato il piano dell'opera, il poeta somministra al suo lettore indicazioni dettagliate per il reperimento dell'oggetto da amare (vv. 41-262). L'inventio deve attuarsi preferibilmente a Roma (vv.41-66), che più di ogni altro luogo offre sorprendenti possibilità di 'caccia', e nell'ambito della grande Urbs il discorso precettistico restringe i confini di pertinenza spaziale e individua con precisione i luoghi e le occasioni d'incontro: i portici (vv.67-74), gli spazi preposti al culto (vv.75-78), i fori e i tribunali (vv.79-88), il teatro (vv.89-134), il circo (vv. 135-170) e la naumachia (vv. 171-176).

Da buon precettore, il poeta sa bene che bisogna invogliare il proprio allievo attraverso una 'semplificazione' del processo di apprendimento e in tale prospettiva si inserisce la puntualizzazione sulla facilità della localizzazione della 'cattura d'amore': a differenza di Perseo che condusse con sé nigris...ab Indis l'amata Andromeda (vv.53-54), infatti, l'aspirante amator non ha affatto bisogno di spostarsi dai luoghi frequentati abitualmente, ma potrà effettuare comodamente la sua scelta a Roma, luogo che, più di ogni altro, garantisce il successo della ricerca dell'oggetto da amare:

Tot tibi tamque dabit formosas Roma puellas,

'baec habet' ut dicas 'quicquid in orbe fuit.'

Gargara quot segetes, quot habet Methymna racemos,

aequore quot pisces, fronde teguntur aves,

quot caelum stellas, tot habet tua Roma puellas:

mater in Aeneae constitit urbe sui.

Seu caperis primis et adhuc crescentibus annis,

ante oculos veniet vera puella tuos;

sive cupis iuvenem, iuvenes tibi mille placebunt:

cogeris voti nescius esse tui:

seu te forte iuvat sera et sapientior aetas,

hoc quoque, crede mibi, plenius agmen erit (vv. 55-66).

Il distico 55-56 rinvia chiaramente a Properzio 3,22,17-18 omnia Romanae cedent miracula terrae: / natura bic posuit quidquid ubique fuit, a sua volta di chiara ispirazione virgiliana: quello properziano, infatti, è il celebre contesto delle laudes Italiae, che dipende da Georg. 1,135-136. Sebbene sia profondamente mutato il contesto in cui l'elogio di Roma è inserito, da parte di Ovidio esiste un'autentica condivisione del sistema che regola la realtà contemporanea; come sottolinea Labate, "l'elogio di un poeta galante non potrà che essere frivolo e spiritoso, potrà anche parodiare, canzonare: ma senza trarsi fuori, negare"; quelli di Properzio e di Ovidio, infatti, "sono due modi, letterariamente e culturalmente diversi, di tradurre lo stesso consenso, la stessa adesione al presente"

\footnotetext{
${ }^{5}$ Non pensa ad una posizione antiaugustea nemmeno Hollis 1977,87.
} 
Roma, dunque, detiene il primato tra i luoghi dell'inventio, perché contiene tutte le ragazze che virtualmente possono costituire oggetto di scelta da parte dell'aspirante amante $(\mathrm{vv} .57-60)^{6}$, come illustrano i termini del paragone iperbolico, che afferiscono a ogni aspetto del reale (terra, acqua e aria). Nei vv.59-60 non è difficile scorgere un messaggio contraddittorio rispetto a quello fornito più volte da Properzio ai suoi interlocutori: in Ovidio, infatti, la puella destinataria degli elogi non è più una donna inimitabile, come la Cynthia rara, che con la sua forma e le sue straordinarie doti rappresentava l'unico bene del poeta, per cui valeva la pena di vivere e di soffrire; pur non essendo incolta o priva di affascinanti virtù, la fanciulla dell'Ars non ha né un nome né un fascino irresistibile, perché rientra nel numero delle tante belle e desiderabili che affollano le strade di Roma ${ }^{7}$. Constitit suggerisce l'immagine del definitivo insediamento - con la gloria che deriva alla meta prescelta - da parte di una divinità alata che proviene dalle sfere celesti ${ }^{8}$. Le parole di Ovidio, dunque, esprimono un omaggio a Roma, perché dal suo punto di vista - che è quello del precettore d'amore - l'importanza di Roma, fondata dal figlio di Venere, non risiede solo nella sua gloria politico-militare, da altri celebrata con accenti di ampio consenso, ma anche nelle illimitate occasioni di incontro che essa offre ai giovani amanti.

Una volta indicato il luogo migliore per trovare innumerevoli puellae, il motivo della 'cattura' della preda è reso esplicito nel v.61 da capio, verbo tecnico della conquista d'amore. Nel suo impiego, tuttavia, Ovidio sembra prendere le distanze dai praecepta precedentemente espressi e dal modo di intendere il processo di innamoramento: la forma passiva di capio, infatti, impone una immediata metamorfosi del cacciatore in preda; nel pentametro successivo, per di più, il riferimento agli occhi potrebbe essere una sottile allusione al verso iniziale di Prop. 1,1,1 (Cynthia prima suis miserum me cepit ocellis), in cui il verbo esplicita il topos elegiaco della cattura d'amore. A ben guardare, tuttavia, nel contesto ovidiano sia capio sia oculus sono inseriti in tutt'altro tipo di argomentazioni e la terminologia elegiaca cambia radicalmente di segno; gli oculi, infatti, non sono strumento di cattura, ma divengono oggetto passivo di una scelta casuale (ante oculos). Nell'uso di primis annis (=iuventus ${ }^{9}$ ), l'astratto per il concreto rende impersonale il discorso, in linea con la sua finalità didascalica. A sottolineare la veridicità dell'affermazione concorrono, poi, l'allitterazione (veniet vera) e l'iperbato a cornice (oculos...tuos). Crede mibi

\footnotetext{
${ }^{6}$ Sul singolare parallelo tra Roma e ambiente naturale cfr. Néraudau 1985,36-37.

${ }^{7}$ Diverso sarà il fine dell'esaltazione di Roma in Rem. 291-292.

${ }^{8}$ Possono citarsi come paralleli Verg. Aen. 4,252-253 bic primum paribus nitens Cyllenius alis /constitit e Prop. 3,18,8 quis deus in vestra constitit hostis aqua?: cfr. Hollis 1977,43.

${ }^{9}$ L' espressione ricorre anche nel v.181, in Met. 7,216 e in Trist. 4,4,27.
} 
(v.66) - frequente nelle opere erotiche di Ovidio ${ }^{10}$ - introduce un intervento personale dell'autore, il quale fa appello all'esperienza privata per rendere più persuasivo il messaggio, e segna decisamente la conclusione della sezione introduttiva.

A partire dal v.67 il discorso precettistico procede in modo più sistematico e il poeta indica con esattezza i luoghi che offrono ampia possibilità di trovare le donne:

Tu modo Pompeia lentus spatiare sub umbra, cum Sol Herculei terga Leonis adit, aut ubi muneribus nati sua munera mater addidit, externo marmore dives opus; nec tibi vitetur quae, priscis sparsa tabellis porticus auctoris Livia nomen habet, quaque parare necem miseris patruelibus ausae

Belides et stricto stat ferus ense pater (vv. 67-74).

In Pompeia... sub umbra (v.67) va colto il riferimento al portico di Pompeo, la passeggiata coperta che, insieme con il teatro di Pompeo, costituiva un unico complesso monumentale fra il Campo Marzio e il Campidoglio; realizzato da Pompeo nell'anno del suo secondo consolato (55 a.C.), il complesso costituiva il tradizionale luogo d'incontro dei giovani romani, che cercavano di abbordare fanciulle non troppo ritrose ${ }^{11}$. La medesima ambulatio costituisce lo scenario della ricerca dell'amico Comerio da parte di Catullo (55,6-7 in Magni simul ambulatione / femellas omnes, amice, prendi).

In lentus spatiare sub umbra non sembra improbabile una velata allusione a Buc.1,4 nos patriam fugimus: tu Tityre lentus in umbra; tuttavia il tessuto allusivo che caratterizza il v. 67 - il cui praeceptum sarà riproposto in 3,387 at licet et prodest Pompeias ire per umbras - è squisitamente elegiaco, perché risulta chiaramente ricalcato su Prop. 4,8,75 tu neque Pompeia spatiabere cultus in umbra, in cui non a caso il divieto di Cinzia, che s'inserisce nella nuova formulazione del foedus amoris, sta ad attestare il ruolo rilevante della porticus Pompeia (Ovidio a sua volta è imitato da Marziale 11,47,3 cur nec Pompeia

${ }^{10}$ Cfr. 2,464.717; 3,653.664; Am. 1,9,2; 2,2,51;3,4,11 ed Her. 11,65; cfr., poi, l'unica attestazione nelle Metamorfosi in 1,361 e la leggera variazione in 14,244 del più raro mibi crede, su cui cfr. 2,259; Am. 2,2,9; 3,6,21 e Bömer 1969,122.

${ }^{11}$ Una dettagliata descrizione del complesso monumentale è in P. Gros, Porticus Pompei, LTVR IV [1999] 148. Anche il v.67 è citato da Giangrande 1991,61-98 come esempio di amplificazione ('Erweiterung'); gli elegiaci, infatti, amplificavano topoi ellenistici introducendovi schemi squisitamente romani. Del resto il motivo del 'luogo della caccia d'amore', in particolare del luogo sacro preposto alle funzioni religiose, dove è possibile incontrare le fanciulle, è già nel romanzo greco: un ricchissimo repertorio di passi relativi a questo tema è in Dilthey 1863,49-50; cfr., inoltre, le ottime considerazioni di Buchholz 1954,19-20. 
lentus spatiatur in umbra); lentus e spatiari, inoltre, suggeriscono l'idea di una lenta e attenta passeggiata, per poter individuare accuratamente la preda ${ }^{12}$.

I riecheggiamenti virgiliani non si esauriscono con l'esametro, ma si estendono nel pentametro: anche l'aspirante amante, come il fattore contadino, cui sono dispensati i precetti delle Georgiche, deve conoscere la propria scienza ed esser pronto all'azione sulla base di segni e di pronostici naturali ${ }^{13}$. Lespressione Herculei...Leonis, che indica il leone di Nemea (Argolide) ucciso da Ercole e identificato con la costellazione del Leone (il sole entra nella costellazione del Leone intorno al 23 luglio), esprime la possibilità di cacciare nel periodo più caldo dell'anno, quando, cioè, anche le puellae cercano sollievo alla calura estiva proprio nel fresco dei portici, che per di più offrono la complicità dell'ombra.

Nei vv.69-70, caratterizzati da giuochi fonico-stilistici (suono $u$; allitterazione polisillabica muneribus... munera mater e poliptoto), il portico di Ottavia - che non va confuso con la Porticus Octavia del 168 a.C., restaurata da Ottaviano nel 33 a.C. e dedicata al nome della sorella dell'imperatore qualche tempo dopo il 27 a.C. - è designato da un'espressione ampollosa, che sottolinea l'importanza della famiglia citata e la ricchezza di marmi stranieri che l'adornavano ${ }^{14}$. Addidit (v.70) è di dubbia interpretazione, perché oltre ad indicare contiguità spaziale, può riferirsi alla biblioteca inserita nel portico (munera) e dedicata secondo Plutarco (Marc. 30,11) alla memoria di Marcello. La litote nec tibi vitetur inaugura la porzione di testo relativa ai portici e ai luoghi di rito (71-74); il riferimento è qui al portico di Livia, tra l'Esquilino e l'Oppio ${ }^{15}$. Sebbene non ci siano ulteriori testimonianze, le priscae tabellae - con ogni probabilità pitture di soggetto antico - dovevano costituire, come era consueto in quei tempi, l'abbellimento del portico, che solitamente comprendeva anche statue.

Nell'ultimo portico o complesso di portici menzionato, annesso da Augusto al tempio di Apollo Palatino e corredato da una biblioteca greca e latina ${ }^{16}$, oltre a quelle delle 50 figlie di Danao era collocata presumibilmente anche la statua dello stesso Danao. Non è senza significato che qui le Danaidi

${ }^{12}$ Spatiari è verbo frequente per indicare soprattutto la passeggiata nei portici: $\mathrm{cfr}$. $\mathrm{Am}$. 2,2,3-4; 3,1,5; Her. 21,99; Rem. 85.627; Trist. 2,285; Petron. 90,1; 126,3; Plin. Epist. 7,272 e McKeown 1998,30.

${ }^{13}$ Cfr. Leach 1964,150 n.9.

${ }^{14}$ Dives detto "de rebus corporeis" e attestato qui per la prima volta, ricompare in Met. 10,307 (tellus) dives amomo.

${ }^{15}$ Il portico, dedicato a Livia Drusilla, moglie di Augusto dal 38, venne edificato sul sito dell'immensa villa di Vedio Pollione, abbattuta da Augusto perché esempio di sfarzo edilizio (lo ricorderà Ovidio stesso in Fast. 6,639-40 ubi Livia nunc est/ porticus, immensae tecta fuere domus).

${ }^{16} \mathrm{La}$ storica inaugurazione del portico annesso da Augusto al tempio di Apollo sul Palatino viene presentata da Properzio in 2,31; cfr., inoltre, Suet. Aug. 29,4 templum Apollinis... excitavit....addidit porticus cum bibliotheca Latina Graecaque e Hor. Carm. 1,31,1-2 quid dedicatum poscit Apollinem / vates? 
vengano definite Belides (v.74) - come anche in Trist. 3,1,61- 62 - dal nome del nonno Belo, padre di Danao e di Egitto: comè noto, su istigazione del padre esse uccisero nella prima notte di nozze, ad eccezione di Ipermestra, i loro mariti, figli dello zio paterno Egitto e perciò loro cugini (patrueles). Il riferimento al nonno attraverso il termine Belides è un modo di sottolineare la stretta parentela e il legame di sangue doppiamente oltraggiato. La collocazione di tali statue in un luogo di grande prestigio si caricava di un forte significato, perché indicava sia la condanna delle guerre fratricide, sia quella del delitto contro il sacro vincolo matrimoniale ${ }^{17}$.

Sulle fortunate occasioni di incontro che le eleganti porticus romane offrono al suo allievo, il maestro d'amore ritorna anche in un contesto successivo del libro, non senza aver prima sottolineato, però, che anche a piedi la fanciulla potrà essere opportunamente accostata; il corteggiatore, infatti, avrà la possibilità di seguirla, ma dovrà fare in modo di non essere frettoloso e tradire, così, un temperamento irruento e disastrosamente 'intempestivo' nell'ampio portico:

Seu pedibus vacuis illi spatiosa teretur porticus, hic socias tu quoque iunge moras, et modo praecedas facito, modo terga sequaris et modo festines, et modo lentus eas.

Nec tibi de mediis aliquot transire columnas sit pudor aut lateri continuasse latus (vv.491-496).

Il forte iperbato (spatiosa.../ porticus) sottolinea significativamente il termine 'architettonico' ${ }^{18}$ : legato da 'enjambement' all'esametro precedente, esso rimarca il concetto di ampiezza già insito nell'epiteto spatiosus; al corteggiatore, inoltre, spetterà il compito di creare una sorta di tacita societas (v.492 socias... moras). Nel distico successivo il praeceptor segnala con scrupolosa cura la tipologia del 'passo' da adottare; si capisce, inoltre, che la scelta dell'opportunitas è fondamentale e determina un adeguato incessus. Se nell'esametro viene dato rilievo alla coordinata spaziale del 'pedinamento' - a volte, infatti, l'amante deve fare in modo di trovarsi 'davanti', altre volte di spalle (v.493 et modo praecedas

${ }^{17}$ Riferimenti alla storia di Ipermestra rappresentata nel portico del tempio di Apollo sul Palatino, oltre che nei passi citati in precedenza e in Ov. Her. 14, si trovano in Hor. Carm. 2,14,18; 3,11,23-24; Tib. 1,3,79-80 e Prop. 4,7,67-68.

${ }_{18}$ Analogamente al v.67, anche in questo caso la porticus è il grande portico di Pompeo. Come sottolinea Labate 1984,210 "l'adsectatio galante comincia dalle intraprendenti manovre del seduttore: egli esibisce la sua capacità di servizio con un accompagnamento non richiesto, che prima simula la casualità, per assumere poi gradualmente i connotati di una passeggiata comune". 
facito, modo terga sequaris) - nel pentametro si sottolinea quella temporale (et modo festines et modo lentus eas). In entrambi i versi l'anaforico modo scandisce, con l'esattezza di un'elencazione casistica, i tempi e gli spazi.

Alla parte propositiva fa seguito una 'prescrittiva', con la segnalazione degli atteggiamenti da evitare: in questo caso, nello spazio invariato (si parla ancora dell'ampio portico di Pompeo) il corteggiatore deve dar prova di audacia (cfr. vv.495-496 nec tibi...transire... / sit pudor ${ }^{19}$ ). Il pudor da mettere da parte, naturalmente, non è tanto l'esitazione nel superare gli ostacoli, qui rappresentati dalle colonne, quanto il fastidioso ritegno di procedere affiancato alla donna (lateri continuasse latus $^{20}$ ).

Un altro spazio ideale per 'cacciare' la preda d'amore è costituito paradossalmente dai luoghi di culto e da quelli dove si esercita l'attività legale:

Nec te praetereat Veneri ploratus Adonis, cultaque Iudaeo septima sacra Syro, nec fuge linigerae Memphitica templa iuvencae: multas illa facit quod fuit ipsa Iovi.

Et fora conveniunt (quis credere possit?) amori flammaque in arguto saepe reperta foro.

Subdita qua Veneris facto de marmore templo Appias expressis aëra pulsat aquis, illo saepe loco capitur consultus Amori, quique aliis cavit, non cavet ipse sibi; illo saepe loco desunt sua verba diserto, resque novae veniunt causaque agenda sua est.

Hunc Venus e templis, quae sunt confinia, ridet: qui modo patronus, nunc cupit esse cliens (vv.75-88).

Il motivo letterario, ricorrente soprattutto nella $\mathrm{Nea}$, rifletteva una consuetudine reale, perché le feste sacre in Grecia erano le poche occasioni in cui una donna giovane e rispettabile poteva mostrarsi in pubblico ${ }^{21}$. Ovidio non trascura di far riferimento ai riti sacri di comunità ebree a Roma (v.76) - il cui peso economico e politico e la stretta osservanza del cerimoniale religioso

${ }^{19}$ Nec sit pudor e simili sono espressioni tipiche dello stile didascalico: cfr. 2,252 nec tibi sit... pudor, 720 non obstet... pudor e Rem. 352 nec pudor obstet; cfr. anche Verg. Georg. 1,79-80 tantum /ne...pudeat.

${ }^{20}$ Non a caso Murgatroyd 1982,113 sottolinea l'ironia ovidiana nell'impartire tale praeceptum dalla valenza anfibologica: "brushing against the woman (apart from being pleasurable in itself) would be an unobtrusive sign of the reader's interest (it would seem accidental to anyone who actually noticed it)".

${ }^{21}$ Alcuni versi di Difilo (Fr. 43,39-40 Edmonds; ap. Athen. 7,292d) rendono plausibile l'ipotesi che le feste in onore di Adone, il giovane amante di Venere ucciso da un cinghiale, siano state frequentate soprattutto da meretrici. 
sono ampiamente testimoniati - e al culto isiaco (vv.77-78), che si diffuse a Roma all'inizio del I secolo a.C.; le misure restrittive prese sotto Augusto e Tiberio non limitarono la frequenza soprattutto femminile di tali riti: se ne ha testimonianza letteraria, del resto, nella stessa poesia elegiaca, le cui eroine sono regolarmente descritte come devote di Iside. Le perifrasi linigerae... iuvencae e Memphitica templa da un lato impreziosiscono il contesto, dall'altro costituiscono una sorta di misura 'cautelativa' a cui Ovidio ricorre per non citare direttamente i culti 'orientali', che, come si è detto, non incontravano l'approvazione del princeps.

Nel v.79, incorniciato dal luogo e dall'oggetto della discussione (fora... amori), l'incidentale (quis credere possit?) si giustifica alla luce non solo della morale romana, ma anche della logica elegiaca ${ }^{22}$. L'attività legale e l'amore rappresentano realtà separate, estranee sia alla realtà sociale e alla biografia del poeta, sia all'elegia latina "che del rifiuto della carriera aveva fatto un assunto fondamentale della condizione del poeta amante". Ovidio stesso in $A m \cdot 1,15,1$ sgg. aveva sottolineato l'inconciliabilità dell'attività legale con l'amore; "qui invece la contiguità tra i due mondi è inevitabile, auspicabile" e l'incidentale "evoca la sorpresa del lettore e sottolinea la spregiudicatezza e l'ingegnosità del maestro" 23 . A conferma di tale novità precettistica è la strutturazione del verso: gli elementi che nell'esametro erano staccati - a sottolineare quasi, insieme alla sorpresa, la distanza tra il forum e l'amor - nel pentametro vengono singolarmente mescolati in sapiente alternanza di sostantivo e aggettivo; flamma (v.80) è in relazione naturalmente con il fuoco d'amore, nel suo aspetto passionale, che sembra aver la meglio sull'argutum forum: nella iunctura l'aggettivo rinvia non solo al frastuono degli alterchi e delle dispute giudiziarie, ma anche al brusio che anima queste piazze piene di folla ${ }^{24}$; diversamente da Prop. 4,1,133-134 tum tibi pauca suo de carmine dictat Apollo let vetat insano verba tonare Foro, infatti, nel contesto ovidiano la sonorità non costituisce un connotato fastidioso del foro, ma è segnale di vitalità di un luogo deputato all'inventio.

Dopo il distico che introduce la descrizione dei fori, nei vv.81-82 si menziona il forum Iulium, che con il tempio di Venus Genetrix fu inaugurato da Cesare nel 46 a.C. e qui viene indicato dalla descrizione della fontana adornata

${ }^{22}$ Viansino 1969,501 sottolinea come quis credere possit? che mette in luce il carattere inaspettato delle affermazioni successive, sia formula di passaggio, che in Virgilio, analogamente ad altre espressioni, viene rivolta a un ipotetico ascoltatore (Georg. 2,315 nec...quisquam persuadeat, così anche in 2,288 forsitan... quaeras). Ovidio ha riproposto una locuzione non dissimile nel v. 663 quis sapiens...non misceat; 3,7 dixerit e multis aliquis; 281 quis credat e 349 quis dubitet.

${ }^{23}$ Le parole sono di Labate 1984,86 che rinvia a Van Berchem 1948,137-154, a Steidle 1962,121 sgg. e a La Penna 1977,33 sgg.

${ }^{24}$ Lepiteto non va dunque inteso "in bad sense, 'schrill', 'wordy', come invece spiega Hollis 1977,48 . 
dalle statue delle ninfe Appiadi, dietro cui s'innalzava appunto il tempio di Venere Genitrice. Nel pentametro viene delineata la vivace immagine delle ninfe che spruzzano acqua, il cui getto è rappresentato dall'espressione aera pulsat e dal nesso allitterante aera...aquis.

All'indicazione del forum attraverso le sue coordinate topografiche, segue quella dello strapotere d'amore, che ha la meglio anche su quanti per mestiere sono preposti alla difesa altrui. I tre distici dedicati all'uomo di legge sono caratterizzati dalla stessa logica argomentativa, che regola la tecnica del verso: nell'esametro, la cui impronta didascalica è resa evidente dalla ripetizione del primo emistichio e dal ritmo cadenzato dei tre spondei, compare la constatazione della nuova, sconvolgente condizione (vv.83.85) e nel pentametro il parallelo con una realtà sconosciuta, travolta com'è dal vortice dell'innamoramento (84-86). Anche nell'ultimo distico dedicato all'uomo di legge rintracciamo l'identico procedimento, perché nell'esametro si fa riferimento alla realtà attuale che provoca il riso di Venere (riso di scherno, qual è, appunto, quello del vincitore nei confronti del vinto ${ }^{25}$ ), mentre nel pentametro è messa in luce ancora una volta la contrapposizione tra passato (qui modo patronus) e presente (nunc cupit esse cliens).

La stretta successione consultus Amori (v.83) stabilisce la relazione tra due mondi apparentemente difformi (quello della legge e quello dell'amore); subito dopo la cattura, gli effetti sono disastrosi perché il consultus diviene immediatamente prigioniero di Amore e proprio lui che di mestiere fa il difensore è incapace di difendersi. Se la sintomatologia, in primo luogo l'incapacità di esprimersi (cfr. v.85 desunt sua verba diserto ed e.g. Catull. 51,9 lingua...torpet), è quella tipica della malattia d'amore, l'effetto paradossale consiste ancora una volta nella specifica funzione di chi è succube di amore: chi non riesce a parlare, infatti, è proprio un disertus, al quale desunt sua verba. Il singolare innamoramento dell'uomo di legge è descritto perfettamente nelle sue fasi in progressione: se al momento della cattura viene fatto riferimento attraverso le consuete modalità espressive (cfr. v.83 capitur), il termine tecnico capere, però, ha qui un significato pregnante, perché nel linguaggio legale assume una specifica valenza giuridica, legata all'idea della trappola e dell'inganno, che è tipica del verbo soprattutto nella forma passiva ${ }^{26}$. Nel duplice impiego di cavere (v.84), inoltre, Ovidio rende esplicita l'ambiguità semantica prima

25 In bunc Venus ridet Pianezzola 1991,199, nel sottolineare che riso e scherzo sono prerogative della dea dell'amore, rinvia ad Hor. Carm. 1,2,33-34 Erycina ridens /quam Iocus circumvolat et Cupido e 2,8,13 ridet hoc... Venus.

${ }^{26}$ Cfr. Cic. Mur. 22 tu caves ne tui consultores...capiantur. Il consultus (iuris consultus o iure consultus) è l'esperto di diritto, distinto dal disertus citato nel v.85, che indica il patronus, ovvero l'avvocato difensore: la stessa associazione è in Am.1,13,21-22 nec tu consulto nec tu iucunda diserto e Cic. Brut. 148 consultorum alterum disertissimum, disertorum alterum consultissimum. 
implicita in capio; mentre, infatti, in cavit è possibile rintracciare una specifica valenza tecnico-giuridica ${ }^{27}$, l'immediatamente successivo cavet assume un significato generico ${ }^{28}$. L'impiego del vocabolario tipico della giurisprudenza romana è costante anche nel v.86, dove la res nova indica proprio "il caso senza precedenti" ${ }^{29}$. Nel v.88, infine, la successione delle argomentazioni è scandita dall'indicazione temporale all'inizio di ciascun emistichio (modo /...nunc), dall'individuazione della funzione alla fine (patronus.../ cliens) e dal gruppo verbale che precede l'avvenuta metamorfosi (cupit esse cliens).

Ieri come oggi gli spazi del divertimento e dello svago favoriscono gli incontri e rendono disinvolti i rapporti interpersonali; lo sa bene il praeceptor amoris, che, a partire dal v. 89 descrive l'altro luogo preposto all'inventio delle puellae da amare; il teatro, infatti, offre occasioni di caccia al di là di ogni aspettativa:

Sed tu praecipue curvis venare theatris:

haec loca sunt voto fertiliora tuo.

Illic invenies quod ames, quod ludere possis, quodque semel tangas, quodque tenere velis.

Ut redit itque frequens longum formica per agmen granifero solitum cum vehit ore cibum, aut ut apes saltusque suos et olentia nactae pascua per flores et thyma summa volant, sic ruit ad celebres cultissima femina ludos: copia iudicium saepe morata meum est. Spectatum veniunt, veniunt spectentur ut ipsae; ille locus casti damna pudoris babet (vv. 89-100).

La sezione delimitata dai vv.89-100 presenta una struttura chiara e lineare. L'avversativa iniziale (sed v.89) annunzia il nuovo messaggio precettistico; nel v.91 illic riprende e sottolinea il precedente haec loca, mentre il sistema delle correlative nei vv.93-97 (ut ...ut...sic) permette al lettore di seguire agevolmente la logica argomentativa dei praecepta. La porzione di versi, in cui è insistente l'impiego dell'iperbato (cfr. vv.90; 93-94; 97-98), può essere divisa in tre parti

${ }^{27}$ Cfr. ThlL III 636,72 sgg.

${ }^{28}$ Non è improbabile nel pentametro la suggestione di Cic. Fam. 7,6,2 (lettera indirizzata all'amico giurista Trebazio Testa) tu qui ceteris cavere didicisti, in Britannia ne ab essedariis decipiaris cavet. Per la successione ipse/sibi e sim., che compare sin da Ennio Scaen. 221 Jocelyn e nella poesia augustea in Her. 19,161 e in Verg. Buc. 8,108, cfr. ThlL VII 2,359,59 sgg. e Bömer 1976,139 (a Met. 6,493).

${ }^{29}$ Cfr. Voc.Iur.Rom. 5,107 che spiega l'espressione con Ulp. 15,1 in rebus novis constituendis. 
costituite ciascuna da 4 versi $^{30}$. Nella prima parte (vv.89-92), che contiene un preciso rinvio al momento dell'inventio (v.91 illic invenies), l'abbondanza delle specificazioni (cfr. v.90 haec; vv.91-92 quod ripetuto per quattro volte ${ }^{31}$ ), serve a persuadere con maggiore efficacia il destinatario dei praecepta; non a caso venari nel v.89 propone la metafora - frequente nella poesia elegiaca - dell'amore come caccia ${ }^{32}$, mentre ricompare l'impiego di $t u$ per conferire maggiore consistenza a un praeceptum, che è un espediente stilistico della letteratura didascalica. Nei vv.91-92, inoltre, la serrata successione dei verbi esprime le numerose possibilità d'amore offerte dal teatro; i due aspetti del legame erotico (il sentimento duraturo e la passione estemporanea) vengono delineati nell'esametro (quod ames, quod ludere possis) e ribaditi in schema chiastico nel pentametro (quod....semel tangas, quod...tenere velis).

Nella seconda parte (vv.93-96) il praeceptor illustra il suo punto di vista con due paralleli (formiche e api), che riecheggiano atmosfere georgiche frequenti in Ovidio ${ }^{33}$. La similitudine dei vv.93-97 non è né ardita né neutrale, perché i paralleli menzionati risalgono a due distinte similitudine virgiliane (Aen. 1,430-436 - che riformula la raffigurazione delle api in Georg. 4,162-169-e 4,401-407), unificate dal tertium comparationis, costituito dal movimento rapido e serrato di una pluralità di individui. A sua volta, però, Virgilio aveva ripreso Omero (Il. 2,87-93) e Apollonio Rodio (Argon. 4,1452-1456). Il paragone tra formiche e donne che affollano i teatri, inoltre, è particolarmente suggestivo: l'esametro delinea l'immagine vivace di un numero consistente di donne che attraversa il teatro in una lunga fila, mentre nel pentametro le formiche/donne hanno trovato la loro fonte di sostentamento. Di particolare interesse per i suoi risvolti ironici, inoltre, è il contrasto che si crea tra le formiche e gli animali di stazza maggiore, a cui induceva a pensare l'impiego di venare nel v.89.

Il secondo paragone propone un'immagine in contrasto con quella fornita nel primo: lì le formiche / donne ordinatamente e, sembra quasi di capire, in base ad uno schema ben determinato, vanno in cerca di cibo / uomini; si trasformano, quindi, in predatrici, mentre gli uomini divengono, loro malgrado, prede; nel secondo paragone, invece, c'è un movimento apparentemente caotico e disordinato (il volo di fiore in fiore, di balza in balza), che, in realtà, è finalizzato alla conquista amorosa. Nei vv.97-98 l'analogia tra le formiche e le api e l'affollarsi frenetico delle donne a teatro è determinata dall'impiego di ruere. L'intervento dell'esperienza personale (v.98 copia iudicium saepe morata meum est) conforta ulteriormente la veridicità dell'affermazione.

\footnotetext{
${ }^{30}$ La schematizzazione è proposta da Miller 1996-97,333-339.

${ }^{31}$ Lespressione curvum theatrum è anche al v.497; Am. 2,2,26 e Pont. 2,4,20.

${ }^{32}$ La metafora è attestata anche nel v. 263; 2,2.406; Am. 1,2,19; 1,8,69; Prop. 2,32,20; 3,8,37 e Tib. 1,6,5-6: cfr. Fedeli 1985,299.

${ }^{33}$ Cfr. Leach 1964,142-154.
} 
Nel distico conclusivo, la sententia, che, caratterizzata dalla struttura a chiasmo di due coppie verbali ${ }^{34}$, suggella le argomentazioni precedentemente sviluppate, garantendone l'invariabilità nel tempo, in realtà non comunica un messaggio di univoca referenza; l'impiego di spectatum, infatti, è anfibologico, in quanto il termine può significare sia il guardare gli uomini, sia l'assistere allo spettacolo; un riecheggiamento dell'espressione è in Met. 9,461-462 paulatim declinat amor, visuraque fratrem / culta venit nimiumque cupit formosa videri.

Che agli occhi del poeta il teatro assuma un'importanza determinante come luogo di seduzione risulta evidente dalla ripresa di analoghi praecepta nei vv.497-504:

Nec sine te curvo sedeat speciosa theatro:

quod spectes, umeris adferet illa suis.

Illam respicias, illam mirere licebit, multa supercilio, multa loquare notis;

et plaudas aliquam mimo saltante puellam

et faveas illi, quisquis agatur amans.

Cum surgit, surges; donec sedet illa, sedebis. arbitrio dominae tempora perde tuae (vv. 497-504).

Come già nella precedente fase dell'inventio (vv.89 sgg.), il praeceptor mette a fuoco l'importanza del posto in cui accomodarsi. In questo caso il forte monito iniziale (nec sine te... sedeat speciosa) mira a non rendere vani i tentativi dell'innamorato di mantenere l'esclusiva sulla donna prescelta. La triplice allitterazione (v.497 sine... sedeat speciosa) non lascia dubbi sull'importanza del praeceptum, a cui non risulta estraneo il riverbero etimologico di speciosa in spectes nel v.498. L'avvertimento del poeta è inequivocabile: il corteggiatore dovrà esser spettatore delle 'performances' della puella, più che di quelle sceniche; poi, con cadenze dalla chiara impronta proverbiale, Ovidio sottolinea come la donna costituirà l'oggetto esclusivo della sua attenzione.

Le indicazioni precettistiche insistono sul motivo del 'vedere', che qui diviene strumento di indagine e al tempo stesso peculiare canale di comunicazione; nel primo caso il respicere è non solo in linea con la tattica dell'obsequium (osservare quasi con adorazione la propria donna), ma anche con la particolare sistemazione delle donne che a teatro occupavano le file più alte e quindi si trovavano alle spalle degli uomini. Ovidio non abbandona il motivo del mirari, la cui importanza deriva anche dalla sua valenza 'strumentale': nel v.500, infatti, la 'vista' è fondamentale per decodificare il muto linguaggio fatto

${ }^{34}$ Un simile giuoco di diatesi si rintraccia in Plaut. Poen. 337-338 sunt illi aliae quas spectare ego et me spectari volo / qui lubet spectare turpis, pulchram spectandam dare e in Tert. De spect. 25,3 nemo denique in spectaculo ineundo prius cogitat nisi videri et videre. 
di gesti, di ammiccamenti e di segnali segreti, in una singolare commistione dei codici di comunicazione (la vista e la parola) ${ }^{35}$.

Solo per lo spazio di un distico (vv.501-502) e in modo del tutto inaspettato, le formulazioni del praeceptor si spostano dalla puella alla scena, con un realistico riferimento al mondo dello spettacolo coevo all' $\mathrm{Ars}^{36}$. Il cambiamento di prospettiva prevede un intervento concreto del corteggiatore, che, con l'applauso, dovrà mostrare tutto il suo apprezzamento per lo spettacolo del pantomimo; nel pentametro, però, la mutata prospettiva scenica si riconcilia con le finalità dell'Ars, perché l'entusiasmo del plaudente amator dovrà gratificare chiunque sostenga la parte dell'innamorato. Si capisce, allora, che l'apprezzamento espresso con così grande trasporto dal corteggiatore è finalizzato alla felice riuscita dell'opera di seduzione, perché a suscitare gli applausi non sarà certo l'ottima qualità della 'performance', ma il personaggio messo in scena, l'amans, appunto. Nella consueta prospettiva ovidiana, in cui largo spazio ha il giuoco delle finzioni, sarà proprio la rappresentazione della vicenda d'amore, con i suoi contenuti e con le sue trame, a consentire al corteggiatore una tacita, ma significativa comunicazione con la sua donna. La sottile relazione tra la messinscena dell'aspirante amator e quella dello spettacolo a cui assiste viene abilmente sottolineata dai vv.501-502 plaudas... puella / agatur amans, sebbene con la specificità dello scopo da perseguire contrasti l'indeterminatezza nel definire i personaggi della scena (aliquam e quisquis).

Dopo aver preso in considerazione l'attore che impersona l'amante ${ }^{37}$, il discorso torna a coinvolgere la domina. Si fa infatti riferimento all'obsequium, atteggiamento indispensabile che l'amante deve mostrare anche attraverso una scaltra sincronia di gesti. Le azioni comuni sono essenzialmente quelle legate alla permanenza nel teatro e ai movimenti della puella; l'omogeneità semantica (v.503 surgit, surges... sedet... sedebit) traduce alla perfezione il totale annullamento di personalità dell'amante, che mira a conquistare la donna. Il tempo dell'amante, dice Ovidio, coincide con quello dell'amata, anzi deve essere 'consumato' (v.504 tempora perde) ad assecondarne i desideri: arbitrio dominae in apertura del v.504 dà priorità assoluta ai capricci di chi a buon diritto ormai può configurarsi come padrona (domina) del cuore - oltreché del tempo - dell'amante.

\footnotetext{
${ }^{35}$ Per l'uso dei linguaggio alternativi quelli verbali cfr. Am. 1,4,19-20, McKeown 1989,85 e Dimundo 2000,55.

${ }^{36}$ L'allusione è qui al pantomimo, azione scenica rappresentata da un mimo, che danzando interpretava le varie parti del copione recitato da un attore (praeco) con l'orchestra e il coro; al mimo sembra rifarsi Ovidio in Trist. 2,497-500, in cui individua tale forma di spettacolo come il più immorale tipo di letteratura rispetto a qualunque cosa egli abbia mai scritto.

${ }^{37}$ Sul ruolo 'scenico' dell'amante cfr. anche Solodow 1977,119.
} 
L'altro luogo preposto all'inventio è lo spazio riservato nel circo alle corse dei carri, la cui influenza negativa sugli uomini è spesso deprecata dagli scrittori cristiani $^{38}$. Diversamente dal teatro, nel circo non c'era separazione dei sessi nei posti a sedere e, di conseguenza, più numerose erano le occasioni della 'caccia':

Nec te nobilium fugiat certamen equorum: multa capax populi commoda Circus habet.

Nil opus est digitis per quos arcana loquaris, nec tibi per nutus accipienda nota est.

Proximus a domina, nullo probibente, sedeto, iunge tuum lateri qua potes usque latus.

Et bene, quod cogit, si nolis, linea iungi, quod tibi tangenda est lege puella loci (vv. 135-142).

Una situazione analoga a quella descritta nei vv.135-142 dell'Ars è in $A m$. 3,2: gli spunti in comune sono a tal punto numerosi che il contesto dell'Ars è stato considerato "a pallid reworking of the brilliant and delightful $\mathrm{Am}$. 3,2"39. Diverse, tuttavia, sono le forme e le finalità delle due redazioni, perché se nell'elegia è possibile scorgere un equilibrato alternarsi di situazioni reali e di fantasie amorose, nell'Ars l'impostazione didascalica dà ai versi un tono diverso, perché rigidamente prescrittivo ${ }^{40}$.

Se il v.135 riecheggia chiaramente Am.3,2,1 non ego nobilium sedeo studiosus equorum, il pentametro successivo - in cui è rilevante l'impiego del doppio iperbato e dell'allitterazione polisillabica - ricalca Am.3,2,20 haec in lege loci commoda Circus habet. Il rinvio qui è al Circo Massimo, che, di origine regia, e più volte sottoposto a interventi di ammodernamento, era stato ricostruito al tempo di Cesare; collocato fra l'Aventino e il Palatino, in epoca augustea aveva una capienza di circa 60.000 spettatori.

Il tema della 'semplicità' della 'caccia' nel Circo nei vv.137-138 viene introdotto attraverso il riferimento alla gestualità delle dita e del capo per inviare messaggi segreti. La coordinazione negativa nil opus est posta all'inizio vuole subito escludere decisamente ogni possibilità ed è ovvio che si trovi spesso in incipit ${ }^{41}$; l'impiego di arcanus, inoltre, ha un raffinato doppio senso, perché da

${ }^{38}$ Cfr. e.g. [Cyprian.] De spect. 5 momoriter totam equini generis sobolem compuntantem, [...] quam vana sunt ipsa certamina, lites in coloribus, contentiones in curribus, favores in honoribus, gaudere quod equus velocior fuerit, maerere quod pigrior, annos pecoris computare, consules nosse, aetates discere, prosapiam designare, avos ipsos atavosque memorare.

${ }^{39}$ L'espressione è di Hollis 1977,58, che segue Thomas 1969,710-724.

${ }^{40}$ La rivalutazione del contesto dell'Ars si deve a Andronica 1969,35 - che sottolinea la raffinatezza dei continui rinvii alla descrizione elegiaca - e a Merkle 1983,135-145, che fa una dettagliata analisi fra i due contesti.

${ }^{41} \mathrm{Cfr}$. anche con lievi variazioni 2,162; Am. 1,2,21; Her. 20,187; Met. 1,279; 2,785; 7,215; 10,565; 14,24; Fast. 4,813.926; Trist. 5,14,41; Pont. 3,1,113; 4,13,8 e Radford 1923,240. 
una parte si carica di un significato religioso ${ }^{42}$, dall'altra ha una chiara valenza erotica, come anche e in 2,596 excipite arcana verba notata manu. I vantaggi del luogo sono gradualmente illustrati nei vv.139-142: dapprima è messa in rilevo l'opportunità di prendere posto accanto alla donna, anzi il più vicino possibile (proximus), perché nessuno lo può impedire (il tono imperiosamente didascalico del distico è caratterizzato soprattutto dall'imperativo futuro - tipico della lingua giuridica delle origini e comune alla poesia didascalica ${ }^{43}$ - immediatamente seguito dall'imperativo presente nel pentametro). Successivamente lo scopo del praeceptum (proximus a domina), apre il distico 139-140, mentre gli imperativi (sedeto / iunge) segnano rispettivamente la clausola dell'esametro e l'incipit del pentametro; per di più iunge impartisce un nuovo insegnamento, che va nel senso di una maggiore concretezza (iunge tuum...latus). Nel distico successivo le parole del praeceptor divengono una sorta di costrizione imposta dal luogo stesso (cogit...linea), che rende inevitabile il contatto, anche se non lo si desiderasse (cfr. il fortemente ironico si nolis). La stretta vicinanza con l'altro sesso, anzi, si configura paradossalmente come doverosa osservanza di una legge, la cui autorevolezza scaturisce dall'approvazione della collettività (lege...loci): il duplice nesso allitterante (tibi tangenda...lege...loci) sottolinea l'importanza del praeceptum.

Nelle manovre seduttive più o meno scoperte la conversazione ha un ruolo determinante: non sorprende, allora, che Ovidio elargisca al suo allievo circostanziati praecepta relativi agli argomenti di un amabile dialogo:

Hic tibi quaeratur socii sermonis origo et moveant primos publica verba sonos.

Cuius equi veniant, facito, studiose, requiras nec mora, quisquis erit, cui favet illa, fave.

At cum pompa frequens caelestibus ibit eburnis, tu Veneri dominae plaude favente manu; utque fit, in gremium pulvis si forte puellae deciderit, digitis excutiendus erit:

et si nullus erit pulvis, tamen excute nullum: quaelibet officio causa sit apta tuo.

Pallia si terra nimium demissa iacebunt, collige et inmunda sedulus effer bumo:

${ }^{42}$ La medesima valenza connota il vocabolo in Met. 2,639.755; Fast. 3,143: cfr. ThlL IV 435,16 .

${ }^{43}$ Cfr. e.g. Verg. Georg. 2,197.408 sgg., oltre alle leggi delle dodici tavole e ai trattati ciceroniani (in particolare il De legibus). Per nullo probibente (e sim.) cfr. Am. 2,10,21; Her. 1,89 nullis probibentibus; Rem. 537 i, fruere usque tua nullo probibente puella; Met. 2,202 nullo... inhibente; 14,769 nulla...obstante; Pont. 4,5,15 copia nec vobis nullo probibente videndi e McKeown $1998,211$. 
protinus, officii pretium, patiente puella

contingent oculis crura videnda tuis (vv.143-156).

Nel v. 143 l'incipitario bic è in relazione non solo con lo spazio, ma anche col momento opportuno; l'esigenza di 'attaccare discorso' è sottolineata dalla formula tibi quaeratur, mentre le allitterazioni (socii sermonis e primos publica) evidenziano l'opportunità dell'approccio verbale. Il senso di publica verba (v.144) viene chiarito nel distico successivo, in cui nell'esametro incontriamo nuovamente l'impiego dell'imperativo futuro (facito), mentre sulla pentametro il tono prescrittivo è dato dall'imperativo fave collocato nella chiusa del verso. In realtà l'approccio verbale è confinato solo nel v.143, perché i successivi praecepta riguardano piuttosto atteggiamenti ed attenzioni che hanno la puella come destinatario privilegiato. Sempre nell'ambito del discorso sulla passione per le corse dei cavalli, Ovidio suggerisce opportunamente al suo allievo di fare il tifo, senza esitazione alcuna (v.146 nec mora), per lo stesso cavaliere per cui tifa la fanciulla.

Alla processione (pompa) che precedeva l'inizio delle corse nel Circo si fa riferimento nei vv.147-148; in tale circostanza sfilavano su portantine le statue degli dèi ed ogni spettatore rivolgeva il proprio applauso alla personale divinità protettrice; non a caso qui l'amator omaggia calorosamente (favente manu) la dea dell'amore, come già in Am. 3,2,43-44 sed iam pompa venit, linguis animisque favete; / tempus adest plausus: aurea pompa venit $\mathrm{e}$ nei vv.55-56 nos tibi, blanda Venus... / plaudimus ${ }^{44}$.

L'approccio può divenire via via sempre più concreto, tanto che addirittura si potrà toccare la fanciulla senza destare sospetti; l'atto dello scuotere la polvere dal vestito della donna - il solerte officium dell'amante ha i tratti di una precisa imposizione (v.150 digitis excutiendus erit) - se apparentemente si configura come espressione concreta dell'obsequium dell'innamorato, in realtà consente all'amante di 'sondare concretamente il terreno', per verificare l'altrui volontà di avviare un rapporto d'amore. Nel v.151, in cui si insiste sul pretesto di scuotere la polvere dal vestito della donna che si intende conquistare, se è evidente la ripresa di Am. 3,2,41-42 dum loquor, alba levi sparsa est tibi pulvere vestis / sordide de niveo corpore, pulvis, abi, al tempo stesso Ovidio reimpiega la terminologia dei versi precedenti (pulvis, excutio), mentre il poliptoto di nullus apre e chiude il verso. Tale pretesto (si nullus erit pulvis, tamen excute nullum) costituisce un elemento di novità rispetto alla versione degli Amores, così che il v. 151 "riporta l'atteggiamento elegiaco alla dimensione propria dell'Ars,

${ }^{44}$ Con caelestibus...eburnis ci si riferisce alle statue di avorio della divinità e l'impiego del prezioso materiale non risulta sorprendente, perché se ne trova conferma in Tac. Ann. 2,83,2; Suet. Tit. 2 e Cass. Dio. 43,45,2. 
cioè alla finzione come strategia della conquista" ${ }^{45}$. Nel pentametro successivo, infine, la massima riassume gli atteggiamenti ossequiosi dell'aspirante amator, che verranno resi espliciti anche attraverso altri comportamenti tipici dell'innamorato; a confermarlo sta la presenza di sedulus (v.154) che, analogamente a sedulitas e in riferimento a 'qui adsidua praesentia officiis, curis, placere laborat ' ${ }^{46}$ è spesso utilizzato da Ovidio nell' $A r s^{47}$. Il giovane, infatti, avrà cura di sollevare dal suolo il lembo del mantello insudiciato e come premio del suo zelo otterrà la riconoscenza della fanciulla, che non opporrà resistenza: lo fa capire il nesso allitterante patiente puella nel v.155, in cui le figure di suono e di ritmo danno consistenza alle argomentazioni. I numerosi dattili, inoltre, accelerano il movimento del verso, quasi a rendere la simultaneità delle azioni compiute dall'amans, mentre la presenza di officium, già usato nel v.152, sottolinea l'intenzionale uniformità delle situazioni ${ }^{48}$. Come premio ulteriore del suo obsequium, l'aspirante amator avrà anche la possibilità di gettare occhiate furtive ed indagatrici alle gambe della fanciulla (cfr. v.156 oculis... videnda tuis in cui, attraverso l'amplificazione dell'immagine si dà particolare rilievo al motivo del 'vedere'). Ancora una volta il modello va ricercato in $\mathrm{Am}$. 3,2,25-32, dove l'esemplarità mitica che nobilita la situazione personale segna decisamente lo scarto tra le due versioni.

Il praeceptor si sofferma ad indicare altri piccoli accorgimenti finalizzati alla conquista amorosa nel circo: l'amante deve fare attenzione affinché un rude spettatore non importuni con un atteggiamento incauto ed eccessivamente disinibito l'agognata puella:

Respice praeterea, post vos quicumque sedebit, ne premat opposito mollia terga genu.

Parva leves capiunt animos: fuit utile multis pulvinum facili composuisse manu; 160 profuit et tenui ventos movisse tabella et cava sub tenerum scamna dedisse pedem (vv. 157-162).

Anche nei vv.157-158 il riferimento è ad Am. 3,2,23-24 tu quoque, qui spectes post nos, tua contrahe crura / si pudor est, rigido nec preme terga genu. Il disprezzo del precettore, insito nell'indefinito dell'esametro ${ }^{49}$, è reso esplicito nell'iperbato opposito...gen $u^{50}$, che incornicia i mollia terga della fanciulla, mentre l'incipitario ne premat esprime per intero il biasimo nei confronti di

\footnotetext{
${ }^{45}$ Sono parole di Pianezzola 1991, 206.

${ }^{46}$ Cfr. Pichon 1902,260.

${ }^{47}$ Cfr. 377.384; 2,334.

${ }^{48}$ Per pretium in contesti sessuali si rinvia ad Am. 2,1,34; 5,62 e 8,21-22.

${ }^{49}$ Per il generico quicumque cfr. 2,701-702; Rem. 371; Trist. 3,11,63 e Hor. Ep. 15,17.

${ }^{50}$ Opponere genu ricompare in Met. 5,383 e 12,347: cfr. ThlL IX 2,766, 38-39.
} 
un tale atteggiamento. Il distico 159-160 ha l'impostazione argomentativa di una massima che dà maggiore rilievo al praeceptum successivo; a detta di Ovidio quanto è stato illustrato fino a questo punto, e, naturalmente, i praecepta che seguiranno, hanno l'apparente carattere di cose di poco conto (parva). Anche la terminologia è in linea con l'impostazione didascalica del contesto, come indica soprattutto l'impiego dell'espressione utile fuit, variata nel v.161 dall'incipitario profuit: l'Ars, dunque, si presenta come una silloge metodologica dalla comprovata efficacia ${ }^{51}$. Nell'ultimo omaggio alla puella (vv.161-162), che riecheggia ancora Am. 3,2,37-38 vis tamen interea arcessere ventos / quos facies nostra mota tabella manu, di particolare ricercatezza è la tecnica dell'aggettivazione: la tabella, che indica probabilmente una comune tavoletta per scrittura, qui usata come un improvvisato ventaglio ${ }^{52}$, è tenuis, epiteto perfettamente in linea con la terminologia elegiaca; nel v.162 il pes della fanciulla non può che essere tener, secondo un raffinato impiego dell'impiego dell'epiteto che rinvia inevitabilmente ai mollia terga del v.158.

Altre occasioni di sicura conquista sono i giuochi gladiatori, che a Roma godevano di una consolidata tradizione (264 a.C.) e all'inizio erano organizzati nel Foro (prima Boario, poi Romano). A Roma il primo anfiteatro in pietra risale al 29 a.C., ad opera di Statilio Tauro ${ }^{53}$; ma, a stare alle parole del poeta, all'epoca di Ovidio i gladiatori continuavano ad esibirsi nel Foro.

Hos aditus Circusque novo praebebit amori
sparsaque sollicito tristis harena foro.
Illa saepe puer Veneris pugnavit harena
Et, qui spectavit vulnera, vulnus habet:
dum loquitur tangitque manum poscitque libellum
et quaerit posito pignore, vincat uter,
saucius ingemuit telumque volatile sensit
et pars spectati muneris ipse fuit (vv.163-170).

Nel distico introduttivo, dalle epiche cadenze, grazie al nesso -que -que (= $-\tau \varepsilon-\tau \varepsilon)$, evidente è il contrasto tra l'esametro - dove si fa semplice riferimento all'opportunità di nuovi incontri che il circo offre (aditus Circus...novo praebebit amori) - e il pentametro, in cui la sapiente costruzione chiastica (abaab) concentra il nesso tristis harena nell'iperbato sollicito... foro. Il contesto, per più, è

${ }^{51}$ Come sottolinea Labate 1984,173-174 "a differenza del galantuomo, l'amante elegiaco non dovrà rinunciare al privilegio riconosciuto dalla techne, quello di poter utilizzare, in piena libertà, tutte le risorse di sua competenza, per il conseguimento dell'utile, cioè dello scopo istituzionale dell'Ars, stessa [...]; utilis, iuvare, nocere, prodesse, vincere, sono perciò parole frequenti nel poema”.

${ }_{52}^{5}$ Sul diminutivo cfr. Gow 1932,153 e n.3.

${ }^{53}$ Cfr. N. Purcell, Forum Romanum (The Republican Period), LTVR II (1995) 331-2. 
reso fortemente patetico dagli aggettivi (sollicitus / tristis), che, detti solitamente di sentimenti umani, sono qui in riferimento a realtà inanimate (forum/harena).

In una singolare commistione di ruoli e di funzioni ${ }^{54}$, il circo si trasforma nel campo di battaglia del puer Veneris. La stessa harena dei combattenti gladiatori diviene qui luogo di scontro di Cupido, che ha come antagonista lo spettatore stesso: nel v.165 con un iperbato a cornice la definizione del terreno di combattimento occupa gli estremi del pentametro (illa...harena), mentre il protagonista della singolare tenzone (puer Veneris) è collocato al centro del verso. Il ribaltamento dei ruoli viene descritto nel pentametro, dove chi è venuto a guardare le ferite altrui diviene vittima dei colpi inferti da Cupido. L'espressione vulnus habet che chiude il distico segna l'avvenuto innamoramento, poiché determina la ferita e dunque la malattia d'amore. Colpito dalle frecce di Cupido, lo spettatore si lascia andare ad atteggiamenti inconsulti e la serrata successione di verbi nei vv.167-169 sottolinea la frenesia del novello innamorato. Se il distico 167-168, in cui al nesso -que -que si affianca l'omeoteleuto ad incastro (manum...libellum), costituisce una pausa nella descrizione della sintomatologia dell'innamorato trafitto, quello successivo (vv.169-170) riporta considerazioni di ordine generale sul malato d'amore ${ }^{55}$; esso, inoltre, è tutto costruito su materiale epico, utilizzato in una coordinazione polisindetica. In tale prospettiva risultano fortemente connotativi sia l'epiteto saucius che, di origine enniana, ricorre per ben 7 volte nell' Eneide ${ }^{56}$, sia la consistente presenza dattilica che accelera il ritmo del verso. La 'iunctura' saucius ingemuit, inoltre, si impone come una chiara ripresa properziana: l'immagine di Milanione che saucius Arcadiis rupibus ingemuit (Prop.1,1,14) costituisce un nobilissimo paradigma dell'innamorato che, colpito dalle frecce di Amor, non trattiene i suoi lamenti; tuttavia lo scarto tra le due situazioni (in Ovidio la ferita che provoca lamenti è di un innamorato la cui condizione sentimentale è del tutto opposta a quella dell'amante properziano) determina un forte quoziente di ironia ${ }^{57}$.

Dal v.171 ha inizio l'analisi delle cerimonie pubbliche, con il riferimento alla naumachia (vv.171-176), che, con uno spettacolo grandioso realizzato da Augusto nel 2 a.C., per la festa inaugurale del tempio di Marte Ultore, a rievocazione della battaglia navale di Salamina, costituì un momento di forte richiamo a Roma:

${ }^{54} \mathrm{Su}$ tale sovrapposizione funzionale cfr. Solodow 1977,126 n.34.

${ }^{55}$ Il diminutivo libellus (v.167) su cui si rinvia a Gow 1932,155 e n.1, qui indica il programma dello spettacolo con l'elenco dei gladiatori: cfr. anche Cic. Phil 2,97 gladiatorum libelli e Pollione (Scrip. Hist. Aug.), Claud. 5,5 libellus munerarius.

${ }^{56}$ Cf. Fedeli $1985,77$.

${ }^{57}$ Galasso1995,218 sottolinea che ingemesco è un termine patetizzante, frequente nelle Metamorfosi ma raro nell'elegia erotica. 
Quid, modo cum belli navalis imagine Caesar

Persidas induxit Cecropiasque rates?

Nempe ab utroque mari iuvenes, ab utroque puellae

venere, atque ingens orbis in Urbe fuit.

Quis non invenit turba, quod amaret, in illa?

Eheu, quam multos advena torsit amor! (vv.171-176).

Il linguaggio è convenzionale: da un lato, infatti, nempe che apre il v.173 può intendersi come una reminiscenza lucreziana ${ }^{58}$, dall'altro l'espressione $a b$ utroque mari...ab utroque ${ }^{59}$ è stereotipata per indicare la larga affluenza di gente; in questo caso il riferimento al loro codice di età (iuvenes/puellae) è naturalmente obbligatorio, in linea con il carattere divulgativo e specificatamente didattico dell'opera. Nell'espressione ingens orbis in Urbe fuit, inoltre, rintracciamo la giustapposizione orbis / Urbis frequente negli encomia di Roma ${ }^{60}$. La domanda retorica del v.175 presuppone una risposta affermativa (in quella circostanza tutti hanno trovato la donna da amare) tanto più che l'affluenza della gente da ogni parte del mondo aveva i caratteri di una vera e propria turba. Accanto alla condizione di fondo dell'amans (l'essere appunto innamorato), Ovidio non può passare sotto silenzio che la conseguenza principale di tale condizione è il tormento d'amore: lo fa capire l'impiego di torquere (v.176), che rinvia immediatamente al motivo dei tormenta in materia erotica ${ }^{61}$. Lintervento innovativo di Ovidio, che ricollega la gnome alla specificità del contesto, va rintracciato nell'aspetto particolare di quell'amor, che si caratterizza come advena: i termini più significativi del resoconto ovidiano occupano l'ultima sezione del distico e il carattere peculiare del rapporto d'amore è strettamente legato alla condizione sentimentale stessa (torsit amor ${ }^{62}$ ).

L'esame dei praecepta ovidiani relativi all'inventio consente di scorgere nell'entusiastica rassegna dei luoghi più adatti alla cattura d'amore una vera e propria topografia celebrativa di Roma, che - si capisce bene - per Ovidio è anche la città più bella del mondo. Quell'ambiente ricco di monumenti e di luoghi di svago, testimonianza concreta del fasto architettonico che, sponsorizzato da

${ }^{58}$ Cfr. e.g. 1,$385 ; 2,487.908 ; 4,1173-74$.

${ }^{59}$ A giudizio di Brandt 1902,19 l'espressione ab utroque mari è in riferimento al mare superum e inferum, cioè all'Adriatico e al Tirreno, come analoghe espressioni in Met. 1,338; 15,829-830; Pont. 1,4,30 e Cic. Att. 9,5,1. Tali identificazioni geografiche, tuttavia, sarebbero troppo limitative, soprattutto in riferimento a ingens orbis (v.174). Per l'anafora di uterque cfr. il v.18; Am. 1,10,31; 2,14,31; 3,2,5-6; Med. 71-72; Rem. 711-712; Met. 2,294-95 e Fast. 5,139.

${ }^{60} \mathrm{Cfr}$. in particolare Rut. Nam. De reditu suo 1,66 urbem fecisti quod prius orbis erat; Otto 1890,358-59 s.v. urbs e Bréguet 1969,140-152.

${ }^{61}$ Per torquere in questo senso cfr. Prop. 3,6,39 me quoque consimili impositum torquerier igni.

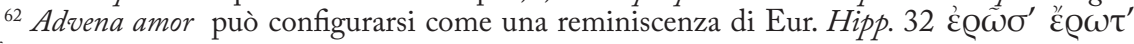

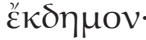


Augusto, porterà alla realizzazione dell'aurea Roma, costituisce la dimensione mondana dell'elegia ovidiana, il palcoscenico suggestivo calcato da chi, come l'aspirante amator, è disposto a recitare un copione scritto da altri ed è ben lieto di farlo in una preziosa scenografia. 


\title{
Ovídio, o POETA NA CIDAde
}

\author{
Carlos Ascenso André \\ Universidade de Coimbra \\ Centro de Estudos Clássicos e Humanísticos
}

Forçado a optar entre o amor e o cumprimento da missão, Eneias, que de herói parecia ter pouco (seria, até, a pálida imagem de um herói, no mais genuíno sentido épico), optou pela missão, ainda que a contragosto, e menosprezou os direitos da paixão, apesar de ser filho de Vénus.

Rómulo e Remo, os míticos fundadores de Roma, nada ficam a dever ao amor no seu nascimento, segundo a tradição, já que parecem nem ter mãe: são obra da amamentação das tetas de uma loba.

Estes são dois dos exemplos apresentados por Pierre Grimal, para documentar a escassa importância que os Romanos dariam ao amor ${ }^{1}$. Mas, não obstante esta visão de alguém que escolheu, algo contraditoriamente, para título sugestivo do seu livro, L'amour à Rome, e não por acaso, a verdade é que o amor ocupa lugar central na sociedade romana. Dito de outra forma, Roma era, entre outras coisas, a cidade do amor.

Quem o afirma é, desde logo, Ovídio, o poeta, por excelência, do amor:

\section{Mater in Aeneae constitit urbe sui.}

A mãe estabeleceu morada na cidade do seu Eneias.

(Ars, 1.60)

Ou, como diz em outro lugar:

At Venus Aeneae regnat in urbe sui.

É Vénus que reina na cidade do seu Eneias.

(Amores, 1.8.42)

Já há muito isso acontecia, desde os tempos em que a cidade era uma espécie de "feira do sexo", ou seja, em que a venda dos prazeres do corpo ocupava lugar de relevo no quotidiano ${ }^{2}$. A leitura, aliás, de ambos os autores citados, Robert e Grimal, acrescida da de um outro estudioso da sociedade romana e da literatura que nela se produziu, Paul Veyne, deixa bem claro o lugar central que o amor ocupava em Roma. Esse será, de resto, o motivo por que os poetas de amor

\footnotetext{
${ }^{1}$ Grimal 1995 14-23.

${ }^{2}$ Robert 1997 152-153.
} 
latinos alcançaram tão grande sucesso entre os seus contemporâneos - porque souberam traduzir em palavras uma verdade da alma romana ${ }^{3}$.

De entre todos, porém, Ovídio será o poeta do amor por excelência. Expliquemo-nos: ao contrário de Propércio, de Tibulo, de Catulo, Ovídio não é um poeta fora da cidade ou à margem da cidade. É, isso sim, um poeta na cidade. Os outros centram-se, por via de regra, em duas figuras, ou seja, o par amoroso de que ele, poeta, é, assumidamente, um dos parceiros. Ainda que possa não ser real esse amor assim cantado $^{4}$, o que não vem agora ao caso, os seus poemas circunscrevem-se à vida de duas personagens, o poeta amante e sua amada, e cerram-se em torno dessa mesma vida. Dito por outras palavras, é como se Propércio, Tibulo, Catulo se isolassem da cidade, para se enclausurarem no mundo restrito dos seus amores, porventura imaginários.

Ovídio, ao contrário, celebra o amor enquanto tal e a cidade de que ele, amor, é protagonista. Por isso, canta a cidade; porque canta o amor no contexto da cidade, da sua cidade. Os retratos que de seus versos emergem, as mais das vezes traçados a linhas firmes e certeiras, os episódios que descreve, as relações que vai desenhando, os preceitos que enumera e encaixa num edifício didático de rara arquitetura, tudo isso faz parte da cidade e reflete-a. E, mais do que isso, intervém nela, no seu quotidiano, nas mesmas relações entre pessoas, no vai-e-vem de homens e mulheres, nos encontros e desencontros de sentimentos ou de prazeres, nas fantasias e nas experiências reais. Intervém, ao mesmo tempo que retrata.

Comecemos exatamente por aí, ou seja, por esse olhar que, ao mesmo tempo que esboça um quadro da sua cidade, nela pretende agir, através da palavra e do poema. Ovídio é, como ele próprio se define, um poeta do amor lúdico; o que ele celebra é o amor e o prazer, a relação estreita entre um e outro, já que o primeiro, se não comportar o segundo, não o seduz, antes deliberadamente ele o enjeita. Ora, Roma será, pretensamente, o território de um e outro, onde o amor é vivido em "rede", como sustenta Paul Veyne , e onde se troca de parceiro ao ritmo de um por noite.

Mas há uma feição desse mesmo amor que o poeta enjeita e contesta de forma desabrida: o amor comprado. $\mathrm{Na}$ cidade onde a prostituição parece ter-se estabelecido como prática corrente, Ovídio rema contra a corrente e rejeita tal prática e quanto lhe está associado.

O motivo primeiro que indica é simples: amor comprado não dá prazer, regra essencial, como se sabe, no amor ovidiano. A mulher objeto da sua sedução e do seu desejo deixou de o cativar, por isso mesmo:

\footnotetext{
${ }^{3}$ Robert 1997 202-203. Vd., também, Griffin 1976.

${ }^{4}$ Veyne 1983 9-23.

${ }^{5}$ Veyne 198395.
} 
Cur sim mutatus? - quaeris. Quia munera poscis;

haec te non patitur causa placere mibi.

Porque assim mudei? - perguntas. Porque reclamas uma paga;

esse motivo não consente que possas dar-me prazer.

(Amores, 1.10.11-12)

O interesse, nascido de coração perverso, deixou a sua mácula na formosura, assim contrariando a essência do amor, cujo deus, de resto, como indica a sua nudez, é adepto da transparência. Acresce, além disso, uma razão de fundo: prazer e obrigação não convivem bem um com o outro. E a cortesã, submissa aos interesses do alcoviteiro, é por obrigação que entrega o corpo:

et, quod uos facitis sponte, coacta facit.

e aquilo que vós fazeis de vontade, ela é por obrigação que o faz.

(Amores, 1.10.24)

Nesse particular, o ser humano tem muito a aprender com os animais, bem mais sensíveis e delicados: nem a égua cobra ao cavalo os seus favores sexuais, nem a vaca ao boi, nem o carneiro à ovelha:

Sola uiro mulier spoliis exultat ademptis;

sola locat noctes; sola locanda uenit

et uendit quod utrumque inuat, quod uterque petebat, et pretium, quanti gaudeat ipsa, facit.

Só a mulher rejubila com os despojos que arrancou a um homem; só ela aluga as noites; só ela se apresta a alugar-se e vende aquilo que a um e outro dá prazer, aquilo que um e outro desejam, e estabelece o preço à medida do seu próprio gozo.

(Amores, 1.10.29-32)

Sublinhe-se, com especial ênfase, este raciocínio, capaz de surpreender, provavelmente, os seus contemporâneos: o caráter mútuo do prazer obtido por ambos os parceiros do sexo amoroso, o que torna ilegítimo o pagamento por parte de um deles. É que, se o proveito é mútuo, não será razoável que um deles alcance um segundo proveito. $\mathrm{O}$ que mais sobreleva, neste juízo de valor, é esta espécie de igualdade entre homem e mulher, no momento em que desfrutam do prazer físico do amor. A conclusão, logo a seguir, é óbvia: 
Quae Venus ex aequo uentura est grata duobus, altera cur illam uendit et alter emit?

Cur mibi sit damno, tibi sit lucrosa uoluptas quam socio motu femina uirque ferunt?

Se é certo que Vénus há-de dar prazer igual aos dois, porque é que há-de ela vender, e ele há-de comprar?

Porquê me há-de dar prejuízo a mim e a ti há-de dar lucro o prazer que em ritmo emparceirado alcançam a mulher e o homem?

(Amores, 1.10.33-36)

Merecem destaque, pela surpresa que terão causado no seu tempo, expressões emblemáticas destes versos: prazerigual aos dois... ritmo emparceirado.

E prossegue: deve o homem ficar grato à mulher que se entrega de vontade e sem outra retribuição que não seja a de igual entrega de seu parceiro; se, porém, há pagamento de serviços, o contrato está findo e não há lugar a gratidão nem a qualquer espécie de sentimentos.

Mas a poesia ovidiana prima, também, pela ironia; e é a ironia que o leva a abrir uma exceção: quando o parceiro for um homem rico, senhor de muitos pertences, já nada há a reprovar à mulher que dele se aproveita. Colher fartas uvas é legítimo quando em videiras carregadas (1.10.55).

Verdade seja que a conclusão não segue a mesma linha dos princípios expostos nos versos iniciais: o poeta, enfim, mais não tem para dar que versos; essa será a sua paga. Em última análise, rende-se, por assim dizer, ao que antes abominava. Com uma ressalva, apesar de tudo: a da vontade. Em circunstância alguma pode haver obrigação, pois é ela que põe em causa o amor e o prazer que lhe é próprio:

Nec dare, sed pretium posci dedignor et odi; quod nego poscenti, desine uelle, dabo.

E não é dar, mas, sim, reclamar uma paga que eu desprezo e odeio; o que eu recuso a quem mo pede, desiste de o requerer; eu mesmo darei.

(Amores, 1.10.63-64)

Ou seja, a noção ovidiana de amor implica o conceito de parceria ${ }^{6}$. Mas, porque habita aquela cidade concreta, Ovídio é contraditório. Vejamos, por exemplo, a forma como aborda a violência masculina (uma manifestação de poder, como é sabido) na relação entre sexos. $\mathrm{Na}$ Arte de amar, sustenta a teoria

${ }^{6}$ Já em vários outros textos desenvolvi este tema. Veja-se, por exemplo, André 2006b e André 2010. 
de que a violência é legítima como forma de concretizar a sedução e consumar o amor e o desejo (Ars, 1.661-702).

Já nos Amores, porém, em elegia onde evoca o seu próprio comportamento - um episódio de agressão à sua amada -, autoflagela-se, e o canto só tem lugar para o remorso.

A abertura da elegia marca o ritmo, por assim dizer, de todo o poema:

Adde manus in uincla meas (meruere catenas), dum furor omnis abit, siquis amicus ades.

Acorrenta as minhas mãos (bem merecem os grilhões), enquanto toda a fúria se esvai, se, porventura, és meu amigo.

(Amores, 1.7.1-2)

E logo explica o motivo de tão forte impulso no sentido da autoflagelação: a fúria lançou contra a minha dama meus braços desvairados.

Foi, assume, um momento de verdadeiro desvario, que o poderia ter levado, se a ocasião surgisse, a agredir os próprios pais ou, mesmo, a empunhar o azorrague contra os próprios deuses. Assim foi a sua atitude: dilacerou-lhe os cabelos, comportou-se como um louco, como um bárbaro.

A reação dela foi de surpresa, de pavor, de reprovação, de uma tristeza que era, ao mesmo tempo, um libelo acusatório:

Ipsa nibil; pauido est lingua retenta metu;

sed taciti fecere tamen conuicia uultus,

egit me lacrimis ore silente reum.

Ela nada disse; a língua ficou tolhida de um medo pavoroso;

mas o rosto, no entanto, exprimiu a sua reprovação,

e, com as lágrimas a correr na face silenciosa, fez de mim réu.

(Amores, 1.7.20-22)

Teria sido preferível que os braços lhe tombassem, decepados, instrumentos que foram de crime tão hediondo e de inútil manifestação de prepotência. Exibiu forças nascidas do desvario, para seu mal, pois sofre, agora, no remorso, a punição pelo seu gesto, só aparentemente forte e valente. Ainda por cima, agiu ao arrepio dos mais elementares princípios da equidade no direito, ainda que, do ponto de vista formal, a lei o não puna (paradoxo que explicitamente rejeita, ainda que de forma retoricamente hábil):

An, si pulsassem minimum de plebe Quiritem, plecterer; in dominam ius mibi maius erit? 
Se, porventura, tivesse agredido o mais insignificante dos cidadãos, seria punido; e contra a minha amada terei eu mais direitos?

(Amores, 1.7.29-30)

Agrediu quem jurara amar (conceitos que, desta forma, opõe diametralmente, mais uma vez em detrimento da opinião corrente entre os homens do seu tempo); pois bem, proclama ironicamente, pode encenar o seu cortejo triunfal, subir ao carro dos generais vitoriosos, ele que triunfou de uma mulher, seguir atrás dela, que irá à frente, como as cativas, de cabelos desgrenhados e faces magoadas. Melhor seria que o corpo dela exibisse as marcas de seus lábios, ao invés das marcas de seus braços e mãos. Mais fácil teria sido praguejar contra ela, gritar-lhe, ameaçá-la, despi-la, até (o que poderia poupá-la, já que o seu corpo podia servir-lhe de salvo conduto). Mas não; preferiu arrancar-lhe os cabelos, arranhar-lhe a face, deixá-la sem pinga de sangue, até que as lágrimas lhe inundaram o rosto.

Foi aí que o arrependimento o assaltou; foi aí que sentiu arderem-lhe no seu rosto as lágrimas dela; foi aí que o agressor se converteu em suplicante, mas demasiado tarde.

Tunc ego me primum coepi sentire nocentem; sanguis erat lacrimae, quas dabat illa, meus.

Ter tandem ante pedes uolui procumbere supplex;

ter formidatas reppulit illa manus.

Então, comecei eu, primeiro, a sentir-me culpado; eram sangue meu as lágrimas que ela derramava.

Três vezes, por fim, quis lançar-me a seus pés, suplicante; três vezes ela me repeliu as mãos que lhe metiam medo.

(Amores, 1.7.59-62)

Podemos interrogar-nos sobre a sinceridade do poeta. A elegia parece excessivamente retórica, para lhe darmos crédito. Podemos questionar-nos sobre as intenções de Ovídio; o poema soa um tanto, digamos, a encenação. Ao contrário de Leslie Cahoon, no entanto, não creio que estes sejam os termos em que Ovídio pensa o amor e de que, para ele, o sexo é uma expressão de hostilidade e não de amor. ${ }^{7}$ Mais fácil será aderir a uma outra leitura, segundo a qual o poema é perpassado por uma enorme dose de humor, uma vez que a situação que descreve não teria violência alguma, mas, sim, retrataria uma

\footnotetext{
${ }^{7}$ Cahoon 1998298.
} 
simples "birra" entre amantes ${ }^{8}$, humor, nesse caso, a que pode acrescer uma certa dose de ironia9.

Mas podemos, também, ter a visão menos simplista de Ellen Greene. Discorda ela de vários autores que sustentam que a representação da violência sexual corresponde a uma estratégia literária complexa que visa desmascarar e condenar a brutalidade própria, nesse tempo, das relações amorosas; mais do que isso, sublinha esta autora, o que se depreende é uma sugestão de que a exploração da mulher é vista por Ovídio como um paradigma de um sistema social e politicamente corrupto ${ }^{10}$.

A ser assim, estamos, uma vez mais, perante o poeta que age e canta na cidade e que nela entende dever participar com a voz a emergir num território, o amor, onde se sente com especial autoridade.

O facto é que este não deixa de ser um comportamento estranho, se inserido no seu contexto epocal. Na Roma do amor, o parceiro masculino não sofre de remorsos e muito menos tem a menor intenção de se castigar por se ter excedido na consumação do desejo. Na Roma do amor as coisas passam-se exatamente ao contrário. Mas a verdade é que Ovídio nem sempre parece ver a sua cidade através do olhar do parceiro masculino. E, vistas do lado da mulher, as coisas terão de ser, necessariamente, diferentes.

Olhemos, a título de exemplo, uma vez mais, uma das muitas modalidades de doutrinação no amor ou, se se preferir, uma cartilha da amante, nos ensinamentos que uma alcoviteira transmite à sua pupila. Não são ensinamentos do poeta, bem entendido, o qual, aliás, no final do texto, assume claramente a sua indignação face ao que acabara de ouvir (e de escrever); mas serão, sem dúvida, preceitos usuais no seu tempo e ministrados por essas negociantes do sexo; e, como tal, é, também, uma forma de retratar a cidade e, por isso mesmo, de nela intervir.

Lição primeira: a beleza não é bastante para que a mulher triunfe; é necessário acrescentar-lhe a elegância:

Tam felix esses quam formonsissima, uellem.

Que fosses tão afortunada quanto és por demais formosa, eis o que eu queria!

(Amores, 1.8.27)

Lição segunda: a uma e outra será importante acrescentar a riqueza (do que advirá vantagem, claro, para a própria doutrinadora, ou seja, a alcoviteira).

\footnotetext{
${ }^{8}$ Khan 1966 880-894.

${ }^{9}$ Stirrup 1973 824-831.

${ }^{10}$ Greene 1994345.
} 
Lição terceira: o pudor fingido tem as suas vantagens e é de suma utilidade; mas, sublinhe-se, fingido, pois não convém exagerar:

Erubuit. «Decet alba quidem pudor ora, sed iste, si simules, prodest; uerus obesse solet.»

Ela corou. «Fica bem o pudor à candura do rosto, mas apenas se o fingires te será útil; quando autêntico, costuma ser nefasto.»

(Amores, 1.8.35-36)

Lição quarta: cada homem tem o seu preço, cada olhar é uma moeda de troca. O conselho, aliás, é sugestivo, na sua dimensão, quase, de caricatura: o olhar deve baixar ou subir, em função da paga que exibir o homem que diante dela se apresenta:

Quantum quisque ferat, respiciendus erit.

À medida do que te trouxer, assim deves pôr o olhar em cada homem.

(Amores, 1.8.38)

Lição quinta: há que aproveitar o tempo e a juventude, que um e outro se esvaem, quase sem darmos por isso; além de que a roupa não usada degrada-se e perde préstimo e beleza, tal como a casa por habitar sucumbe à invasão do bolor (1.8.49-53).

Lição sexta: cultivar um ou dois amantes, ao invés da exclusividade no amor, apresenta enormes vantagens:

Nec satis effectus unus et alter babent; certior e multis nec iam inuidiosa rapina est;

plena uenit canis de grege praeda lupis.

E não produzem efeito bastante um ou dois amantes:

mais segura é a colheita de entre muitos e menos dada a invejas:

de entre um rebanho, mais farta presa surge ao lobo de pêlo esbranquiçado.

(Amores, 1.8.54-56)

Lição sétima: entre versos e riqueza, a escolha deve recair na segunda. $\mathrm{O}$ poeta mais não pode dar que versos. Mas aquele que trouxer ricos presentes, esse, sim, é grande e merecedor de maiores honrarias do que Homero. A porta da mulher, de resto, dirá mais abaixo (77-78), deve ser surda a quem pede, aberta a quem trouxer presentes. $\mathrm{E}$ amiúde insiste na mesma nota do interesse material, ao longo de toda a elegia.

Lição oitava: a ambição desmedida leva à perdição. Há que reclamar, 
no começo, um preço moderado e acessível; só depois de garantida a presa e alcançada a certeza de que não escapa, poderá a mulher dar largas ao seu capricho:

Parcius exigito pretium, dum retia tendis, ne fugiant; captos legibus ure tuis.

Reclama um preço modesto, enquanto estendes as redes, para te não fugirem; depois de os apanhares, chega-lhes lume, à tua vontade. (Amores, 1.8.69-70)

Lição nona: cultivar o fingimento, levar o parceiro a acreditar que é amado.

Lição décima: fazer-se rogada. A conquista fácil pode ser nefasta à mulher; mais proveitosa será se aparentar ser difícil e quase inacessível. Mas sem resistência em demasia, para que não acabe por dar lugar à desistência, sem remissão:

Saepe nega noctes; capitis modo finge dolorem, et modo, quae causas praebeat, Isis erit.

Mox recipe, ut nullum patiendi colligat usum, neue relentescat saepe repulsus amor.

Nega, muitas vezes, as tuas noites; ora finge uma dor de cabeça, ora há-de ser Ísis a fornecer-te pretextos.

Recebe-o logo depois, para se não acostumar a padecer, e não vir, muitas vezes, a amolecer, por ter sido rejeitado, o amor.

(Amores, 1.8.73-76)

Lição undécima: vantagem existe, também, em fingir-se magoada e, mesmo, enraivecida contra o amante. Uma vez mais, no entanto, sem exageros. Uma raiva de duração excessiva ou exagerada dimensão pode ter efeito contrário ao que se pretende.

Lição duodécima: aprender a chorar, como, de resto, se recomendava em dado momento, na Arte de amar.

Lição décima terceira: suscitar ciúme. $\mathrm{O}$ amor fácil é de pouca dura, ao passo que o amor com risco e difícil tem mais condições para perdurar no tempo:

Ne securus amet nullo riuale, caueto;

non bene, si tolas proelia, durat amor.

Ille uiri uideat toto uestigia lecto

factaque lasciuis liuida colla notis. 
Acautela-te de que nenhum se entregue ao teu amor, confiante de não ter rival; não dura muito, se abolires a contenda, o amor.

Que ele observe vestígios de homem em todo o leito e o pescoço arroxeado por marcas de lascívia.

(Amores, 1.8.95-98)

Lição décima quarta e última: disfarçar o sentimento por detrás de palavras doces, pois o veneno não pode, em circunstância alguma, ser exibido à vista ou deixado a descoberto:

\section{Lingua iuuet mentemque tegat; blandire noceque;} impia sub dulci melle uenena latent.

Que o paleio te ajude a disfarçar o coração; faz-lhe festas e faz-lhe mal; a peçonha do veneno é sob a doçura do mel que melhor se esconde.

(Amores, 1.8.103-104)

Neste caso, pouco importa a posição do poeta, aparentemente discordante em relação aos conselhos da alcoviteira, que o sujeito da enunciação poética escutou, resguardado. Pouco importa, porque o que convém ressaltar, aqui, é que tais preceitos são o retrato de uma prática corrente na Roma do amor. Ao expô-los, assim, a nu, ainda que para deles discordar (se é que a discordância não é mera estratégia), o poeta está a retratar a cidade e, uma vez mais, a nela intervir, ainda que nesse território tão pouco usual na intervenção cívica, como é o território do amor. Porque as lições da alcoviteira conduzem ao retrato, ou antes, a um dos retratos da mulher em Roma ${ }^{11}$.

Um outro retrato, porventura mais complexo ou, talvez melhor, mais ambíguo, é o que vem plasmado na Arte de amar, logo no começo do livro I. Aí, as mulheres que afluem ao teatro, mais para se entregarem ao jogo da sedução do que para ver os jogos, são comparadas às formigas que, pressurosas, carregam a comida que há-de ser armazenada para os dias longos do inverno, ou às abelhas que vão recolhendo, meticulosas, o néctar de que hão-de fazer o mel. Repare-se no texto:

Vt redit itque frequens longum formica per agmen, granifero solitum cum uebit ore cibum, aut ut apes saltusque suos et olentia nactae pascua per flores et thyma summa uolant, sic ruit ad celebres cultissima femina ludos (copia iudicium saepe morata meum est);

${ }^{11}$ Veja-se O'Neill (1999), para uma comparação, talvez um tanto desajustada, entre esta elegia ovidiana e a poesia de Propércio. 
spectatum ueniunt; ueniunt spectentur ut ipsae.

Ille locus casti dampna pudoris habet.

Como vai e vem a multidão das formigas por longo carreiro, quando na boca carregada de grão transporta o alimento costumeiro, ou como as abelhas, quando encontram os bosques que lhes são caros

e os prados cheirosos, voam por sobre as flores e o alto tomilho, assim acorrem as mulheres todas aperaltadas aos jogos cheios de gente (a abundância bastas vezes estorvou a minha escolha); vêm para ver; vêm para elas mesmas serem vistas.

Esse lugar está repleto de riscos para o casto pudor.

(Ars, 1.93-100)

"A simbologia adoptada é curiosa e por demais significativa: são pequenos animais, usualmente tidos por paradigmas de esforço e labor, sempre concentrados na sua ocupação; duas notas, em especial, parecem ressaltar desta comparação - a pequenez, por um lado, e, por outro, o trabalho. Assim, a disponibilidade para a sedução é por Ovídio configurada como uma ocupação tão nobre como a das abelhas e a das formigas quando buscam alimento."12

A imagem que dá da mulher, neste pequeno símile, está longe, portanto, de ser inocente. Num tempo em que a mulher deveria, em princípio, prestar-se à sedução, mas numa atitude passiva (assim o preceitua o próprio poeta), Ovídio, subtilmente, confere-lhe um papel ativo e reconhece-lhe o poder da iniciativa. Ou seja, só aparentemente e por uma questão de tática a mulher se apresta, assim, a ser seduzida; ela está, de facto, a afadigar-se na busca do amor, o mesmo é dizer, a seduzir.

Confirmá-lo-á, de novo, o poeta na abordagem daquilo a que poderíamos chamar o "jogo das cedências", neste caso na doutrinação que tem por destinatário o homem.

O que está em causa é uma espécie de tática da insistência masculina, seja no processo de sedução, seja naquele outro que tem por objetivo conservar os favores da amada. Em ambos os casos, a superioridade e a intransigência são inimigas do sucesso; pelo contrário, o espírito de cedência, nos mais pequenos detalhes, nos pormenores mais insignificantes, pode ser meio caminho andado para o êxito: simular a derrota, render-se aos caprichos da mulher, transigir, eis o rumo mais certo e mais promissor.

Para tanto, o poeta vai ao ponto de recomendar que o homem aceite a humilhação: que se descaraterize, que perca a sua personalidade e a sua autenticidade, que se submeta. Os fins justificam os meios, dirá; se necessário for, que o homem se converta em marioneta. Só tem a ganhar com isso:

\footnotetext{
${ }^{12}$ André 2006a 107.
} 
Cede repugnanti; cedendo uictor abibis; fac modo quas partis illa iubebit agas. Arguet, arguito; quidquid probat illa, probato; quod dicet, dicas; quod negat illa, neges; riserit, adride; si flebit, flere memento.

Imponat leges uultibus illa tuis.

Seu ludet numerosque manu iactabit eburnos, tu male iactato, tu male iacta dato; si iacies talos, uictam ne poena sequatur, damnosi facito stent tibi saepe canes.

Cede quando ela teima; se cederes, sairás vencedor; trata, apenas, de agir como ela determinar.

Se ela contestar, contesta; o que aprovar, aprova-o;

o que afirmar, afirma-o; o que negar, deves negá-lo;

se rir, ri-te; se chorar, lembra-te tu de chorar; seja ela a ditar as leis às tuas feições.

Se, no jogo, lançar de sua mão os dados de marfim, lança-os tu sem jeito; e, depois de os lançares, dá-lhos; se lançares os ossinhos, para ela não ser punida com a derrota, faz com que te saiam muitas vezes os malfadados cães.

(Ars, 2.197-206)

Paradigmático é o verso 202, acabado de citar: seja ela a ditar as leis às tuas feições. É a subversão total do protocolo amoroso vigente em Roma. O que prevalece não é já o poder masculino, é a aparência, o faz-de-conta, a máscara, que se usa ou substitui consoante os interesses de momento e a pressão das circunstâncias.

Mas não se fica por aqui. Segue-se um elencar quase surreal das atenções de que deve o homem rodear a amada: protegê-la das agruras do calor, segurando em sua mão o guarda-sol; seguir à sua frente a abrir caminho, em meio da multidão; e, até, se necessário for, calçá-la, aquecer-lhe as mãos enregeladas, segurar-lhe o espelho (Ars, 2.209-216).

Segurar-lhe o espelho. Esta é uma atitude, de entre as recomendações ovidianas, com uma força simbólica particularmente expressiva e que não deixa de suscitar alguma estranheza. Segurar o espelho, por um lado, é múnus de escravo, uma tarefa servil, pouco ajustada, portanto, a ser desempenhada por cidadãos livres ${ }^{13}$. E representa, por outro lado, a inversão dos papéis: ao proceder assim, aceita o amante a sua própria retirada de cena, para deixar todo o espaço livre à mulher; ao segurar-lhe o espelho, de facto, ele retira-se

${ }^{13}$ Lilja 19655. 
do espaço de contemplação dela, ao passo que ela tem, como contraponto de si, apenas a sua própria imagem, sugestivamente suportada pelas mãos dele; digamos que, assim, o homem se converte, de alguma forma, num alter ego da mulher.

Com esta quase despersonalização de um dos parceiros, a hierarquia do amor, face ao que era uso e tradição em Roma, sofre, aqui, um rude abalo.

Mas a mulher não se dará por satisfeita com tão pequenas vitórias. Deve ir mais longe, impor regras, demorar a rendição, deixar bem claro que não está disponível a cedências sem luta e a ser presa fácil e rápida. É que o amor nascido de favores que com ligeireza se concedem acaba por ser de curta duração. $\mathrm{O}$ amante deve sentir que a empresa é de monta; importa erguer barreiras, dificultar o intento, forçar à provação. A facilidade é avessa ao prazer; é aí, aliás, que tem raízes a fragilidade do amor conjugal, se é que de amor se trata; o desejo é pouco mais que inexistente nos maridos, pois vêem as suas mulheres sempre que lhes apetece (Ars, 3.579-586).

Tal visão, pouco ortodoxa para o seu tempo, insista-se, voltará a confirmála o poeta naquele seu livrinho, tão breve quanto emblemático, que são os Remedia amoris. Só aparentemente é um opúsculo dominado pelo humor, destinado a preparar os amantes (em especial os amantes masculinos) para as agruras do amor. Em boa verdade, o pequeno livro é um prodígio de ironia, cujo sentido mais profundo remete bem para além daquilo que aparenta. Lidos com atenção, os Remedia refletem uma visão do processo amoroso em que o poder está, quase todo ele, do lado da mulher; ela é a perversão em pessoa, ela manipula, ela urde todas as teias, ela define as regras e o ritmo, ela é, ao mesmo tempo, o sujeito, a destinadora e a destinatária, num processo em que ao homem mais não cabe do que ou a derrota ou a fuga. Os Remedia visam, afinal, ensinar o homem a resistir, a fugir, a escapar à força e ao domínio da mulher. O mesmo é dizer que, lidos na sua mais profunda dimensão, os Remedia, à semelhança de tantos outros passos ovidianos, refletem a subversão daquilo a que tem vindo a chamar-se o protocolo amoroso, tal como concebido, aceite e praticado no quotidiano da Roma do seu tempo.

Estes serão, apenas, alguns exemplos, entre muitos outros. Mais longe poderia ir-se. Mas estes ilustram bem a consciência de Ovídio enquanto poeta na cidade, e o espaço de intervenção que escolheu na sua cidade. Não será menor, por certo, do que o espaço de intervenção dos outros, os chamados grandes, ou seja, os que celebram a cidade em tom grandioso e que ficaram, por isso, especialmente assinalados nos anais da literatura e da poesia romanas. Raro um poeta do amor é visto a esta luz, raro se concebe que um poeta de amor participe e intervenha, de modo tão acutilante, na cidade. Mas Ovídio é, sem dúvida, um caso muito especial e disso ele mesmo tinha consciência. 
Atente-se numa outra elegia dos Amores, onde o poeta se defende das acusações de indolência e de poeta menor, indigno da grandiosa tradição poética que deu fama a tantos outros. A verdade é que não é por ter escolhido o género poético que escolheu que se considera menor. Pelo contrário, diz aos seus detratores, invejosos, que o criticam por se não dedicar à eloquência própria do foro:

\section{Mortale est quod quaeris opus; mibi fama perennis} quaeritur, in toto semper ut orbe canar.

É obra mortal essa que reclamas; é uma fama duradoura, a que reclamo eu, para, no mundo inteiro, por todo o sempre, ser celebrado.

(Amores, 1.15.7-8)

E assegura: viverão Homero, Hesíodo, Calímaco, Sófocles, Arato, Menandro, Énio, Varrão, Lucrécio, Virgílio, Tibulo, Galo. Assim também ele não há-de perecer. E, assumindo para si mesmo, sem ambiguidades, a grandeza dos nomes maiores da poesia grega e latina, proclama:

Vilia miretur uulgus; mibi flauus Apollo pocula Castalia plena ministret aqua, sustineamque coma metuentem frigora myrtum atque ita sollicito multus amante legar.

Coisas reles, eis o que o vulgo há-de admirar; a mim, que o loiro Apolo me sirva taças transbordantes de água da Castália;

e possa eu depor em meus cabelos o mirto que receia o frio e seja, assim, lido pelo amante em sobressalto.

(Amores, 1.15.35-38)

E, para que não restem dúvidas, conclui, à maneira de Horácio:

Ergo etiam cum me supremus adederit ignis, uiuam, parque mei multa superstes erit.

Portanto, quando de mim se achegar a derradeira chama, viverei, e uma grande parte de mim há-de sobreviver.

(Amores, 1.15.41-42)

É por isso que se não coíbe de pôr em confronto a sua elegia, o metro e género que escolheu na quase totalidade da sua obra, e a tragédia. Uma e outra se encontram no poema que abre o terceiro e último livro dos Amores. A Elegia, de cabelos perfumados, trajada de elegância, toda ela formosura e 
encanto; a Tragédia, de passo pesado, o rosto sisudo, altiva e de ar afetado.

Verbera esta última o poeta do amor, alvo da chacota de toda a cidade, indolente e preguiçoso, sem brilho, medíocre, fraco de engenho; e desafia-o a abraçar causa mais nobre e estilo mais digno e a escolher a tragédia como rumo de vida.

Não se fica sem resposta por parte da Elegia. Reconhece, com ironia, a grandeza da sua rival, o estilo sublime, o ar pesado, a nobreza, em contraste com a sua própria humildade e brejeirice. Mas logo, não obstante, apregoa os seus feitos: abre as portas do amor, ensina as técnicas do prazer, ilude a vigilância de maridos severos e de escravos ao seu serviço, aguça o engenho dos amantes.

Busca o poeta, em meio da contenda, a concórdia entre ambas; à Tragédia manifesta respeito, à Elegia revela apego. E é por esta a opção final, fiel aos brandos amores que nela se plasmam. Também aqui Ovídio é o poeta na cidade, mas, sobretudo, o poeta da sua cidade.

E, na cidade, poeta de todos. A poesia ovidiana não contém exclusões, não marginaliza. É o poeta dos festins e dos grandes salões, mas também o poeta dos pobres, que o amor possui uma dimensão universal. Ele mesmo, seja por conveniência, seja por estratégia retórica, se inclui nesse número:

Pauperibus uates ego sum, quia pauper amaui. Cum dare non possem munera, uerba dabam.

Pauper amet caute, timeat maledicere pauper multaque diuitibus non patienda ferat.

Eu sou o poeta dos pobres, pois foi pobre que amei; já que não podia ofertar presentes, oferecia palavras; que o pobre ame com recato, que receie ser maldizente o pobre e suporte muitas coisas que não seriam capazes de tolerar os ricos. (Ars, 2.165-168)

Como acima se diz, estes serão, apenas, alguns exemplos colhidos no vasto painel que é a poesia de amor ovidiana, onde perpassa a cidade, as suas gentes, os seus hábitos, os seus segredos, os seus recantos mais escusos, os seus salões deslumbrantes.

Olhemos, tão-só, em jeito de balanço de conjunto, a partição dessa mesma obra, toda ela cantada na cidade do amor:

O manual da ciência amorosa, desde logo. Nas entrelinhas dos preceitos sabiamente urdidos, nos passos só aparentemente desconexos da doutrinação, é a cidade que fervilha, que pulsa, que vemos em movimento. As técnicas da sedução e as técnicas da traição, as artes da conquista e as artes do engano, os segredos do encanto e os segredos do prazer, a força do amor e a força da 
vertigem, tudo isso é Roma, na sua essência de centro cosmopolita e, talvez por isso mesmo, de centro onde o amor polariza o cenário urbano.

O canto do amor nas suas múltiplas facetas, assumido na primeira pessoa, é verdade, mas com uma mal disfarçada dimensão coletiva. O amor-engano, sempre e uma vez mais; o amor-volúpia, que Ovídio não conhece outro amor, a não ser aquele que em prazer se corporiza; o amor-sensualidade, parceiro sem emenda desse Eros que com ele fez a viagem da história e a viagem do homem na história; o amor-serviço ou amor-prisão, também, apesar de Ovídio não ser muito afeiçoado a esses caminhos mais trilhados por outros, como Propércio ou Catulo.

A prevenção contra os malefícios do amor, nesse prodígio de ironia (quase a raiar o cinismo), que são os Remedia amoris. O reconhecimento do poder da mulher no amor e da consequente necessidade de o homem se precaver em relação a ela, de forjar armas, não já para a conquistar, como ensinava na Arte de amar, mas para contra ela combater.

E, até, um tratado de cosmética feminina, os Medicamina faciei femineae, que também de estética rebuscada se faz o amor em Roma, na arte com que a mulher se entrega ao seu jogo, quer consideremos que, passivamente, se apresta a ser seduzida, quer, como mais seguramente parece, entendamos que se apronta a seduzir.

Vale a pena, em especial, considerar as duas últimas obras referidas: aquela que ensina a mulher a materializar alguns dos truques básicos da sedução, ou seja, a cosmética, e aquela onde adverte os homens contra o poder quase insuspeitado dessa mesma mulher. Uma e outra refletem bem a Roma onde Ovídio viveu, até ao momento em que o Imperador o desterrou, por motivos que a história nunca nos dirá, mas que a lenda sempre há-de afiançar terem a ver com este retrato frio de uma cidade que vivia para o amor.

Faltaria, em todo o quadro, uma dimensão mítica. Ela é conseguida, por um lado, com as Metamorfoses e, por outro, com as Heroides. Mas essa é viagem que não cabe nos limites estreitos deste pequeno esboço.

Ovídio, poeta do amor, é bem o poeta na cidade e o poeta da cidade. A mesma de onde seria banido para um exílio sem remissão, ainda no fulgor do seu canto e no fulgor da sua arte de retratista urbano. Com outros olhos passará, a partir de então, a olhá-la.

Essa será, porém, outra visão deste poeta. Não já o poeta na cidade, decerto, mas o poeta fora dela (ou talvez não). Sempre, em todo o caso, o poeta da cidade. 


\title{
A Roma dos Flávios: GENTE E SENTIMENTOS NOS EPIGRAMas DE MARCIAL
}

\author{
Maria Cristina de Castro-Maia de Sousa Pimentel \\ Universidade de Lisboa \\ Centro de Estudos Clássicos
}

Bajulador e obsceno: dois rótulos que, ao longo dos tempos, se colaram ao poeta Marco Valério Marcial e prejudicaram a avaliação dos seus leitores, guiados por estudos que, sucessiva e acriticamente, seguiam perspectivas herdadas de outros, e, também, por preconceitos datados e princípios morais mais inflexíveis, ainda que, quantas vezes, não inteiramente sinceros. Estamos hoje, para o bem e para o mal, libertos de constrangimentos que afectem a nossa leitura dos autores antigos, e podemos por isso olhar para Marcial com olhos mais lúcidos, sem confundir valor literário com valores morais. Isso nos leva a questionar, perante os quinze livros de epigramas, a perspectiva do poeta no tocante ao poder instituído, bem como ao papel do sexo na sociedade romana em que vivia e, é claro, na sua própria vida.

Relativamente à adulação,julgo pertinente lançarmos as seguintes questões: Marcial adulou porque quis adular, uma vez que admirava o princeps e a época em que vivia? Ou tê-lo-á feito porque lhe era necessária e conveniente essa atitude para alcançar a fama e, em última instância, sobreviver? Adiantando uma resposta, e sem prejuízo do debate que estas perguntas possam suscitar, direi que, quanto mais leio os Epigramas e estudo a época dos Flávios e o dealbar da dos Antoninos, mais me parece que a poesia de Marcial deixa transparecer a simbiose entre dois sentimentos: a admiração pela obra feita pelos principes e pela expressão do seu poder, e o desejo, afinal bem compreensível, de assegurar a sua própria fama e garantir o pão de cada dia.

Marcial chegou a Roma pelo ano 64 do séc. I da nossa era. Vinha de Bílbilis, a cidade pequenina onde nascera, na Hispânia Tarraconense, lugarejo que decerto the pareceu acanhado para os seus sonhos e para o caminho da fama que o seu talento almejava. De outro modo, porque teria partido? Quando chegou à capital do império, de imediato se deve ter deslumbrado com a grandeza dos monumentos: que impressão the terá realmente causado a Domus Aurea e o colosso de Nero, cujo espavento se verá mais tarde na obrigação de exprobrar ( $S p$. 2), morto o megalómano que os concebera? Bem depressa o poeta se deve ter deixado impressionar pela agitação e o requinte das festas e dos jogos, pelo luxo dos ricos e a autoridade dos poderosos. Tudo era tão diferente da terrinha de onde saíra e onde um dia, muitos anos depois, desencantado, amargo e gasto pelos anos e pela vida estreita, há-de querer voltar, regresso que só serviu para revelar, nas gentes de Bílbilis, o espírito 
tacanho dos invejosos e dos que respiram raiva contra quem ousa rasgar o horizonte ${ }^{1}$.

Em Roma, porém, o poeta experimentou as dificuldades de quem não tem posses nem influência: descoberta a conjura contra Nero no ano 65, e caídos em desgraça os patronos que o haviam acolhido ${ }^{2}$, restou a Marcial procurar quem lhe garantisse o sustento. Não, não regressou à terra natal: como o faria sem se confessar vencido, tão pouco tempo após a partida? Ficou, pois, em Roma, e foi deitando mão ao que podia. E o que podia era pouco mais do que a vida de cliens, via-sacra que aprende a percorrer, ainda quando as manhãs chuvosas, e o sono abreviado, e a humilhação das esperas e dos pedidos, no álgido limiar das casas de patronos arrogantes e ingratos que tão bem retratou nos epigramas ${ }^{3}$, lhe deixavam o amargo de boca de quem não é, e sente que não é, livre ${ }^{4}$. Longos anos de deserto, os que atravessou, aqueles em que nada sabemos do que terá feito: mas podemos imaginar que, a par da rede de amici que foi tecendo, uns mais chegados, outros mais tiranos e egoístas, lá foi o nosso poeta observando, quase sempre mordaz, mas algumas vezes também tocado de compaixão ou movido de simpatia, os inúmeros traços da comédia e a mão-cheia de chagas da tragédia da vida em Roma e dos seus protagonistas, instantâneos que guardava na memória e de que depois fazia a seiva dos seus epigramas.

Com a chegada de Tito ao poder, Marcial encontra a oportunidade de, enfim, colher da sua arte algum fruto mais sumarento do que as migalhas da mesa daqueles que lhe garantiam a espórtula diária e a decência de uma

${ }^{1}$... a má-lingua dos munícipes e a inveja, em lugar da crítica, e um ou dois malévolos, demasiados para lugar tão pequeno é o que Marcial encontra no seu regresso à terra natal, como diz na epístola introdutória do Livro 12, dirigida a Terêncio Prisco. Na citação dos passos traduzidos, usamos a edição dos Epigramas de Marcial, com introdução e notas de Cristina Pimentel, e tradução de Delfim Ferreira Leão (Livros Dos Espectáculos, 4, 7, 11 e 13), José Luís Brandão (Livros 1, 2, 6, 9 e 12) e Paulo Sérgio Ferreira (Livros 3, 5, 8, 10 e 14), Lisboa, 4 vol., 2000-2004.

${ }^{2}$ Concretamente os Sénecas e os Pisões, que evoca com saudosa gratidão em 4.40,1-2. Cf. 12.36.8.

${ }^{3}$ São recorrentes, nos epigramas, as referências aos atria e aos limina dos poderosos, i.e., dos patronos que não eram amici, o que se vê nas sinédoques que designam a casa: os clientes não passavam do limiar ou, na melhor das hipóteses, do atrium, jamais tinham acesso ao coração da domus, reservado para íntimos e próximos. V. v.g., 1.70 .13 (limen superbum); 5.20 .5 (atria potentum); 12.18 .4 (limina potentiorum); 12.68 .2 (atria ambitiosa), além de 1.55.5-6; 9.100; $10.10 ; 70 ; 74 ; 11.29(26) ; 12.29 .$. Outra situação amiúde denunciada no comportamento dos patronos é a das cenae em que aos clientes eram servidos alimentos e bebidas diferentes (e, obviamente, de muito pior qualidade) dos que os que o patrono consumia. V., e.g. 1.20; 3.60; 4.68; 6.11; 10.49... Não admira, pois, o desabafo de 5.22.13: Semper inbumanos habet officiosus amicos (Sempre desumanos tem o cliente os seus amigos!).

${ }^{4} \mathrm{~A}$ um cliens como ele, que vive e se alimenta à custa de patronos, mas pensa que tem o direito de falar mal deles e insultá-los, assegura o poeta, lapidarmente: Liber non potes et gulosus esse (9.9.4: livre e guloso ao mesmo tempo é que não podes ser). Cf. tb. 2.53. 
toga. Pese embora alguma crítica que relacionou o Liber Spectaculorum com a celebração de jogos em tempo de Domiciano, cremos que foi em 80, para os fabulosos ludi de inauguração do Anfiteatro dos Flávios, depois conhecido por Coliseu, como celebração desses cem dias em que todo o mundo romano, numa variedade de raças e povos $(S p .3 ; 27.1)$, se concentrou na capital para ver o espectáculo com que o imperador ostentava o seu poder, que Marcial compôs, e divulgou junto de quem importava que o conhecesse, o livrinho que nos revela alguém que, no meio da multidão, se fascina com o aparato, com a grandiosidade dos diferentes momentos do espectáculo: os homens e os animais na arena, até as mulheres a enfrentarem as feras em inusitada uenatio, os ballets aquáticos, a naumaquia, as fabulae mythologicae com as suas fantásticas maquinarias - e a crueza do seu final -, os pares de gladiadores ou os bestiarii de excepção, a chuva de açafrão caindo sobre os espectadores, e, lá em cima na tribuna imperial, o princeps, a quem todos, homens e animais, prestavam a homenagem que lhe era devida ${ }^{5}$. Até que ponto Marcial se deixa guiar pela genuína admiração pelo senhor de Roma, nunca o saberemos. Mas, no tom com que o sentimos vibrar perante o que os seus olhos vêem, podemos descortinar, pelo menos, a sinceridade de quem admira o que Roma dá ao mundo, e o orgulho de quem se sente parte integrante de um povo que considera superior a todos os outros. Por muito que hoje em dia, lembrados de ideologias que exterminaram milhões de seres humanos considerados inferiores, recordados, a cada noticiário, de que esses não são tempos irrevogavelmente esquecidos, por muito que hoje em dia, repito, tal orgulho nos pareça malsão e de consequências sinistras, encarar essa atitude à luz dos nossos valores é interpretação abusiva da parte de quem se debruça sobre o pensar e o sentir de um Romano, e um Romano das últimas décadas do séc. I, quando o império estava prestes a atingir a sua maior extensão, ainda que, sem que delas se desse conta, as sementes do declínio tivessem já começado a germinar.

Recompensado por Tito, confirmado por Domiciano na benesse que o guindava a estatuto social mais elevado, detentor do ius trium liberorum mas não dos três filhos... - tribuno e eques ${ }^{6}$, sem todavia ter conquistado o que nunca tivera nem viria a ter, a efectiva independência económica, como podemos admirar-nos de que Marcial tenha continuado a trilhar, cada vez com mais empenho, os estafados atalhos da adulação? Como podemos estranhar

${ }^{5}$ V. uenationes $(S p .11 ; 12 ; 13 ; 14 ; 15 ; 16 ; 19 ; 21 ; 22)$ e mulheres na arena $(S p .7$ e 8 ; cf. Díon 66.25); ballets aquáticos (Sp. 30; 34); naumaquias (Sp. 27; 34); fabulae mythologicae, mimos, hidromimos e pantomimas $(S p .6 ; 9 ; 10 ; 24 ; 25 ; 28 ; 29)$; pares de gladiadores $(S p .23 ; 31)$ ou bestiarii excepcionais (como Carpóforo: $S p$. 17; 26; 32); as sparsiones, chuva de açafrão lançada sobre os espectadores, com propriedades fumigatórias e odoríferas (Sp. 3.8); a proskynesis de animais (Sp. 20;33).

${ }^{6}$ Cf. $2.91 ; 92 ; 3.95 .5-6 ; 5.13 .2 ; 9.97 .5-6$. 
que ele tenha acreditado que o seu talento haveria de merecer a devida glória entre os Romanos e, em especial, de conquistar-lhe um lugar de preferência junto daquele que detinha nas mãos o poder absoluto, de vida e de morte, sobre tudo e sobre todos?

Aceitemos, pois, esta evidência: Marcial, efectivamente, adula, e a sua ars molda o seu ingenium de modo a desenvolver uma fantástica - ainda que quase nunca bem-sucedida - estratégia de adulação. Marcial concentra-se e emprega todos os recursos que o epigrama the permite, ou que ele próprio lhe confere, para conseguir um objectivo: o encómio de um momento - aquele em que vivia e escrevia - e o de quem, nesse momento, mandava em Roma. Deixemos de parte qualquer juízo de valor sobre os quinze anos do principado de Domiciano, aqueles durante os quais Marcial escreveu e publicou a maioria dos seus livros, tanto mais que, como é óbvio, não é fácil traçar a bissectriz entre a visão laudatória que nos deram autores como, além de Marcial, Estácio, Sílio Itálico, até Quintiliano, e a perspectiva de condenação, tão parcial quanto o encómio, adoptada por escritores como Tácito, Plínio, Juvenal, Suetónio ou também Epicteto, Filóstrato, Díon Cássio: todos, afinal, escritores que o foram quando já podiam escrever em segurança, após a morte de Domiciano, e quando, para engrandecer os novos senhores de Roma, Nerva, Trajano, Adriano, havia que pintar com as mais negras cores a tirania a que eles haviam posto fim, como de resto as normas retóricas do encómio propunham e ensinavam. Marcial, que também tentou fazer o mesmo, procurando, de forma que a nós nos parece quase patética, retractar-se dos louvores cada vez mais desbragados que tecera a Domiciano, pouco ou nada conseguiu. Ao contrário do que sonhara e do que julgara possível, ele nunca deixou de pertencer àquelas franjas da sociedade que não têm peso nem influência. Talvez por isso nos dê a sensação de que ninguém parece ter-se preocupado com ele quando chegou o momento do ajuste de contas. Nada lhe aconteceu de grave, mas também nada lhe aconteceu de bom. Continuou a sua apagada vidinha de cliens, agravada pelo peso dos anos e talvez por alguma má consciência pela volta-face que foi obrigado a fazer, e sempre, sempre sem muito dinheiro nem a duradoura fama que ambicionava. Talvez por isso, também, não possamos deixar de sentir a sinceridade do seu cansaço, do seu desalento, da entranhada velhice que, mais do que o corpo, lhe tolhia o espírito, quando resolve voltar à terra natal, onde, para que o ciclo se feche, nada encontra do que esperava, a não ser as horas em que pode dormir até a manhã ser alta ${ }^{7}$, e onde, ao invés, encontra tudo aquilo

${ }^{7} \mathrm{O}$ desejo de dormir sem entraves e incómodos parece atravessar os Epigramas: v. 1.49.36; 10.74.12; 12.57.28. Num epigrama (12.18) dirigido a Juvenal, que ficou preso em Roma à vida de cliens enquanto Marcial usufrui do sossego de Bílbilis, gaba-se o poeta de ter conquistado o gozo de um sono descaradamente longo / que, amiúde, nem a terceira hora quebra (vv. 13-14: Ingenti fruor inproboque somno, / Quem nec tertia saepe rumpit hora). Por isso, em 12.68, assegura que 
de que fugira aos vinte e poucos anos: a estreiteza das mentes e as dentadas da inveja. $\mathrm{E}$ aí, nesse poço fundo que lhe antecedeu a morte, sentimos também que o seu amor por Roma era genuíno, traduzido nas saudades dos amigos e da vida que lá levava, na falta dos teatros, dos pórticos, dos recintos dos jogos, das bibliotecas, das conversas com gente que, como ele, tinha o espírito fino e apurado para as $\operatorname{artes}^{8}$ e também, porque não?, para a universalmente humana actividade do mexerico e da má-língua.

E então, numa visão que é retrospectiva relativamente à leitura cronológica dos livros dos Epigramas, percebemos que a adulação não foi assim tão desprovida de alguma sinceridade por parte do poeta, quando louvava as qualidades do princeps, as suas vitórias militares - as que obteve de facto e as que a propaganda lhe terá atribuído - as medidas e as leis promulgadas, a política de construções e de jogos que empreendeu, enfim, numa palavra, entendemos o móbil do poeta quando criteriosamente escolhe os acontecimentos e circunstâncias que considerou importante enaltecer (ou denegrir), em campos tão diversos como o social, o militar, o político e religioso, o administrativo, como também compreendemos o seu silêncio sobre outras circunstâncias que, menos douradas, menos transparentes, não cabiam na moldura encomiástica que Marcial, livro a livro, numa vertigem para nós obsidiante e às vezes difícil de aceitar, vai estreitando e apurando até ao limite que as palavras permitem.

No entanto, insistimos neste aspecto, que admiração há em que Marcial, que, mal chegara da Hispânia, viu a destruição causada pelo enorme incêndio que devastou Roma em 64, que viu a cidade arrasada pela guerra civil do ano 69, assolada pelos soldados de Vitélio que a ocupavam e pelos de Vespasiano que a tomaram de assalto, que a viu de novo destroçada por um grave incêndio durante o principado de Tito, que admiração há, pois, que ele se tenha deixado empolgar pela reconstrução que Domiciano levou a cabo, reerguendo o que há décadas jazia em ruínas (5.7), construindo novos e mais esplendorosos monumentos civis e religiosos, enchendo as colinas com estátuas suas, apenas de metais preciosos, e de arcos magníficos em celebração das suas vitórias? Que nos espanta que ele, apreciador como era de andar pelas ruas decerto

foram os officia matutinos que, na sua condição de cliens, tinha de cumprir, que o levaram a deixar a capital e a refugiar-se na terra natal, advertindo por fim: Agrada-me o sossego e o sono que a grandeza de Roma / me negava então: regresso, se nem aqui posso dormir (vv. 5-6).

${ }^{8}$ Mergulhado na pasmaceira provinciana (in ... prouinciali solitudine), Marcial confessa, na epístola introdutória do livro 12, que sente falta dos ouvidos da cidade, da argúcia dos juizos, da fecundidade dos argumentos, pois não tem as bibliotecas, os teatros, as reuniöes, onde se estuda sem que o prazer se ressinta.

${ }^{9}$ Cf. 1.70.5-6; Suet. Dom. 13.6-7; Plin. Pan. 53.3; Díon 67.8.1; 68.1.1. São inúmeros os epigramas em que o poeta exalta a actuação política de Domiciano, traduzida no engrandecimento da cidade e numa época que ele diz entre todas magnífica, pelo respeito das leis, da moral, da tradição, dos ritos e cultos. A título de exemplo, v. 5.19.1-6; 6.4; 8.36;39; 65; 9.3; 5; 101; $10.28 \ldots$ 
em amena cavaqueira com os amigos, de olho alerta a descortinar os podres e os vícios do seu semelhante, tenha achado justíssima a determinação de Domiciano de limpar das ruas de Roma de toda a parafernália dos comerciantes que atravancavam os passeios e atrapalhavam o trânsito com a exposição da traquitana da sua mercadoria (7.61), e se tenha encantado com o embelezamento de casas, janelas, templos e estátuas com rosas que o princeps mandava vir expressamente de estufas que as produziam, mesmo no Inverno $(6.80 ; 13.127)$ ?

Ainda assim, porém, e correndo o risco de fazermos o que tanto queremos evitar, não podemos deixar de reparar que muitas das medidas a que Marcial dá o seu aval são absolutamente reveladoras da sua visão conservadora da sociedade e do governo do estado. Tal é manifesto quando louva todas as medidas que Domiciano promulgou ou reinstituiu reabilitando o mos antiquus, como dizia ser timbre da sua orientação política. Esse desiderato abrangeu campos como a moralização dos costumes ou a restauração do tradicional ordenamento da sociedade, com o necessário respeito pela hierarquia dos estratos que a compunham. Para só referirmos alguns casos, lembremos como, com o pano de fundo dos reiterados encómios à Pudicitia que regressara a Roma pela mão do terceiro Flávio, Marcial rejubila com a reposição em vigor da lex Iulia de adulteriis coercendis - até porque os infractores se punham a jeito da sua mordacidade epigramática! ${ }^{10}$ - ou com a reinstituição da lex Roscia theatralis, que, nos recintos dos jogos, reservava à classe equestre as primeiras catorze filas imediatamente a seguir aos lugares adstritos aos senadores ${ }^{11}$ - e aqui, como se imagina, o eques Marcial era parte interessada na garantia de um lugarzinho jeitoso quando ia aos espectáculos de que tanto gostava. Nessa mesma ordem de ideias, quando o poeta se sente beneficiado por certas medidas e, por isso, não pode senão apoiá-las, ainda que tal não possa estar isento da parcialidade de quem é juiz em causa própria, não podemos estranhar que Marcial não tenha ficado indiferente à variedade acrescida - e talvez também à possibilidade de um maior volume de apostas - que trazia ao espectáculo a introdução de duas novas factiones, a aurata e a purpurea, que vieram juntar-se às quatro já existentes nas corridas do circo $^{12}$. No tocante à parcialidade de Marcial, não podemos deixar de reparar que há

${ }^{10}$ Cf. $2.61 ; 83 ; 5.75 ; 6.2 .1 ; 7 ; 22 ; 45 ; 91 ; 9.5 .8$;

${ }^{11}$ Cf. $3.95 .9-10 ; 4.67 ; 5.8 ; 14 ; 23 ; 25 ; 27 ; 35 ; 38 ; 41 ; 6.9$. V. Suet. Dom. 8.4.

12 14.55; 131; cf. Suet. Dom. 7.1; Díon 67.4.4. As factiones que já existiam eram a ueneta (azul), a prasina (verde), a alba (branca) e a russata (encarnada). As duas primeiras eram as que granjeavam mais adeptos. Os imperadores, consoante queriam parecer mais populares ou mais aristocratas, divulgavam o seu apoio, respectivamente, à factio prasina ou à ueneta. Domiciano 'torcia' pelos Verdes, pelo que, durante o seu principado, segundo o próprio Marcial deixa transparecer, os Azuis não tinham grandes hipóteses de vitória $(6.46 ; 11.33)$. O sucesso das novas factiones não durou mais que o tempo de vida do seu criador. 
uma única medida de Domiciano que ele não apoia, e contra a qual desenvolve aquilo que hoje chamaríamos uma vasta campanha de contestação: trata-se da transformação da sportula devida pelos patronos aos seus clientes que, por imposição imperial, passara de entrega de dinheiro à obrigação de uma recta cena. Mas aí, é claro, Marcial é mais uma vez parte interessada e tem com ele, no coro de protestos, os dois lados da relação clientelar: nem os patronos querem dar uma cena diária à multidão de clientes que lhes servem antes para as campanhas políticas e para a ostentação pública do poder que detêm, nem os clientes estão interessados, porque lhes é materialmente impossível, em sobreviver, a troco de tanta canseira dos officia a que estão obrigados, com a única refeição diária que assim teriam garantida, com a agravante de, como era frequente, ser composta por comida e bebida de segunda ou terceira escolha. Naturalmente, quando a determinação foi revogada, o poeta não pôde senão rejubilar ${ }^{13}$, pois voltava a poder receber, de cada um dos seus patronos, cem quadrantes, o que lhe ia dando para os gastos.

Para a adulação de outras personagens dos epigramas, talvez já seja mais difícil descortinar outros motivos além daqueles que presidem ao desejo de conseguir acesso às mais altas instâncias imperiais, ou, pelo menos, de garantir a ajuda daqueles que gravitavam em torno do centro do poder, que o mesmo é dizer do imperador. Nos seus louvores, Marcial procede segundo um esquema de círculos que, em termos de poder e influência, progressivamente se afastam de um centro, obviamente ocupado pelos principes sob quem escreveu, Tito, Domiciano, Nerva e Trajano, alvos preferenciais da sua poesia, incluindo nessa galáxia de astros também os membros da familia imperial já desaparecidos, em culto rendido a quem fora transformado em diuus ${ }^{14}$.

Em seguida, não enjeita o poeta, numa espécie de segunda linha estratégica, a vantagem de adular ou evocar aqueles que, seguindo carreiras políticas ou militares de relevo, eram responsáveis pela concretização dos desígnios imperiais, ou aqueles que, pela fortuna ou estatuto de que gozavam, pertenciam aos estratos político-sociais dominantes. Para só referirmos alguns exemplos eloquentes, nos Epigramas há espaço para altos funcionários imperiais como Sílio Itálico, Plínio-o-Moço, Cláudio Etrusco e seu pai, a rationibus de Tibério e dos imperadores que lhe sucederam, Licínio Sura, Antístio Rústico, Domício Apolinar, M. António Primo, Mécio Célere, legado na Hispânia Citerior, Istâncio Rufo, que veio a ser procônsul da Bética, o rico e erudito magistrado Arrúncio Estela ${ }^{15}$. A estes nomes juntam-se outros, ligados ao campo da arte,

${ }^{13}$ Cf. 3.7; 14; 30; 60.

${ }^{14}$ Concretamente, a sobrinha, Júlia $(6.3 ; 13 ; 9.1)$, filha de Tito, que se disse ter sido sua amante e ter morrido na sequência de um aborto que Domiciano a obrigou a fazer, e o filho que, em 73, teve de sua mulher, Domícia Longina, morto de tenra idade (4.3; 9.86).

${ }^{15}$ Sem exaustividade, registem-se: Sílio Itálico - 4.14; 6.64; 7.63; 8.66; 9.86; 11.48; 50(49); 
como Rabírio $(7.56 ; 10.71)$, o arquitecto que desenhou e construiu a fabulosa Domus Flauia no Palatino, ou da literatura, como Quintiliano, preceptor dos filhos adoptivos de Domiciano (2.90), ou Colino (4.54) e Caro (9.23; 24), premiados, respectivamente, nos ludi Capitolini e nos ludi Albani, jogos instituídos por Domiciano. Enfim, uma panóplia de nomes dos que hoje diríamos 'colunáveis'.

Quanto aos libertos, afinal também membros da familia imperial, Marcial escolhe aqueles que, dentro do Palatium, tinham funções relacionadas com o tratamento e atendimento do princeps, pois, naturalmente, vê-os como fulcrais no processo de adulação que empreende: a convivência diária com o imperador e a intimidade que daí advinha fazem deles - pelo menos assim o julga Marcial - os intermediários ideais para que o poeta ascenda ao favor do princeps. Para que seja evidente a dimensão deste 'círculo' de personagens que Marcial tenta - quase sempre sem sucesso - ganhar para a sua causa, lembremos brevemente quem eles eram: Parténio, o cubicularius de Domiciano, que acabou por integrar o grupo que planeou e executou o assassínio do imperador; Eufemo, liberto de origem grega que desempenhava funções também de mordomo (tricliniarcha) de Domiciano; Sigero, outro dos seus ministri, que também veio a contar-se entre os amici e liberti imperiais que planearam e executaram o homicídio de Domiciano; Sexto, liberto do princeps, seu secretário e bibliotecário; Entelo, seu a libellis, ao que parece também um dos seus futuros assassinos ${ }^{16}$; Flávio Eárino, escanção de Domiciano e seu puer delicatus, preferido entre todos, a quem Marcial dedica nada menos que um ciclo de seis epigramas $(9.11 ; 12 ; 13 ; 16 ; 17 ; 36)$, decerto no momento em que o jovem atingia o auge do favor do princeps.

O poeta não hesita mesmo perante o louvor de outro grupo de colaboradores próximos de Domiciano, constituído pelos delatores. O exemplo mais expressivo é o de Marco Aquílio Régulo, de quem Marcial nos deixou um retrato elogioso que em tudo contrasta com aquele que outras fontes, como Plínio e Tácito, traçaram ${ }^{17}$. E também não desperdiça a ocasião de adular Crispino, protegido e amigo de Domiciano, aquele sobre quem Juvenal dizia que difficile est saturam non scriber ${ }^{18}$.

Poderíamos acrescentar a estes nomes o de muitos outros que, por esta ou aquela razão, se encontravam próximos do poder, e, sobretudo por isso,

Plínio-o-Moço - 10.20(19); Cláudio Etrusco e seu pai - 6.42; 7.40; Licínio Sura - 6.54.9; 7.47; Antístio Rústico (e a mulher, Nigrina) - 4.75; 9.30; Domício Apolinar - 4.86; 7.26; 89; 10.30; 11.15; M. António Primo - 10.23; 32; Mécio Célere - 7.52; Istâncio Rufo - 7.68; 8.50; 73; 12.95.4; 98.5. Arrúncio Estela, mais amigo que patrono, pelo que lemos nos epigramas, é presença constante na obra de Marcial.

${ }^{16}$ Cf. 4.45; 5.6; 8.28; 9.49;11.1; 12.11 (Parténio); 4.8 (Eufemo); 4.78 (Sigero); 5.5 (Sexto); 8.68 (Entelo).

${ }^{17} 1.12 ; 82 ; 111 ; 2.74 ; 93 ; 5.10 ; 21 ; 28.6 ; 63 ; 6.38 ; 64.11 \ldots$

18 1.30. Em Marcial, v. 7.99; 8.48. 
mereceram a atenção e a reverência de Marcial, que os considerava como que um trampolim para conseguir também ele a desejada intimidade e reconhecimento do imperador.

Também no que toca às mulheres e a uma sua eventual emancipação social e sobretudo sexual podemos descortinar a atitude conservadora do poeta, desconfiado e temeroso do poder de que, em sua opinião, elas davam mostras e de um propósito que as nortearia, a de tomarem nas mãos, até ao limite do possível e muitas vezes infringindo as leis, as rédeas da sua vida, escolhendo quem queriam e como queriam, rejeitando quem não queriam, dominando quando e onde encontravam terreno mole, numa ameaça constante da hierarquia tradicional entre os sexos, numa inversão da ordem que o assustava tanto quanto a ascensão social dos libertos e da gentinha sem escrúpulos. Assim sendo, Marcial enquadra-se, em contraste formal mas com identidade de intenções, no coro de moralistas indignados que a literatura latina nos faz ouvir, irritados com o evoluir dos costumes e dos modos de estar na vida. Marcial ataca, condena, denuncia os excessos, aponta o dedo ao desconcerto do mundo, acumulando exemplos que me dispenso de evocar, num extenso e compósito mosaico que resulta numa tela assustadora de relações humanas pautadas quase exclusivamente pelo fogo da lubricidade e pela febre de arrecadar dinheiro. Nesse sentido, o que faz de Marcial um moralista, ou, talvez melhor, um ressabiado com as mulheres que assumem um comportamento até há pouco considerado eminentemente masculino, dispondo do seu dinheiro e, por isso, mandando, usando os homens como mercadoria de prazer e deles se desfazendo como objectos descartáveis para logo passar a outros amores ou para esbulhar outras bolsas, nesse sentido, dizíamos, Marcial aproximar-se-ia, pelo menos nos objectivos, embora não nos pressupostos, da reflexão de um Séneca que, nas alusões às mulheres, tantas vezes censura a imoralidade, o luxo desenfreado, a abjecção dos comportamentos, como quando refere as fabulosas fortunas que pendiam das orelhas de algumas damas mais abastadas, em brincos de grandes e pesadas pérolas que chamavam a atenção de todos (e lhes deformavam as orelhas.... $)^{19}$, quando, em generalização hiperbólica, se indigna com as vestes caríssimas de seda transparente que revelavam as formas e a desvergonha femininas ${ }^{20}$, quando se agasta com o facto de as mulheres, por terem seguido os maus exemplos dos homens ao quererem tornar-se iguais a eles, estarem a sofrer de gota pelos desmandos alimentares ou de alopecia por excessos da moda e de $\operatorname{cosméticos}^{21}$, ou invectiva as mulheres que já nem

\footnotetext{
${ }^{19}$ Cf. Ben. 7.9.4; Const. 14.1. V. outras referências censórias em Ep. 51.12 (as "mundanas" que passeiam de barquinho na estância termal - e de perdição - em Baias).

${ }^{20}$ Cf. Helv. 16.4; Ben. 1.9.3; 7. 9.5; Ep. 90.20. Também no De Matrimonio Séneca elevou a voz contra as vestes de seda e as jóias, sinais de vida menos digna.

${ }^{21}$ Ep. 95.20-21.
} 
sabiam quantos maridos tinham tido e que, em vez de contarem os anos de vida pela nomeação dos cônsules, os contabilizavam pelos divórcios e sucessivos casamentos $^{22}$. Para qualquer destas circunstâncias censuradas por Séneca podemos evocar paralelos nos epigramas de Marcial, onde há mulheres que já casaram dez vezes para legalizar os adultérios e por necessária obediência à lei Júlia (6.7), onde se diz que só é casta a mulher que, sem se dar, também se não nega ${ }^{23}$, ou se demonstra aos maridos a perfeita inutilidade dos esforços em guardarem as esposas, pois elas encontrarão sempre meios de satisfazer a desvergonha ${ }^{24}$.

Sem esquecer a herança da literatura grega, nem a da comédia plautina, há estudos que apontam, com pertinência, para os antecedentes literários do quadro pintado por Marcial relativamente aos assuntos do amor: no caso particular da literatura latina, a poesia elegíaca. Aí se encontrariam, embora sob os topoi do código que rege o género, as sementes literárias das mulheres devassas, dominadoras, insensíveis e exploradoras que perpassam pela obra de Marcial, mas também dos jovenzinhos cruéis que conquistam o amor do poeta e depois, cientes do poder que detêm, se furtam, e esquivam, e magoam, num jogo de sedução e de traições que revolta mas prende, que tece, na insatisfação e no desejo, as amarras do corpo e os laços do afecto. Assim parece ser, de facto, pois, na poesia de Marcial, há muito do perfil da amada elegíaca, com os seus furta, a sua insensibilidade e depravação, a sua auaritia e falta de escrúpulos, a sua atitude de manter pela rédea curta do amor e do desejo o amado que a ela se submete, ainda por cima gostosamente, no que se convencionou chamar o seruitium amoris, preso nos uincula e disposto ao obsequium, rejubilando enfim com uma ou outra migalha de amor em noites em que a porta da casa da domina não ficou fechada e em que a cama dela não recebeu nenhum rival de bolsa mais provida, abrindo-se ao invés para as rixae amoris, para a batalha dos corpos e o apaziguamento dos sentidos. Como também há muito do Marathus de Tibulo, belo, jovem, inconstante e venal, que tão depressa se rende à sedução dos amores pelo sexo oposto, como, falta imperdoável, se deixa comprar pela bolsa abonada de um velho libidinoso e repelente, nos escravos de Marcial que se aproximam, à voz do senhor, com o vinho e as rosas e o encanto dos cabelos longos e da pele macia, para logo se esquivarem ou retardarem o prazer em cruéis negaças, ou, supremo desalento, fazerem o poeta sentir o peso do passar dos anos na necessidade de implorar o amor àqueles que outrora tudo lhe davam sem que ele nada tivesse de pedir (12.71).

\footnotetext{
${ }^{22}$ Ben. 3.16.2. Cf. tb. Tranq. 12.4 e De Matrimonio F 36 Vottero = F 68 Haase.

23 4.71. Séneca assevera que só é casta a mulher deformis (cf. Ben. 3.16.3: Argumentum est deformitatis pudicitia).

${ }^{24}$ É o que se depreende e.g. de 11.7 ou, ainda, de 11.16.9-10.
} 
Há, pois, algo que não podemos iludir: a perspectiva conservadora de Marcial, que, em coisas de sexo, entende que a mulher deve ser inferior ao marido, em riqueza e em cultura ${ }^{25}$, que olha desconfiado para todos os que não têm, como ele, o ar façanhudo de quem é macho (10.65), ou os que lançam mão de adereços ou artifícios que cataloga, obviamente, como pouco viris, como pintar o cabelo, usar perfume, jóias ou roupa de cores inadequadas, bem como depilarem- $\mathrm{se}^{26}$, que entende e aplica a escala rígida da hierarquia do que é degradante no sexo: Marcial gaba-se de ser daqueles que só assume o papel activo, e tudo o que saia da estrita penetração fálica de mulheres ou de rapazinhos é por ele considerado aviltante e, por isso, frutífero ingrediente para a feitura dos seus epigramas. De facto, no terreno interdito dos $10 \%$ de epigramas que, como J.P. Sullivan escreve, "would be regarded as obscene nowadays" 27 , jamais somos levados a cair no erro grosseiro de identificar sexo, ainda por cima com traços de irreprimível desbragamento, com amor ou, mais ainda, de tomar como verdade o que é convenção literária, topos de género ou herança de tipos e recursos técnicos de outras épocas que se imitam e renovam.

Lida e relida a obra do poeta, o que encontramos não sei se é alguma vez aquilo a que possa chamar-se amor. Aqui e além, talvez, uma ânsia de amar ${ }^{28}$ mas, ainda assim, por vezes ligada a objectivos tão prosaicos, como sugerir a um patrono que, se quer que ele escreva como Vergílio escreveu, the deve dar um escravo como Aléxis ${ }^{29}$. Aqui e além, o desenho ideal da mulher que quereria amar, mas que adivinha, desenganado, que nunca encontrará, uma mulher que saiba ser amante sem deixar de ser casta ${ }^{30}$. Mas mesmo esse ideal que, já de si, aponta para um código de normas morais que só se pode infringir no segredo das alcovas e na salvaguarda das aparências, aparece outras vezes maculado de exigências prosaicas e soezes, como quando declara não querer mulheres nem muito difíceis nem demasiado fáceis, para não sofrer demasiado

${ }^{25}$ Leia-se 8.12: Perguntam porque não quero uma esposa rica / desposar? Não quero ser esposa da minha esposa. / Que a mulher seja, Prisco, inferior ao seu marido: / de outro modo não há igualdade entre mulher e homem. Ou 11.19, onde, para não casar com Gala, Marcial dá a razão de que ela é muito literata. Já em 2.90, enumerando a Quintiliano o que lhe basta para ser feliz, inclui uma mulber pouco erudita (v.9: non doctissima coniunx).

${ }^{26} 1.96 ; 2.12 ; 29 ; 62 ; 3.43 ; 74 ; 4.36 ; 5.23 ; 41 ; 61 ; 6.55 ; 64 ; 8.47 ; 9.27 ; 10.65 ; 12.38 \ldots$

${ }^{27}$ Martial. The unexpected classic. Cambridge, Univ. Press, 1991, 185.

${ }^{28}$ Sobre o tema, v. Walter de Medeiros, "O poeta que buscava o amor", Humanitas 35-36 (1983-84), 87-103, e José Luís Brandão, 'Da quod amem'. Amor e amargor na poesia de Marcial. Lisboa, Colibri, 1998.

${ }^{29}$ Cf. 8.55 (embora Marcial se engane ao atribuir a Mecenas a oferta de Aléxis a Vergílio: foi Asínio Polião quem lho deu de presente). V. tb. 5.16.12; 8. 73.10.

30 10.47.10: non tristis torus, et tamen pudicus (um leito nupcial não austero, e contudo honrado). Em tom mais ligeiro, em 11.104.21-22, assevera que a mulher que queira viver com ele pode ser uma Lucrécia de dia mas, de noite, tem de ser uma Laís. 
nem se saciar depressa (1.57.2-4), quando rejeita liminarmente casar-se com uma mulher mais rica do que ele, por receio de ocupar no matrimónio posição de inferioridade (8.12), ou unir-se "à que pede alto preço e recita palavras caras" (9.32.5), quando revela que não deseja uma mulher nem muito magra nem muito gorda (11.100), mas que, acima de tudo, a quer bela, mesmo que escrava (3.33), ou quando conclui a 'lista' dos seus requisitos para uma vida feliz com o desejo de um puer que se conserve imberbe por muitos anos, a par de uma puella que possa partilhar com esse escravo (2.42).

Aqui e além, o amor dos jovens. Mas que amor? O do entendimento, difícil e fugaz, mas ainda assim possível, dos corpos, mas de que nada resta até ao momento em que, de novo, os sentidos se tornam exigentes e reclamam, raras vezes com ternura e amiúde com crueldade (5.46), a saciedade dos sentidos, a obediência às pulsões do instinto; mas nada mais. Sucedem-se, nos epigramas, os escravos que deseja, os escravos que possui, os escravos que cobiça aos amigos, com olhar lúbrico, os escravos que os amigos lhe cobiçam, e que ele vigia, com olhar duro; desfilam os nomes de um Diadúmeno, o dos beijos que rescendem aos mais raros perfumes, mas que nada concede sine inuidia ${ }^{31}$, de um Catacisso (9.93), de um Díndimo (5.83; 10.42; 11.6), de um Hilo ou de um Ligdo, que dantes nada negavam e agora tudo recusam $(4.7 ; 11.73 ; 12.71)$, ou de um Telésforo, grata quies, blanda cura $^{32}$. Mas todos eles são, de certo modo, simples retalhos da imagem que o poeta tem do puer ideal, belo, jovial, a tez branca e os cabelos longos e lisos, o olhar luminoso e os lábios vermelhos, indiferente às solicitações de todos, pueri ou puellae, dominando a arte de negar o que se deseja e de obter o que se não quer dar (4.42), em jogo do gato e do rato que, se apetece ao poeta e o excita, bem depressa lhe deixa na alma o travo amargo da solidão, o veneno insidioso do desencanto e do desencontro, aquele que transbordará da verificação magoada do dístico Difficilis facilis, iucundus acerbus es idem: / nec tecum possum uiuere nec sine te $e^{33}$, aquele que encherá a taça dos anos bebidos até ao fim, na consciência da finitude do que é humano e da fugacidade de tudo o que pensamos possuir. $\mathrm{E}$ aí, quando esse sentimento da efemeridade da vida e do amor o toma, é em tom horaciano que glosa o motivo do carpe diem, em libações que enchem o momento que passa, coroado das rosas ou dos nardos que num instante deslumbram e num instante murcham, ciente de que pouco há que valha a pena, e mesmo isso em breve os deuses no-lo podem tirar ${ }^{34}$.

${ }^{31}$ 3.65.10: sem relutância. Cf. 5.46; 6.34 .

32 11.26. 1: meu grato remanso (...) meu brando tormento. Cf. tb. 11.58 .

33 12.46(47): És difícil e fácil, alegre e amargo ao mesmo tempo: / não posso viver contigo... nem sem ti. Neste dístico é evidente o eco de Ovídio, Am. 3.11b, 39: sic ego nec sine te nec tecum uiuere possum (trad. de Carlos Ascenso André, Lisboa, Cotovia, 2006: Assim, nem sem ti nem contigo sou capaz de viver).

${ }^{34}$ Tomem-se como exemplos, não únicos, mas assaz significativos, 2.59; 5.64. 
Não é de amor que falam os Epigramas. Ninguém que persista em acreditar que a vida nada significa sem a bênção do amor encontrará na poesia de Marcial o que quer que seja que lhe fale ao coração. Apenas a crueza dos sentidos que, satisfeitos, logo esquecem quem lhos satisfez. E uma mente conservadora que, afinal, muito contribuiu para que a visão que os vindouros receberam da vida e da sociedade romana do séc. I seja a de um enorme fresco de devassidão e desregramento. É que a caricatura tomou-se por retrato e a árvore pela floresta. Sem nada ter mudado com tais denúncias e censuras - os escritores cristãos acusam e censuram, grosso modo, o mesmo que os moralistas e satíricos pagãos - o que daí resultou foi um juízo de valor a nosso ver deformado, assente em leituras apressadas e parcelares, abrindo espaço para a picante e, por isso mesmo, atraente ficção, bem como para a suculenta matéria cinematográfica que povoa o imaginário do vulgo, com as intermináveis orgias em que todos participavam sem nenhum constrangimento, regadas de vinho e empanturradas de comezainas, numa espiral de enfado que era mister fustigar constantemente com novos prazeres, cada vez mais rebuscados e desviantes, quer fosse nos leitos, quer nas bancadas do anfiteatro. 


\title{
Marcial e a Urbe: O MEIO FÍSICO E HISTÓRICO-SOCIAL DOS EPIGRAMAS
}

\author{
José Luís Lopes Brandẽo \\ Universidade de Coimbra \\ Centro de Estudos Clássicos e Humanísticos
}

Marcial tem sido considerado com justiça o poeta de Roma e de Bílbilis. Com efeito, da sua pena saiu um retrato sensual das ruas da Urbe, dos edifícios, dos espaços de convívio públicos e privados. Não se trata de uma descrição arqueológica, do género de um catálogo de museu, mas sobretudo de um testemunho vivo das gentes que povoavam tais espaços, desde o rico, ou novo-rico, ao mais miserável dos arruinados; desde o mais poderoso patrono ao último dos clientes, desde o romano da mais pura gema aos mais extravagantes provincianos, desde as mais nobres matronas às mais repelentes rameiras. Marcial consegue captar com argúcia instantes, traços distintivos, costumes, tragédias pessoais disfarçadas, pobreza envergonhada e transmitir ao leitor os quadros mais emotivos, ou, de maneira fria, os mais degradantes, que acaso trouxeram má fama ao poeta, apesar dos seus protestos de que não o deviam julgar pelo que escrevia. É um retrato poético do que observava. Por isso, Marcial é considerado il poeta di Roma vivente - como dirá Enrico Paoli. Reflecte a Roma imperial, com a sua sociedade piramidal e a monumentalidade de cariz totalitário, acumulada sobretudo durante o período dos Júlio-Cláudios e dos Flávios. Neste particular, a literatura está unida à arquitectura e à religião numa representação activa do império. Mas também se apresenta o reverso da medalha: a Roma pobre, das vielas e das insulae, continuamente ameaçadas pelas derrocadas ou pelo fogo. Por outro lado, Marcial é também o poeta de Bílbilis, pelos rasgados elogios que tece à sua pátria na Hispânia Tarraconense, e pela reiterada evocação da cidade natal como modelo de vida, isto é, como uma alternativa à Urbe romana.

Como na composição dos livros a uariatio é norma, não é muitas vezes fácil encontrar padrões e revela-se tarefa árdua abarcar a totalidade da obra, mas podemos verificar que diversos topoi se repetem de forma esparsa e que há alguns opostos em luta na obra do poeta.

\section{Um poeta no centro do mundo - fascínio e cosmopolitismo}

Enquanto capital de um vasto império, Roma é atractiva pela sua beleza e pela sociedade cosmopolita. De modo que, ao chegar à Urbe, o jovem poeta não podia deixar de se sentir fascinado pela grandiosidade das construções de Nero e havia de cantar a obra restauradora dos Flávios, erguida depois da guerra civil de 68-69 d.C. Roma, enquanto entidade divina e material, era como que uma 
representação, um microcosmo do império - ideia que presidiria a construções sumptuosas, como a Domus Aurea, o célebre palácio de Nero, elevado depois do incêndio de 64, mas que estará igualmente presente no anfiteatro dos Flávios, onde se pode encontrar gente de todas as proveniências, como veremos adiante (Spect. 3).

Marcial transmite a universalidade da Urbe, a «deusa das terras e das gentes» (12.8.1), na sua missão integradora e civilizadora, que levou a outrora pequena cidade a ganhar a hegemonia no Lácio, a integrar progressivamente a Itália no ager romanus, para depois se expandir pelo Mediterrâneo e se tornar no centro de um vasto império ${ }^{1}$.

A influência da Urbe irradia para todo o Império através das vias e da segurança dos mares. Marcial consegue perceber o benefício da pax romana, uma facilidade de transacção cultural que poderíamos comparar à internet dos nossos dias. Em Roma, o poeta sente-se no centro do orbe e, desse lugar privilegiado, pode dirigir-se ao mundo. A vocação universalista e civilizadora da Urbe é também a razão do sucesso do poeta, uma vez que possibilita que os seus versos sejam lidos e apreciados, em tempo útil, na Gália (7.88), ou mesmo em terras mais distantes, como ele próprio proclama: Hic est quem legis ille, quem requiris, / toto notus in orbe Martialis (1.1.1-2) («Este é aquele que lês, aquele que reclamas, / Marcial, conhecido em todo o mundo...»). Ou, de modo semelhante: Ore legor multo notumque per oppida nomen / non expectato dat mibi fama rogo (3.95.7-8) («Sou lido por muitas bocas e um nome conhecido através das cidades / me dá a fama, sem esperar pela pira») $)^{2}$.

E se a metrópole era representação da pluralidade do império, também as províncias procuravam ser o espelho de Roma. Ninguém estranha que o poeta considere que Marcela, sendo de Bílbilis, nada fique a dever em termos culturais às mulheres da Urbe (12.21), apesar da adulação que possa existir em tais versos. As cidades da Hispânia são o berço de glórias literárias que, tal como os naturais de outras cidades itálicas, singraram em Roma (1.61). O próprio Marcial é o produto da esmerada educação que se obtinha já nas províncias, e em concreto na Hispânia, e da importância que algumas regiões vinham tendo na vida económica, cultural e política do Império. Já em Roma, em 68, assiste à chegada da notícia de que um novo imperador, Galba, tinha sido aclamado na Hispânia, enquanto Nero era abandonado por parte do senado e da guarda pretoriana. Outros breves imperadores se seguiram, demonstrando o poder de forças externas à Urbe: Otão, que governara a Lusitânia durante dez anos, apoia-se na guarda pretoriana, Vitélio é aclamado pelos exércitos da Germânia, e Vespasiano é proclamado imperador a oriente. $\mathrm{O}$ poeta faz inclusivamente

\footnotetext{
${ }^{1}$ Vide Robert 2004b 69-86.

${ }^{2}$ Cf. 6.64 .
} 
o elogio de Otão, que se suicidou para evitar o prolongamento das agruras da guerra civil, apesar de dispor ainda de tropas dispostas a continuar a luta contra Vitélio e seus partidários (6.32). Otão redimiu assim com a morte uma vida desregrada e acabaria associado à propaganda dos Flávios na altura de Vespasiano aceder ao poder ${ }^{3}$. Tornava-se claro na época que havia uma luta de várias forças: exércitos das províncias, senado, guarda pretoriana. Como diz Tácito (Hist.1.4), a crise revelou um arcano do império: o imperador podia ser eleito em qualquer outra parte que não Roma. O Exército, força irradiadora de poder, torna-se agora também centrípeta, na participação política, como sugere Plutarco (Galb. 1.6). Mas é também meio de difusão de cultura que Marcial não descura, quer pelos amigos que tem nas patentes elevadas do exército, como o amigo Pudente que detém o cargo de primipilo (6.58), quer pelo simples soldado que leva no bornal os epigramas para as mais distantes províncias.

\section{Roma "em carne viva"}

Atento ao mundo em que vive na busca de inspiração para a sua obra, Marcial capta a realidade e representa-a através do olhar de poeta epigramático. E nos quadros representados figuram caracteres, virtudes e vícios, tipos sociais, grupos, profissões. O leitor depara com alguns dramas humanos, transmitidos umas vezes de forma crua e irónica, outras vezes, empática, e a maior parte das vezes espirituosa, como manda o género: o epigrama, pela sua tradição, é a escolha adequada para descrições concisas, argutas e contundentes. Marcial deixa-nos, por isso, um retrato ao mesmo tempo realista e divertido da vida social da Roma dos Flávios: ora uma crónica mais ou menos ligeira, com sabor a reportagem sensacionalista ou a frivolidades de revista cor-de-rosa ${ }^{4}$, ora os aspectos mais dolorosos da vida humana, as feridas sociais, as vicissitudes do corpo e da alma - daí usarmos aqui a expressão "em carne viva", para salientar ao mesmo tempo a vivacidade picante e o realismo mórbido das feridas abertas. A mordacidade e a sátira vão alternando com a sensibilidade e a empatia com o sofrimento. É uma poesia que, apesar da caricatura, mantém o sabor humano, como salienta o poeta (10.4.10). Vale a pena centrarmo-nos em alguns aspectos mais representativos.

\subsection{Entre o ter e o ser}

Um dos problemas que mais preocupa a humanidade é o da procura dos meios da sobrevivência. Marcial parece obcecado com o problema da

\footnotetext{
${ }^{3}$ Segundo Suetónio (Ves. 6.4), teria circulado uma carta supostamente daquele breve imperador a exortar Vespasiano a vingá-lo e a assumir a defesa do império.

${ }^{4}$ Vide Pimentel 1992 165-186.
} 
distribuição da riqueza e da pobreza na sociedade; não como um paladino da luta pela igualdade social dos tempos modernos, mas como um cavaleiro conservador, preocupado com o perigo da subversão da ordem na sociedade romana. Em Roma, o poder político e social estava tradicionalmente associado à riqueza. Desde épocas recuadas que nos comitia centuriata votavam em primeiro lugar os mais ricos, os da primeira classe. Nos tempos do poeta, o status de senador e cavaleiro estava dependente da posse de um determinado valor patrimonial, um milhão de sestércios para o primeiro e quatrocentos mil para o último. A ordem senatorial tem o seu estatuto e património tradicionalmente ligados à posse da terra. Para um cavaleiro a indústria e o grande comércio são recomendados 5 . Mas um naufrágio, por exemplo, pode arruinar um homem rico ${ }^{6}$. As actividades assalariadas e laborais são consideradas desonrosas para um homem ilustre. Por vezes, os imperadores tinham de subsidiar indivíduos destas classes para que não perdessem o estatuto. Marcial zurze, com voz moralizante, as situações que subvertem a realidade social. Critica sobretudo os novos-ricos, que fintam a hierarquia social e depois desbaratam o património com extravagâncias de mau gosto. Sente amiúde a evidência de todos os tempos de que os homens das letras são mal remunerados, enquanto outras profissões alcançam honorários invejáveis. Denuncia quer as situações de ostentação, quer as da ruína culposa, quer certos expedientes indignos usados para conseguir singrar na vida.

Um dos principais alvos de Marcial são os caçadores de heranças. A caça à herança ou ao dote é um fenómeno comum em Roma por causa das disposições testamentárias que garantiam a propriedade privada e defesa do direito de cada um dispor dos bens a seu desejo. Assim a captatio tornou-se topos dos poetas satíricos ${ }^{7}$. Os alvos são mulheres ricas ou velhos sem herdeiros. É bastante conhecido e repetido, como paradigmático do género cultivado por Marcial, o epigrama sobre as núpcias de Maronila, que se torna atraente por estar tísica, e, por isso, perto da morte (1.10); ou o caso de Névia que, para atrair um pretendente, usa de publicidade enganosa: tosse de forma exagerada (2.26) - situações caricatas que reflectem a realidade dos expedientes a que se podia recorrer para sobreviver na Urbe. Dada a protecção de que gozava a propriedade da mulher romana, surge a suspeita de que certos homens vendem os seus favores sexuais em troca do dinheiro das mulheres - é o que se deduz da censura feita a Basso, por gastar a sua potência sexual com rapazinhos, subtraindo à esposa o vigor que ela tinha pago com o dote (12.97), da ventura

${ }^{5}$ Vide Marache 1961b 12-13.

${ }^{6} \mathrm{Cf}$. Petrónio, Satyr. 76.

${ }^{7} \mathrm{O}$ topos foi aparecendo em Horácio (Sat. 2.5), Petrónio (117), Pérsio (5.73), Juvenal (por ex. 1.37-41). Vide Sullivan 1991159 ss. 
de Gélio, que casou com uma velha rica (9.80), ou da desgraça de Matão, que para sobreviver tem comércio carnal com mulheres, contra os seus hábitos (6.33). E, dadas as disposições legais sobre o adultério - a restauração por parte de Domiciano da lex Iulia de adulteriis coercendis promulgada por Augusto -, certas mulheres optam por casar com sucessivos amantes (6.7; 6.22). Na Roma antiga, o homem tinha só direito ao uso do dote enquanto durava o casamento, e tinha de o devolver em caso de divórcio ${ }^{8}$. Por isso, Proculeia descobre que é mais lucrativo abandonar o marido por causa da despesa com a brilhante carreira dele (10.41). Por outro lado, a morte de esposas ricas é uma fonte de rendimento $(2.65 ; 5.37 ; 10.43)$, pelo que estas podem tornar-se vítimas de envenenamentos $(4.69 .3 ; 12.91)$.

Os velhos sem herdeiros são também vítimas naturais. Os caçadores de heranças enchem-nos de presentes na esperança de verem o seu nome no testamento $(8.27 ; 9.8 ; 11.44 ; 11.67)$. É a síndrome de Eumolpo do romance de Petrónio (Sat. 116-141), que, ao saber que, em Crotona, abundavam os heredipetae, se faz passar por velho rico para conseguir benesses. O próprio Marcial se inclui no grupo: troça do seu próprio desejo frustrado de ser mencionado num testamento $(5.39 ; 9.48 ; 10.98 ; 12.73)^{9}$, ou de receber uma herança $(10.97)$.

Outro tópico fértil são os jantares oferecidos e o parasitismo que existia nesse contexto, como no caso de Sélio $(2.11 ; 2.14 ; 2.27)$, de Vacerra (11.77) ou Menógenes (12.82), que procuram por todos os meios receber um convite. Era sinal de um certo êxito social ter muitos convites ${ }^{10}$, pelo que alguns fingem ser bastante requestados $(5.47 ; 12.19)$. Mas também ficaria bem socialmente não mostrar demasiado entusiasmo ou até uma certa contrariedade em jantar fora, como sugere a denúncia por parte do poeta de atitudes desdenhosas que soam a hipocrisia $(2.69 ; 6.51)$. Mas há sempre os que não têm noção das conveniências e chegam demasiado cedo, deixando o anfitrião embaraçado (8.67).

A verdade é que ser convidado para jantar era uma forma de subsistência, como demonstra o caso de Filão: jurava que nunca jantava em casa, porque, quando não tinha convite, não jantava (5.47). Alguns aproveitam para fazer provisões, roubando comida nos banquetes $(3.23 ; 7.20)$. Este topos está, pois, relacionado com as obrigações padronizadas entre patrono e cliente. A provisão de comida é uma das formas primitivas de suporte dos dependentes, que depois se transforma em dádiva de dinheiro: a sportula. A “clientela” era uma verdadeira instituição em Roma e, ao mesmo tempo, uma forma socialmente digna de um poeta pobre ganhar a vida. Uma vez que o trabalho remunerado

\footnotetext{
${ }^{8}$ Vide Sullivan 1991161.

${ }^{9}$ Outros exemplos de caçadores de heranças: $2.76 ; 4.56 ; 4.70 ; 6.62 ; 6.63 ; 7.66 ; 8.44 ; 9.48$; 9.82; 9.88; $11.55 ; 11.83$.

${ }^{10}$ Etão considera como maldição ter de jantar em casa três dias seguidos (12.77).
} 
era considerado pouco acima de comportamento escravo, quem não tivesse meios de subsistência e quisesse manter o status tinha de optar pelo recurso à "caridade" de um patrono poderoso. E Marcial envereda relutantemente por esta prática, que juridicamente tem uma origem servil ${ }^{11}$. É que o papel do cliente sofreu transformações desde a República: nessa fase, o vínculo entre patronus e cliens consistia numa relação moral bilateral baseada na fides; o cliente encontrava protecção no patrono e este precisava do cliente, inclusivamente para apoio armado. Com o advento do Império, a ligação moral deixa de existir, porque o imperador é politicamente o único verdadeiro patrono, pelo que resta só a ligação económica ${ }^{12}$. Como o patrono pouco tem a esperar dos seus clientes, a relação paternalista torna-se uma espécie de vassalagem para garantir a sobrevivência e ritualiza-se. Há dois momentos fortes do dia em que se efectua o encontro ritual entre os patronos e os clientes: a salutatio matinal e a cena, se o cliente tiver a sorte de ser convidado. Em troca, o cliente recebe a tal quantia que lhe permite sobreviver na Urbe (3.30), sem que isso constitua um estigma social. Mas, à excepção dos dias especiais, como o aniversário do patrono, em que a quantia pode aumentar consideravelmente (10.27), o valor da sportula ${ }^{13}$ é escasso $(3.7 ; 6.88 ; 8.42)$, pelo que o estafado cliente se vê obrigado a correr, para saudar vários patronos ${ }^{14}$.

Domiciano, na sua tentativa de apagar de Roma os traços neronianos ${ }^{15}$, emitiu legislação para transformar a sportula, cuja tarifa remontava a Nero (um cesto de comida ou dinheiro), na dádiva de um jantar. Mas a nova disposição não agradava nem aos patronos, que ficavam vinculados a ter à mesa os seus dependentes, nem aos clientes, que necessitavam de dinheiro vivo. Tal circunstância é repetidamente tratada no livro III dos Epigramas. Afastado de Roma, em Forum Cornelii (Ímola), com a justificação de não poder suportar mais o aborrecimento da toga (3.4.6), o poeta glosa o mote do descontentamento gerado pela abolição da sportula ${ }^{16}$. Em vez de um jantar, o poeta sugere a atribuição de um salário (3.7). Mas a disposição de Domiciano acaba por ser esquecida e a anterior prática retomada, como mostra o facto de o poeta continuar a referir a espórtula nos livros seguintes.

${ }^{11}$ Vide Marache 1961 38-53; Mohler 1967 241; Augello 1968-69 259-260, e n.156.

${ }^{12}$ Vide Robert 2004a 48 ss.

${ }^{13}$ Sob tal designação se podem incluir os presentes oferecidos durante o jantar, como sugere Plínio (Ep. 2.14.4), e nesse caso é comparável com os xenia ou apophoreta; ou pode ser dada durante os banhos (Marcial 8.42), ou durante a salutatio (Juvenal 1.95-102; 120-122;127-128): vide Mohler 1967 251ss.

${ }^{14}$ Cf. 1.80: Cano morreu depois de receber a sportula: foi esta que o matou... porque foi só uma.

${ }^{15}$ Vide Augello, 19968-69 263.

${ }^{16}$ A abolição temporária da sportula é um dos temas recorrentes neste livro: 3.7, 3.14, 3.30, 3.60. Vide Sullivan, 1991, 31. 
O poeta acusa repetidamente a humilhação e o cansaço resultante desta veneração (o termo que usa é colere em 2.55) dos patronos. Queixa-se do facto de o cliente, ao romper da aurora, ter de se dirigir aos átrios dos patronos para a salutatio matutina, a tremer (Cf. 9.92.5); da obrigação de ir vestido a rigor, isto é, de toga, peça sobre a qual Marcial faz passar uma ideia de desconforto (3.4.6; 12.18.6.); da humilhação de ter de saudar o patrono como dominus et rex, títulos tirânicos que o poeta se mostra renitente em usar (Cf.1.112; $2.68 .2 ; 10.10 .5)$, mas o tratamento pelo nome próprio em vez de por dominus pode implicar a perda da espórtula (6.88). Nesta pirâmide social cujo vértice é o imperador, os patronos do poeta são por sua vez clientes de outros mais poderosos, situação com a qual Marcial não deixa de ironizar $(2.18 ; 2.32)$. E no livro X confessa-se exausto ${ }^{17}$; o que deseja é levar uma vida frugal e simples, longe do afã citadino (10.47), e dormir sossegado (10.74). Irá encontrar essa paz, pelo menos inicialmente, com o regresso a Bílbilis, a sua terra natal ${ }^{18}$.

Não se estranha que para o cliente Marcial uma fonte privilegiada de inspiração seja, pois, a situação de banquete: a decoração da sala de jantar, a beleza dos jovens escravos, os odores requintados, os perfumes, as flores, os poemas e a música. Era natural que os mais ricos tentassem imitar os requintes dos banquetes de Nero na chamada cenatio rotunda da sua Domus Aurea, cuja abóbada rodava continuamente à semelhança do universo, e cujo artesoado do tecto permitia derramar flores e perfumes sobre os comensais ${ }^{19}$. Os pratos descritos por Marcial constituem uma fonte de informação sobre a cozinha romana. $\mathrm{E}$ as atitudes de anfitriões e de convivas captam a atenção do poeta epigramático. Um dos temas diz respeito à mesquinhez dos patronos, que por vezes faziam distinções nos banquetes entre os clientes, ou entre eles próprios e os clientes, no que toca ao requinte da comida e da bebida servidas. Ceciliano devora cogumelos enquanto os convidados ficam a ver, pelo que o poeta considera que tal gula é digna do cogumelo que Cláudio comeu, numa alusão à morte deste imperador, em 54 d.C., alegadamente envenenado por um cogumelo, a mando de Agripina ${ }^{20}$.

Também a avidez dos convidados é objecto de censura. O mesmo Ceciliano (nome certamente fictício, como é prática de Marcial para zurzir nos vícios) aparece associado ao furto de comida nos banquetes ${ }^{21}$. A situação

${ }^{17} 10.56 ; 10.82$.

${ }^{18}$ Vide Pimentel 1993 249-261; Brandão 1998 151-172.

${ }^{19}$ Cf. Suetónio, Vida de Nero 31.

${ }^{20}$ 1.20. O tema, comum nos poetas satíricos, é frequente em Marcial (2.43; 3.60; 4.68; 4.85; $6.11 ; 10.49)$. Também Juvenal (1.139) representa o cliente a sofrer a indignidade de lhe ser negado um convite, ou de receber uma ração de comida inferior à do patrão ou vinho de pior qualidade. Plínio, o amigo do poeta, deplora o mesmo vício e diz-se incapaz de incorrer em tal mau gosto (Ep. 2.6). Vide Howell 1980 151-154.

${ }^{21}$ 2.37.10-11: Vllus si pudor est, repone cenam / cras te, Caeciliane, non uocaui 'Se tens alguma 
é mais indecorosa ainda se o furto se destina a ser vendido, no dia seguinte, na Suburra (7.20). A gula é objecto fácil de caricatura (11.86; 12.41). O vício é ilustrado com referência jocosa a um nome que para qualquer romano evocava imediatamente a boa cozinha, Apício: diz o poeta que ele era tão guloso, que, depois de quase arruinado, não podendo suportar perspectiva de passar fome e a sede, bebeu - extrema gulodice! - veneno ${ }^{22}$.

$\mathrm{O}$ banquete pretende por tradição favorecer o ambiente de tertúlia. Mas acontecia que o cliente tinha amiúde de se submeter à tirania de ouvir recitar volumes descomunais $(3.45 ; 3.50)$ e aplaudir a contragosto as prepotências dos novos-ricos (3.82). Pelo que, durante o jantar, manifestam-se as atitudes bajulatórias ao anfitrião $(6.48 ; 12.82)$. O próprio poeta reconhece que o conviva/cliente perde a liberdade de expressão ${ }^{23}$. A estes banquetes opõe o convívio sem artifícios, com pratos simples $(5.78 ; 10.48 ; 11.52)$, onde o conviva se sinta livre e não tenha de ouvir récitas intermináveis (5.78.23-25)24. $\mathrm{E}$ no que toca a requintes dos sentidos, o poeta prefere «um jantar que possa retribuir» (12.48.18).

Em suma, sob o disfarce da caricatura, a abordagem é moral e pessimista. Homens, provavelmente arruinados, que, com os seus bens, perderam todo o amor-próprio: Sélio desfaz-se em bajulações e, esgotado, corre a todos os locais em busca de quem o convide, para, ao fim da tarde, deambular só por um pórtico deserto $(2.14 ; 2.11)$; Menógenes suja-se de pó ao devolver a bola a um poderoso, para receber um convite para jantar (12.82); Tuca come avidamente e até já se mostra feliz quando lhe chamam alarve (12.41); Ceciliano não se inibe de roubar comida no banquete, porque a antecipação da fome de amanhã já lhe é mais dolorosa que a vergonha de hoje (2.37; cf.3.23); Santra chega ao quarto cansado com toda a comida que conseguiu palmar, para no dia seguinte a ir vender (7.20); Filão, mais orgulhoso, não admite, mas passa fome quando não o convidam (5.47); Cota, com a desculpa de furtos, vem descalço e traz um séquito composto só um escravo (12.87); Etão necessita tanto de um convite para jantar, que a sua falta é uma maldição dos deuses (12.77). É degradante à vista o cortejo de trastes de Vacerra, que está a mudar de casa com a mãe e a irmã (12.32). De qualquer modo, é preciso ter em conta que se trata de tradição literária: certos retratos

vergonha na cara, restitui o jantar; / não foi para amanhã, Ceciliano, que eu te convidei!'.

22 3.22. Trata-se de uma anedota, também transmitida por Séneca (Dial. 12.10.8-10), sobre o fim de Apício, o provável autor do conhecido livro de culinária (De re coquinaria), que, não podendo suportar a ideia de viver com apenas dez milhões de sestércios, se suicidou. Vide Sullivan 1991 100-101. O nome de Apício é também associado ao daqueles que não suportam não ter convites para jantar (2.69.3-4).

${ }^{23}$ 9.9.4: Liber non potes et gulosus esse 'Não podes ser livre e glutão ao mesmo tempo!'

${ }^{24}$ Cf. 11.52.16. 
de indigência extrema (como 1.92) podem ser mais uma forma de glosar o mote do que expressão da realidade ${ }^{25}$.

A crueldade da troça em alguns dos quadros sugere que a pobreza é resultado de culpa. Pode-se descortinar o topos da retórica contra a sumptuosidade, presente na crítica aos esbanjadores ${ }^{26}$ e em vocabulário relacionado com luxuria. Mas intensifica-se a censura quando se trata de mostrar o que não se é. Com efeito, em Marcial está patente o empobrecimento de um grupo em especial: uma classe nobre com a qual o poeta convive e na qual se inclui. São pessoas de gostos requintados e, por isso, dispendiosos. Assim, neste século I d. C., ao lado de libertos riquíssimos, surge uma ordem equestre arruinada. Entre os cavaleiros, há quem, apesar do aparato, tenha mesmo de empenhar o anel distintivo da sua classe (2.57). São pessoas que, habituados a privar com a nata da nobreza romana, continuam a cultivar o bom gosto. Mas, para um homem de gostos requintados e empobrecido, como Mamurra, uma visita às montras transforma-se num verdadeiro suplício (9.59; cf. 10.80). Quem se habituou a viver com sumptuosidade, dificilmente se habituará a uma vida simples, como demonstra a referida anedota sobre a morte de Apício. Em contraste, o liberto Sirisco herdou uma fortuna do patrono, mas desperdiça-a com gostos plebeus (5.70).

Como seria de esperar, numa sociedade que tem escravos, os libertos e novos-ricos são bastante atacados pelo poeta, sobretudo aqueles que procuram ostentar insolentemente as riquezas ou disfarçar os sinais da antiga escravatura (2.29). Zoilo é quem melhor incarna o liberto e novo-rico sumptuoso, luxurioso, cultor de falsas aparências, imbuído de mau-carácter e de mau gosto ${ }^{27}$. As suas extravagâncias durante o jantar recordam as de Trimalquião no Satyricon de Petrónio $^{28}$. Usurpou o status de cavaleiro ${ }^{29}$, e a ostentação frívola que marca a sua vida evidencia-se pelo tamanho do anel (11.37), pela excessiva mudança de roupa durante a cena (5.79), pelo esplendor das colchas do leito (2.16), pela envergadura da liteira ${ }^{30}$. Mas afinal tudo assenta em bases falsas. Marcial diz que ele é ladrão e escravo fugitivo (11.54) e um filho de ninguém, dada a sua origem servil, jogando com o facto de, à face da lei romana, um escravo não ter pais nem filhos (11.12). Marcial mostra-se preocupado com o status

${ }^{25}$ Vide Harris 2011 27-54.

${ }^{26}$ Cf. 3.62; 7.98; 11.66 .

${ }^{27} \mathrm{O}$ nome ocorre em vários epigramas desde o início da carreira de Marcial: 2.16; 2.19; 2.42; $2.58 ; 2.81 ; 3.29 ; 3.82 ; 4.77 ; 5.79 ; 6.91 ; 11.12 ; 11.30 ; 11.37 ; 11.54 ; 11.85 ; 11.92$. Marcial ter-se-á inspirado num crítico homérico do séc. IV a.C., alcunhado de Homeromástix, odiado pela sua maledicência. Para o estudo das influências literárias e históricas sofridas por Marcial na criação desta personagem, vide Kay 1985 92-93.

28 3.82. cf. Petrónio, 32-78. Vide Leão 2004 191-208.

${ }^{29}$ Cf. 3.29: possui os anéis distintivos desta classe.

${ }^{30}$ Cf. 2.81; Filipe (6.84) e Afro (6.77) têm uma atitude semelhante de ostentação. 
das ordens sociais e as tentativas de usurpação por parte dos libertos, como denotam os reiterados ataques contra os que violavam a lex Roscia theatralis, que impunha uma distribuição dos lugares no teatro de acordo com a posição hierarquia social ${ }^{31}$.

Os libertos imperiais são excepção à regra, porque se trata da intocável majestade do imperador, cujos mores eles espelham (9.79); mas também porque eles estão na sua correcta posição social: ao serviço do seu patrono, com as funções que este neles delega. Já Augusto usara escravos e libertos da sua casa para desempenhar tarefas administrativas no império, por não achar apropriado empregar homens livres em tais serviços. Mas com Cláudio os libertos atingiram um poder invejável à frente dos gabinetes da administração imperial. Na crise de 68-69, tanto Otão como Vitélio empregaram cavaleiros nestas funções; e Domiciano distribuiu-as entre cavaleiros e libertos (Suet. Dom. 7.2), apesar de, na Historia Augusta, se dizer que Adriano foi o primeiro a substituir os libertos por cavaleiros nas secretarias de ab epistolis e a libellis. $\mathrm{O}$ biógrafo Suetónio, membro da classe equestre, desempenhou estes cargos nos principados de Trajano e Adriano.

Objecto da atenção do poeta são as profissões, ou o modo como são desempenhadas. Segundo Marcial, a advocacia era uma profissão rentável: recebiam muitos presentes, sobretudo pela festa das Saturnais (4.46). E auferiam pagamento $(2.13 ; 8.16 ; 8.17)$. Já naquela época os litígios se arrastavam (7.65). É uma alternativa respeitável que os amigos aconselham ao poeta, e que este declina: usar os dotes retóricos para ganhar a vida como patronus ou causidicus. Entre os nomes provavelmente fictícios destes conselheiros (1.17; 2.30; 5.16), figura um aparentemente real: o do célebre retórico Quintiliano (2.90). No entanto, em 3. 38, Marcial apresenta a advocacia (a par da poesia) como geradora de fracos rendimentos, sobretudo se o praticante é um homem honesto. O poeta ataca tanto os advogados que se calam $(1.97 ; 8.7)$ como os palavrosos que se apoiam em vãos floreados retóricos: é bem conhecido o epigrama sobre o causídico que disserta sobre momentos dramáticos e grandes heróis da história romana, quando em causa está o simples furto de três cabrinhas (6.19). A Ceciliano, que pedira o tempo de sete clépsidras para falar, como tem muita sede, o poeta aconselha-o a beber da clépsidra (6.35). Há ainda aqueles que mudam de profissão, como Cípero, um antigo padeiro que agora defende causas (8.16), ou um advogado que se tornou agricultor e empobreceu (12.72).

Outra profissão ligada ao uso da voz e que envolvia muito dinheiro era a dos leiloeiros: Marcial aconselha-a como forma de singrar na vida, e, surpreendentemente, associa-a à de arquitecto no rendimento (5.56); constata

\footnotetext{
${ }^{31}$ Cf. 5.8; 5.25; 5.35; 5.38; 5.41. Vide Mouritsen 2011 91; 106 n.190.
} 
que, quando se trata de casamento, um leiloeiro é melhor partido que pretores, tribunos, advogados ou poetas (6.8). Por outro lado, expõe a falta de senso de alguns, que, por causa de tiradas infelizes no uso do seu proverbial espírito, acabam por prejudicar a venda $(1.85 ; 6.66)$.

A crítica aos médicos é comum na comédia, no epigrama satírico e mesmo em epitáfios. Em Roma, os médicos eram sobretudo gregos e abundava a incompetência e falta de controlo sobre a actividade. Plínio o Velho, na sua História Natural (29.1-29), produz uma longa diatribe contra os médicos, apontando a sua avidez por dinheiro, adultérios, assassínios por más práticas. Segundo este autor, Catão o Antigo advertira o filho de que os Gregos teriam jurado matar todos os "bárbaros" por meio da medicina e de que cobravam pagamento para se tornarem mais convincentes (Nat. 29.14) ${ }^{32}$. A troça centra-se pois nos médicos cujo desempenho tem o efeito contrário do esperado, com resultados muitas vezes fatais - um certo indivíduo antes era médico, agora é cangalheiro; mas o que faz como cangalheiro já o fazia como médico (1.47 e 1.30 cf. 8.74) -; ou com o agravamento dos sintomas - um dia o poeta estava adoentado, veio um médico com os seus cem discípulos, e o poeta foi apalpado por cem mãos gélidas do Aquilão: se antes não tinha febre, agora tem (5.9.). A hipérbole no tratamento do tema leva o poeta a sugerir que se pode morrer por ter sonhado com o médico (6.53). Mas há a ideia de que os clínicos podem matar deliberadamente por razões passionais (6.31) ou incapacitar permanentemente (11.74), e que seduzem as pacientes (11.71). Outro motivo comum é de que aproveitam para roubar os doentes (9.96).

O hábito de fazer a barba existiu em Roma sobretudo desde o século III a.C. O imperador Adriano (117-138 d.C.) restaurou a moda de usar barba, pelo que muitos o imitaram. Antes este costume era típico dos filósofos ${ }^{33}$. Era comum os romanos ricos terem barbeiros entre os seus escravos. Marcial compôs um belo epitáfio do seu escravo barbeiro com um encómio à sua arte (6.52). Podia-se também recorrer aos tonsores que ofereciam o seu serviço na rua ou às tonstrinae das taberna $e^{34}$. Os barbeiros são criticados, pela sua lentidão (7.83) ou pelo sofrimento que causam aos clientes (11.84). Com efeito, eram proverbiais os riscos que envolvia confiar o pescoço à navalha (3.74). Eram também censurados pelos elevados preços que cobravam ${ }^{35}$. Marcial critica o

${ }^{32}$ Vide Howell 2009 74-75; Hanson 2010 492-496. A referência aos Romanos como bárbaros reproduz o ponto de vista grego, recorrente por exemplo em Plauto (Asin. 11; Poen. 598; Tin. 19).

${ }_{33}$ Marcial, jogando com o sentido do "cínico", diz que um determinado seguidor desta escola, de tão sórdido que está, parece um verdadeiro cão (4.53).

${ }^{34}$ Marcial fala de uma tonstrix da Suburra (2.17): Non tondet, inquam. Quid igitur facit? Radit. "Não barbeia, digo-te eu. Que faz então? Esfola!".

${ }^{35}$ Cf. Juvenal 10.226. 
facto de um certo barbeiro atingir o estatuto de eques por benefício da sua patrona $(7.64 .1-2)^{36}$.

Os professores são ferozmente atacados, pelo barulho que fazem logo de manhã $(9.68$; cf. $5.84 ; 8.3)$ e porque o poeta é movido pela compaixão para com as crianças, submetidas à dureza da disciplina (10.62). Um conhecido relevo de Arlon mostra um mestre-escola empunhando um bastão. Mas é mais visível a hostilidade do poeta, que terá habitado nas proximidades de um destes professores, do que a desconsideração social de que eram objecto e os parcos rendimentos que auferiam (Molina Sánchez 2003 213ss).

Estas profissões são talvez as mais representativas na obra do bilbilitano. Mas muitas outras ocupações figuram nos epigramas, como prostitutas, taverneiros, agricultores, vendedores ambulantes, dançarinas, etc. E nem sempre as actividades honestas são as mais bem remuneradas. $\mathrm{Na}$ cidade, prosperam os delatores, os caluniadores, os fraudulentos, os traficantes, os devassos, os mestres de gladiadores (11.66; cf. 4.5. e 6.50), o deleite de qualquer poeta epigramático ${ }^{37}$.

Marcial reflecte, pois, as alterações políticas e sociais do seu tempo. Juntamente com a antiga aristocracia podem ter desaparecido grande parte dos valores morais tradicionais da classe. Os novos patronos não sentem obrigação moral para com os concidadãos ${ }^{38}$. Neste contexto, Marcial apresenta-se como um poeta pobre, que tem de se submeter a contragosto à situação de cliente para conseguir sobreviver na Urbe. Mas a sua pobreza tem de ser relativizada, perante aqueles que nada têm, excluídos do quadro social: que não são patronos nem clientes, ou que nem sequer são abrangidos pelas distribuições frumentárias. Marcial tinha patronos poderosos; alguns hispânicos como ele. Podia enveredar pela advocacia. É provável que o não tenha feito, porque não terá tido necessidade ou não ambicionava riquezas exageradas.

O poeta valoriza o acto de dar e, além de muitos epigramas sobre ofertas, publica dois livros para acompanhar as dádivas dos jantares e das Saturnais: Xenia e Apophoreta. Mas, acima dos bens materiais, valoriza o apreço pela sua obra (7.88). Assume-se, pois, como pobre, sed non obscurus nec male notus eques, uma vez que pela sua obra é reconhecido no orbe $(5.13 ; 5.16 ; 5.60)$. A consciência do seu status social e literário emerge quando, ao enumerar as riquezas de Calístrato em comparação com a sua pobreza, conclui: Hoc ego tuque sumus: sed quod sum, non potes esse; / tu quod es e populo quilibet esse potest

\footnotetext{
${ }^{36}$ Cf. Juvenal 1.24-25.

${ }^{37}$ E porque apresenta tantas deformidades é que Roma atrai um poeta epigramático. Vide Castagnoli 1950 67-78.

${ }^{38}$ Vide Robert 2004a 48-68.
} 
(5.13.9-10) («Isto somos eu e tu; mas o que eu sou, tu não podes ser; / o que tu és, qualquer plebeu o pode ser») - o que conta é o estatuto social; as riquezas são triviais ${ }^{39}$.

\subsection{O belo e o horrendo}

Outra tensão que existe nos versos de Marcial é entre o belo e o horrendo; o meio-termo, o comum não atrai tanto um poeta epigramático. Em muitos dos casos é difícil separar o eidos do ethos, uma vez que o belo tendia a ser identificado com o bom, bem como o disforme com o mau. O belo é o que está no devido sítio, que cumpre harmoniosamente a sua função, é suave, agradável aos olhos e tem odor agradável; o horrendo subverte a ordem estabelecida, ofende a vista ou os ouvidos e fede. Não espanta que o poeta transmita impressões de prazer ou de desagrado no que toca a sensações gustativas, olfactivas, visuais, auditivas e tácteis.

A mistura do bom e do mau gera efeito cómico, um manancial para o epigrama. Em ambiente de banquete, a falta de gosto de alguns ricos fere a sensibilidade de Marcial. Há vinhos bons e maus, mas misturar o celebrado falerno com vaticano é um crime $(1.18 ; 6.92)$. Aniano bebe esta zurrapa em uma pátera que é uma obra de arte ${ }^{40}$, contradição sinestésica, em que o belo não é acompanhado de bom sabor; e Basso bebe por um copo de vidro, enquanto defeca num bacio de ouro (1.37), um contraste entre a nobreza da matéria e o uso que lhe é dado. Outra falta de sentido estético era esconder a matéria valiosa. Olo apresenta boas mesas, mas cobertas com toalhas (certamente para as não estragar): assim até o poeta pode apresentar mesas excelentes (10.54). No que se refere à roupa, Cina inverte as coisas: a toga, que deveria ser nívea, usa-a sórdida, e o calçado é mais branco do que a neve (7.33). Trata-se pois de desordem, inversão do mundo.

Desordem são também os excessos na comida ou na bebida. O poeta, contrário a excessos $(1.26 ; 12.27)$, reage contra os ébrios inveterados. Um topos muito frequente é o hábito de beber merum, vinho puro, sem a habitual mistura com água $(1.11 ; 6.89)$. Os sintomas da dependência do álcool são a ruína da saúde (6.78), o hábito de beber de manhã (1.28) e palavras inconsequentes: Polião quando bebe à noite promete tudo, mas, pela manhã, não cumpre nada, pelo que o conselho do poeta é que beba de manhã (12.12). A atitude contrária - a de levar a sério as palavras de quem está ébrio - também é objecto de gracejo: Procilo bebeu uma dezena de copos, mas não se esqueceu de que o poeta o convidou para jantar, no dia seguinte. «Não gosto de companheiros de bebida com boa memória!»— diz o poeta em grego (1.27). E, como não podia

\footnotetext{
${ }^{39}$ Vide Mouritsen 2011112.

${ }^{40}$ 6.92; cf. 10.49: Cota oferece a Marcial vinho mau em copo de ouro.
} 
deixar de ser, está presente o topos das beberronas, frequente na comédia (por ex. $1.87 ; 2.73 ; 12.65)$.

O poeta aprecia a ordem. Tudo deve estar no seu lugar. A beleza é feminina; um homem que cultiva a beleza não é bem visto à luz da austeridade tradicional; revela um carácter efeminado ${ }^{41}$. Às suas características de hispano hirsuto, Marcial opõe as de um efeminado de Corinto que ostenta uma cabeleira ondulante e luzidia, à força de unguentos e perfumes, que se depila diariamente e tem uma fala débil (10.65). Critica os depilados (2.36; 3.74; 8.47; 12.38), aqueles que tingem os cabelos (4.36) e os perfumados (7.41); e diz que, em vez de cheirar bem, prefere não cheirar a nada (6.55.5); ou, dirigindo-se a Póstumo, ajuíza que quem sempre bem cheira não lhe cheira bem (2.12). Trata-se de uma abordagem moral. Por um lado, a antiga (e vã) condenação da luxuria ${ }^{42}$, neste caso, no contexto da Roma pós-neroniana: eram bem conhecidos os ditos de espírito de Vespasiano sobre o uso de perfumes ${ }^{43}$. Mas, acima de tudo, o uso de unguentos é interpretado como uma tentativa de camuflar vícios de carácter, isto é, mascarar o hálito resultante de depravação sexual $(11.30 ; 12.85)$. Em causa está a suspeita de cunnilingus ou fellatio, práticas que Marcial considera indignas de um cidadão livre ${ }^{44}$. $\mathrm{O}$ mau hálito pode ser também sinal de abuso do álcool (1.28).

A situação é agravada quando se trata de beijoqueiros. O referido Póstumo representa este grupo ${ }^{45}$. A troca de beijos entre amigos torna-se prática habitual no início da época imperial ${ }^{46}$, além de ser uma forma de uma pessoa mais poderosa mostrar favor para com a mais humilde. Os beijoqueiros são implacáveis perseguidores que o poeta procura evitar por causa do mau hálito ou de doenças contagiosas $(7.95 ; 11.95 ; 11.98$ 12.59). A hipérbole é usada com efeito cómico: a intensidade do mau hálito chega a conspurcar a comida ou bebida ${ }^{47}$ ou até os perfumes (7.94). Há um nítido contraste com os aromáticos beijos de Diadúmeno (3.65; cf. 11.18) ${ }^{48}$, ou o hálito rescendente de Erócion (5.37): nestes casos o belo equivale ao melhor dos perfumes.

Nesta tipologia, entram também mulheres malcheirosas. Certas fulanas, como Bassa e Taís, recorrem a estratagemas para disfarçar os odores corporais

\footnotetext{
(3.63).

${ }^{42}$ Cf. Plínio, Nat. 13.20.

${ }^{43}$ Vide Suetónio, Ves 8.2.

${ }^{44}$ Parece, no entanto, não só tolerar, como até aconselhar a irrumatio, segundo o preconceito de que cura a impotência $(4.17 ; 11.46)$. A irrumatio tem uma função punitiva de prevaricadores.

${ }^{45} 2.10 ; 2.21 ; 2.22 ; 2.23$.

${ }^{46}$ Cf. Séneca, Dial. 4.24.1; 8.44.4-5; 12.29.4.

${ }^{47}$ Cf.2.15: Hormo, consciente do seu defeito, é por caridade que evita beber à saúde de alguém; 3.17: depois que Sabídio soprou sobre uma tarte quente, nemo potuit tangere: merda fuit.

${ }^{48}$ Vide Sullivan 1991 232-234.
}

${ }^{41}$ Sed qui bellus homo est, Cotta, pusillus homo est (1.9.2); Res pertricosa est, Cotile, bellus homo 
(3.55; 4.4; 4.87; 6.93) ou o cheiro do vinho (1.87). Mas, em vez do uso de máscaras, o poeta prefere a autenticidade (simplicitas) (1.Praef.; 1.87.8; 3.42.3; $6.7 .6 ; 10.83 .9)$. Na mudança de casa de Vacerra o leitor consegue sentir o cheiro a ranço e a peixe estragado que ressuma dos trastes (12.32).

No que toca à exploração do visual, o poeta mostra uma complacência por vezes cruel em identificar traços disformes. Os defeitos físicos eram temas comuns no humor antigo, tal como eram alvo da atenção da biografia. Os uitia corporis podiam espelhar vícios da alma, e as teorias fisiognomónicas procuravam estabelecer relação entre aparência física e traços de carácter ${ }^{49}$ : por exemplo, ter um aspecto pálido pode ser sinal de perversão sexual (1.77). Marcial não hesita em caricaturar a fealdade: parece ironia chamar Febo (isto é, um Apolo) a um fulano que tem as pernas em meia-lua (2.35) e apresenta uma cara contraída de quem está na casa de banho (3.89) ${ }^{50}$; Sexto vangloria-se de que as moças ardem por ele, mas o seu rosto lembra o de um nadador debaixo de água (2.87), pelo que se deduz que apaga tal fogo. Há os sexualmente bem dotados (6.36), os impotentes $(2.45,3.70 ; 3.73 ; 3.75)$, os desdentados (6.74; 8.57), os carecas $(5.49 ; 10.83 ; 12.45 ; 12.89)$, os narigudos - e ter um grande nariz significa grande propensão para a crítica (12.88). O poeta Júlio Rufo, no frontispício das suas Sátiras, parece-se com o conhecido e grotesco rosto de Sócrates (10.99).

Da mesma forma, encontramos mulheres repelentes, como Maneia (1.83) a quem só um cão pode beijar, seja qual for o significado que se queira dar aos os et labra ${ }^{51}$, ou Filene, de quem o poeta evita o beijo $(2.33 ; 10.22)^{52}$; feias por natureza (5.29), ou por degradação do corpo: calvas $(6.12 ; 12.7)$, desdentadas $(1.19 ; 5.43)$, zarolhas $(2.33 ; 3.8)$. Outro grupo são as velhas gaiteiras que não assumem a idade $(1.100 ; 3.32 ; 8.79 ; 10.39)$ ou pretendem casar-se $(3.93 ; 3.32)$. $\mathrm{O}$ ataque às mulheres idosas é um topos da comédia antiga grega, frequente no epigrama (especialmente na Grinalda de Filipe) e bem representado por Canídia, nome sugestivo da sátira de Horácio (1.8). Brincadeiras sobre a falta de dentes, de cabelo, de um olho ou outras deformidades representam para nós mau gosto, mas devem ter sido muito apreciadas na antiguidade ${ }^{53}$. Ainda assim, há aqueles a quem só agradam velhas decrépitas (3.76). São numerosos os epigramas que versam sobre as mulheres e sobre os vícios mais conotados

\footnotetext{
${ }^{49}$ Vide Sullivan 1991168.

${ }^{50}$ Semelhante anedota corria acerca da face do bem-humorado Vespasiano, imperador de 69 a 79 d.C. Cf. Suetónio, Ves. 20

${ }^{51}$ Com efeito há quem veja neste epigrama a referência a mau hálito decorrente da prática da fellatio ou a o uso do cão para cunnilingus. Vide Howell 1980287.

${ }^{52}$ É negro o retrato que Marcial nos apresenta de Filene (cf. 4.65; 7.67, 7.70; 9.40; 12.22). O poeta parece inspirar-se no nome da poetisa Filene de Samos, subvertendo os seus ensinamentos sobre a arte da sedução: cf. Burzacchini 1977 239-243.

${ }^{53}$ Vide Howell 200974.
} 
com o seu sexo. Nem sempre a beleza corresponde à bondade: o poeta aproveita humoristicamente o efeito da contradição entre beleza e falta de castidade (8.54); e entre beleza e riqueza, por um lado, e falta de modéstia, por outro, quando se alardeiam tais qualidades (1.64).

A intervenção do poeta tem naturalmente em conta a virtudes do mos maiorum e os vícios opostos. Espelha nomeadamente a transformação da família em Roma e a moral imperial a esse respeito. Domiciano procurou restaurar a lex Iulia de adulteriis coercendis, promulgada por Augusto, que castigava os adultérios, mas certas mulheres, contornando a lei, casam com os sucessivos amantes (6.7 e 6.22). Para o poeta, uma madrasta que permanece em casa do enteado depois da morte do pai, nunca foi madrasta (4.16), situação mais grave porque implica adultério e incesto. $\mathrm{O}$ incesto jamais foi admitido pela sociedade romana e estendia-se às relações parentais procedentes da adopção. O caso mais famoso é talvez o do imperador Cláudio que necessitou de uma dispensa especial do senado para casar com a sobrinha Agripina, união que na época era considerada incestuosa. $\mathrm{O}$ incesto estava associado aos tiranos - talvez através da tragédia e dos costumes de reinos orientais. A tradição histórico-biográfica regista anedotas de incesto entre Calígula e as irmãs, especialmente Drusila, entre Nero e a mãe Agripina, e entre Domiciano e a sobrinha Júlia, mas provavelmente essa seria uma forma de os associar a típicos tiranos.

No que toca a homossexualidade, Marcial condena a relação entre senhor e escravos quando o homem livre assume uma atitude passiva (cf. 3.71), porque tal implica uma subversão de papéis sociais ${ }^{54}$. Os banhos são um local privilegiado para devassos e voyeurs e para o engate $(1.23 ; 1.96 .12 \mathrm{ss}$; $9.33 ; 11.63)$. E havia banhos mistos $(3.51 ; 3.72 ; 11.63)$, mais tarde abolidos por Adriano. $\mathrm{Na}$ censura da desordem, ao poeta não passou despercebido um matrimónio homessexual, segundo os ritos habituais de um casamento romano ${ }^{55}$, inspirado possivelmente nos boatos que corriam sobre estranhos rituais de Nero com o eunuco Esporo ${ }^{56}$. E quanto à ideia de que as orgias eram apreciadas como forma de entretenimento pelos romanos, não há evidência de que assim seja ${ }^{57}$. Marcial desaprova (12.43).

O vocabulário do poeta é amiúde congruente com os vícios que pretende censurar. Trata-se da dicacitas, a linguagem acirrada, própria dos versos fesceninos,

${ }^{54}$ Vide Garrido-Hory 1981 300-306.

55 12.42. Em 1.24, apresenta-se um fulano de aspecto austero que nupsit-isto é, casou no papel de esposa.

${ }^{56}$ Cf. Suetónio, Nero 29.

${ }^{57}$ Cenas eróticas representadas num apodyterium de banhos de Pompeios, parecem ser um expediente cómico para os utilizadores memorizarem o cacifo das roupas. Vide Howell 2009 $86-87$. 
que se aplica a zurzir os defeitos físicos e morais, por vezes visível nos cognomes. Está presente nos grafitos e nos libelli de epigramas, bem como nos versos que os soldados cantam nos triunfos de César (Suet. Jul. 49.4; 51). A obscenidade satírica provoca uma espécie de exclusão, de algum modo semelhante ao que acontece no sacrifício do bode expiatório. Os insultos mais violentos que o poeta usa são irrumo e paedico. Em qualquer dos casos trata-se de penetrar/violentar o visado, mas irrumare é o mais infamante porque condena o visado ao silêncio. Ora a obscenidade do poeta tem o mesmo papel castigador da irrumatio ${ }^{58}$. Mas o poeta salienta que esta linguagem tem um contexto próprio e um objectivo apotropaico: o dos Jogos Florais, associados ao culto da fertilidade (1.Praef.; 1.35.8), e o das Saturnais (11.2; 11.15), onde a licenciosidade era admitida. Mas procura evitá-la quando se trata de adular o imperador (8. Praef.).

O poeta é sensível ao que lhe fere os tímpanos. Numa época em que a leitura era feita em alta voz e a poesia era para ser ouvida, nos banquetes, nas termas, ou outros espaços públicos, Marcial, consciente da qualidade dos seus versos e exigente no labor limae, não deixa de criticar os maus poetas e recitadores: os pretensiosos que nada compõem $(4.33 ; 6.14 ; 10.102)$, ou que compõem maus versos $(7.3 ; 5.73 ; 11.93)$; os que, conscientes da fraca qualidade, nem se atrevem a recitar $(2.88 ; 8.20)$; os que recitam plagiando o poeta $(1.52 ; 1.66)$, como faz Fidentino $(1.29 ; 1.53 ; 1.72)$, apesar de recitar mal (1.38). Marcial mostra-se reiteradamente agastado com os que aproveitam todas as oportunidades para massacrar os ouvidos dos presentes $(1.63 ; 2.71$; $3.18 ; 3.44 ; 3.45 ; 3.50 ; 4.41 ; 4.80 ; 6.41)$. Nestes círculos, movem-se também os invejosos. O poeta increpa asperamente os que vêem com maus olhos o seu sucesso literário e social $(8.61 ; 9.97 ; \text { cf. } 4.27 ; 4.77)^{59}$.

A cacofonia da Urbe torna-se cada vez mais odiosa para o poeta, que enumera um por um os ruídos da noite, porque quem não habita numa domus tem Roma à cabeceira (ad cubile est Roma) $(12.57)^{60}$. Em 1.41, a propósito de um fulano que se considera urbanus, Marcial desfia uma longa lista dos vendedores de várias etnias que apregoam a mercadoria pela cidade. A casa de Júlio Marcial no Janículo tem a vantagem de facultar uma vista aprazível sobre a cidade: um quadro em movimento da azáfama urbana ao qual foram retirados os ruídos (4.64.11-25).

O belo está na simplicidade, na ausência de artifício e por isso nas crianças. A beleza está pois em Erócion, escravinha que morreu na infância. Numa

${ }^{58}$ Vide Robert 2004a 48-68.

${ }^{59}$ Vide Torrão 2010 71-101.

${ }^{60} \mathrm{Cf}$. Juvenal 3. O tema caro a Séneca, de que não está só consigo, está presente nos epigramas e condição de cliente desenraizado apresenta-se por referência ao espaço urbano. Há um sentimento de dependência em termos de alienação: cf. 10.58.6-8. Vide Pailler 1981 79-87. 
sinestesia obtida por comparações com os arquétipos de beleza e bom gosto, diz o poeta que a cabeleira da menina triunfa sobre o velo dos rebanhos da Bética, ou a pele dourada de um esquilo; o seu hálito tem a fragrância das rosas de Pesto, dos méis dos favos áticos, de um pedaço de âmbar. Ao pé dela o pavão perde a beleza, a fénix torna-se vulgar (5.37.1ss).

As tomadas de posição do poeta acabam por ser mais interventivas do que parece à primeira vista e estão em continuidade com a tradição e com a moralidade imperial. Ele próprio assume tal função moralizante quando admite que, poupando embora as pessoas, zurze nos vícios (parcere personis, dicere de uitiis) (10.33). Reflecte uma ordem social estabelecida, onde cada qual cumpre o seu papel e não admite subversão; e a promoção deve ser baseada no mérito e acompanhada de elevação de carácter.

\section{A laus Vrbis: topografias da cidade}

No prólogo do livro XII, Marcial refere com saudade os espaços por onde costumava passear (12.21). É a Roma engrandecida pelos Flávios e motivo de adulação por parte do poeta, é o local de actuação dos tipos sociais que vai referindo, são os espaços da vida literária (vendas dos livreiros, percursos dos livros para saudar um patrono) e são os trajectos das deambulações e canseiras do poeta, que descreve as impressões dos meandros urbanos. Roma é o cenário dos epigramas, e, embora deseje o otium fora da Urbe, Marcial vive esta contradição de necessitar do espaço urbano para a sua criação poética. A representação topográfica da Urbe é, pois, uma estratégia literária associada ao género que o nosso poeta cultiva; para mais, num período em que que as estruturas da Urbe sublinham a afirmação do poder de uma nova dinastia. Muitos dos epigramas integram-se no consagrado género da laus urbis ${ }^{61}$.

\subsection{Roma antes e depois}

Augusto dissera que encontrara uma Roma de tijolo e a deixara de mármore. Como outrora Augusto ${ }^{62}$, Vespasiano e os filhos procuraram restaurar e ornamentar moral e fisicamente a cidade depois da sumptuosidade de Nero e das consequências do conflito civil de 68-69 na disciplina e nos edifícios ${ }^{63}$. Fica, por isso, patente a continuidade essencial em relação aos Júlio-Cláudios, apesar de os Flávios se procurarem demarcar do luxo do último representante

${ }^{61}$ Vide Sullivan 1991147 ss; Roman 201099 ss; Coleman 200615.

${ }^{62}$ Cf. Suetónio, Aug. 28.3: Vrbem neque pro maiestate imperii ornatam et inundationibus incendiisque obnoxiam excoluit adeo, ut iure sit gloriatus 'marmoream se relinquere, quam latericiam accepisset'. Tutam uero, quantum prouideri humana ratione potuit, etiam in posterum praestitit.

${ }^{63}$ Suetónio, Ves. 8.1: ac per totum inperii tempus nibil habuit antiquius quam prope affictam nutantemque rem $p$. stabilire primo, deinde et ornare. 
da dinastia. De resto, Tito foi durante algum tempo educado na corte de Cláudio e íntimo de Britânico, filho do imperador.

O Liber Spectaculorum, cuja publicação celebra a inauguração do anfiteatro Flávio em 80 d.C., procura salientar a continuidade em relação a Augusto, apesar da descontinuidade genealógica. Com efeito, Vespasiano justificava a construção como sendo um projecto de Augusto (Suet. Ves. 9.1). O grandioso edifício (começado por Vespasiano, inaugurado por Tito e concluído por Domiciano) perdurará pelos séculos como símbolo dos Flávios, embora o nome pelo qual é vulgarmente conhecido - Coliseu - lembre o colosso de Nero que se erguia no lugar. No epigrama de abertura do livro, Marcial, empregando a estrutura de um poema catálogo, evoca as maravilhas do mundo antigo, para no final $(S p .1 .7-8)$ reclamar a superioridade deste anfiteatro. No epigrama seguinte, estabelece o contraste entre passado e presente através do louvor das construções que se elevaram no lugar da Domus Aurea, a extravagante uilla, construída no centro da Urbe na sequência do incêndio de 64 - um símbolo da arrogância tirânica de Nero que levantou críticas anónimas (Suet. Nero 39.2). O poeta, dando voz à propaganda flaviana, clama que reddita Roma sibi est («Roma foi restituída a si mesma») (Sp. 2.11). A oposição entre passado e presente corresponde à metamorfose de espaço fechado em espaços abertos de deslocação, de convívio e de espectáculo; à transformação dos deleites do tirano (dominus) em deleites do populus (Sp. 2.12) ${ }^{64}$.

A ideologia que está por trás do engrandecimento da Urbeé a de que a cidade é expressão da maiestas do povo romano, com um propósito propagandístico tanto para o interior como para o exterior. Se a Domus Aurea de Nero era como um microcosmo do império em volta do lago central - ideia que parece emanar da descrição feita por Suetónio ${ }^{65}$-, o novo Anfiteatro abre os braços também aos povos de terras distantes. $O$ terceiro epigrama do livro apresenta o Coliseu, o cenário implícito, como espaço de cosmopolitismo e sinal visível da vocação multicultural e multiétnica de Roma. A passagem da diversidade à unidade opera-se sob a égide do imperador: a presença de falantes das mais

${ }^{64}$ Vide Pailler 1981 79-87; Roman 2010111.

${ }^{65}$ Nero 31.1-2: «(...) Sobre a extensão e aparato será suficiente mencionar o seguinte: era tal o vestíbulo que nele se erguia um colosso de cento e vinte pés com os traços do dono; eram tão grandes as áreas, que continham um triplo pórtico de uma milha; e também um lago à imitação de um mar, rodeado de construções a fingir de cidades; e, ainda por cima, diversos campos, de cultivo e de vinhas, de pastagens e florestas, com uma vasta fauna de todo o tipo, de gado doméstico e animais selvagens. Nas restantes partes, tudo estava recoberto de ouro e adornado de gemas e de conchas de pérolas. As salas de jantar tinham os tectos artesoados com placas de marfim móveis, de modo a espalhar flores do alto, e perfuradas, para lançar borrifos de perfumes. A sala de jantar principal era arredondada, para poder rodar continuamente, dia e noite, a fazer as vezes de mundo. Nos banhos corria água do mar e de Álbula. Concluída deste jeito a moradia, ao inaugurá-la, deu a sua aprovação, limitando-se a dizer que finalmente começava a habitar que nem um homem!» 
diversas línguas, que se unem para aclamarem a uma só voz Tito como Pai da Pátria, celebra o carácter englobante do imperium, exercido pelo princeps, e da língua latina ( $S p .3 .12$ ). Fica claramente expresso o papel unificador do princeps, virtude que se expressa ao mundo através da arquitectura e da língua. E a mais sublime expressão da língua é a literatura, de que Marcial é um dos cultores.

A imagem da Fénix é associada a Roma, que por obra de Domiciano renasce das cinzas, provavelmente depois do incêndio de 80 d.C. (5.7). O contraste entre passado e presente é representado na distinção entre a magna taberna que antes era e a Roma que agora é. Trata-se do elogio da política urbana de Domiciano, que disciplinou os proprietários das barracas e desimpediu as ruas: assim o poeta pode dizer que o imperador fez reaparecer Roma onde antes existia como que uma contínua tenda de vendedores (7.61).

Uma imagem de Domiciano restaurador e construtor de templos é passada de forma espirituosa em 9.3: ao colocar o imperador como credor do pai dos deuses, Marcial sublinha o aspecto religioso da política de construções. Também neste aspecto Domiciano é apresentado em continuidade com Augusto. Representa o retorno da antiga religião à herança augustana (8.80). O Templo dos Flávios reforça a ideia da consolidação da dinastia (9.1. 9.3; 9.20; 9.34): fazendo eco à ode 3.30 de Horácio, Marcial vaticina a eternidade deste santuário (9.1.5-5), que é também o mausoléu da família ${ }^{66}$. Destaca assim a conexão existente entre arquitectura e religião na expressão do imperium Romanum.

A obra de Domiciano é glorificada ainda através do elogio do arquitecto Rabírio, autor do palácio no Palatino (7.56). O edifício, designado também por ueneranda Palatia (1.70.5), e comparado em outro passo com as pirâmides do Egipto (8.36), era gigantesco; e junto a ele foi construído o santuário de Minerva, divindade que o imperador venerava com especial fervor. Marcial é, portanto, a expressão da ligação entre a arquitectura e a literatura na prossecução de um mesmo fim: ser a ponte eloquente entre o poder do imperador e o "orbe" que ele governa.

\subsection{Itinerários da Urbe: das personagens, do poeta, dos livros}

Marcial refere-se diversas vezes a percursos da cidade feitos pelas personagens dos epigramas, por si próprio ou pelo livro que envia como seu embaixador. Evidencia-se desde logo o roteiro de Sélio, que circula na ânsia de conseguir um convite para jantar (2.14). O cenário é o Campo de Marte, local onde a sociedade romana era vista nos banhos, nos teatros, nos pórticos, nos templos. A ansiedade e frustração do parasita são expressas pelo facto de

${ }^{66}$ Vide Roman 2010113. 
andar em círculo, visitando repetidamente os mesmos lugares. Marcial nomeia os espaços, demonstrando implicitamente que Sélio fica confinado a locais topograficamente próximos, num percurso que não leva a lado nenhum: começa por um provável pórtico com uma representação do rapto de Europa, que alguns fazem coincidir com o Pórtico de Vipsânia, construído pela irmã de Agripa; dirige-se depois aos Saepta Iulia, o local das eleições, onde depara com um grupo escultórico do centauro Quíron, filho da Oceânide Fílira, a ensinar Aquíles ${ }^{67}$ e uma representação de Jasão, filho de Éson (possivelmente uma pintura do Pórtico dos Argonautas, mencionado em 3.20 e 11.1, que ladearia os Saepta a oeste); avança para o templo de Ísis e Serápis, frequentado sobretudo por mulheres, depois para o Hecatóstilo (o pórtico das cem colunas); depois para o Pórtico de Pompeio, junto do teatro do mesmo nome; frequenta até as termas de Lupo e de Grilo, as de pior qualidade; repete o banho nas mais bem cotadas, de Agripa, de Nero e de Tito; e, sem conseguir o esperado convite, volta no final ao ponto de partida. O leitor contemporâneo de Marcial consegue vislumbrar imediatamente o trajecto, mas, em vez de dar indicações objectivas, o poeta preenche o poema com erudição histórica ou mitológica ligada aos lugares frequentados, por meio da qual, mais do que descrever, evoca as sensações do leitor conhecedor dos espaços e estimula a sua imaginação. O epigrama apresenta uma pintura plausível de uma tarde de actividade no Campo de Marte, onde se poderiam encontrar frequentadores, como Ático, que por ali costumava correr $(7.32 .11-12)^{68}$.

Outro itinerário destacado é o que faz o poeta até aos seus protectores. Marcial queixa-se várias vezes da distância que tem de percorrer para saudar um patrono ou ir visitar um amigo, para mais correndo o risco de ele estar ausente ou ocupado $(1.70 ; 1.108 ; 2.5 ; 5.22 ; 10.56 ; 10.82)$. Um ponto de referência na relação entre o poeta e o espaço da Urbe é, pois, o lugar onde o poeta habita, no Quirinal (1.117; cf. 1.108). Em 5.22 descreve o caminho que tem de fazer desde a sua morada até ao Esquilino, passando pela Suburra, para saudar um patrono, designado pelo nome de Paulus. Também Plínio o Moço habita nesta zona, mas, como o poeta envia simbolicamente a Musa (Talia) como portadora do livro, já constata que afinal nem é grande o esforço (10.20.4-5).

A relação entre o autor e os espaços da Urbe opera-se também através do livro, usado muitas vezes como metonímia do poeta. O motivo ovidiano de enviar o livro do exílio ${ }^{69}$ é transferido por Marcial para o contexto das obrigações de cliente, como forma de evitar a perda de tempo de ir pessoalmente cumprir a salutatio (cf. 1.108). Encontra assim pretexto para introduzir passo a passo

\footnotetext{
${ }^{67}$ Cf. Plínio Nat. 36.29.

${ }^{68}$ Vide Sullivan 1991 151-153; Prior 1996 121-141; Williams 2004 67-75.

${ }^{69}$ Cf. Ovídio Trist. 1.1; 3.7; Pont. 4.5.
} 
alusões arquitectónicas na descrição de um percurso. É o caso do trajecto do livro em direç̧ão à casa do amigo Próculo (1.70), um poema que, pelo local e pelas referências, recorda também o ibam forte Via Sacra de Horácio (Sat. 1.9). Trata-se de uma significativa subida desde o Forum, centro de Roma, até ao Palatino, com menção dos locais que se vão encontrando: os templos de Castor e de Vesta, o palácio de Domiciano, com uma enorme imagem em ouro, o templo de Baco e o de Cíbele com um coribante pintado, deixando à esquerda a visão do colosso com os seus raios. Embora se dirija ao patrono, na mente do poeta parece estar o imperador. Comparativamente com o trajecto chão e circular do parasita Sélio, a ascensão do livro ao Palatino sugere as ambições sociais e literárias do poeta. O livro que Marcial envia a Plínio (10.20) faz uma ascensão semelhante, desde o meio da Suburra até ao alto de Esquilino, com diversas indicações topográficas ${ }^{70}$. O livro funciona assim como uma espécie de câmara fotográfica dos nossos dias que regista pontos seleccionados: é o viajante através dos espaços e ao mesmo tempo o repositório imortal dos locais que atravessa.

Tal como o autor, os livros têm a sua morada. Neste caso, os percursos descritos são no sentido de levar os leitores até ao lugar dos epigramas. Marcial dá indicação sobre o nome dos livreiros e os locais onde se podem encontrar as obras à venda (1.2;1.117; 4.72).1.117 (assim como 4.72) constitui uma resposta humorística a um pedido descarado de um livro - Marcial, com a desculpa de que mora longe, aponta o Argileto, em frente ao Foro de César, a rua onde abundavam as vendas de livros $(1.2 .8 ; 3.1)$, uma informação aparentemente desnecessária (e por isso trocista), pois que seria do conhecimento de qualquer habitante de Roma.

Em suma, são referidas as diversas áreas da Urbe, as vias, os fora, estátuas, templos, pórticos, anfiteatros, teatros, circo, termas, elementos importantes na vida social romana, pois são locais de vida cívica e religiosa, bem como de entretenimento e convívio. Encontramos nos epigramas grande número edifícios públicos e privados. Há a Roma dos ricos e dos pobres. Em 1. 62, Marcial faz o contraste entre os banhos de luxo de Baias, onde há águas termais, e os de Roma. Louva os banhos luxuosos de Cláudio Etrusco, seu patrono (6.42). Faz, por exemplo, a ekphrasis de uma sala de jantar, designada por Mica (2.59), cuja localização tem sido alvo de estudo. São contribuições preciosas para a pesquisa da topografia de Roma antiga, com indicação de direcções $(2.14 ; 3.20 ; 7.32 ; 11.1)$, em que figuram mesmo os únicos testemunhos de um retrato de Europa ${ }^{71}$.

A Roma descrita reflecte a vida e profissão de Marcial; e os epigramas "representam" Roma. Nestes itinerários, a criação literária recorre a relações

\footnotetext{
${ }^{70}$ Vide Roman 2010 103-105.

${ }^{71}$ Vide Castagnoli 1950 67-78.
} 
intertextuais e interpoéticas, pela intersecção com a arquitectura, pintura, vida cultural e social. A reforçar a intenção de glorificar está a consciência de que os versos são imortais à maneira horaciana.

\section{Poética de exílios}

A atitude de Marcial para com Roma é contraditória: por um lado, Roma é barulhenta e fatigante e monótona $(10.58 ; 2.5)$, por outro é bela e grandiosa. Além disso, o poeta concebe um ideal de vida simples, longe do bulício e dos afazeres da cidade, onde tenha tempo para se dedicar ao ócio produtivo e aos amigos e onde possa retirar da terra o sustento de uma mesa não artificiosa. Mas, por outro lado, precisa da Urbe e da sua vida social como fonte de inspiração. É da Urbe que vivem os epigramas. Na Urbe, o poeta está como que exilado do seu ideal de vida, mesclado de nostalgia da pátria hispânica. Fora da Urbe está exilado do mundo dos epigramas.

\subsection{Vita urbana e uita rustica}

O topos helenístico do contraste entre vida do campo e vida da cidade está continuamente presente. Em 1.55, o poeta expõe princípios de vida em colisão com a vida na Urbe: por um lado, a rejeição das obrigações sociais que a vida de cliente impunha, simbolizadas pela «frieza colorida do mármore espartano» dos átrios dos poderosos e pela saudação matinal (matutinum haue); por outro, o desejo epicurista de uma vida simples e frugal num campo que pudesse cultivar e donde extraísse o necessário à sua subsistência.

Confessa-se, pois, saturado por ter de suportar tal vida durante três décadas (3.36). Por altura da publicação do livro $X$, o poeta parece atingir a exaustão: cansado (ruptus) de deambular pela Urbe (10.56), farto de suportar o frio e a neve ${ }^{72}$, a única coisa que deseja é dormir (10.74). O topos da dificuldade em escrever em Roma, que já vem de Horácio (Ep. 2.65ss), é transposto para o prejuízo que as obrigações de cliente acarretam para produção literária (1.70;10.70; 11.24). O patrocínio não era já o mesmo do tempo de Virgílio e de Horácio, e Marcial queixa-se de não ter um mecenas que lhe faculte o otium de que aqueles poetas gozaram (1.107.3-4); e a generosidade dos patronos tende a diminuir (12.36).

Além disso, a cidade é um labirinto insalubre: as ruas são estreitas e sinuosas (1.86.1-2) ${ }^{73}$, o ambiente é doentio ao ponto de tornar o rosto descorado (10.12.8-12), há cheiros nauseabundos (6.64.18-21), há ruídos dos pregões de

72 10.82. note-se que a primeira edição deste livro é do ano 95, mas a segunda, revista (segundo 10.2.3), é de 98, ano do retorno a Bílbilis. Vide Sullivan 199144.

${ }^{73}$ Vide Torrão \& Andrade 2008 63-79. 
vendedores (1.41), há a azáfama nocturna $(12.57)^{74}$. Por isso, louva a casa que o amigo Júlio Marcial possui no Janículo, de onde se pode apreciar a cidade sem lhe ouvir os ruídos (4.64). Com a chegada do Verão, a alta sociedade romana procura as águas de Baias para uns tempos de descanso e devaneio $(1.62 ; 3.20 .19 ; 3.58 .1 ; 10.14 .3)$. O poeta, que se assume como preguiçoso, quer afastar-se da cidade, mas não ficar muito longe dela. A celebrada propriedade de Nomento, cerca de $20 \mathrm{~km}$ a noroeste de Roma, cumpre os requisitos. Aí procura o otium, na sua casa de campo, que substitui as delícias de Baias (6.43.5-6). Para lá se dirige o poeta em busca da libertação da vida citadina e do sono tranquilo $(2.38 ; 12.57)$. O poeta aprecia o sossego, longe da confusão dos locais que estão na moda. De resto, ao sol abrasador das praias da Campânia diz preferir a frescura de Tíbur (4.57) e as praias de Altino, rivais de Baias, na Gália Cisalpina (4.25).

A vida feliz que propõe não inclui desejos de riquezas (9.22.16), mas uma diária simples com noites tranquilas e dias sem disputas (2.90.7-10). Prestes a rumar à Hispânia, o poeta propõe ao amigo Júlio Marcial um estilo de vida mais feliz (uita beatior) que é uma típica versão romana da filosofia epicurista $(10.47)^{75}$ : a toga rara representa o almejado afastamento da vida pública, um princípio epicurista, porque a toga é símbolo da vida social romana, do foro e da clientela, o contrário da quietude de espírito (mens quieta). Acrescenta-se a saúde do corpo, a simplicidade de vida, a amizade desafectada, o convívio simples sem artifícios em vez de banquetes requintados, moderação na bebida, noites sem preocupações, moderação nos prazeres, sono descansado - uma aurea mediocritas, em que cada um se contenta com o que é, sem desejar ser outra coisa, de modo a não temer nem desejar a morte.

Perante a consciência da fugacidade da vida, Marcial, em 1.15, advertira o amigo de que estava a desperdiçar os melhores dias ${ }^{76}$. O tema do carpe diem surge ligado à partilha da amizade em despreocupados passeios pelos espaços da Urbe (5.20, cf. 11.80): o Campo de Marte, pórticos, aqueduto da Água Virgem, as termas. Mas Júlio Marcial seria também um cliente e talvez exercesse a profissão de advogado. Como impedimento para o tempus otiosum, surgem sempre os atria e as domus potentum, as lites tetricae et forumque triste, as imagines superbae. Quando Marcial envia o livro em vez de ir ele próprio, está, através da intertextualidade com Ovídio, a assumir-se como um exilado

${ }^{74}$ Vide Augello 1968-69 242-244.

${ }^{75}$ Cf. Horácio, Epodo 2. Sobre o paralelismo entre o epigrama acima transcrito e a filosofia epicurista, vide Sullivan 1991 215-217; Adamik 197562.

${ }^{76}$ bis iam paene tibi consul tricensimus instat, / et numerat paucos uix tua uita dies. (...) et solum hoc ducas, quod fuit, esse tuum. (...)gaudia non remanent, sed fugitiua uolant. (...) Non est, crede mibi, sapientis dicere 'uiuam': / sera nimis uita est crastina: uiue hodie. Outros exemplos de sentenças de espírito epicurista em Sullivan 1991225. 
da verdadeira vida (a uita beatior) que gostaria de fruir na companhia dos amigos.

\subsection{Bílbilis: reencontro e desencontro}

No que toca à oposição entre cidade e campo, Marcial, seguindo embora o modelo de Horácio (Ep. 2. 65-80; Sat. 2.6), cruza o topos com a saudade da terra natal, Bílbilis, na Hispânia (1.49), de que descreve os montes, os rios, os campos. Perante as crescentes dificuldades políticas, sociais e económicas da vida em Roma, a saudade e a poesia juntam-se para the apontarem agora novo rumo $(10.96)^{77}$ : a sede do aurífero Tago e do pátrio Salão coincide com a procura de um local onde os recursos da terra sejam suficientes para a sobrevivência. A partida para Bílbilis torna-se iminente. $O$ poeta prepara o seu regresso na expectativa de um bom acolhimento por parte dos seus patrícios. Aos municipes da Augusta Bilbilis dirige um epigrama em que apela à própria fama: Verona não deve mais a Catulo do que Bíbilis ao seu vate encanecido em terras itálicas (10.103). Em 10.104, pede mais uma vez ao livro, o garante da sua fama, que vá à frente a preparar-lhe o regresso.

Já em Bílbilis, o poeta confessa que está a fruir do modo de vida e da liberdade que tanto desejara. No livro XII, um longo epigrama dirigido a Juvenal, Marcial estabelece o contraste entre a vida de cliente, que o amigo continua a suportar em Roma, e a sua própria vida de camponês liberto de cuidados em Bílbilis, onde já pode dormir quanto quer $(12.18)^{78}$. Este modo de vida deve-o o poeta à generosidade de Marcela, uma mulher cuja cultura poderia rivalizar com a de uma matrona de Roma (12.21), como se disse.

Mas, uma vez em Bílbilis, sente a falta dos argumentos que Roma lhe oferecia como estímulo para a criação dos epigramas: (...) illam iudiciorum subtilitatem, illud materiarum ingenium, bibliothecas, theatra, conuictus, in quibus studere se uoluptates non sentiunt, ad summam omnium illa quae delicati reliquimus desideramus, quasi destituti («aquela argúcia dos juízos, aquela fecundidade dos argumentos, as bibliotecas, os teatros, as reuniões, onde se estuda sem que o prazer se ressinta - em suma, tudo aquilo que, por despeito, abandonei e de que agora sinto a falta, a modos que defraudado»).

A reforçar a saudade de Roma conta-se certamente a recordação dos velhos amigos que deixara. Os locais de que diz sentir agora a falta correspondem grosso modo aos lugares onde gostaria de gozar o ócio na companhia de Júlio

\footnotetext{
${ }^{77}$ Cf. Sullivan 1991 44-52.
}

${ }^{78}$ Segundo Frassinetti 1973 173-180, Marcial ostenta, neste epigrama, um falso entusiasmo: trata-se já do desfazer do sonho de paz. Seja como for, o certo é que o poeta descreve agora como real aquilo que em Roma era apenas um sonho. 
Marcial (5.20.8-10) ${ }^{79}$. Do balanço dos trinta e quatro anos que conviveu com o amigo em Roma conclui que o resultado é claramente positivo (12.34).

O fluir do tempo está bastante presente nos epigramas com as consequentes marcas de mudança ${ }^{80}$ : mudou a política, mudou Roma, mudou o poeta, mudaram os amigos e mudou a relação do poeta com Bílbilis. Se exceptuarmos os casos de Marcela e de Prisco, Marcial não parece ter encontrado o acolhimento caloroso que esperava da parte dos conterrâneos. Pelo contrário, encontra a maledicência e inveja de alguns, que se tornam muitos num meio pequeno ${ }^{81}$. Além disso, alguns oportunistas locais procuram aproveitar, em benefício próprio, a posição social que a fama conferiu ao poeta. Marcial constata que, mesmo aqui, na Hispânia, lhe querem negar aquilo que Roma lhe proibia: o ócio, o sono e a ausência de litígios; e propõe-se voltar para a Urbe se também aqui não o deixam dormir (12.68). Mas o tempo escasseia; a morte está próxima.

Ao anterior itinerário centrífugo do livro, que sai de Roma para as províncias, opõe agora o poeta um percurso centrípeto. A reversão do sentido representa a orientação tomada pelo espírito do poeta, que se sente, como Ovídio ${ }^{82}$, privado de Roma: ad populos mitti qui nuper ab Vrbe solebas / Ibis, io, Romam nunc peregrine liber («Ainda há pouco costumavas partir da Urbe, às gentes enviado; / eis que agora irás para Roma como livro forasteiro») (12.2). O poeta visualiza a morada do amigo Estela com as habituais indicações precisas. E o envio do livro é acompanhado da consciência de que será imediatamente identificado e apreciado porque é irmão dos outros produzidos na Urbe. Se Roma é o centro irradiador de cultura, é também aí que o livro produzido na província vai buscar a autoridade, o selo de qualidade que lhe garantirá o sucesso e a imortalidade.

Com efeito, o livro XII, embora composto em Bílbilis, está cheio de reminiscências que o poeta guardou da Urbe: os habituais temas satíricos como a hipocrisia dos patronos, a decadência do rico, a captatio, as pretensões dos clientes, a má conduta social, a pederastia, a crítica às mulheres, os defeitos físicos, a poesia e os críticos, os plagiários, enfim, um livro não de assunto hispânico, mas apenas escrito na Hispânia ${ }^{83}$. Deste modo, o livro XII contém ao mesmo tempo o grito de libertação da opressão da Urbe, pelo retorno a casa,

\footnotetext{
${ }^{79}$ Sed gestatio, fabulae, libelli, / campus, porticus, umbra, Virgo, thermae.

${ }^{80}$ Para uma análise detalhada do fluir do tempo em Marcial vide Pimentel 2000 221-230.

${ }^{81}$ Cf. 12. Pref. (...) Accedit his municipalium robigo dentium et iudici loco liuor et unus aut alter mali, in pusillo loco multi.

${ }^{82} \mathrm{~A}$ intertextualidade de 12.2. no que toca aos versos 1-2 de 15-18 com Ovídio é notória: cf. Trist.1.1. versos 1-2; 27-28; 61.62. Vide Hinds 2007133.

83 12. Praef: non Hispaniensem librum mittamus, sed Hispanum. Sobre o conteúdo do livro XII, Vide Sullivan 1991 52-55.
} 
e uma subjugação a um novo exílio, com ecos ovidianos ${ }^{84}$. É o preço a pagar por quem tem duas pátrias no coração.

A importância que Marcial dá à Hispânia corresponde à promoção que os Flávios estenderam a estas comunidades através da atribuição do direito latino (ius Latii) que essencialmente tornava cidadãos romanos os magistrados locais e que coincidiu com o incremento da actividade agrícola de larga escala (ao menos em algumas regiões, de que se destaca a Bética: 1.96.5; 6.71.1; 12.65.5), à semelhança da Itália. E o facto de Marcial, ao mesmo tempo que celebra Roma e as glórias de Itália, fazer as laudes da Hispânia $(1.49 ; 1.61)$ não pode deixar de recordar Plínio o Velho (Nat. 37.77), que, depois de considerar a Itália a mais bela e produtiva das terras, coloca a Hispânia logo em segundo lugar, enumerando as suas riquezas.

Em suma, toda a obra de Marcial está ligada à cidade, enquanto comunidade de cidadãos e enquanto espaço físico; enquanto espaço social, artístico e cultural; enquanto espaço do eu poético, do leitor e, de um modo particular, do livro. A poesia de Marcial não pode ser separada de Roma, caso contrário torna-se em grande parte incompreensível. E é uma fonte de informação preciosa para a história das mentalidades, da arquitectura, da topografia de Roma. Também, vista por outro prisma, a poesia não pode ser separada de Bílbilis, porque esta é o ponto de confronto com os aspectos rejeitados da Urbe e a esperança de realização da "cidade ideal" que o poeta sonha: um paradigma que depois se não concretiza. Se Roma é para o poeta a negação de Bílbilis, Bílbilis transforma-se com o tempo na negação de Roma. Feito o confronto realista, Roma fica a ganhar; continua a ser a «deusa das terras e das gentes». E o poeta manifesta a consciência de que com os seus versos imortais contribui para imortalizar estas cidades e os seus dons humanos e materiais.

${ }^{84}$ Comparem-se as palavras non Hispaniensem librum mittamus, sed Hispanum com Ovídio, Trist.3.1.17-18: siqua videbuntur casu non dicta Latine, / in qua scribebat, barbara terra fuit; e Trist. 3.14.49-50: crede mibi, timeo ne Sintia mixta Latinis / inque meis scriptis Pontica verba legas. Há também evidentes ecos de Ovídio no envio do livro para a Urbe em Marcial 12.2 (cf. Trist.1.1): vide Hinds 2007 129-136 e n.58. 


\title{
Uma cidade que fala. Vozes urbanas nas Silvas de Estácio
}

\author{
Ana Maria Lóio \\ Universidade de Lisboa \\ Centro de Estudos Clássicos
}

O percurso biográfico e poético de Estácio liga-o indelevelmente a duas cidades: Nápoles, onde nasceu e viveu até à adolescência e para onde deseja regressar em idade avançada; e Roma, para onde a família se mudou durante o principado de Nero, e talvez com o apoio deste. É esta última a que goza de maior protagonismo nas Silvas, dada a relação estreita entre a celebração do imperador e a da sua cidade.

Tal celebração assume contornos notavelmente originais. Um dos aspectos que Estácio explora no sentido de tornar o panegírico menos árido é a voz que o profere. Figuras mitológicas que habitam locais simbólicos da Roma de Domiciano adquirem voz nas Silvas para fazer, na primeira pessoa, o elogio do imperador. Gostaria de salientar a peculiaridade de duas dessas (muitas) vozes, que poderão ter-se inspirado em oradores invulgares que elogiam os Ptolemeus na poesia helenística. A extraordinária imaginação do poeta terá transformado o estímulo helenístico num Cúrcio regressado à superfície para louvar Domiciano e num Jano honrado por dividir com o imperador o protagonismo que the cabe no primeiro dia do ano.

\section{O regaço de Parténope}

A Nápoles em que Estácio cresceu era a principal cidade grega da Campânia e o maior centro cultural grego no ocidente. Contrariando o acentuado declínio cultural de outras colónias gregas da Magna Grécia, a colónia da Eubeia, tornada municipium em 90 a. C., manteve uma constituição grega, órgãos de governo locais, instituições cívicas e religiosas e um sistema de educação característicos ${ }^{1}$; mais, era política municipal imitar práticas gregas $^{2}$. Do "modo de vida" grego dá testemunho Estrabão, assinalando, entre outros aspectos, o festival que se realizava de quatro em quatro anos, incluindo competições poéticas (5.4.7), e que rivalizava com os mais famosos de entre os gregos. $\mathrm{Na}$ verdade, os Jogos Napolitanos, apoiados pelo imperador, viriam a ser um modelo para festivais a fundar em Roma ${ }^{3}$ É simbólico do "estatuto" da cidade um episódio imortalizado por Tácito e que coloca Nápoles na biografia

\footnotetext{
${ }^{1}$ Hardie 1983 2, Lomas 2003 1031-1032 com bibliografia.

${ }^{2}$ Ver exemplos de tais práticas em Hardie 1983 3-4.

${ }^{3}$ Hardie 1983 3-4.
} 
de Nero. Considerando o seu talento demasiado grande para performances domésticas, o imperador terá decidido estrear-se precisamente no teatro de Nápoles, "quasi Graecam urbem" (Anais 15.33.2).

$\mathrm{Na}$ vanguarda da cultura grega, a cidade constituía local de erudição e lazer de gregos e romanos, que a alimentavam financeiramente. Nápoles era, para as classes romanas mais altas, uma estância balnear, o local onde os endinheirados tinham as suas uillae e onde procuravam a companhia de intelectuais gregos assistiam aos seus espectáculos, adoptavam o traje grego e participavam nos seus jantares ${ }^{4}$. Além disso, jovens de famílias com poder económico do sul da Itália vinham receber instrução em poesia grega a Nápoles, onde também o pai do poeta ensinou antes da mudança para Roma ${ }^{5}$. A cidade foi, consequentemente, um ponto decisivo de intercâmbio cultural. Referindo-se ao principado de Nero, nota Hardie que Nápoles desafia distinções entre grego e romano nos domínios da poesia e da retórica ${ }^{6}$.

É nesta cidade que Estácio cresce e se forma, filho de um grego dedicado à escrita e ao ensino de poesia na sua língua. É possível que o pai do poeta frequentasse a corte de Nero. Hardie coloca a hipótese de que a mudança da família para Roma se relacione com o imperador. Conhecendo-se as suas aspirações culturais, não seria despropositado que Nero tivesse apoiado uma figura napolitana que se salientava na literatura ${ }^{7}$. De resto, a propriedade de Estácio, a que este se refere para agradecer o fornecimento de água que Domiciano lhe facultou, pode ter sido uma oferta imperial ao pai do poeta ${ }^{8}$.

Nas Silvas, Nápoles é Parténope, a sereia que, guiada por Apolo com o auxílio de uma pomba, terá fundado a cidade 9 . Em todos os livros das Silvas se faz o encómio de Nápoles, seja devido às suas qualidades, seja pela grandiosidade das figuras do círculo de Estácio que a ela estão associadas. No livro 1, no epitalâmio em honra de Estela e Violentila, Estácio partilha com a noiva a origem napolitana; ambos nasceram, pois, no regaço de Parténope (1.2.260-2). Já no livro seguinte, a cidade faz parte da deleitosa paisagem de uma das janelas da uilla surrentina de Pólio Félix (2.2.84), o principal patrono de Estácio em Nápoles, e a quem o poeta dedica o livro 3. Isto torna-o o livro mais "napolitano" das Silvas. Logo no primeiro poema, é o deus Hércules, honrado por Pólio com um novo templo, quem refere Nápoles entre os locais

${ }^{4}$ Hardie 1983 2-4.

${ }^{5}$ Sobre o tema ver Hardie 1983 9-10, Nauta 2002200 e McNelis 200269 com bibliografia.

${ }^{6}$ Hardie 1983 3-4.

${ }^{7}$ Hardie 1983 2, 12. Estácio tece comentários sobre a sua vida privada em Silvas 3.5, 5.3.

${ }^{8}$ Hardie 1983 12-14. Sobre a hipótese de Domiciano ter sido aluno do pai de Estácio ver pp. 11-12.

9 Silvas 3.5.78-80, 4.4.52-4, 4.8.45-9. Apolo desempenha frequentemente o papel de divindade patrona da colonização (é esse o caso em Eneida 3.161-2, Tebaida 7.664). Laguna 1992380. 
associados à juventude do patrono de Estácio (3.1.93). Não é de estranhar, pois, que Parténope observe com agrado os jogos atléticos que celebram a dedicação do templo (3.1.151-2) ${ }^{10}$. O mais rasgado elogio da cidade ocorre em Silvas 3.5. Estácio procura persuadir a esposa, Cláudia, a mudar-se consigo para Nápoles. Depois de celebrar a fidelidade da companheira, o poeta elogia a Campânia, para se centrar por fim na sua cidade natal (74-104). O encómio de Nápoles constitui, assim, um argumento no âmbito de uma suasoria. A cidade é elogiada pelo seu meio natural e cultural. Os atractivos de Nápoles são complementados pelos das cidades vizinhas: Baias, Cumas, Miseno, Gauro, Cápreas, Surrento, Pitecusas, Estábias ${ }^{11}$. No livro 4, além de recordar novamente o mito de fundação da cidade (4.4.52-54), Estácio imagina Parténope rejubilando com o nascimento de mais um filho de Júlio Menécrates, genro de Pólio (4.8.1). A cidade deve ainda assumir o papel de protectora do túmulo do pai de Estácio, a quem o poeta dedica um epicédio no último livro (5.3.104-115) ${ }^{12}$. De acordo com Silvas 3.5, o poeta terá planeado regressar para Nápoles após o final do livro 3, publicado no ano 94; mas não é certo que o plano se tenha concretizado ${ }^{13}$.

\section{Roma eloquente}

As Silvas, como poemas que celebram ocasiões, possuem um cariz panegírico que choca a sensibilidade de muitos leitores modernos, em particular quando o elogiado é um imperador que as fontes retratam como uma figura temível e terrível. É-lhe dedicado o primeiro poema das Silvas, que se centra na sua gigantesca estátua equestre. Outro poema celebrará as Saturnais, nas calendas de Dezembro (1.6); e o panegírico toma a forma de uma composição cantando o cabelo do "favorito" de Domiciano, Eárino, em Silvas 3.4. Abre o livro 4 um ciclo dedicado ao imperador: o primeiro poema celebra a tomada do consulado pela décima sétima vez; o seguinte centra-se na Domus Flauia, onde Estácio havia sido convidado a participar num banquete que contava com a presença do imperador; por último, 4.3 enaltece uma obra pública de grande interesse e visibilidade, a Via Domiciana, que liga Sinuessa a Putéolos, facilitando a ligação entre Roma e a região da Campânia.

Independentemente da veracidade dos relatos que fazem de Domiciano uma figura hedionda ${ }^{14}$, e não sendo este o local para discutir a "adesão" de

${ }^{10}$ Este passo coloca um problema textual, exposto em Laguna 1992180.

${ }^{11}$ Sobre Silvas 3.5 ver Laguna 1992 338-392, Nauta 2002 316. Uma perspectiva diferente apresenta Newlands, de acordo com a sua leitura das Silvas como poemas que manifestam ansiedade em relação ao regime de Domiciano (ver Newlands 2002 195-197).

${ }^{12}$ Hardie 1983 67-68 sobre o elogio de Nápoles e de figuras napolitanas.

${ }^{13}$ Ver Nauta 2002204.

${ }^{14}$ Sobre este problema ver Wiseman 1996. 
Estácio ao programa imperial, importa ler o encómio do imperador no seu contexto e apreciar a originalidade que apresenta nas Silvas. Lembrando a proposta feita no início deste trabalho, centrar-me-ei num dos traços mais interessantes dos poemas que homenageiam Domiciano: o facto de o elogio ser proferido, por vezes, por figuras mitológicas que animam locais simbólicos da cidade. Refiro-me concretamente a Cúrcio, que intervém no elogio da estátua equestre de Domiciano em Silvas 1.1, e ao deus Jano, que acolhe e saúda pessoalmente o novo cônsul em Silvas 4.1.

Se é verdade que os oradores mitológicos são recorrentes na épica, uma outra tradição explica melhor o fenómeno nas Silvas. Com efeito, a personificação ou antropomorfização do discurso constituem elementos importantes na poesia panegírica helenística ${ }^{15}$. Coleman apresenta três exemplos de figuras mitológicas que se apropriam do discurso encomiástico ${ }^{16}$ : a eloquente madeixa de cabelo de Berenice, uma das mais famosas criações de Calímaco (fr. 110 Pf.), votada pela rainha pelo regresso do marido, Ptolemeu III, da guerra na Síria; o discurso de Apolo, ainda por nascer, no hino a Delos (4.162-6), impedindo a mãe de o dar à luz na ilha de Cós, destinada a ser o berço de outro "deus", Ptolemeu II; e a ilha de Cós, com o recémnascido faraó nos seus braços, no idílio 17 de Teócrito (64-71), rogando a sua estima e exortando-o a emular o comportamento honroso de Apolo para com o local onde nasceu. Estes oradores são intervenientes pertinentes, pois estão directamente envolvidos nas situações de que o panegírico nasce. Ora, uma atmosfera semelhante aproxima a Roma imperial da Alexandria dos Ptolemeus. Coloca-se aos poetas, em ambos os casos, o problema da abordagem de um governante único. É possível que os poemas que celebram os faraós e os seus monumentos tenham proporcionado modelos encomiásticos aos poetas augustanos e, mais tarde, a Estácio ${ }^{17}$. No contexto augustano, é difícil não reconhecer pontos de contacto entre a tradição encomiástica a que nos temos vindo a referir e o discurso de Apolo em Propércio 4.6, o aetion do templo dedicado por Octaviano ao deus pelo auxílio prestado na batalha de Áccio. É o próprio Apolo que interpela Octaviano, incitando-o à batalha; e a sua intervenção é seguida pela de um outro deus, Júlio César ${ }^{18}$.

${ }^{15}$ Coleman 1988 63-65.

${ }^{16}$ Coleman 1999 76-77 ressalva que a madeixa de cabelo de Berenice se distingue dos outros dois oradores mencionados por proferir todo o poema, e não apenas uma parte, e por não ser uma figura mitológica convencional.

${ }_{17}$ Coleman 1999 78-79.

${ }^{18}$ Propércio 4.6.37-44, 59-60: "E disse: «Ó salvador da terra, oriundo de Alba Longa,| Augusto, de fama superior aos teus avôs Troianos,| vence agora no mar, pois já é tua a terra: por ti combate este arco, | e todas as flechas que trago aos ombros estão do teu lado.| Liberta do medo a pátria, que confiante agora na tua protecção| acumula as preces do povo sobre o teu navio.| Se não a defendes, é porque Rómulo, ao tomar os auspícios da cidade,| interpretou 
Coleman chamou já a atenção para a necessidade de entender o tom do discurso de Apolo à luz da técnica encomiástica helenística. Propércio é acentuadamente mais subtil do que Estácio, mas inspira-se na mesma estratégia encomiástica ${ }^{19}$.

E se não nos limitarmos ao fenómeno da atribuição de voz a figuras mitológicas, encontraremos ainda mais paralelos relevantes entre as Silvas e a celebração de governantes e/ou ocasiões na poesia helenística. A pertinência desta abordagem fica clara quando se compara, por exemplo, Silvas $1.1 \mathrm{com}$ composições que celebram monumentos helenísticos, como o Colosso de Rodes (AP 6.171) e o farol de Alexandria (Posidipo AB 115) ${ }^{20}$; o poema de Estácio relaciona-se, ainda, com as experiências de Calímaco envolvendo estátuas, nos Aetia e nos Iambos ${ }^{21}$. O estudo das Silvas à luz desta tradição afigura-se, pois, necessário: não apenas ajuda a compreender o projecto poético de Estácio, como torna mais evidente a originalidade e a imaginação do poeta.

A “egiptofilia" dos Flávios, e de Domiciano em particular, é um factor a ter em conta quando se equaciona a relação entre o encómio do imperador e o panegírico helenístico. É sabido que Domiciano construiu um complexo de templos egípcios no campo de Marte, dedicados a Ísis e Serápis; no centro deste complexo figuraria o seu obelisco, no qual se leriam títulos faraónicos aplicados ao imperador ${ }^{22}$. Ora, para o governante que exibe estes gostos, seria certamente lisonjeador ser homenageado, em poesia, nos mesmos moldes que os Ptolemeus.

Um outro factor favorece a hipótese de Estácio se ter inspirado na poesia panegírica do tempo daqueles faraós. Chamou-se já a atenção para o perfil do seu pai: segundo o testemunho de Silvas 5.3, ensinara poesia helenística ${ }^{23}$. Além disso, entre as actividades de um poeta profissional encontrar-se-ia o encómio, em ocasiões públicas ou domésticas. Esta vertente do trabalho do

mal as aves que voavam do Palatino. [....]| Lá do astro idálio, César, seu pai, contempla-o com admiração:| «És um deus: esta vitória prova que és do meu sangue.» Cito a tradução de J. A. Segurado e Campos em Nascimento 2002 237-239.

${ }^{19}$ Coleman 2003.

${ }^{20}$ Ver respectivamente Hardie 1983 131-132 e Obbink 2004.

${ }^{21}$ Ao descrever a estátua, Estácio faz, em alguns momentos, associações simbólicas. Talvez Calímaco proporcione um paralelo para tal gesto. O poeta dialoga com a estátua de Apolo num fragmento dos Aetia (114 Pf.); parece dar uma explicação simbólica do arco que Apolo segura com a mão esquerda; na mão direita, tem as Graças. Ver Hardie 1983 132, Kerkhecker 1999 147-197, 204-207.

${ }^{22}$ Ver Malaise 1972.

${ }^{23} \mathrm{O}$ pai de Estácio ensinaria os poetas épicos e didácticos (Homero, Hesíodo, Epicarmo), cinco dos nove líricos, os alexandrinos Calímaco, Lícofron, Sófron, Corina - ficamos a saber no epicédio que Estácio lhe dedica (Silvas 5.3.148-58), com a intenção de mostrar a sua erudição e consequente versatilidade como poeta. 
pai de Estácio terá certamente influenciado de forma decisiva uma obra do carácter das Silvas ${ }^{24}$.

Havia no forum romano um local sagrado e muito antigo, envolto em mistério, associado a várias lendas e considerado uma porta para o "outro mundo". Trata-se do Lago Cúrcio, que recebe o nome, na versão adoptada por Estácio, do herói republicano Quinto Cúrcio, imortalizado pela sua deuotio em 362 a. C. ${ }^{25}$. Reza a lenda que era necessário sacrificar "a maior força do povo romano" para apaziguar os deuses. Cúrcio entendeu que a expressão se referia ao valor dos guerreiros romanos; montado no seu cavalo, atira-se ao pântano, que se fecha à sua entrada, indicando a aceitação do sacrifício ${ }^{26}$. $\mathrm{O}$ acto de Cúrcio coloca-o na galeria dos heróis republicanos como um exemplo de coragem, de valentia, e símbolo da entrega que salva a pátria ${ }^{27}$. É este guerreiro republicano que, em Silvas 1.1, regressa à superfície atraído pelo barulho da operação que visa instalar a imponente estátua equestre de Domiciano, votada após a vitória sobre os $\mathrm{Germanos}^{28}$, perto da sua secular morada. $\mathrm{O}$ guerreiro eternizado pela bravura treme perante $o$ tamanho e o brilho da estátua - reação adequada a quem vive na escuridão do subsolo, num outro mundo, há tantos séculos, e se confronta repentinamente com um monumento gigantesco. Cúrcio mergulha três vezes a cabeça, aterrado, num pântano que já não existe, e só depois se dirige ao novo vizinho:

Saúdo-te, descendente e progenitor de grandes deuses, divindade de que apenas ao longe tinha ouvido falar! Agora é afortunado o meu pântano,]

agora é venerando, pois foi-me permitido conhecer-te de perto

e o teu imortal esplendor contemplar mesmo aqui ao lado.

Uma única vez fui eu que encontrei a salvação de

Rómulo - já tu as guerras de Júpiter, tu as batalhas do Reno, tu o crime civil, tu a montanha que tarda em aderir aos tratados com um longo conflito vergas. Pois se te tivessem gerado os nossos tempos, terias tentado atirar-te ao fundo lago, não me atrevendo eu, mas Roma teria agarrado os teus freios. ${ }^{29}$

${ }^{24}$ Sobre o tema ver Hardie 1983 15-30, McNelis 2002.

${ }^{25}$ Hardie 1983 131-132.

${ }_{26}$ Trata-se de uma versão muito antiga, provavelmente a etiologia original daquele monumento, talvez grega e remontando pelo menos ao século IV a. C. Varrão, De Lingua Latina 5.148-50, oferece três versões do mito. Ver Ogilvie 1970 75-76, Littlewood 2006 127-128.

${ }^{27}$ Fundamental a análise de Coleman 1999 67-70.

${ }^{28}$ A composição de Estácio inspirar-se-á na cerimónia de dedicação da estátua (como o poeta insinua no prefácio ao livro 1), que poderá ter sido conduzida pelo próprio Domiciano, na qualidade de Pontífice Máximo. Estácio parece sugerir o papel duplo de Domiciano como dedicatário e líder da cerimónia religiosa (Hardie 1983 131).

${ }^{29}$ Silv. 1.1.74-83 Courtney: 'Salve, magnorum proles genitorque deorum,| auditum longe 
Silvas 1.1 é um poema longo e complexo ${ }^{30}$ e mereceu interpretações muito diversas $^{31}$. Focaremos apenas alguns aspectos do protagonismo de Cúrcio e a dimensão simbólica da sua epifania e do seu discurso. Cúrcio é uma voz pertinente para proferir o panegírico por vários motivos. O seu estatuto heróico e sagrado proporcionam elementos de apoio ao encómio. O carácter divino de Domiciano é um dado adquirido nas Silvas; por isso, não surpreende que a presença da estátua imperial nobilite o lacus, em vez de ser o lacus a nobilitar o novo monumento. O herói habita a vizinhança da estátua. Acordá-lo e trazê-lo à superfície são maneiras de salientar que aquela causa um enorme impacte no coração da cidade. A orientação da estátua é muito significativa. $\mathrm{O}$ cavaleiro olha na direcção do templo de Júlio César, o que oferece ao poeta um pretexto para comparar Domiciano àquele governante (o imperador supera-o em clemência e teria evitado as guerras civis); está ladeado pelas Basílicas Júlia e Emília e protegem-lhe as costas os templos de Tito e Vespasiano e o templo da Concórdia.

O imperador integra um novo elemento, a estátua, na mais simbólica zona de Roma, tomando posição entre os antigos vultos da cidade, enfrentando-os e superando-os; são disso exemplo César e Cúrcio. O guerreiro assinala a distância que o separava do imperador, contrastando-a com a actual proximidade. Esta ultrapassa a dimensão física, topográfica, sugerindo uma analogia entre um

numen mihi. nunc mea felix,| nunc veneranda palus, cum te prope nosse tuumque| immortale iubar vicina sede tueri| concessum. semel auctor ego inventorque salutis| Romuleae: tu bella Iovis, tu proelia Rheni,| tu civile nefas, tu tardum in foedera montem| longo Marte domas. quod si te nostra tulissent | saecula, temptasses me non audente profundo| ire lacu, sed Roma tuas tenuisset habenas.'

${ }^{30}$ Depois de exprimir o espanto que a gigantesca estátua suscita, alvitrando que poderia ser obra de um deus (1-7), Estácio compara-a favoravelmente ao cavalo de Tróia (8-21) e centra-se no local que ela ocupará, digno da sua grandiosidade (22-31). A descrição da estátua começa pelo cavaleiro, mais alto que os templos, travando guerras com a mão direita e exibindo na esquerda uma estatueta de Minerva (32-45); foca então o cavalo, comparado a alguns dos mais notáveis das artes e mitologia (46-55), para terminar no impacte da sua presença e força que empresta às mãos daqueles que trabalham em tão grandiosa obra (56-66). Depois da epifania de Cúrcio e do seu discurso, a estátua é dita superar a de Júlio César - em frente ao templo do Divino César - na mesma medida em que o novo governante supera o antigo (84-90). Canta-se, por fim, a eternidade da obra - superior a monumentos como o Colosso de Rodes -, que será visitada pelos membros divinizados da família imperial (91-98) e que é apresentada como uma oferenda do senado e do povo ao imperador, a quem se deseja uma vida longa (99-107). Consulte-se Geyssen 1996, monografia exclusivamente dedicada ao poema.

${ }^{31}$ Alguns críticos discernem em Silvas 1.1 um conjunto de críticas veladas a Domiciano, numa corrente interpretativa a que aludimos na nota 11. É o caso de Ahl 1984a e Ahl 1984b. Não é esta a minha leitura; apresenta igualmente reservas em relação àquela perspectiva L. Morgan, BMCR 2002.09.13. Ver ainda E. Spentzou (2004), JRS 94 257-8; S. Myers (2004/5), CJ 100 213-215; W. J. Dominik (2006), CR 56 359-360. 
“salvador" de Roma e o outro ${ }^{32}$. Mas Domiciano supera sempre Cúrcio: o herói republicano é ofuscado pelo herói que ao seu lado se instala. Cúrcio salvou Roma apenas uma vez, Domiciano fê-lo repetidamente - um pretexto para Estácio elencar as vitórias do imperador. Até em coragem o novo vizinho teria ultrapassado Cúrcio. Roma tê-lo-ia impedido de atirar-se ao pântano no seu lugar porque a cidade precisa que o imperador viva.

Mas a propriedade deste orador justifica-se ainda de outra maneira. $\mathrm{O}$ poeta refere que é o próprio Cúrcio quem guarda o local. Hardie chama a atenção para a hipótese de que, quando se erigisse um objecto numa terra do interesse de outra divindade, essa mesma divindade local fosse interpelada. É o caso do epigrama de Posidipo sobre o grande farol de Faros: a composição é dirigida a Proteu, o patrono do local, mas o farol é dedicado aos "deuses salvadores" e a Zeus Sóter, epítetos que dificilmente não pretenderiam incluir os Ptolemeus ${ }^{33}$. Ora, o discurso de Cúrcio pode, pois, substituir a interpelação ao protector do local, invertendo a tradição - o interpelado, que seria Cúrcio, guardião secular daquele sítio, desempenha em Silvas 1.1 o papel daquele que interpela; e a divindade a quem o poema é dirigido, o dedicatário da oferenda, é o próprio imperador.

A dignidade e a credibilidade desta voz mítica tornam o cumprimento a Domiciano elegante ${ }^{34}$. O estatuto lendário de Cúrcio permite que o poeta crie um discurso grandioso, dando-lhe formalidade, solenidade - um registo adequado ao encómio de um imperador e de um deus ${ }^{35}$.

Estácio volta a inverter as expectativas em Silvas 4.1, que assinala o décimo sétimo consulado de Domiciano, no ano 95. No início de um novo livro, de um novo ano e de um novo consulado, o poema é dominado pela saudação que o próprio deus dos inícios, Jano, dirige ao imperador ${ }^{36}$. Trata-se de uma gratiarum actio, um agradecimento a Domiciano por ter aceitado a honra de ser novamente cônsul ${ }^{37}$; o consulado é apresentado, pois, como uma cedência do imperador à pressão do senado. As leis, as magistraturas e toda a Roma se alegram, e até as estrelas; mas Domiciano brilha mais do que elas. Os motivos do júbilo universal e do consulado como cedência são reiterados por Jano, que se coloca a par do imperador no papel de renovador dos anos e insiste na ausência de paralelo, na história de Roma, para o desempenho de Domiciano como governante:

\footnotetext{
${ }^{32}$ É questão colocada por Coleman 199969.

${ }^{33}$ Hardie 1983 131-132.

${ }^{34}$ Como nota Coleman 199970 a propósito de Cúrcio.

${ }^{35}$ Coleman 199969.

${ }^{36} \mathrm{Um}$ estudo das fontes do discurso passa necessariamente pelos Fastos. Jano é o orador no primeiro dia (Fast.1.101-44).

${ }^{37}$ Hardie 1983193.
} 
Saúdo-te, grande progenitor do mundo, que comigo procuras renovar os séculos! Nessa qualidade deseja ver-te sempre no meu mês a tua Roma. Assim devem nascer os tempos, assim começar os anos. Oferece aos fastos sem parar motivos de júbilo! Esses ombros, que os envolva a pretexta com abundante púrpura tecida pelas mãos da tua Minerva. Vês como existe um brilho diferente nos templos, um fogo mais alto nos altares, e as próprias estrelas do meu inverno cintilam para ti, iguais às tuas virtudes? Exultam os cavaleiros e os povos, e os senadores vestidos de púrpura, e toda a magistratura toma do cônsul a sua luz. Que ano anterior, pergunto-te, teve algo parecido? Vamos, diz, poderosa Roma, e comigo, longa Antiguidade, enumera os fastos e não tragas a lume os exemplos menores, mas apenas aqueles que o meu César se digne superar.

Três e mais dez vezes, no decorrer dos anos,

Augusto transportou os lácios fasces, mas tarde começou a merecê-lo:

tu, ainda jovem, ultrapassaste os teus avós. E a quanto renuncias, quanto não permites! Hás-de ser persuadido, todavia, pelas preces do senado, e hás-de consentir muitas vezes este dia. Está por vir uma série

mais extensa, e dar-te-á outras tantas a próspera Roma o ofício curul, e três e quatro vezes mais. Comigo nova idade hás-de fundar, e por ti será novamente inaugurado o altar do antigo Tarento. Hás-de carregar mil troféus - consente, apenas, os triunfos. Falta à Báctria, falta à Babilónia com novos tributos pôr o freio; ainda não está no regaço de Júpiter o loureiro índico, ainda não apresentam petições os árabes e os chineses, ainda não foi honrado todo o ano - dez meses desejam ainda nomes tomados de ti.

(Silv. 4.1.17-43) 38

38 Silv. 4.1.17-43 Coleman: 'Salve, magne parens mundi, qui saecula mecum| instaurare paras, talem te cernere semper| mense meo tua Roma cupit; sic tempora nasci,| sic annos intrare decet. da gaudia fastis| continua; hos umeros multo sinus ambiat ostro| et properata tuae manibus praetexta Minervae.| aspicis ut templis alius nitor, altior aris| ignis, et ipsa meae tepeant tibi sidera brumae| moribus aequa tuis? gaudent turmaeque tribusque| purpureique patres, lucemque a consule ducit| omnis honos. quid tale precor prior annus habebat?| dic age, Roma potens, et mecum, longa Vetustas,| dinumera fastos, nec parva exempla recense| sed quae sola meus dignetur vincere Caesar.| ter Latios deciesque tulit labentibus annis| Augustus fasces, sed coepit sero mereri:| tu iuvenis praegressus avos. et quanta recusas,| quanta vetas! flectere tamen precibusque senatus| permittes hunc saepe diem. manet insuper ordo| longior, et totidem felix tibi Roma curules| terque quaterque dabit. mecum altera saecula condes,| et tibi longaevi renovabitur ara Tarenti.| mille tropaea feres - tantum permitte triumphos.| restat Bactra novis, restat Babylona tributis| frenari; nondum in gremio Iovis Indica laurus, | nondum Arabes Seresque rogant, nondum omnis honorem| annus habet, cupiuntque decem tua nomina menses.' 
Tradicionalmente, o cônsul fala em nome da República; por analogia, o Jano de Estácio fala por Roma, referindo-se à cidade no início das três secções do seu discurso: o comentário da situação presente (17-27), o passado e os seus precedentes (27-33), o futuro (33-42) $)^{39}$. Roma é pertença de Domiciano, omnipotente e próspera.

A atribuição de voz a Jano e a extensão do seu discurso, que ocupa boa parte do poema, são aspectos muito significativos. É costume que o cônsul que entra em funções faça o discurso de gratiarum actio ao imperador pelo beneficium do cargo; mas podia também dar-se o caso de o novo cônsul interpelar directa e pessoalmente $\mathrm{Jano}^{40}$. Estácio explora imaginativamente esta possibilidade. $\mathrm{O}$ poeta inverte os discursos: em vez de o novo cônsul interpelar Jano, é o deus quem interpela o cônsul. Esta é igualmente uma maneira elegante de contornar uma situação melindrosa, o facto de ser o imperador a assumir o consulado.

A legitimidade de Jano para interpelar Domiciano pode conhecer outros fundamentos. Jano estava associado a Aion, a deificação do conceito de eternidade. Ora, testemunhos poéticos e algumas moedas sugerem a hipótese de que Domiciano fosse assimilado às funções de Jano-Aion, representando a eternidade de Roma e do império ${ }^{41}$.

Há ainda mais um aspecto a considerar na relação entre Jano e o imperador. Existia um templo dedicado a Jano no final do Argileto, formando um corredor entre o forum romano e o de César, no local onde Domiciano mandou erguer a nova Cúria em 94. O deus apresentaria duas faces, justificando o nome Geminus, e o templo teria duas entradas. Por ocasião das obras da Cúria, o imperador ofereceu ao deus um novo templo, no qual Jano figuraria com uma outra morfologia, com quatro faces, o que explica a sua designação, Jano Quadrifronte. Domiciano instalou-o no forum por si idealizado, entre o de Augusto e o Templo da Paz. O forum era conhecido como "transitorium" por constituir o principal caminho entre a Subura, o forum romano e os outros fora imperiais ${ }^{42}$, e exibiria detalhes arquitectónicos semelhantes aos do palácio imperial. Num extremo do forum erguia-se o templo em honra da deusa preferida de Domiciano, Minerva, e no centro ou no extremo oposto encontrar-se-ia o templo de Jano Quadrifronte. Cada face do deus contemplaria, simbolicamente, um forum: o de César, o de Augusto, o forum romano e novo forum de Domiciano. É ainda de assinalar que esta localização o tornava vizinho do Templo da Paz, a que Jano se encontra proverbialmente associado. Marcial celebra este monumento no livro 10:

\footnotetext{
${ }^{39}$ Hardie 1983193.

${ }^{40}$ Ver Silv. 4.2 e Mart. 8.8. Com Hardie 1983 193, nota 71.

${ }^{41}$ Hardie 1983193.

${ }^{42}$ Platner - Ashby 1929 278-280.
} 
Pai magnífico dos anos e do luminoso universo,

o primeiro que invocam as preces e os votos públicos,

antes habitavas uma morada exígua, ponto de passagem

por onde Roma em peso trilhava o seu caminho.

Agora teus limiares enchem-se das dádivas de César

e contas tantos foros, Jano, quantas são as caras.

Mas tu, pai venerando, grato por tamanha oferenda, guarda tuas férreas portas fechadas com aldraba sempre posta. ${ }^{43}$

Parece-me relevante que Jano seja, além da divindade associada aos inícios e à tomada da magistratura consular, o deus honrado por Domiciano com um novo templo, numa localização privilegiada - no forum concebido pelo imperador, na vizinhança da sua Minerva, e com o simbolismo de unificar os fora, o coração de Roma. Se a estátua equestre de Silvas 1.1 dominava o perímetro do forum romano e os edifícios circundantes, o novo Jano articula as principais praças da cidade, símbolos de outras fases da história de Roma, marcas de outros governantes. Tal articulação seria particularmente clara se o templo tivesse de facto quatro entradas e ocupasse a extremidade do forum de Domiciano ${ }^{44}$. Permanece em dúvida, no entanto, de onde é que Estácio imagina o deus proferindo o seu discurso em honra do imperador. $\mathrm{O}$ modo como Estácio descreve o deus adequa-se mais à sua figuração como Geminus - possui uma "voz dupla", são referidas duas entradas (Silv. 4.1.12, 16); no entanto, Jano parece encontrar-se perto do Templo da Paz, o que se ajusta à sua nova localização (Silv. 4.1.13). Na proposta de Coleman, as referências não são incompatíveis: Jano dirige-se ao imperador do seu mais antigo templo, aludindo igualmente ao novo ${ }^{45}$.

3. Nos poemas de Calímaco e Teócrito a que nos referimos atrás, a fantasia encontra-se ao serviço do panegírico. $\mathrm{O}$ mesmo pode dizer-se dos poemas das Silvas em que a palavra é dada a uma figura mitológica: o orador concretiza a fusão do mundo real com o mítico, possibilidade posta ao serviço do elogio, emprestando-lhe originalidade, diversificando-o. Com efeito, o "aparecimento" do orador justifica uma breve narrativa introdutória; a sua envergadura mitológica faz dele uma figura com propriedade para discursar, permitindo assim a variação da voz que profere o encómio; o artifício permite, ainda, avançar e recuar no tempo ${ }^{46}$, comparar passado e presente. É prática de

${ }^{43}$ Marcial 10.28. Cito a tradução de Paulo Sérgio Ferreira em Pimentel 2004 34-35.

${ }^{44}$ A localização do templo a Jano Quadrifronte é disputada. Permanece igualmente em aberto a morfologia do templo, tanto o de Jano Geminus como o de Jano Quadrifronte. Ver Anderson 1984137 com bibliografia; Platner-Ashby 1929 280; Coleman 1988 62-65, 69-71.

${ }^{45}$ Coleman 198871.

${ }^{46}$ Coleman 1999 78-79. 
Estácio, à semelhança do que sucede nos poemas gregos referidos, atribuir o discurso a uma divindade que esteja associada ao local ou à ocasião ${ }^{47}$. Cúrcio e Jano constituem, pois, oradores cuidadosamente seleccionados. Ambos se enquadram no cerimonial da ocasião que celebram, Cúrcio fazendo o papel da divindade local, Jano como o deus a quem o discurso do início do ano poderia ser endereçado. Estácio joga com as convenções das cerimónias, adaptando-as às necessidades da poesia; é assim que o destinatário convencional de um discurso toma o lugar, no universo de Estácio, de orador.

Mas Cúrcio e Jano têm ainda outro aspecto em comum: testemunham a apropriação do espaço por parte de Domiciano. O fenómeno repete-se, de resto, no caso da Via Domiciana (Silv. 4.3), celebrada na voz do rio Volturno, drenado e canalizado no decurso da obra, e da Sibila de Cumas, símbolo do final da viagem a sul. Ao dar voz a Cúrcio e Jano, Estácio acaba por chamar a atenção para aspectos da intervenção urbanística do imperador ${ }^{48}$. As duas figuras são símbolos de uma Roma em transformação. Domiciano procura abrir espaço para si entre as marcas deixadas por aqueles a quem outrora pertenceu a cidade.

${ }^{47}$ Coleman 198865.

48 Sobre a intervenção de Domiciano na cidade existe abundante bibliografia, da qual saliento Darwall-Smith 1996. Ver também Dewar 2008 65-72. 


\title{
ESPAÇo E PERSPETIVA NA OBRA DE JUVENAL E NA SÁTIRA MENIPEIA ${ }^{1}$
}

\author{
Paulo Sérgio Ferreira \\ Universidade de Coimbra \\ Centro de Estudos Clássicos e Humanísticos
}

\section{O emissor}

Em R. 394c., observa Sócrates:

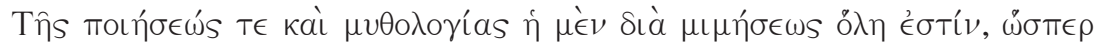

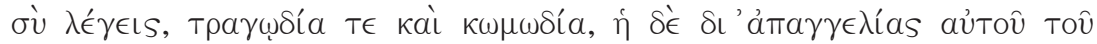

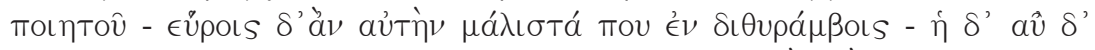

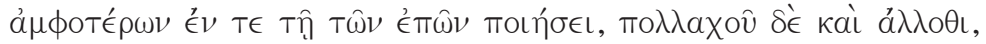

"em poesia e em prosa há uma espécie que é toda de imitação, como tu dizes que é a tragédia e a comédia; outra, de narração pelo próprio poeta - é nos ditirambos que pode encontrar-se de preferência; e outra ainda constituída por ambas, que se usa na composição da epopeia e de muitos outros géneros."

Das palavras platónicas citadas, o que se depreende é a importância do emissor na definição dos modos e dos géneros literários: se o modo dramático se carateriza por fazer dos atores em sentido etimológico, isto é, das personagens, instâncias de enunciação, já, nos ditirambos e provavelmente no modo lírico, é, de acordo com Platão, o próprio poeta quem narra.

Murray observa que Platão «differs most significantly from his predecessors in maintaining that inspiration is incompatible with techne» ${ }^{3} \mathrm{e}$ ao negar ao poeta o estatuto de artífice (v. R. 601d1-2), e vê na perspetiva platónica uma reação à tendência contemporânea para a profissionalização da atividade poética. Não deixa, contudo, a investigadora de notar o caráter ambíguo da inspiração na obra do filósofo. As personagens platónicas, por um lado, reconhecem que o poeta domina a dicção, o metro, o ritmo e a melodia ( $R$. 393d8); que a inspiração divina garante a verdade e a qualidade da obra (Ion 534d); e que uma alma tenra e possuída pela loucura das musas é superior à de um poeta versado ( $P h d r$. 245a); mas, por outro, notam que o nível de loucura poética é inversamente proporcional à capacidade de descrever o processo criativo, compreender o assunto e explicar o significado da sua poesia (Ap. 22b-c); que,

\footnotetext{
${ }^{1}$ À saudosa memória de um grande Mestre e Amigo: o Prof. Doutor Aníbal Pinto de Castro.

${ }^{2}$ Trad. de Maria Helena da Rocha-Pereira 2007118.

${ }^{3}$ Murray 19969.
} 
enquanto alguém que se limita a jogar com as palavras $(P h d r .278 \mathrm{c}-\mathrm{d})$, não vai o poeta além do sexto lugar em ranking de profissões que, nos dois primeiros p. ex., posiciona o filósofo e o homem de negócios (Phdr. 248d-e). ${ }^{4}$

Embora, à luz de uma tradição que remonta a Homero e se prolonga por Hesíodo e pela produção poética arcaica e posterior, se possa ver, na crença dos autores gregos na dimensão divina da inspiração poética, uma valorização do papel, no processo literário, do que a moderna Teoria da Literatura designou por "autor empírico", a verdade é que a referida ambiguidade no modo como Platão encara a inspiração poética, eventualmente decorrente da sua condição de autor e leitor, ora potencia uma perspetiva do poeta como uma espécie de personagem que o leitor infere e associa ao imaginário mítico-religioso grego, ora o situa num plano meramente humano, semântica e pragmaticamente ligado ao meio onde vive e ao contexto em que escreve. Não será, de resto, por acaso que se, em $A p$. 20d-e e 29a-b, manifesta Sócrates consciência dos limites do conhecimento e se não atreve a reclamar para si uma sabedoria divina, mas humana, já, em $L g .719$ c, aparece a inspiração poética associada a uma diluição, no processo imitativo, do poeta em personagens contrastantes, de modo a, desconhecedor da verdade, entrar em contradição. Ora a perspetiva adotada nas Leges, que consiste na consideração de uma entidade a partir das personagens por ela criadas, é claramente a de um leitor que procura definir os contornos de um autor textual.

Ao escrever, na última década da sua vida, o passo considerado das Leges, talvez tenha Platão tido em conta a Comédia Antiga, com a sua invetiva e a sua metateatralidade, e, em particular, as Ranae, levadas à cena em 405 a.C., onde, de um debate entre Ésquilo e Eurípides pelo trono da poesia, pode o leitor depreender um autor textual cuja avaliação de ambos os trágicos negligencia e exagera aspetos das respetivas poéticas que Aristófanes, enquanto autor empírico, seguramente conhecia. Ao chamar a Eurípides «cerzidor de farrapos» (842), parece Ésquilo esquecer o estado em que o seu próprio Xerxes se apresentara ao público no final dos seus Persae. Quando Ésquilo, em Ra. 868ss., sustenta que, em contraste com a sua própria poesia, a de Eurípides acompanhara na morte o seu autor, lança ao mais novo dos três trágicos uma farpa que, ao cabo e na época do próprio Aristófanes, era já uma inverdade, uma vez que, no séc. IV e nos seguintes, Eurípides era muito mais popular que o autor da Orestea. É certo que, em 947, alude o Ésquilo aristofânico à tradição de que a mãe de Eurípides teria sido vendedeira de hortaliça, mas, à luz dos dois passos anteriores, e do contraste entre 1044, onde Ésquilo afirma nunca ter imaginado uma mulher apaixonada, e Ésquilo, A. 606-10, onde a «insistence» de Clitemnestra «on her own chastity» constitui, segundo

\footnotetext{
${ }^{4}$ Murray 1996 9-12.
} 
Mader, «an attempt to pre-empt criticism from the chorus» ${ }^{5}$, e ainda à luz da consequente relativização da ideia defendida pelo trágico de que não pusera em cena maus exemplos, facilmente se suspeitam possíveis divergências entre o autor empírico e o textual.

Da Comédia Antiga herdou a sátira menipeia toda uma dimensão paródica e metapoética que induziu Relihan a sustentar que Menipo não teria feito parte da seita cínica, mas tão só imitado, de forma ridícula, o pensamento e o registo dos cínicos. Nessa medida e apesar da consciência de que Menipo nada havia escrito, considerou o investigador, entre as características da sátira menipeia, «the parody of the author who has dared to write in such an unorthodox way» ${ }^{6}$. Semelhante perspetiva já havia Biagio Conte adotado na análise do Satyricon de Petrónio, ao considerar que o alvo último do autor escondido eram os intelectuais que constantemente fazia cair no ridículo. Neste caso, porém, talvez se possa admitir a possibilidade de se tratar de uma aprendizagem, traduzida em distanciamento crítico, do narrador autodiegético, no momento de organizar discursiva e coerentemente o seu passado, relativamente ao caos das experiências vividas. Na Diui Claudii Apocolocyntosis, é um narrador heterodiegético quem, em clara paródia dos prefácios e registo historiográficos, tanto proclama a sua imparcialidade (baec ita uera, 1.1.1), como exulta com a liberdade, decorrente da morte do tirano Cláudio, de revelar, ou não, a sua fonte de informação e de dizer o que the apetecer; ${ }^{7}$ ora remete quem the pergunta por fontes para Lívio Gemínio - zelador da Via Ápia que, subornado por Calígula, afirmara ter visto a irmã do imperador, Júlia Drusila, subir aos céus, e, desacreditado no senado, jurara nunca mais testemunhar perante mais do que uma pessoa, mesmo que tivesse visto um homem assassinado no meio do Foro (1.1.2-3)-, ora parodia perífrases e circunlóquios de tempo e espaço, tão caros a maus poetas (1.2.1-4).

É, por conseguinte, numa tradição cómica, que suscitou certa reflexão filosófica e encontrou eco na sátira, que se deve enquadrar a polémica em torno da identificação e da caracterização da instância de enunciação na obra de Juvenal.

Em contraste com uma reflexão biografista de Highet, ${ }^{8}$ procurou W. B. Anderson, em obra que fez escola e com base em critérios como a incoerência entre as proclamações de discurso despojado e linear e o recurso a figuras retóricas, entre a imparcialidade e a fidedignidade proclamadas e a distorção e

\footnotetext{
${ }^{5}$ Mader 198852.

${ }^{6}$ Relihan 199310.

${ }^{7}$ Si quis quaesiuerit unde sciam, primum, si noluero, non respondebo. Quis coactutus est? Ego scio me liberum factum, ex quo suum diem obiit ille, qui uerum prouerbium fecerat, aut regem aut fatuum nasci oportere. Si libuerit respondere, dicam quod mibi in buccam uenerit (Séneca, Apoc. 1.1.1)

${ }^{8}$ Highet 1954.
} 
o exagero verificados no tratamento dos temas, entre manifestações de aversão ao vício e a tendência efetiva para o sensacionalismo, entre preocupações morais manifestadas e o comprazido ataque às vítimas, entre a racionalidade proclamada e a irracionalidade subjacente às atitudes, demonstrar que, nas primeiras sátiras, o alvo de Juvenal é a própria instância de enunciação que, de forma desajustada, critica a Roma de Trajano e de Adriano. Além disso, sustentou o referido investigador que o público romano tinha consciência das diferenças entre ficção e não-ficção; que a indignatio de Juvenal é um reflexo da irracionalidade que Séneca deteta na ira provocada por ofensas pessoais e pela consciência da corrupção que grassa em Roma; que, se a persona que enuncia as seis primeiras sátiras é ridiculizada, já a de 7-9 faz a transição para a de 10-16, que, digna de confiança, sincera e sem nada de ridículo, se aproxima do sentir do próprio autor empírico. ${ }^{9}$ S. M. Braund, citada por Iddeng, considera a ironia como a marca das sátiras do terceiro livro. ${ }^{10}$ Anderson ainda sustenta que o público antigo se divertiria com a exibição de "honesta indignação". ${ }^{11}$

Iddeng objetou, porém, que os autores antigos não tinham consciência da distinção entre autor e instância de enunciação; que não existem, além dos poemas, outros testemunhos que nos permitam reconstituir a mundividência do autor; que, com base nos referidos critérios, igual incoerência e irracionalidade se poderá encontrar no Panegyricus, da autoria de Plínio-o-Moço, e na obra de Tácito; que obras como as Orationes de Cícero e as Epistulae de Plínio, pela preocupação retórica e estilística, e o Bellum ciuile de Lucano, pelas implicações políticas, são a prova acabada de que o público romano não prestava grande atenção à distinção entre ficção e não-ficção; que, mais importante do que a imparcialidade, era, para historiadores e biógrafos, a verosimilhança; que Anderson não havia considerado a possibilidade de o pensamento de Séneca não ter sido o dominante na época de Juvenal, negligenciara a influência da indignatio luciliana e não tivera em conta o facto de as sátiras não explicitarem qualquer conexão com Séneca, de, na obra do último, nunca a ira ocorrer como sinónimo de indignatio, de ambas as palavras serem etimologicamente diferentes, e de haver autores ilustres que, no tocante à ira, discordavam de Séneca (cf. Plínio, Ep. 4.20, Cícero, Catil. 1.12). ${ }^{12}$ Visto que o Cordubense não apreciava a simulação de ira por parte do orador, mais conviria a Juvenal - atalhou Iddeng - seguir Quintiliano, Inst. 6.2.26-36, e Cícero, Inu. 1.100-9, que respetivamente sustentavam que o melhor orador seria o que com mais

\footnotetext{
${ }^{9}$ Anderson 1982 293-324.

${ }^{10}$ Iddeng 2000123.

${ }^{11}$ Anderson 1982390.

${ }^{12}$ Iddeng 2000 110-117.
} 
qualidade simulasse emoções e, por meio de loci-identificados por Braund em Juvenal -, suscitasse no público a indignatio. ${ }^{13}$

Argumentou ainda Iddeng que, se o enunciador fosse objeto de ridículo, dificilmente se justificaria a preocupação de ofender poderosos; que, de acordo com Horácio, S. 2.1.32-4, Lucílio expusera a sua própria vida como numa tabuinha votiva; que Catulo e Calvo criticaram impunemente nobiles, e Varrão, os primeiros triúnviros; que a liberdade de expressão incomodara Sula, que talvez tenha promulgado leis para a limitar (Ulpiano, dig. 47.10.5.8ss.); que, de acordo com Trebónio, também Cícero terá escrito, contra um opositor político, versos à maneira Luciliana (Fam.12.6.3), e nem por isso conseguira melhorar as relações com a fação de Marco António, que, por meio de Dolabela, o capturou e matou quando era procônsul na Ásia; que a sátira era usada com propósitos políticos pelo círculo estoico de Sexto Pompeio, e, despojada por Horácio de invetiva e insultos, acabou por encontrar, em outro estoico e adepto da República, Pérsio, novo cultor; que, conforme se depreende de Horácio, a liberdade de expressão era proporcional ao poder de cada patrono; que, em contraste com o que sustenta a citada Braund (que os poemas são monólogos dramáticos ditos por uma primeira pessoa), as referências subsistentes não sugerem outra atualização para as sátiras que não seja a leitura e que o desempenho de papéis nos exercícios das escolas de retórica mais não era do que uma forma de gestão, por parte de um poderoso grupo de falantes, da sua hegemonia; que, à exceção da figura de Névolo em 9, não existe, na obra de Juvenal, outra personagem que com a instância enunciativa dialogue; que, se a Sat. 13 contradiz a indignação das anteriores, tal se fica a dever à influência da diatribe moral horaciana, e tal transformação não chega a afetar o propósito de Juvenal de denúncia do vício e da maldade; que nada sugere a possibilidade de o leitor de Juvenal o distinguir de uma instância enunciativa; que se o decurso de dois séculos até ao primeiro testemunho subsistente (Lactâncio, Dininae Inst. 3.29) sobre Juvenal e a sua obra se poderá dever à vertente crítica da obra e à correlativa censura, é a essa mesma vertente crítica da obra e à consciência da sinceridade da instância enunciativa que se deve a redescoberta, no séc. IV e por intermédio de Sérvio, do referido satírico. ${ }^{14}$

Quanto ao argumento de Iddeng de que os antigos não distinguiam do autor empírico a instância de enunciação, além de, à luz dos passos aristofânicos e platónicos considerados, poder ser relativizado, perde, por completo, a validade se se pensar no papel do leitor na configuração de uma entidade como o autor textual. É certo, por outro lado, que Heródoto e Tito Lívio integram nas suas obras informações de natureza mitológica e fabulosa, mas se o primeiro não

\footnotetext{
${ }^{13}$ Iddeng 2000118.

${ }^{14}$ Iddeng 2000 119-127.
} 
deixa de ressalvar que não teve forma de comprovar a informação veiculada, já o segundo justifica, com um propósito paradigmático e de engrandecimento dos primórdios de Roma, a opção de misturar o humano com o divino. No plano da poética explícita, distingue Aristóteles, da historiografia que trata o particular, a poesia que tem por alvo o universal, isto é, o que poderia suceder de acordo com a necessidade e a verosimilhança. Por fim, adverte Iddeng: "I am not questioning the need sometimes to keep the speaker apart from the author, and thus in a sense see him as a literary creation." ${ }^{15}$ Mas, do ponto de vista ontológico, o autor empírico, o autor textual e a instância de enunciação são sempre entidades distintas, que podem coincidir mais ou menos nos pontos de vista. ${ }^{16}$ Além de a liberdade de expressão ser proporcional ao poder do patrono, conforme sugeriu Horácio, era, como se depreende da Diui Claudii Apocolocyntosis, inversamente proporcional ao poder do visado pela sátira. Impõe-se então uma reavaliação da relação entre autor empírico e instância de enunciação na obra de Juvenal.

Quer se considere um reflexo da realidade contemporânea ou uma situação ideal, a integração dos aedos homéricos nas respetivas cortes, não restam dúvidas da importância, para a criação artística grega, da hospitalidade não só nesta época como também na arcaica, na clássica e até na Helenística. No referido período ainda se registava um contraste entre situações que muito se aproximavam da relação patrono-cliente e não só as medidas para lhes pôr termo, mas também a ausência de depoimentos que considerassem este tipo de interações como pressupostos para a criação artística, até sensivelmente à época em que Dionísio de Halicarnasso 2.9.2 (cf. Plutarco, Romulus 13) pela primeira vez empregou o termo pelates como equivalente do latim clientes. ${ }^{17}$

${ }^{15}$ Iddeng 2000127.

${ }^{16}$ Sobre o assunto, escreveu Aguiar e Silva 1994 222: "É necessário, porém, distinguir adequadamente entre o autor enquanto sujeito empírico e histórico, cujo nome civil figura em regra na capa e no frontispício das suas obras - um cidadão juridicamente identificável, com um determinado estatuto social, profissional, etc. - e o emissor que assume imediata e especificamente a responsabilidade da enunciação de um dado texto literário e que se manifesta sob a forma e a função de um eu oculta ou explicitamente presente e actuante no enunciado, isto é, no próprio texto literário."

${ }^{17}$ De Demódoco, o aedo que no palácio de Alcínoo dá conta dos feitos de Ulisses, diz Segal 1994115 que "is a permanent fixture in the royal establishment and has a respected place and regular duties there", mas, em parte posterior do estudo, oscila o investigador entre a possibilidade de se tratar de uma situação ideal tanto para o poeta como para o público, e a de a aristocracia grega do séc. VIII poder suportar os custos relativamente modestos associados à manutenção de aedos nos palácios reais. Conforme se depreende do exemplo de Ulisses no país dos Feaces, ou dos de Álcman, Anacreonte, Baquílides, Píndaro e Simónides, que exerceram as respetivas atividades poéticas nas cortes de tiranos como Cípselo de Corinto, Pisístrato de Atenas, Polícrates de Samos, e Hierão de Siracusa, era a hospitalidade que criava condições para a criação poética. No tocante a Píndaro, p. ex., refere Kennedy uma sequência ritual onde os feitos e a glória do herói em honra do qual se celebravam os jogos eram compensados pelas 
No universo satírico latino, notou Iddeng o facto de Lucílio só ter moderado as suas críticas depois da morte de Cipião e Lélio. ${ }^{18}$ Quanto a Horácio, apesar de, em $S .1 .6 .2$, de Mecenas dizer que não há ninguém mais generoso (nemo generosior est te), e de, em 1.6.52-64, se regozijar com o facto de o valido de Augusto não ter tido em conta a pouca ilustração do pai do poeta e ter contado o poeta entre o número dos seus amigos, a verdade é que, em 1.9.48-52, não deixa de esclarecer o maçador sobre a imunidade da casa de Mecenas a intrigas palacianas e jogos de interesses e de poder, e, ao agradecer em 2.6.57-58 a quinta da Sabina, afirma a estranheza das pessoas quando diz nada saber dos segredos de Estado. ${ }^{19}$

vitórias dos atletas, que, por sua vez, reclamavam um poema que as glorificasse. E concluía o investigador (1989 13): "And the song in turn demands compensation from the victorious athlete and his family, to be offered to the composer of the song (e.g., Pythian 9.93)."Ao considerar alguns casos de patronato antes da Revolução Democrática de 462, referiu Millett 1989 18-25 a pacífica convivência de Hesíodo, em Opera et Dies, com uma relação de dependência de outros para consigo; a situação dos hektemoroi, isto é, dos semeadores a meias que tinham de pagar de renda da terra um sexto da produção, e dos pelates, que, geralmente tidos como 'vizinhos', no período de dificuldades da plebe que conduziu ao arcontado de Sólon em 596; a situação dos pobres de Mégara que, por alturas do arcontado de Sólon, invadiam as casas dos ricos para se banquetearem (cf. Plutarco, Mor. 291D = Quaestiones Graecae 18); e a magnanimidade de Címon, conforme no-la descrevem Teopompo, no fr. 89, 135 da Pbillipica (= Athenaeus 12.532f-533c), Plutarco, Cim. 10.1-2, e Aristóteles, Ath. 27.3. Nos testemunhos relativos ao patrono e aristocrata Címon ou no depoimento de Isócrates no Areopagiticus, não se verifica qualquer relação de clientela entre aristocracia e poetas. É, por conseguinte, ainda no âmbito da hospitalidade que se devem entender os convites endereçados por Arquelau, rei da Macedónia no fim do séc. V a.C., a Ágaton, Timóteo e Eurípides, no sentido de frequentarem a sua corte. Além disso, constituíam os festivais musicais e as comissões para a decoração de templos e outras obras de arte, bons pretextos para o acolhimento dado a artistas, e não rara era a presença de professores e filósofos (p. ex., sofistas) nas casas de ricos cidadãos atenienses. Em 16 (Xápıtes ทे l'́pov), tece o sujeito poético de Teócrito considerações sobre o dever dos jograis de cantarem os mortais, sobre a dificuldade contemporânea de os poetas encontrarem patronos, sobre a imortalidade que a poesia concede a quem a patrocina, sobre o facto de Hierão constituir uma exceção dentro dos patronos e necessitar do sujeito poético de Teócrito para entoar os seus feitos. No poema, ainda se formulam votos de que Hierão consiga expulsar da Sicília os Cartagineses, e se manifesta o anseio de convite de Hierão para celebrar as suas vitórias. É, conforme se depreende do idílio, ainda de hospitalidade que Teócrito necessita para entoar os feitos de Hierão, uma vez que a forma pelates, que, em Platão, Euthphr. 4C, ocorre na aceção de 'aqueles que se aproximam de outro por proteção', ainda se não regista como equivalente de clientes (cf. Millett 1989 21)

${ }^{18}$ Iddeng 2000 119. Em estudo de 1982, já havia Saller identificado três traços característicos de uma relação patrono - cliente, que recuperou em 1989 49: "First, it involves the reciprocal exchange of goods and services. Secondly, to distinguish it from a commercial transaction in the marketplace, the relationship must be a personal one of some duration. Thirdly, it must be asymmetrical, in the sense that the two parties are of unequal status and offer different kinds of goods and services in the exchange - a quality which sets patronage off from friendship between equals.»

${ }^{19}$ Rocha-Pereira 2009 230-1. A investigadora ainda alude a Epod. 1.5-6 e a Carm. 2.17, onde o sujeito poético horaciano afirma que, sem Mecenas, a sua vida nada significaria e que lhe não deseja sobreviver; à mútua formulação e aceitação de convites para jantar e aos jantares 
Em contraste com o desencanto decorrente da governação de Cláudio, afirma o narrador da Diui Claudii Apocolocyntosis, por meio de fraseologia que claramente remete para o quinquennium Neronis, que pretende registar o sucedido no céu a treze de outubro, initio saeculi felicissimi (1.1.1); e, por um lado, caricatura a deformidade física e critica os vícios de Cláudio, e, por outro, a Apolo compara Nero (4.1.9 e 23s. Cf. Cl. 2.1.3).

Com Townend, já Courtney admitiu, em comentário a Juvenal 7, a possibilidade de a sequência de profissões que necessitam do apoio de um patrono [poetas (1-35), historiadores (98-104), advogados (105-149), retóricos (150-214) e gramáticos (215-243)] inverter a que Suetónio, em De uiris illustribus, apresentara: gramáticos, retóricos, oradores, historiadores e poetas. ${ }^{20} \mathrm{O}$ segundo investigador ainda observou que já Marcial tinha retratado as miseráveis condições que em Roma se ofereciam a poetas e advogados (3.38), a gramáticos, retóricos e poetas, em contraste com as regalias de citaredos, flautistas e pregoeiros (5.56, cf. 3.4.8), e a poetas e advogados, em contraste com os privilégios dos pregoeiros (6.8). Apesar disso, das críticas dirigidas aos ricos, de uma ou outra advertência a algum cliens, e de máximas do tipo: quas dederis solas semper habebis opes (5.42.8) - será abusivo, conforme sustentou Baptista, ver em Marcial «um reivindicativo de uma classe» ${ }^{21}$, porquanto, como notara Garrido-Hory referida por Baptista, o sujeito poético de Marcial personaliza as situações. É em nome de intelectuais e autores de obras (studiorum 7.1), pelo contrário, que o sujeito poético de Juvenal 7 - diferentemente do de Teócrito 16 - deposita esperanças apenas num César que provavelmente coincidirá com Adriano, e não com Trajano.

frugais na casa de Horácio ( $S$. 1.6 .47 e 2.7.32-35); à independência do poeta ( $E p$. 1.1.94105 e 1.7.14-28); à renitência em tratar os grandes temas romanos (Carm. 2.12 e, a propósito da incapacidade de elogiar devidamente Agripa, 1.6); ao facto de, sob os efeitos de Baco, se propor o sujeito poético horaciano celebrar Augusto (Carm.3.25), e de este não apreciar elogios despropositados (S. 2.1.18-20).

${ }^{20}$ Courtney 1980 349-350.

${ }^{21}$ Baptista 2009 529. Ao afirmar que "não existe em todos os epigramas uma real força censuradora e moralizadora imbuída de revolta ou de profunda indignação pelas injustiças praticadas", parece a perspetiva da investigadora ir ao encontro da de Brandão 1998 141-2: "O poeta sabe que tem na sua mão uma arma terrível e temida, mas fazer uso dela não convém aos seus objetivos literários. Prefere usar inocuos sales, e assim consegue atingir um duplo objetivo: parcere personis, dicere de uitiis." O investigador ainda observa: "Se o próprio Marcial neutraliza uma arma que poderia ser geradora de desconfiança e inimizade, restam-lhe dois caminhos: o da glorificação através da menção das pessoas que o merecem - e Marcial confessa que isso lhe agrada - ou a omissão, condenando o interessado ao esquecimento eterno....." - no que parece coincidir com Pimentel 1993 429: "Mais que os amigos, é sobretudo quem é influente que o poeta evoca ou a quem se dirige. É a forma de atrair sobre si a atenção desses vultos proeminentes mas também de se aproximar mais e tanto quanto lhe for possível do(s) Imperador(es), topo de uma pirâmide que o poeta respeita e ajuda a construir e divulgar, em que a base não é mais que pano de fundo para realçar a grandiosidade do que se passa à boca de cena.” 
Se, na Grécia, era de hospitalidade que os poetas necessitavam para celebrarem quem lhes proporcionasse esse tipo de assistência, não se revelam tão específicas e exigentes as necessidades dos intelectuais latinos que, conforme se depreende de 7.3-12, reclamavam uma morada mais condigna do que um pequeno balneário em Gábios ou uma padaria em Roma, e algum sustento para não terem de exercer ofícios como o de pregoeiro ou o de vendedor em hasta pública. Dos valores morais da classe que o sujeito poético procura representar dão conta os versos 13-16, ao afirmarem que os referidos ofícios sempre são melhores do que a prestação de falsos testemunhos, como faziam ricos e influentes libertos provenientes da Ásia, da Capadócia, da Bitínia e da Gália.

Em 1.95-126 e como triste sinal dos tempos, já o sujeito poético considerara a apertada competição de uma multidão de togados por uma insignificante espórtula: eram indivíduos que se diziam descendentes de Troianos e ocupavam cargos públicos outrora prestigiados, como o de pretor ou o de tribuno; era um oriental, descendente de escravos, a quem uns quatrocentos mil provenientes de rendas de cinco lojas granjearam o estatuto de eques, e que lhes não reconhecia qualquer tipo de primazia; eram magistrados que dela não tinham tanta necessidade quanto os comites do sujeito poético que dela pagavam a toga, calçado, o pão e o fogo para se aquecerem; era a fileira de liteiras que se perfilava para recolher o donativo; era a mulher que, convalescente ou grávida, seguia o marido; era quem, para passar à frente dos demais, chamava por uma Gala que pretensamente estava a dormir, mas ao cabo se não encontrava na liteira vazia e cerrada.

Razões de queixa dos ricos e inseguranças relativamente às exigências do público romano, se o sujeito poético de Marcial respetivamente as tinha e manifestava, ${ }^{22}$ de igual sorte se encontram na sátira de Juvenal, embora

${ }^{22}$ Ao dirigir-se ao livro, escreve, com efeito, o sujeito poético de Marcial 1.3.3: Nescis, heu, nescis dominae fastidia Romae: / crede Mibi, nimium Martia turba sapit. "Desconheces, pobre de ti, os desdéns da Roma soberana: / acredita em mim, a turba de Marte tem um paladar assaz difícil." (Versão latina de Shackleton Bailey 1990 15, trad. de J. L. Brandão em Pimentel et al 2000 51.) Ora é Cândido quem, apesar das promessas de apoio se a desgraça se abater sobre o sujeito poético, com este não partilhará os bens se um deus o beneficiar (2.24); ora é Sexto, um usurário, que, para se esquivar a solicitações do sujeito poético, murmura, de forma audível para este, as suas próprias dívidas, e não deseja a amizade do referido sujeito poético, mas por este ser cortejado $(2.44,2.55)$; ora são os amigos ricos que se encolerizam para não terem de ser generosos (3.37 e 12.13); ora é Telesino que se julga generoso por emprestar, em vez de dar, e, ao cabo, só está interessado no campo de Marcial (3.41 e 12.25); ora é Póstumo que, depois de ter enriquecido, se esqueceu do sujeito poético (4.40); ora é Marco que, em contraste com Orestes e Pílades, só proporciona a Marcial o que para si próprio não tem utilidade (6.11); ora é Febo que demora dez dias a responder a um pedido de Marcial de dez sestércios (6.20); ora é Bácara cujas manifestações de disponibilidade para ajudar Marcial se não traduzem em apoio concreto (7.92); ora é a amargura de Atenágoras que o faz esquecer de enviar presentes ao 
muitas de natureza diversa: se, em 1.95-98, lamentara a instância de enunciação o apertado controlo exercido pelos patronos na distribuição de minguada espórtula, a fim de evitarem que alguém se fizesse passar por quem não era, já, em 7.23-35, adverte Telesino de que o melhor será queimar as folhas de pergaminho e quebrar a pena, pois um rico avarento não sabe apreciar senão o talento, e, transcorrida a idade de suportar mares, elmos ou enxadas, atinge uma velhice que se renega a si mesma e a Terpsícore; em 3638, de que, para lhe não dar nada, o próprio patrono se porá a fazer versos, com veleidades de rivalizar com Homero; em 35-44, das técnicas usadas pelo patrono para sabotar os recitais do cliente, nomeadamente a cedência de um espaço sem condições, com paredes manchadas de humidade, gonzos de portas a ranger e ruidosos libertos nas últimas filas; em 45-47, de que patrono algum o reembolsará dos gastos com assentos, com estrados construídos sobre madeiros de aluguer, ou com as cadeiras de uma orquestra. Em 1.128146, havia a instância de enunciação descrito um programa que se iniciava com a salutatio matinal, continuava com um passeio de patronos e clientes pelo foro, e, em vez de terminar com o aguardado convite dos primeiros aos segundos para jantar, resultava na desistência e no abandono, por parte dos clientes, dos átrios, sem dinheiro para as couves e o fogo, enquanto em baixelas elegantes, grandes e muito antigas, se banqueteavam os patronos com o que de mais requintado existia no mar e nos montes, e, devorados os patrimónios numa só mesa, depressa se transformavam em parasitas, ou, consumidos javalis inteiros e pavões, eram vítimas de indigestão, que também poderia decorrer do banho que tomavam a seguir ao jantar (cf. Pérsio 3.98106, e Celso 2.17.2). Em Juvenal 7.74-78, é Numitor quem, qual Lupo de Marcial 9.2, apesar de nada ter para dar a um amigo, oferece presentes a uma mulher, neste caso Quintila, e compra um leão que com carne terá de alimentar.

Numa espécie de balanço, poetas como Rubreno Lapa, cujo Atreu obriga a empenhar as tigelas e o manto (7.71-73), ou Serrano e Saleio Basso, a quem mais não resta do que uma grande glória (80-81), ou o próprio Estácio, cujo sucesso de umas leituras públicas da Thebais não obstam a que, para saciar a fome, tenha de vender ao cantor Páris as primícias da sua Agave (82-87), são postos ao lado de um Horácio, que só depois de bem jantar é que grita “Evohé!” (62; cf. Carm. 2.19.5 e 7), ou de um Virgílio, cuja Fúria, se o poeta não tivesse um pequeno escravo e uma morada condigna, teria perdido todas

sujeito poético e, deste modo, lhe causa igual amargor (8.41); ora é Postumiano, cujos presentes vão emagrecendo com o passar dos anos (8.71); ora é o sujeito que não vem a Roma para não ter de beber a zurrapa que para lá envia (10.36); ora é Cota que bebe os melhores vinhos e ao sujeito poético oferece os piores, embora com a possibilidade de serem servidos em taças de ouro (10.49); ora é Labulo cujos presentes não fazem dele mais do que o melhor dos avaros (12.36). 
as serpentes da coma e cuja tuba teria emudecido (69-71).

Em Lucílio e, como se viu, Horácio, pressentia-se a resposta dos respetivos patronos, traduzida em amizade e generosidade, e, simultaneamente, liam-se manifestações, por parte dos sujeitos poéticos, de emancipação e independência relativamente ao poder político e a modelos consagrados. O sujeito poético de Marcial também reflete o bom acolhimento que a sua pessoa e a sua poesia encontraram junto de determinados amigos, bem como a concessão por Domiciano do ius trium liberorum (2.91.5). Enquanto a instância de enunciação do poeta de Bílbilis alude aos dotes oratórios do amigo Juvenal (facundo 7.91.1) e o descreve como um hético cliens que, em 101 d.C., vagueava pela barulhenta Subura e pela colina de Diana, suava a toga pelas soleiras dos poderosos e errava no Célio maior e no menor (12.18.1-6) - não dedicou a de Juvenal as suas palavras a qualquer patrono, e deu a entender que tinha onde ficar na Aquino natal (3.319) e, cerca de vinte anos depois do testemunho de Marcial, casa na capital do Império (11.171 e 11.190), que parece ter sido uma herança familiar, com muitos criados (12.83-90), e uma propriedade no Tíbur (11.65), que abastecia de escravos a casa romana (11.151ss.). ${ }^{23}$

Mas, além de o passo apenas ecoar a esperança do sujeito poético no apoio do imperador e de se não vislumbrar qualquer vestígio de uma resposta mais palpável de Adriano a estas solicitações, não se pode deixar de notar uma certa diferença - que se não aproxima sequer de incompatibilidade - entre o retrato que Marcial faz de Juvenal, que põe em relevo as dificuldades do satírico e leva Courtney a reiterar a pobreza do poeta, e Socas a descrevê-lo como inquilinus em Roma ${ }^{24}$ e o que o sujeito poético, apesar das razões de queixa da Subura (Juvenal 3.5), sugere sobre si próprio, e, apesar de tudo, leva Braund a admitir a possibilidade de ele ser "of relatively high social status, like Lucilius and Persius" 25 , e, nessa medida, a distanciá-lo de alguns colegas de profissão que, de acordo com a sátira analisada, viviam com maiores dificuldades. ${ }^{26}$

\section{Os objetos imitados}

Antes de, na esteira de Platão, refletir sobre a importância do modo de imitação na distinção das diversas artes (Po. 3.1448a19-24), referiu o Estagirita a dos meios e dos objetos imitados na discriminação das diferentes espécies literárias (1.1447a16-18), e, ao considerar posteriormente e mais de

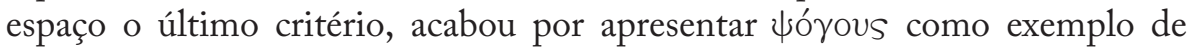
modalidade cultivada por autores mais vulgares, que imitaram ações de homens

\footnotetext{
${ }^{23}$ Courtney 1980 9, Socas 1996 9-10, Braund 1996 15-16.

${ }^{24}$ Courtney 19803 e 9, e Socas 199610.

${ }^{25}$ Braund 199616.

${ }^{26}$ Else 1967135 e 140, Lucas 196875 ad 48b27.
} 
vis (4.1448b25-27). Else traduz a forma por 'invectives' e, em comentário, observa que "no longer designates the first low-class poems, but the primitive

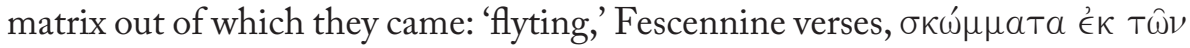

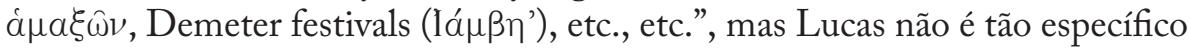
e cuida tratar-se de "songs or poems of abuse" 27.

Em comentário à Fescennina.... licentia horaciana de Ep. 2.1.145, admitiu Rudd a possibilidade de a palavra se relacionar com a cidade etrusca de Fescennium (cf. Sérvio in Aen. 7.695, e Porfírio) ou, na designação de Plínio, Nat. 3.52, Fescennia; ou, em alternativa, com o fascinum, ora na aceção de 'fascínio' e 'mau-olhado' que por meio de versos se lançava às pessoas, ora, conforme se depreende da relação que Aristóteles, em Po. 4.1449a4, estabelece entre os í $\alpha \mu \beta o l$, os cantos fálicos e a comédia, na de emblema fálico que se usava em volta do pescoço para proteção contra o mau-olhado. ${ }^{28}$

Quer se trate de injúrias soltas sob a forma de versos ou simples gracejos, quer se aluda a canções ou poemas de crítica, importa notar a presença da invetiva enquanto denominador comum à comédia, que justifica, na tripartida perspetiva aristotélica, o tratamento por parte de ambas as espécies de pessoas inferiores ao comum dos mortais. Embora Sousa tenha traduzido a forma por "sátiras", não se deve confundir a espécie em apreço com a sátira latina que, no dizer de Quintiliano, Inst. 10.1.9, era toda romana (tota nostra est) e etimologicamente se relacionava com o feminino do adjetivo satur 'cheio', que, por sua vez, se empregava para caracterizar uma lanx repleta de uma grande variedade de primícias que se ofereciam à divindade.

Quer isto dizer que, tão importante quanto a invetiva que presidia também à Comédia Antiga, era, no referido género e na sátira latina, uma polifonia para utilizar terminologia Bakhtiniana - que misturava géneros no propósito de, em contraste com a condensação aristotélica do ser humano em uma ou duas emoções como o riso ou o temor e a compaixão, revelar o homem em toda a sua complexidade. Da conjugação da distinção aristotélica entre História e ficção com a paródia que na Diui Claudii Apocolocyntosis se faz dos proémios das obras historiográficas, ou com a frase res uera agitur, de Juvenal 4.34, a propósito de uma reunião do senado por causa de um rodovalho, depreende-se que, apesar de "extramural" e, por conseguinte, contrastante com a "intramural" paródia, não coincide o objeto da sátira com o da historiografia. Mas quando o narrador das Verae Historiae de Luciano diz que, ao contrário de Ulisses que só contara patranhas sob aparência de verdades, tudo quanto vai dizer é mentira, parece querer deixar-nos a impressão de Que nos seus dialogi nem tudo é convenção estética.

\footnotetext{
${ }^{27}$ Else 1967135 e 140, Lucas 196875 ad 48b27.

${ }^{28}$ Rudd 198999.
} 
Se é precisamente algures, no espaço que fica entre estes dois extremos, que se deve situar tanto o terenciano bumani nil alienum puto (Hau. 77) quanto o hominem pagina nostra sapit de Marcial 10.4.10, já no tocante ao manifesto programático de Juvenal (1.79-89) maiores dúvidas se têm levantado.

\author{
Si natura negat, facit indignatio uersum \\ qualemcumque potest, quales ego uel Cluuienus. \\ Ex quo Deucalion nimbis tollentibus aequor \\ nauigio montem ascendit sortesque poposcit \\ paulatimque anima caluerunt mollia saxa \\ et maribus nudas ostendit Pyrrha puellas, \\ quidquid agunt homines, uotum, timor, ira, uoluptas, \\ gaudia, discursus, nostri farrago libelli est. \\ Et quando uberior uitiorum copia? Quando \\ maior auaritiae patuit sinus? Alea quando \\ hos animos?
}

"Se a natureza se recusa, faz a indignação os versos, conforme puder, conforme os faço eu ou Cluvieno. Desde que Deucalião, ao levantar nuvens o mar, de barco subiu a um monte e consultou os oráculos e aos poucos se foram do sopro vital aquecendo amolecidas pedras e aos varões mostrou Pirra nuas virgens, tudo quanto têm feito os homens - votos, temor, cólera, volúpia, alegrias, andanças - é forragem para o nosso livrinho. E quando foi mais fecunda a abundância de vícios? Quando se mostrou mais aberto o bolso da cupidez? Os dados, quando dominaram tanto estes ânimos?”

Depois de ter desvalorizado o depoimento de Varrão, $R$. 1.31.4-5, que definia a forragem (ocinum farraginem) como uma mistura de cevada, ervilhacas e outras leguminosas ainda verdes da pastagem (sata admixta hordeum et uicia et legumina pabuli causa uiride), e de Festo, p. 91 M., que a dizia feita ex pluribus satis, aduziu Powell a ocorrência do termo em Pérsio 5.77, com valor semelhante ao de pabulum, para demonstrar que "any idea of mixture or hotchpotch seems very subordinate" e que, neste cotexto e na maior parte daqueles em que aparecia, a palavra mais não significava do que 'fodder' no sentido restrito de "food for animals" ${ }^{29}$ Embora se possa admitir a possibilidade de a forragem ser maioritariamente composta por uma determinada espécie de cereal, a ausência de escolha no momento de a preparar possibilita a entrada de outras plantas na composição do referido alimento animal.

\footnotetext{
${ }^{29}$ Powell 1987255.
} 
A interpretação de Powell é, no entanto, a que melhor se coaduna com a ideia posterior e convincentemente demonstrada de que o alvo do sujeito poético de Juvenal não é todo o passado, nem, ao cabo, as personagens do passado referidas em 170-1, mas apenas determinados aspetos do comportamento humano que no presente assumem maiores proporções, nomeadamente o vício (87-9) que, de acordo com 79-80 e em caso de incapacidade do engenho e da arte do poeta, provocará uma indignação criadora de versos, e, segundo 147-9, não será maior no futuro do que no presente. ${ }^{30}$

Embora a reflexão de Powell vá ao encontro do que antes se disse sobre o alvo da historiografia e o da sátira, a verdade é que, em edição crítica da referida composição, continuou Braund a ver em farrago "a sophisticated allusion to the etymological derivation of the word satura itself: just as farrago is literally 'mixed fodder', so satura is probably originally mixed first fruits offered to a deity...." 31

É certo que o passo de Juvenal admite a possibilidade de a indignatio se sobrepor à natura na elaboração dos versos; que com perspicácia observou Braund que, em 84 (maribus nudas ostendit Pyrrba puellas), se distancia o sujeito poético do registo épico ao retratar Pirra "as a madam of a brothel, displaying her girls to customers"32; que o timor, a ira e a uoluptas eram sobretudo encaradas como paixões; que, conforme sustentam Courtney e Braund, discursus pode ocorrer na acepção de 'aimless' ou 'futile activity'; e que as interrogativas retóricas finais realçam a invulgar dimensão, na época do sujeito poético, do vício em geral, e, em particular, da avareza e do jogo - mas, além de o conceito de uotum poder ocorrer no âmbito da verdadeira e sentida deuotio, e de gaudium se registar, na literatura latina anterior, ora em sentido depreciativo e popular (cf. Séneca, Dial. 10.17.3, Ep. 23.5, 59.2-3 e 14-18, 98.1), ora como resultado da virtude (Séneca, Ep. 27.3-4, 71.5, 74.29, 81.21), da nobre conduta (Séneca, Ep. 76.28), da sabedoria (Ep. 59.14 e 16, 72.4 e 8-9, Dial. 2.9.3, 7.4.4), da descoberta da verdade (Séneca, Dial. 7.4.5) e da vitória sobre medos e prazeres (Séneca, Dial. 7.3.4), importa não esquecer os casos em que Juvenal faz contrapontos positivos aos vícios que refere. Quer isto dizer que a melhor solução é a que passa por um compromisso entre o reconhecimento do predomínio da dimensão crítica e a presença quer de uma recordação explícita dos bons exemplos do passado, quer de uma implícita subjacente, p. ex., a processos paródicos.

O passo juvenalesco ainda insinua, por um lado, uma mistura de affectus que o sujeito poético sugere inerentes à condição humana (temor, cólera, volúpia

\footnotetext{
${ }^{30}$ Powell 1987255.

${ }^{31}$ Braund 199696.

32 Braund 199695.
} 
e cupidez), com velhas práticas que os podem traduzir, como a prostituição sugerida pela fraseologia, eventualmente certo tipo de votos, andanças e o jogo, e com o que são suscetíveis de proporcionar (alegrias enganadoras), e, por outro, o recurso a um critério quantitativo e diacronicamente comparativo, já referido por Powell, para justificar a indignatio do sujeito poético.

Em comentário aos versos de Juvenal citados, notou Courtney que, como em 15.30, faz o sujeito poético remontar a Pirra o início da humanidade e, com Propércio 2.32.53-4, da corrupção moral, ${ }^{33}$ mas, ao indagar da antiguidade da mulher enquanto motivo cómico e satírico, não deixou M. F. Silva de recordar Hesíodo, Th. 600-612 e Op. 57-82, onde Pandora aparecia como um presente envenenado concedido por Zeus ao homem; Arquíloco, que se situava na mesma linha; Semónides de Amorgos, que, no fr. 7 West, catalogava os vícios femininos; o cómico Susárion (fr. $1 \mathrm{~K}$ ) e, entre outros passos de Aristófanes, Lys. 1039, onde a mulher aparecia como um mal necessário. ${ }^{34} \mathrm{Na}$ Comédia Antiga, três eram, segundo a referida investigadora, as principais críticas dirigidas ao género feminino: o excessivo gosto por bebida, a prática de trair os maridos e uma incansável loquacidade. Mas quando se considera a presença dos referidos tópicos na obra de Juvenal, facilmente se percebe que não caracterizam apenas o comportamento das mulheres, mas além de poderem ocorrer de forma superlativada nos homens, muitas vezes adquirem nestes uma dimensão pública e política que se não encontra na invetiva dirigida ao género feminino.

O primeiro dos referidos vícios, intimamente associado à luxúria e à depravação e filtrado pela tradição retórica e pela elegíaca, ocorre como justificação para o segundo na mulher a quem o vinho não permite a distinção entre um membro e uma mente, isto é, na que, por entre uma e outra ostra, tanto se entrega à fellatio como conversa com algum amante; em Maura, que, além de constituir um exemplo do caso anterior, ainda para com a irmã, durante a noite, junto do altar da Vergonha para nele urinar (6.301-313); em Saufeia e Medulina que, a desdizerem das respetivas estirpes, competem, por uma coroa, com dançarinas profissionais, e, excitadas pelo vinho e enquanto ménades de Priapo, aproveitam os mistérios da Boa Deusa para traírem os maridos com amantes expressamente chamados para o efeito, e, em caso de indisponibilidade destes ou de escravos, um aguadeiro, ou, dada a falta de homens e em derradeiro recurso, com asnos (6.314-334; v., sobre a ocasião considerada, Ovídio, Ars 3.637-8). Sôfrega é ainda a sede da mulher que, além de punir severamente quantos the imploram piedade, nomeadamente o dono

${ }^{33}$ Courtney 1980 102. V. ainda as afinidades entre a paródia do registo épico em Horácio, S. 2.1.13-15, e Juvenal 1.52-4 e 81-4.

${ }^{34}$ Silva 1991 209-10. 
do cão que a perturbara e o próprio animal, e de se entregar a massagens noturnas, enquanto os convivas, à espera, morrem de fome e de sede, chega à mesa com vontade de beber o enóforo que encerra o conteúdo de uma urna cheia e do qual retira um pouco para lhe abrir o apetite e lhe limpar o estômago, e passa a refeição a comer, a beber e a vomitar (6.413-433).

De igual sorte, se, na referência do sujeito poético a patronos que devoram verdadeiras fortunas à mesa (1.132-146), não será difícil imaginar a presença e o consumo abundantes de vinho, aparece a referida suspeita confirmada em 5.24-79, onde se considera a diferença de qualidade de recipientes usados e de vinhos bebidos por senhor e cliente, e mais especificamente em 5.5.49, onde o estômago do patrono aparece a ferver em vinho e comida.

Quanto ao adultério, decorrente da falta de pudor e igualmente considerado por elegíacos e retóricos, tanto o comete Cíntia, que serve de inspiração ao sujeito poético de Propércio (6.7), ou Lésbia, que inspira o de Catulo (6.7-8), ou Hibérnia, que se não satisfaz com um só homem (6.53-56); como o deseja Túcia, que perde a razão com os meneios de Batilo a representar Leda (6.6364), Apula, que pelo referido ator suspira, Tímele, que lhe presta silenciosa e religiosa atenção (6.65-66); por ele aspiram as que, entre os jogos megalenses e os plebeus, desejam brincar com a máscara, o tirso e as cuecas de Ácio (6.6770); Élia que, apesar de pobre, está apaixonada pelo comediante Úrbico (6.7173); arruína a voz de Crisógono (6.73-74); é sugerido pelo regozijo de Hispula com um ator trágico (6.74-75); leva Épia a abandonar o marido, um senador, para seguir um gladiador decrépito (6.60-113); Censénia a precaver-se com dote de um milhão de sestércios, para garantir uma liberdade que, diante do marido, lhe permite comunicar com outros por sinais e responder a bilhetes (6.136-141); é cometido pela mulher que, consciente do incondicional amor do marido, se comporta como uma tirana que ainda se encanta com um velho amigo do primeiro, impõe ao consorte a inclusão de um rival no testamento, e passa o tempo em partidas para aventuras amorosas e desencantados regressos à segurança do lar (6.214-230); pela mulher a quem a mãe ensina a responder docemente aos bilhetes de um sedutor e cuja mãe se encarrega de ludibriar os guardas ou com dinheiro os corromper, e, por meio de simulação de doença, cria condições para que o amante da filha se retire discretamente (6.233-241); pela que, para ocultar a culpa de bilhetes e cartas clandestinas e de qualquer relação extraconjugal com algum escravo ou cavaleiro, simula ciúme e recrimina o marido porque supostamente a trai com algum rapaz ou alguma amante (6.268-285); pela que a efeminados cunnilingi permite as maiores extravagâncias e trata da forma mais requintada, por eles suspira constantemente, segue seus conselhos e com eles trai o marido (6.365; cf. Marcial 12.38); pela que se envolve com eunucos (6.366-378; cf. Marcial 6.2.6 e 6.67); pela que prefere cantores, e, mais concretamente, pela dos Lâmias e 
da casa de Ápio que com pão e vinho consulta Jano e Vesta para saber se pode Polião esperar de sua cítara a vitória no concurso capitolino (6.379-397); pela mulher rica, que usa colar de esmeraldas, grandes argolas às orelhas, cuja cara aparece inchada com uma película de miolo de pão, ou exala o odor da pomada Popeia, cuja pegajosa pele recebe os beijos do marido e só se lava para o amante, que aos amantes seduz com essências provenientes da Índia, se banha em leite de burra, e cujo rosto, com todos aqueles ingredientes e cataplasmas de farinha húmida, mais parece uma úlcera (6.456-473); pela que, se o marido lhe vira as costas de noite, castiga a administradora; se o cabeleireiro despe a bata, castiga o lacaio por ter chegado atrasado; distribui férulas, açoites e correias pelos serviçais; contrata verdugos a soldo; se pinta, escuta as amigas, examina a borda de ouro de um vestido bordado, relê de soslaio as linhas de um diário, enquanto alguém é castigado até faltarem as forças ao algoz; castiga a pobre Psécade se um cabelo frisado fica mais alto, tem ainda outra escrava para lhe tratar do cabelo e várias para lhe darem as respetivas opiniões; vista por trás, parece outra, e, pela frente, uma Andrómaca; vive como se mais não fosse do que vizinha do seu marido cujos amigos e escravos lhe merecem desprezo e ódio e é um grande peso no orçamento do último (6.474-511); pela mulher que por promessas de ternos amantes consulta um arúspice da Arménia ou de Comagena (6.548-550); pela que, qual Tanaquil, consulta o astrólogo caldeu para saber se mais há-de seu amante viver do que ela (6.565568 ); e eventualmente pela que, com longo colar, indaga diante de palcos ou da colunata de golfinhos, se, abandonado o estalajadeiro, dará a sua mão a um vendedor de capotes (6.590-591).

Se, em 1.77-78, contara a instância de enunciação, entre os motivos de indignação, a nora gananciosa que se deixara seduzir pelo sogro, e a noiva infiel; e se, em 2.36-63, justificara Larónia, com o silêncio de uma jovem esposa e o envolvimento com um liberto numa espécie de ménage à trois, o facto de Histro ter passado a vida a oferecer, à cônjuge, pedras preciosas, e deixado um testamento repleto do nome do favorito - em 6.42, é o desejo de um moechorum notissimus, Ursídio, de encontrar uma mulher de costumes antigos para contrair matrimónio, que torna o sujeito poético ainda mais pessimista relativamente ao casamento enquanto instituição.

No tocante ao tema da loquacidade excessiva das mulheres, convém, desde já, enquadrar, no âmbito de uma discussão assaz antiga sobre a incompatibilidade entre a cultura grega e as ideias políticas e morais dos Romanos, o tratamento específico que o sujeito poético juvenalesco lhe dá. Em contraste com a Lucrécia descrita p. ex. em Tito Lívio 57.1-60.4, ou com a Cláudia de Bücheler, Carmina Epigraphica 52, era Semprónia, de acordo com o narrador salustiano (Cat. 25), «instruída em letras gregas e latinas, $<$ sabia $>$ tocar e dançar de forma mais elegante do que convém a uma mulher 
honesta, e muitas outras coisas que estão ao serviço da ostentação» (litteris Graecis Latinis docta, psallere [et] saltare elegantius quam necesse est probae, multa alia, quae instrumenta luxuriae sunt). De igual sorte, critica a instância de enunciação juvenalesca a mulher que se não julga bela se, nascida na Toscana, se não comportar como grega, ou se, de Sulmona, se não fizer uma autêntica ateniense; a mania do grego nas jovens e - vergonha das vergonhas - na mulher de oitenta e seis anos, e até nos momentos mais íntimos (6.184-199); a mulher que, à mesa, cita Virgílio, se compadece de Dido na hora da morte, faz comparações entre Virgílio e Homero, vence retóricos e professores, não deixa falar público, advogados, pregoeiros ou qualquer outra mulher, se pronuncia de forma tão estridente que mais parece o bater de bacias e sinetas, e dispensa trombetas e bronzes para espantar o animal que nos eclipses rói a lua, a mesma que se dá ares de ciência e eloquência, domina vários tipos de registo ou estilos, introduz na frase redonda tortuosos entimemas, conhece todo o tipo de argumentos e, com profundidade, a gramática de Palémon, observa sempre as regras e a norma linguísticas, aprecia o antigo, sabe versos que o sujeito poético desconhece, corrige os lapsos gramaticais das amigas, e, segundo o sujeito poético, devia ser obrigada a arregaçar a túnica até meio da perna, matar um porco em honra de Silvano, tomar banho por um quarto de asse e suportar um marido que só dissesse barbarismos (6.434-455).

Embora a informação veiculada pelo narrador da Carta guia de casados (1651 f. 82 rosto), de D. Francisco Manuel de Melo - de que tinha ouvido «a hum chapado recoveiro [....], que Deos o guardasse de mula que faz him, e de mulher que sabe latim» ${ }^{35}-$, não ateste apenas a grande fortuna do tópico em análise mas também a de Juvenal 6, a verdade é que, conforme se depreende p. ex. de Séneca, Apoc. 1.5.2-4, a obsessão com o grego era extensiva ao género masculino, mais propriamente ao imperador Cláudio. ${ }^{36}$ Mas a referida vertente

${ }^{35}$ Sobre o conhecimento que Luísa Sigeia, precetora da infanta D. Maria (filha de D. Manuel) e Joana Vaz tinham do latim, e acerca de outras variantes do provérbio, v. Conceição Flores 201021.

${ }^{36}$ E se o imperador falava grego de forma ininteligível, não era seguramente em obediência a qualquer imperativo do tipo do que posteriormente haveríamos de encontrar em Eça de Queirós, mais propriamente em $A$ correspondência de Fradique Mendes, 130-1: "Um homem só deve falar, com impecável segurança e pureza, a língua da sua terra: - todas as outras as deve falar mal, orgulhosamente mal, com aquele acento chato e falso que denuncia logo o estrangeiro. $\mathrm{Na}$ língua verdadeiramente reside a nacionalidade; - e quem for possuindo com crescente perfeição os idiomas da Europa vai gradualmente sofrendo uma desnacionalização. Não há já para ele o especial e exclusivo encanto da fala materna com as suas influências afetivas, que o envolvem, o isolam das outras raças; e o cosmopolitismo do verbo irremediavelmente lhe dá o cosmopolitismo do carácter. Por isso o poliglota nunca é patriota. Com cada idioma alheio que assimila introduzem-se-lhe no organismo moral modos alheios de pensar, modos alheios de sentir. O seu patriotismo desaparece, diluído em estrangeirismo [....] Por outro lado, o esforço contínuo de um homem para se exprimir, com genuína e exata propriedade de construção e de 
da loquacidade, que a instância de enunciação diz característica do género feminino e decorrente da influência grega, acaba por se revelar relativamente inofensiva quando comparada com os demais recursos linguísticos de que se serviram os Gregos para conquistarem os Romanos.

Depois de afirmar que não sabe mentir, não é capaz de louvar e comprar um mau livro, nada percebe dos movimentos dos astros, não quer nem pode anunciar a morte de um pai e, entre outras atividades indignas, jamais inspecionou as vísceras de rãs (3.41-45), sustenta Umbrício que Roma é a cidade que mais agrada aos ricos dos quais, qual Eneias de Virgílio, $A$. 1.2, foge (quos praecipue fugam, 3.59), e declara: (3.60-61): Non possum ferre, Quirites, / graecam urbem; quamuis quota portio faecis Achaei? «Não posso suportar, Quirites, / uma Roma grega. De facto, que porção desta escória são os Aqueus?»

$\mathrm{E}$ dos Aqueus ainda realça a instância de enunciação, em toada irónica e desencantada, uma superioridade que, entre outras manifestações, se traduz em inteligência viva, ousadia desenfreada, eloquência volúvel e mais torrencial que a de Iseu, um retórico do norte da Síria (3.73-74); na capacidade de louvar a eloquência de um inculto, a cara de um amigo feio; de, à cerviz de Hércules, quando apartara Anteu da terra, comparar o colo descarnado de um indivíduo débil; de admirar uma voz que, em estridência, nem a do galo quando debica a galinha consegue exceder; de, em semelhantes lisonjas, ser bem mais convincente do que os Romanos; de interpretar como ninguém uma Taide, uma esposa, uma Dóris sem qualquer mantinho grego, e, ao cabo, qualquer papel feminino (3.86-97); de, em contraste com a reação normal de qualquer pessoa educada (cf. Cícero, Fam. 9.22.5, Marcial 12.40.3, Suetónio, Cl. 32), bater palmas e felicitar um amigo que bem arrotara, que com força urinara, e cujo bacio de ouro dera um traque quando se virara (3.104-108); ${ }^{37} \mathrm{de}$, como Públio Egnácio Célere fizera a seu patrono e aluno Bárea Sorano, recorrer à delação e à intriga, que fazem parte do seu código genético, para trair amizades (3.116-125; cf. Tácito, Ann. 16.32 e Hist. 4.40).

acento, em idiomas estranhos - isto é, o esforço para se confundir com gentes estranhas no que elas têm de essencialmente característico, o verbo - apaga nele toda a individualidade nativa. Ao fim de anos esse habilidoso, que chegou a falar absolutamente bem outras línguas além da sua, perdeu toda a originalidade de espírito - porque as suas ideias forçosamente devem ter a natureza incaracterística e neutra adaptadas às línguas mais opostas em carácter e génio. Devem, de facto, ser como aqueles «corpos de pobre», de que tão tristemente fala o povo - «que cabem bem na roupa de toda a gente».Além disso, o propósito de pronunciar com perfeição línguas estrangeiras constitui uma lamentável sabujice para com o estrangeiro. Há aí, diante dele, como o desejo servil de não sermos nós mesmos, de nos fundirmos nele, no que ele tem de mais seu, de mais próprio, o vocábulo. Ora isto é uma abdicação da dignidade nacional. Não, minha Senhora! Falemos nobremente mal, patrioticamente mal, as línguas dos outros!"O passo aparece comentado em Carlos Reis 20104.

${ }^{37}$ Sigo a interpretação de Braund 1996193. 
A adulação e a delação não aparecem explicitamente ligadas ao comportamento feminino, mas se a revelação de segredos e a difamação, intimamente associadas à segunda das referidas práticas linguísticas, são, de acordo com 9.112-117, características dos escravos que, desta forma e ébrios, se vingam dos golpes de correia ordenados ou ministrados pelos senhores, já, em 1.33-36, depois de se ter interrogado sobre quem poderia suportar tão perversa cidade (quis iniquae / tam patiens urbis, 1.30-31), havia a instância de enunciação justificado a sua indignação com uma liteira cheia do causídico Máton e com o delator que o seguia, era temido por Massa e adulado por Caro e Latino, e estava prontinho a rapinar o que restava de uma nobreza já bem roída (cito rapturus de nobilitate comesa / quod superest, 1.34-35).

Com base na hipertextualidade em geral e, em particular, no registo paródico, demonstrou recentemente Baines que, em Juvenal 3 e especialmente em 278-301, Umbrício aparece representado como um novo Eneias - o que torna a instância de enunciação um outro Virgílio -, que o pauper dos versos referidos é retratado em termos próximos dos de Eneias, Heitor e Príamo - o que faz de Umbrício outro Virgílio -, que o brutamontes do passo juvenalesco tem afinidades com Aquiles, Pirro e Tideu, e que Roma ora aparece como uma nova Troia ora como outra Tebas. ${ }^{38}$ É, por conseguinte, no âmbito de uma

${ }^{38}$ Baines 2003 220-34. A investigadora aduz, entre outros paralelos, a decisão de Umbrício de se retirar para Cumas (3.2), terra onde Dédalo havia caído (Virgílio, A. 6.14-19); as afinidades entre $A$. 1.2 e Juvenal 3.59, onde Eneias e Umbrício se dizem respetivamente fugitivos de uma terra invadida por Gregos; Juvenal 3.278-301, onde o pauper encontra um brutamontes que é semelhante ao melhor dos Aqueus (Aquiles); as confluências de Juvenal 3.194-9 e 212-14, onde se registam os motivos do incêndio e do pesar pela perda dos bens da casa em chamas, $\operatorname{com} A$. 2 e, em especial, 2.311s., onde Ucalegonte aparece como vítima do fogo que consome a sua habitação; a comparação entre a liteira de um rico e uma nau a romper por um mar de gente (Juvenal 3.240-44); o facto de Virgílio, A. 2.624-31, e Juvenal 3. 254-6 recorrerem à imagem da árvore, num caso derrubada e no outro a balançar num carro em movimento, para descreverem respetivamente a ruína de Troia e a de Roma; a representação, no acidente da rua, de um esmagamento em termos que fazem lembrar o do mineiro espanhol de Estácio, Theb. 6.880-6; os preparativos que, em Juvenal 3.261ss. e Homero, Il. 22.442-6, respetivamente fazem os escravos domésticos e Andrómaca para o funeral de uma das vítimas do esmagamento e para Heitor; a sugestão de que uma deslocação pelas ruas de Roma não é menos arriscada do que uma batalha com os Aqueus; a comparação entre a insónia do brutamontes, em Juvenal 3.278-80, e o pesar de Aquiles por Pátroclo em Il.24.9-12; a possibilidade de petulans (3.278), que Umbrício usa para caracterizar um brutamontes que não ataca quem se pode defender mas apenas um pauper indefeso (3.283ss.), nos remeter para a atitude, a facilidade e a humilhação com que Pirro, um jovem, trespassa um velho como Príamo (A. 2. 550-8, cf. Juvenal 10.267-70) que, em A. 2.506-11, havia vestido da armadura, ou para o ataque da garganta de Mezêncio à espada de Eneias em $A .10 .907$ s. (para a imagem, v. Lucano 7.533s., e Sílio Itálico 16.70s.); a hipótese de Pelidae de 3.283ss. se não referir a Aquiles mas a Pirro (cf. Virgílio, A. 2.263); a maturidade e a idade avançada de Umbrício (3.26-8 e124s.) e a ferocidade juvenil do brutamontes (3.282); as semelhanças entre a coccina laena (3.283: 'manto de púrpura') do rico que não é incomodado pelo brutamontes, e a laena de Eneias, que, segundo o narrador de $A .4 .262$, Tyrioque ardebat murice; entre o cortejo que acompanha a pessoa rica em 3.283-5 e o fúnebre de Palante, em $A .11 .94$, com 
mobilidade social, onde os ricos que se diziam descendentes dos Troianos, tudo gastavam em comida, bebida e outros vícios trazidos pelos gregos, e onde os estrangeiros, mercê de atividades que os Romanos tinham por indignas e da delação, faziam fortuna e conquistavam poder - que devemos situar, de um lado, com o brutamontes, os patronos e os magistrados anteriormente referidos, que se tornaram clientes; o que reclama responsabilidades militares incompatíveis com a dilapidação do património familiar em estrebarias e com amantes (1.60-61), e, do outro, um barbeiro que fez fortuna; um Crispino, proveniente do odiado Egito, que se permite todos os luxos (1.24-30); o delator que segue Máton; Tibério Júlio Alexandre, de origem judaica, apóstata, prefeito no Egito entre 66 e 70, participante nas campanhas judaicas de Tito em 70 e apoiante de Vespasiano, e que, além de poder urinar nas estátuas, ainda teria sido retratado numa inscrição que conteria os títulos de "Egípcio" e "Arabarca" (1.129-131).

Sustenta ainda Umbrício que os Gregos conjugavam a delação com uma lubricidade que nada tinha na conta de sagrado e, por conseguinte, não poupava mãe de família, filha virgem, noivo imberbe, filho até então intacto, ou, em último recurso, a avó de algum amigo (3.109-112). De igual sorte, apesar de justificar, com a imagem extremamente visual de Mévia, de seios desnudos e venábulo em punho, a caçar javalis, a opção pelo género cultivado por Lucílio (1.22-23); e de criticar, em 6.246-267, a atleta que, como a visada em Marcial 7.67, recorre a grossos mantos de púrpura de Tiro, designados pela forma grega endromidas, para se proteger de resfriados nos intervalos, e luta em escolas femininas com ringues de lama (ceroma) - não deixa instância de enunciação Juvenalesca de considerar da mais elementar justiça ripostar a fingidos Escauros (2.34-35), e, para ilustrar a sua tomada de posição e eventualmente com a discrepância entre as nove partes de prazer

as tochas $(A .11 .143 \mathrm{~s}$.); o recurso a registo semelhante ao de $A .5 .808-10$, onde Neptuno relata a sua intervenção no sentido de salvar Eneias das mãos de Aquiles, ou aos de Il. 334 e 20.97100 - onde Posídon e Eneias respetivamente reconhecem a superioridade guerreira de Aquiles - para descrever o recontro do pauper com o brutamontes; o facto de, como Eneias, perspetivar Umbrício a ascendência dos Gregos em termos de incompatibilidade pessoal (Juvenal 3.104-8); a natureza noturna do episódio entre o pauper e o brutamontes e da emboscada dos cinquenta homens de Etéocles a Tideu em Estácio, Th. 2.485-95; as perguntas de Aquiles, Palante, Tideu e do brutamontes, respetivamente em Il.21.150, A. 8.114, Theb. 2.535 e Juvenal 3.292, sobre a origem e identidade dos adversários; a ausência de resposta em Estácio, Theb. 2.536s., e Juvenal 3.295-7; o desafio do brutamontes, em Juvenal 3.290, e de Tideu, em Theb.2.547, aos adversários no sentido de os enfrentarem (cf. $A$. 10.308s., 11.282 e 12.887); a ocorrência de consistere, na aceção militar de "tomar posição", em Juvenal 3.296, Virgílio, A. 9.788s., e Estácio, Theb. 2.5835; a súplica dos vencidos em Juvenal 3.300 e Estácio, Theb. 2.647s.; as afinidades entre a onda de gente que, em Juvenal 3.243-5, impede Umbrício de avançar, e os carros que, em Estácio, Theb. 8.348-52, impedem a passagem a soldados apressados, como se, por trás, os puxassem os Dânaos. 
experimentadas por Tirésias enquanto mulher e a única como homem (cf. dupla referência ao mito: em 6.253-254 e 13.249) em mente, dá voz a Larónia que, em resposta a um efeminado que a criticara por se dedicar à prostituição, nota o olor a opobálsamo que do colo de seu detrator se desprende e indicia os beijos de um jovem; invoca a lei Escantínia, de 226 e reforçada por Domiciano, que punia o stuprum de menores do sexo masculino e de condição livre; e em contraste com a cumplicidade de efeminados, a quantidade de homens que trabalham a lã, em cestas cardadas transportam velos, se revelam mais destros que Penélope a usar a roca, que Aracne a tecer, e não ficam atrás da concubina que, sentada num tronco, se vê obrigada a fiar - sustenta que, entre as mulheres, não há caso algum de lesbianismo, que poucas são as que combatem, ou comem as almôndegas de carne que fazem parte da dieta de atletas (2.47-53). Depois de invetivar as mulheres que se dedicam a desportos geralmente praticados por homens e de recordar o testemunho de Tirésias, não deixa, de resto, a instância de enunciação de concluir, em 6.253-4, que, apesar de tudo, não desejam as referidas atletas abdicar da condição de mulher.

Apesar de uma intemporalidade subjacente ao manifesto poético transcrito, que, conforme se viu, de outro critério se não socorre que não seja o quantitativo para discriminar, dos vícios passados e futuros, os do presente; e de uma universalidade que, no tocante a grande parte dos vícios femininos considerados em Juvenal 6, não distingue, das cidades provinciais, a de Roma (cf. 6.1-59), não deixa a instância de enunciação de balizar a composição com os vícios e crimes de duas mulheres que deixaram marcas no Estado romano e na política imperial: depois de recordar, logo a seguir à secção introdutória de Juvenal 6 e de forma assaz pormenorizada, a entrega de Messalina à prostituição sob o falsum nomen de Licisca 'filha de cadela e lobo ou de loba e cão', e a exibição, no prostíbulo, do ventre que carregou Britânico, pergunta-se retoricamente a instância de enunciação se falará da carúncula negra da testa dos poldros - que era usada na sedução amorosa -, das fórmulas mágicas, do veneno que se prepara para o filho de um primeiro casamento (6.114-135). Para completar a estrutura circular da composição, dedica a instância de enunciação alguns versos às que, com filtros mágicos, enlouquecem os maridos (6.610-625), às que, como Medeia, Procne e Pôncia, envenenam os filhos, e às que, quais Danaides, Erifile ou Agripina, preparam ou dão a morte aos respetivos cônjuges (6.626-661). Importa, no entanto, notar que tanto aqui como em 1.69-72 se não verifica qualquer referência nominal a Agripina, mas apenas um alusão à rã usada por Locusta para envenenar Cláudio.

Dos comportamentos femininos considerados em Juvenal 6, o envenenamento é, de longe, o mais grave, mas, quando os vícios são comuns aos Romanos das mais diversas condições sociais, adquirem, quando praticados 
pelo imperador ou por pessoas que lhe estão próximas, uma dimensão mais universal, porquanto refletem o falhanço da missão civilizadora da urbe.

Embora as Eclogae, as Georgica e a Aeneis de Virgílio, e os Carmina de Horácio propagandeassem o regresso à austeridade e à frugalidade associadas ao tradicional minifúndio, não deixava Augusto, nos longos intervalos entre esporádicas e momentâneas recaídas republicanas, de diligenciar no sentido de revestir de mármore a Roma de tijolo que recebera, exposta, como se encontrava, a inundações e incêndios (Suetónio, Aug. 28).

Entre os motivos aduzidos por Umbrício para deixar Roma continuam a contar-se os incêndios e as derrocadas de telhados (3.6-8), que coexistem com mármores importados que não deixam sentir a presença da divindade nas águas do bosque de Egéria, e constituem uma ofensa à pedra esponjosa e vulcânica nativa (3.17-20). A saudosa recordação dos sãos costumes dos antepassados, que se regista na sátira menipeia desde pelo menos Varrão [Bimarcus, frg. XXV, 69 (63) Cèbe], coexiste com a paródia dos exageros dos laudatores temporum actorum (cf. Petrónio 44).

Além de ter cometido adultério e incesto com a sua sobrinha, Júlia, a quem obrigou a abortar, e de ter reforçado, enquanto censor perpetuus (84 d.C.), a legislação augustana contra a primeira das referidas práticas (2.2933), convocou Domiciano uma reunião do senado para decidir o que fazer com um rodovalho que não cabia em prato ou bandeja alguma das existentes no palácio. Quando se consideram as pessoas que faziam parte do conselho de Domiciano, o que se nota é que eram representantes, se não de todos, pelo menos de muitos dos vícios até aqui considerados, ou vítimas desses mesmos vícios: Víbio Prisco, bom conselheiro que nunca tinha conseguido falar livremente; Acílio Glabrião, que haveria de ver seu filho combater na arena e condenado à morte por Domiciano; Rúbrio Galo, que havia seduzido a imperatriz Domícia e, de acordo com a instância de enunciação, era mais indecente que um homossexual que escrevesse sátiras; Montano, cuja barriga denunciava grande gula; Crispino, que tresandava a amomo; Pompeio, descrito como um delator cruel; Cornélio Fusco, que preparava guerras entre os mármores da sua casa; o perigoso Lúcio Veientão e o mortífero Lúcio Catulo Messalino, que aparece descrito como um invisual que, voltado para a esquerda, elogiava o rodovalho que à sua direita se encontrava (sobre a deformidade física enquanto tema da crítica cínica, v., p. ex., o Cláudio da Diui Claudii Apocolocyntosis; ou Crítica da razão cínica de Peter Sloterdijk). Com base em credenciais como o conhecimento que Montano tinha da antiga luxúria do império, das madrugadas de Nero, onde sentira uma renovada fome e os pulmões a arderem de falerno, acabou por aceitar a sugestão do bon vivant no sentido de se forjar um recipiente adequado ao rodovalho (4.130139). Da importância do engano, do disfarce, da luxúria, das relações fúteis 
e do sacrilégio para a queda de Troia e de Roma, já Petrónio, no dizer de Zeitlin, havia tratado. ${ }^{39}$

Da conjugação da hipocrisia e da luxúria de Augusto e Domiciano com um Otão que, no dizer da instância de enunciação, não passava de um favorito que tinha num espelho o objeto mais valioso (2.99ss.), dificilmente poderia resultar outra coisa que não fosse uma Urbe cujo clima de impunidade incentivasse à extorsão e à saeuitia nas províncias (cf. exemplo de Mário Prisco em 2.11-12) ou que transformasse um arménio ingénuo, Zálaces, no mais efeminado dos efebos (2.166-170). Embora a crítica de Juvenal nos pareça, em muitos aspetos, intolerante e xenófoba, não deixa, nas últimas sátiras, de se revelar mais moderada, mercê do desencanto de quem não consegue mudar a sociedade e, qual pícaro, se procura adaptar o melhor possível dentro de um quadro claro e contínuo de inadaptação. Em paralelo, pensemos no Lazarilho de Tormes, que, por umas migalhas, se conforma com o adultério da mulher com um membro da igreja local; ou nos naturalistas e realistas portugueses do séc. XIX que, conscientes da incapacidade de mudarem o mundo, formaram o grupo dos vencidos da vida.

${ }^{39}$ Zeitlin 1971 56-82, esp. 66. 


\title{
Regressar ao Passado na Roma Cristã: história E IDEOLOgia No PANEGÍRICO PELO SEXTO CONSULADO DE HONÓRIO
}

\author{
Rodrigo Furtado \\ Universidade de Lisboa \\ Centro de Estudos Clássicos
}

1. O dia 1 de Janeiro de 404 não foi um dia normal em Roma: ao longo da Via Flamínia acotovelava-se uma multidão que esperava ver o imperador que regressava à Cidade. Muito longe iam os dias em que o príncipe vivia (quase) sempre em Roma. Desde os tempos em que Nepociano, no ano 350, há mais de cinquenta anos, se tinha proclamado imperador na cidade do Tibre, nunca mais nenhum dos príncipes tinha elegido o Lácio para viver. Nepociano não era sequer um bom exemplo: fora morto por um outro autoproclamado imperador antes de completar um mês de governo. Antes dele, ter-se-ia de recuar a Maxêncio, nos tempos da tetrarquia militar de há quase um século, para encontrar um imperador que tivesse vivido no Lácio durante uma boa meia dúzia de anos, neste caso entre 306-312 - não havia por certo ninguém vivo que recordasse tais tempos. Desde que Constantino, o Grande, preferira as sedes do Reno e, depois, a soalheira cidade do Corno de Ouro, nunca mais um imperador se estabelecera no Palatino, com o seu gigantesco palácio vazio de gente. Desde então, em cerca de cem anos, e descontando o infeliz caso de Nepociano, os imperadores tinham voltado à Cidade apenas sete vezes, e sempre em visita; nunca mais para ficarem (Barnes 1975). A última vez fora em Setembro de 394, depois de o grande imperador Teodósio ter vencido o 'usurpador' Eugénio, no último sobressalto militar pagão contra os novos tempos cristãos.

Ora, Honório, assim se chamava o imperador que regressava agora à Urbe, era o filho mais novo daquele Teodósio, um hispânico que lograra a púrpura nas terras do Bósforo, para depois estender o seu poder também pelo Ocidente. Não era a primeira vez que Honório vinha a Roma: tinha acompanhado o pai em 389 (VI Cons. Hon. 54-76, 425. Cf. Cameron 1969 260, n. 25), na primeira visita que este aí fizera, quando do triunfo celebrado depois da vitória sobre Máximo, outro usurpador com ligações à Urbe. No entanto, nessa visita Honório era demasiado pequeno para se recordar de muita coisa: tinha então à volta de cinco anos. Agora, tinham-se passado quase outros quinze; e já há nove que Honório era imperador; nessa qualidade, nunca até então tinha arranjado tempo ou vontade para visitar a Cidade. Não porque vivesse longe - normalmente, sediava em Milão, a escassos seiscentos quilómetros a norte do Tibre. Mas, na época, Roma não tinha qualquer verdadeira importância 
política; já não era apenas o poder que poderia ser tomado em qualquer outro local fora da Urbe - era o poder que era exercido fora de Roma e apesar de Roma.

Ainda assim, a Urbe mantinha muito do prestígio de outrora - por metonímia, continuava ainda a designar todo o Império; era a sua cidade mais populosa, pelo menos na metade ocidental do Mediterrâneo; e aí se mantinha o antigo senado, com as famílias mais ricas de todo o mundo conhecido, que ainda forneciam muitos dos quadros da administração imperial. O senado tinha enorme prestígio, mas fraca relevância política desde que o eixo do Império se deslocara para o Norte de Itália e para o Oriente. E já ninguém passava por Roma; tinha de se desviar para lá ir. Era o que fazia agora Honório para a investidura formal do seu sexto consulado. Nenhum dos outros cinco consulados merecera tal honra - até o consulado podia agora ser assumido noutras cidades; esta visita era claramente uma excepção.

Mas, havia uma boa razão para este regresso a Roma: no ano anterior, tinham sido derrotados Alarico e os seus Godos, que haviam constituído a maior ameaça externa em solo itálico em quinhentos anos, desde os Cimbros e Teutões dos finais do século II a.C. Alarico atravessara os Alpes Julianos em 18 de Novembro de 401: no De bello Getico, canta-se a comoção sentida pela população em Milão e na Itália (Claud., Get. 213-219; Prud. c. Symm. 2. 700; Jer., In Rufinum 3. 21); em Roma, os senadores mandaram reforçar à pressa a já vetusta muralha de Aureliano (CIL 6.1188, 1189, 1190). No domingo, 6 de Abril (e era um grande domingo aquele dia, porque se celebrava a Páscoa), o general Estilicão enfrentou Alarico em Polência, e, seja devido ao valor das legiões, seja porque Alarico (que era um bom cristão ariano) se recusou a combater em dia santo, a verdade é que os Godos recuaram; em Junho do ano seguinte (Barnes 1976 376), em Verona, Estilicão empurrará Alarico de volta para a Ilíria. A Itália parecia a salvo.

O regresso de Honório a Roma inseria-se, pois, num contexto em que era necessário tranquilizar a muito preocupada aristocracia da Urbe e continuar a assegurar a sua lealdade ao jovem imperador. Estilicão antecedera o príncipe em Roma logo a seguir à batalha de Polência; no final de 403, era Honório que aceitava ser de novo cônsul e, para prestigiar a Cidade, dignara-se vir celebrar o seu (!) triunfo sobre Alarico em Roma e aí revestir as insígnias consulares, como era da tradição.

Naquele dia, pois, os Romanos acotovelavam-se para assistir ao cortejo consular (processus consularis) que, durante tantos séculos, tinha sido costume organizar quando da investidura dos novos cônsules, no primeiro dia do ano (VI cons. Hon. vv. 543-544). Por isso, não é de estranhar que ao longo dos últimos cinco quilómetros da Via Flamínia a multidão tivesse ocupado todos os espaços vazios, à beira da estrada, nos terraços ou nas poucas janelas que 
costumavam sulcar as casas romanas (vv. 543-550). Os senadores tinham ido esperar o príncipe: orgulhosos do seu estatuto e fundados nas suas origens, eram multimilionários que incluíam homens da corte do Imperador, que só vinham a Roma de tempos a tempos, e aristocratas que viviam na Urbe a tempo inteiro, sem prejuízo das temporadas de serviço administrativo e militar em alguma província do Império, ou dos tempos de ócio nas vilas da Toscana ou do sul da Itália. Mal sabiam eles que se preparavam para participar no último triunfo que qualquer imperador romano celebraria em Roma.

Contudo, não se assistia apenas ao regresso dos cortejos consulares à Cidade; Honório procurou também comportar-se como um cidadão, à maneira do grande Trajano, ainda o modelo do optimus princeps para a Urbe. Por isso, chegado à Cidade, não permitira que os «pais» do Império caminhassem à sua frente como determinava o orientalizado e distanciador protocolo imperial, mas fora conduzido entre eles, numa proximidade que os Romanos apreciavam (vv. 550-551). Além disso, a populaça da Cidade queria ver o imperador de perto e interagir com ele (em Milão ninguém se lembraria de ideia tão bizarra).

Não há muitas fontes que permitam documentar esta visita de Honório - como, de resto, qualquer uma das vistas de anteriores imperadores, com a excepção da de Constâncio II, cuja deslocação ao Lácio em 357 foi descrita por Amiano Marcelino (Amm. 16.10.1-17). Nem sequer na numismática surge uma qualquer cunhagem com a epígrafe ADV(entus) AVG(usti), por exemplo. Apenas uma moeda de Honório, com o seu irmão Arcádio, imperador no Oriente, e Teodósio II, filho de Arcádio, datada de entre 402 e 408, se refere a VRBS ROMA FELIX, pelo que pode talvez estar relacionada com esta visita ( $L R B C$ 62). De qualquer modo, o relevo político desta viagem (como as dos antecessores de Honório) era por certo curto. Contudo, não o era o ideológico.

A única fonte que nos permite saber alguma coisa sobre esta visita é um panegírico em verso, da autoria do poeta 'oficial' da corte de Milão, o alexandrino Claudiano: refiro-me ao Panegírico pelo sexto consulado de Honório.

2.É um egípcio de língua grega (Claud. c. m. 41.13-14) este poeta da corte de Honório, onde se comunicava inteiramente em latim e onde deviam ser poucos os que compreendiam alguma coisa da língua de Homero.

O Egipto era o maior alfobre de poetas de todo o Mediterrâneo do século IV (Cameron, 1965). Era a região culturalmente mais dinâmica de todo o Império - e não somente Alexandria, mas mesmo as regiões mais a sul, da soalheira Tebaida. Historiadores, teólogos, matemáticos, filósofos nascem ou passam pelo Egipto; e praticamente todos os poetas de língua grega dos séculos IV e $V$ por aí passaram ou aí viveram, como profissionais, procurando agradar a patronos endinheirados e concorrendo nos jogos e festivais que ainda pululavam em qualquer cidade do Mediterrâneo oriental que se prezasse 
(Cameron 1965). Como diz Eunápio, os Egípcios eram loucos por poesia (Vit soph. 10.7.12). E Claudiano era daqui.

De qualquer modo, Claudiano era uma auis rara. De facto, que um Grego soubesse algum latim, e ainda para mais com o grau de mestria que a sua poesia apresenta, seria suficiente para ser considerado um homem excepcional: como diz Dewar, 'a prosódia de Claudiano é mais apuradamente clássica do que a de qualquer poeta latino dos séculos III-IV' (Dewar 1996 liii). Isso é tanto mais estranho quanto, para os Gregos cultos do Mediterrâneo Oriental, o latim era normalmente mais uma das línguas que lhes soava como bar-bar-bar. Até mesmo um imperador culto como o famoso Juliano tinha tido apenas um domínio 'suficiente' de latim (Amm. 16.5.7).

De qualquer modo, é claro que se aprendia algum latim no Oriente: para os muito poucos que queriam participar na vida política, militar ou judiciária do Império (e para quê, se tinham as suas poleis?), o latim tinha alguma importância. O deserto egípcio permitiu que sobrevivessem papiros de Cícero, Salústio, Vergílio ou Juvenal; e que se tenha conservado um delicioso exercício de escola de um aluno egípcio que procurou reescrever num latim correcto parte da célebre descrição do friso do templo de Juno no primeiro canto da Eneida (1.477-493; cf. Moore 1924). Cristodoro, outro poeta egípcio, refere explicitamente a Eneida (Anth. Pal. 2.414) e o célebre Nono parece imitar Ovídio (Cameron 1970 20). Olimpiodoro, um poeta e historiador greco-egípcio, também visita Roma (Matthews 1970). Contudo, nunca deve ter escrito uma linha em latim. E há também o importantíssimo Amiano Marcelino, o maior historiador do século IV, um Grego de Antioquia no Orontes, que vive no Ocidente e escreve a sua História em latim. Mas, apesar destas honrosas excepções, elas são isso mesmo, excepções.

Pouco ou nada se sabe sobre a carreira de Claudiano, antes de 394. Ainda em Alexandria, compôs uma Gigantomachia em Grego (c.m.53). Alan Cameron admite que tenha também cantado Patriai (poemas dedicados à fundação de cidades) em Beirute, Tarso, Anárzabo (na Cilícia) e Niceia (Anth. Pal. 1.19; cf. Cameron 1970 8-11, 26). Perderam-se. Se Claudiano cantou estas Patriai, significa que, ao deixar o Egipto, deve ter rumado por terra à Fenícia e daí à Cilícia, para depois, atravessando a Ásia Menor, se abeirar de Constantinopla. Para um poeta de língua grega à procura de patrono, a cidade do Corno de Ouro devia parecer um mundo de oportunidades. E, de facto, depois dele, pelo menos Ciro (PLRE 2.336-339) e Pamprépio de Panópolis (Asmus 1913) hão-de ganhar fama na cidade do Bósforo, nas cortes de Teodósio II e de Zenão, respectivamente. Contudo, Claudiano, não.

No final de 394, ele já estava em Roma: continuava à procura de um rico patrono. E desta vez conseguiu-o, junto da família cristã dos Anícios, estirpe de cônsules e de prefeitos do pretório, no momento em que dois dos 
seus jovens, Olíbrio (PLRE 1.639-640, 'Anicius Hermogenianus Olybrius 1') e Probino (PLRE 1.734-735, 'Anicius Probinus 1'), conseguiam o apoio imperial para se tornarem cônsules ordinários para o ano 395. Foram eles que encomendaram a Claudiano o seu primeiro trabalho (conhecido) em latim compor um panegírico em verso para a sua investidura consular. E que tarefa! Os dois rapazes nunca tinham feito nada e apenas tinham merecido o favor de Teodósio por serem Anícios e cristãos. Apesar disso, o Panegírico pelo consulado de Olíbrio e Probino revelou-se um êxito.

Em 395, Claudiano estava já em Milão, na corte do pequeno imperador, então de dez anos, Honório (Teodósio morreu em 17 de Janeiro de 395), inserido no círculo do poderosíssimo Estilicão (PLRE 1.853-858, 'Flavius Stilicho'). Este último era filho de um Vândalo; conseguira casar com Serena, a sobrinha preferida de Teodósio, e assim entrar na família imperial. Com a morte de Teodósio, Estilicão tornara-se regente da criança que era imperador.

O panegírico de Olíbrio e Probino deve, de facto, ter causado muito boa impressão, porque, quando o imperador Honório foi designado cônsul (e já pela terceira vez durante a sua curta vida) para o ano 396, coube a Claudiano fazer o seu panegírico; e depois, em 398, pelo quarto consulado do príncipe; e ainda, de novo, pelo casamento entre o imperador e a filha mais velha de Estilicão, Maria, que ocorreu em Fevereiro de 398. Como mostrou Alan Cameron (1970), não era tanto a Honório que Claudiano pretendia (e devia) agradar em qualquer dos seus poemas. Quem mandava era Estilicão e, por isso, não é de estranhar que, já desde o Panegírico pelo Terceiro consulado de Honório, Estilicão surja como a principal personagem a elogiar (cf. O’Flynn 1983).

3. Como é fácil de ver, Claudiano ganhou experiência em panegíricos. Mas, quando, em 404, compôs o Panegírico pelo sexto consulado de Honório, deve ter sido uma espécie de regresso ao passado: é que, tal como o primeiro panegírico que Claudiano compusera em latim, também este seria recitado na Cidade do Tibre. Recordo que, quando chegara a Roma em 394, Claudiano era apenas um poeta promissor. A sua fama acabara por lhe granjear o título de uir clarissimus, permitindo que ele atingisse o lugar mais alto a que poderia ambicionar - pertencer ao senado de Roma. Talvez para celebrar esta promoção, o próprio senado dedicara-lhe uma estátua no mais espectacular dos fora romanos, o enorme forum de Trajano: a inscrição chegou até nós (CIL 6.1710) - Claudiano é apresentado como uir clarissimus, notarius e tribunus.

Compor um panegírico significava, antes de mais, entrar no domínio da convenção e do artifício. O Panegírico pelo Quarto consulado de Honório, também de Claudiano, é mesmo considerado um exemplo perfeito do Basilikos logos, o discurso em honra do governante (Cameron 1965 478, n.5). É claro que o discurso que celebrava um consulado não era bem a mesma coisa do que um texto sobre 
o basileus; contudo, os teóricos da retórica antiga não pareciam fazer a distinção. $\mathrm{Na}$ época de Claudiano, o texto mais conhecido que ensinava como organizar um discurso em honra de alguém era o manual de retórica de Menandro retor (Russell \& Nilson 1981, ed.). E Claudiano segue a grelha com eficácia: no Panegírico pelo sexto consulado encontramos uma 'introdução' (vv. 1-25; prooimion), o elogio da linhagem de Honório (vv. 25-64; gens/genesis), a referência à sua educação (vv. 65-100; natrophê), o desenvolvimento dos seus feitos (vv. 101-648; praxeis) e o epílogo (vv. 649-60; epilogos) ${ }^{1}$. Naturalmente, a parte mais desenvolvida é a dos feitos do Imperador: aqui são tão óbvios os tons épicos que Dewar sugere que pelo menos uma parte destes 'feitos' possa ter originalmente sido elaborada para um poema épico, talvez para o segundo livro do De bello Getico do mesmo Claudiano, que nunca se chegou a compor (Dewar 1996 xxviii).

Este é, pois, o contexto em que decorre a actio, ou seja, a declamação do Panegírico pelo sexto consulado de Honório. E é numa perspectiva histórica que me quero manter. O objectivo inicial deste trabalho era o de comentar a prosopopeia de Roma neste poema (356-493). Não é a única na obra de Claudiano. Roma aparece com as vestes de Minerva logo no Panegírico pelo consulado de Olíbrio e Probino (75-173), como faminta e esquálida no Da guerra contra Gildão (17-122), como anciã veneranda no Contra Eutrópio (vv. 1.371513), ou a dirigir-se em nome das restantes regiões da terra ao próprio regente no Panegírico pelo consulado de Estilicão (2.223-407). A tarefa, no entanto, revelou-se pouco proveitosa. De facto, o comentário à prosopopeia de Roma no Panegírico pelo Sexto consulado foi magistralmente conseguido há já quinze anos por M. Dewar (1996). Pelo contrário, pareceu-me do maior interesse debruçar-me sobre um problema histórico-cultural que releva da presença de Honório em Roma e do contexto ideológico em que Claudiano o insere. Neste ambiente, Poeta, Cidade e Imperador surgem de forma particular.

4.

'Se áureos templos os antigos dedicavam à Fortuna Regressada Quando do retorno dos generais, nunca mais digno foi que merecidamente esta deusa solicitasse amplos santuários do que agora quando, de igual modo, a sua majestade restaurou as trábeas e a Cidade'.

Claudiano, Pelo Sexto consulado de Honório Augusto 1-5a.

São estes os primeiros quatro versos e meio do panegírico dedicado ao sexto consulado do jovem Honório. $\mathrm{O}$ texto começa com uma referência à

\footnotetext{
${ }^{1}$ Ver Dewar 1996 xxvi-xxvii. Este autor considera que o Sexto panegírico tem influências do tipo de discurso sobre o Aduentus do rei numa cidade.
} 
Fortuna Regressada a Roma (supõe-se ter ela estado ausente durante algum tempo). Claudiano começa, pois, o seu poema (recorde-se que se destinava a ser declamado na presença do imperador e do senado, provavelmente em pleno Palatino; Dewar 1996 xliv-xlv) por um tópico que aponta para o passado e que deve constituir chave de leitura de toda a composição. Diz Claudiano que, se outrora os antigos haviam dedicado templos à Fortuna Redux, nunca como agora, com Honório, depois do 'abandono' a que a Cidade tinha sido votada pelos anteriores imperadores e de o perigo ter voltado a estar às portas' com os Godos de Alarico, uma tal celebração do regresso da deusa Fortuna pareceria mais adequada, salvas que estavam a Urbe e as trábeas consulares.

Retornaria, pois, a Fortuna a Roma com o Imperador: no espaço, com o cortejo processional, encenava-se o regresso do imperador à Cidade; no tempo, o retorno à Roma antiga, tal como ela tinha sido outrora. Nesse sentido, o imperador no seu carro (e quase podemos imaginá-1o), rodeado por senadores e a avançar pela Via Flamínia, representava simbolicamente o regresso feliz da Fortuna a terras de Roma, de novo, como outrora, metonímia do Império.

Que o senado tenha sido o primeiro a mandar erigir um altar à Fortuna Redux, em 15 de Dezembro de 19 a.C. (Fast. Amit. ad IV Id. Oct. et ad XVIII Kal. Ian.; Fast. Cum. ad XVIII Kal. Ian. Cf. Platner, Ashby 1929, s.u. Fortuna $\operatorname{Redux}$ ), é sinal de um tópico que acompanha o principado desde a sua fundação. Ao colocar o regresso de Honório sob a égide da Fortuna e ao recordar a dedicação de templos, é possível que Claudiano trace implicitamente o paralelo com o fundador de Principado, atribuindo uma dimensão simultaneamente augustana e senatorial à entrada de Honório em Roma.

De resto, não pode ser por acaso que, em latim, a primeira palavra do poema seja aurea, 'áureos'. A palavra refere-se aos templos de telhados de ouro; mas esconde certamente outro sentido: é como se esta primeira palavra projectasse sobre toda a composição o «ouro» como marca dos tempos que regressavam à Cidade, funcionando como chave de leitura ideológica do panegírico. Como com Augusto, a idade do ouro voltaria a caracterizar os novos tempos, e é sob esse signo que Claudiano procura louvar a actuação de Honório/Estilicão e assegurar a Roma a felicidade sempiterna.

A palavra reditus, 'retorno', aparece apenas duas vezes neste Panegírico. Uma, é esta, logo no início. A segunda ocorrência surge no contexto do regresso de Alarico à Ilíria, saindo da Itália, empurrado pelas legiões romanas (VI cons. Hon. 268). Os dois regressos vão assim em direcções opostas: referem-se a um Romano (o próprio imperador) e a um bárbaro. Contudo, implicam-se: o regresso de Honório a Roma é paralelo à libertação e segurança da Itália, como nos tempos áureos de outrora.

E, porque é de regresso que se fala, Claudiano apresenta sinais efectivos que o comprovariam. Já o referi: Honório procurou comportar-se em Roma 
não como um dominus, mas como um cidadão (cf. VI cons. Hon. 559), exibindo deferência pelos pais e mostrando-se um com eles²: ora se fez transportar entre os senadores ( $V I$ cons. Hon. 551), ora, submetendo-se ao juízo do senado (591: sub iudice senatu; repare-se na introdução significativa da preposição, num contexto em que o ablativo simples seria suficiente), convocou o povo aos rostros e apresentou aos patres as causas e a ordem dos acontecimentos e das suas acções (imperii facta), seguindo os exemplos dos antigos (590: ueterum exempla secutus), ora correspondeu ainda à ovação da plebe no Circo (612-617). E verdade que o discurso de Honório no senado deve ter sido um flop (Cameron 1970 385-386). De facto, não será demasiada imaginação supor que o imperador estivesse perdido de nervos, quando o sentaram em plena Cúria Júlia, ainda de pé sob o peso de mais de quatrocentos anos de um passado de generais, cônsules e príncipes. Contudo, talvez regressar ao passado significasse também regressar aos tempos de um Império que encontrava no forum Romanum e na Cúria o seu centro e o seu sustentáculo humano (na elite que o governava) e ideológico (na superioridade dessa elite); ali, o imperador que balbuciava palavras nervosas seria mais um com eles e não seu senhor.

5. Creio que não foi ainda suficientemente explorada a interpretação histórica desta Fortuna Regressada com que Claudiano inicia o Panegírico pelo sexto consulado de Honório. Efectivamente, julgo haver vários sinais de que, no contexto da monarquia imperial do início do século $\mathrm{V}$, este era um tópico que apontava directamente para a política senatorial de Estilicão/Honório. De facto, dizer que a Fortuna regressava a Roma não poderia significar que o Imperador chegava à Urbe para aí agir como um monarca, à maneira de Milão ou de Constantinopla, contra o senado ou apesar do senado. Pelo contrário, anunciar o regresso da Fortuna só podia significar o reposicionamento do senado romano no seu justo lugar político, após anos de afrontas e humilhações.

De facto, se houve alguma coisa que mudou nos primeiros anos do governo de Estilicão-Honório foi a política que Teodósio tinha mantido com o senado de Roma. O último episódio desta relação tumultuosa traduzira-se no apoio de boa parte dos senadores a Eugénio, que assumira em Lyon a púrpura, em 392, sem esperar pela aquiescência de Teodósio, imperador ainda em Constantinopla. $\mathrm{O}$ assunto resolvera-se a mal, com a batalha do lago Frígido, na qual Eugénio e os senadores foram derrotados. Como já vimos, Teodósio fez questão de celebrar o triunfo em Roma (Williams, Friell 1994 90-121).

Por isso, quando Honório sucedeu ao pai na metade ocidental do Império (o seu irmão mais velho, Arcádio, ficara com o Oriente), não granjeava por

${ }^{2}$ Já Constâncio II, procurara encenar proximidade, quando da sua visita a Roma (Amm. 16.10.13). 
certo a simpatia de muitos dos membros da Cúria. Daí, talvez, a sua pouca vontade em visitar a Cidade; até que, por causa de Constantinopla, a corte milanesa foi obrigada a mudar de estratégia.

O conflito entre as cortes de Milão e de Constantinopla é complexo; radica menos na antipatia entre os imperadores irmãos do que na disputa pelo poder entre os homens que de facto governavam, Estilicão, no Ocidente, e primeiro Rufino e depois Eutrópio, no Oriente. O episódio central foi a declaração de Estilicão como 'inimigo público' no Verão de 397, por parte do senado de Constantinopla (Zos. 5.11.1). Esta declaração tornava nulas as suas acções e deixava o regente de Honório fora-da-lei e sem grande espaço de manobra política e militar.

Ao mesmo tempo, e por certo de forma concertada, logo no Outono de 397, Gildão ( $P L R E$ 1.395-396, 'Gildo'), um príncipe berbere do Norte de África, suspendeu os envios de cereais para a Itália: sem cereais da Proconsular e sem cereais do Egipto (este sob domínio directo de Constantinopla), tardaria pouco para que os efeitos da fome se fizessem sentir em território itálico. E, sem legitimidade legal reconhecida pelo Oriente, Estilicão via-se de mãos atadas, e correndo o risco de ser considerado o culpado pela situação (Cameron 1970 93-123, Long 1996 222-238).

Estilicão jogou então uma boa cartada: procurou o apoio do senado em Roma (antes que fosse este a pedir a sua cabeça; cf. Stil. 1.325-332). Bem a propósito, 'já Estilicão recupera o costume negligenciado durante tantos séculos', pôde Claudiano cantar em 400, numa variação que apontava já para o tópico ideológico do regresso ao passado (Stil. 1.327-329). Esse costume aqui referido era o de fazer depender do senado a declaração formal de uma guerra. De facto, o discurso da declaração de guerra a Gildão coube ao famoso Símaco, um dos mais prestigiados senadores. Restaurada a iniciativa senatorial, Gildão foi derrotado, pondo fim à própria vida em 398.

Neste último ano,Estilicão foi ainda mais longe na recuperação dos poderes da Cúria: devolveu aos senadores o seu antigo direito de julgar magistrados acusados de algum crime (Claud. Stil. 3.99-119; cf. Cameron 1970 234-235). Percebe-se porquê: como 'inimigo público', Estilicão estava muito limitado para perseguir judicialmente os governadores do Norte de África, que tinham sido nomeados entretanto por Constantinopla e/ou que tinham apoiado Gildão, clara ou tacitamente. No entanto, seriam irrepreensivelmente legais os processos instaurados e conduzidos pelo senado de Roma, de acordo com a tradição.

Entretanto, em 399, Eutrópio cai em desgraça no Oriente e é executado (Cameron 1970 143-149). E Estilicão pôde finalmente ser designado cônsul para o ano 400. Assume o cargo em Milão, mas convida os senadores para a investidura (Claud. Stil. 2.408-413). Na presença do senado deslocado 
a Milão, Claudiano há-de declamar os Livros I-II do seu Panegírico pelo consulado de Estilicão (Cameron 1970 232-233). Quando Estilicão visita Roma provavelmente no mesmo ano, Claudiano há-de acompanhá-lo e ali recita o livro III do Panegírico pelo consulado de Estilicão, onde o tópico do regresso ao passado volta a aflorar e onde se encontra o mais importante louvor da Cidade na literatura do século IV (Claud. Stil. 3.130-160). Em plena Roma, Claudiano salienta o papel do senado na guerra contra Gildão e na punição dos culpados, apresentando explicitamente a acção do imperador como sujeita ao arbítrio da Cúria (vv. 113-119); é por certo um exagero, mas aponta para o regresso idealizado ao passado e é sinal das boas relações entre Honório/ Estilicão e a Cúria.

Pouco mais tarde, perante a ameaça de Alarico, em pleno Inverno de 401-402, o senado decide enviar aquele mesmo Símaco até Milão, para pedir o apoio imperial (Symm. epp. 4.9, 5.94, 5.95, 5.96, 7.13, 7.14; cf. Barnes 1976 381-383). Depois, no final de 402, e apesar do seu conhecido paganismo, Honório permitirá que o senador Flávio Rumorido, um reputado militar, assuma o consulado nada menos do que com o pequeno Teodósio, o herdeiro de Arcádio (PLRE 1.786, 'Flavius Rumoridus'). Na mesma altura, antes de 6 de Dezembro de 402, o prefeito da Cidade, um cristão chamado Macróbio Longiniano (PLRE 2.686-687, 'Flavius Macrobius Longinianus'), correspondente de Agostinho de Hipona, foi substituído por Cecina Décio Albino (cf. Cod. Theod. 7.13.15), um senador pagão (PLRE 1.35-36, 'Caecina Decius Albinus Iunior 10'). Estes casos mostram que Honório e Estilicão estavam longe, antes pelo contrário, de hostilizar os pagãos do senado.

Depois, em 404, é o próprio imperador quem regressa a Roma, o principal sinal de uma Fortuna Regressada que recentra politicamente o senado.

6. É particularmente relevante o primeiro sinal efectivo deste regresso do passado, referido por Claudiano no Panegírico pelo sexto consulado de Honório. Logo no início da composição, Claudiano assegura que este sinal teria sido a escolha de Honório para o consulado, nada menos do que em eleições tradicionais nos até então extintos comícios centuriatos, no Campo de Marte (vv. 5-10).

[...] não já o solene campo e a urna fingem

como de costume, nem brilha quem tem uma língua diferente

ou a aparência estrangeira de um direito forjado.

O Palatino natal recebe as vestes romanas

E, enquanto aos castros pátrios Quirino associa a plebe,

Marte recupera os augustos sufrágios do seu campo".

Claudiano, Pelo Sexto consulado de Honório Augusto 1-10. 
De facto, o Campo de Marte tinha sido o local onde, na República antiga, se elegeram os cônsules. E Claudiano é explícito: as eleições do Campo de Marte não teriam agora sido simuladas, fingindo um processo que anteriormente era decidido noutro lado (em Milão) e por outros que não o 'povo romano'; nas eleições não vencera aquele que falava um deficiente latim nem aquele que, parecendo estrangeiro (Claudiano usa a palavra técnica 'peregrino'), simulava ter direito a desempenhar as magistraturas romanas, numa óbvia referência aos homens de extracção germânica que as vinham assumindo; de novo, no Campo de Marte se recuperara os sufrágios augustos. Este último adjectivo remete para o prestígio das eleições consulares e para o facto de nestas últimas, em 403, se ter elegido o próprio Augusto.

Estará Claudiano a usar de liberdade poética, apenas para prestigiar a eleição de Honório? Ou, de facto, procurou-se recuperar, em 403 d.C., o antigo costume das eleições consulares no espaço dos Saepta Iulia, ali mesmo ao lado do Panteão, no coração do Campo de Marte? Em ambos os casos, tratar-se-ia de um sinal do regresso da Fortuna; no segundo caso, estaríamos perante uma concretização desta reivindicação. Tenha esta eleição sido encenada em Roma ou seja ela um mero motivo poético, em ambos os casos era sempre o regresso ao passado que se pretendia garantir (cf. Dewar 1996 66-70).

8. Claudiano refere também outro acontecimento, porventura ainda mais simbólico deste regresso ao passado que implicava a revalorização do senado.

Efectivamente, enquanto Honório falava ao senado, em plena Cúria Júlia, ao olharem para ele os senadores deparavam com uma parede de 21 metros de altura por trás do príncipe. Ora, no Panegírico pelo sexto consulado, Claudiano reage como se ainda aí se encontrasse um dos principais símbolos do senado, a estátua tarentina da grande deusa alada Vitória. Canta Claudiano (VI cons. Hon. 597-602):

Presente nos seus templos estava a alada Vitória, da romana toga protectora: com as suas ricas asas ampara o reverendo sacrário da reunião do senado e dos teus castros ela mesma companheira incansável goza agora os seus votos e para todo o sempre se entrega a ti e tu a ela no tempo.

É particularmente difícil de interpretar este passo. Não que seja muito espinhoso este latim de Claudiano; mas é difícil de perceber a que é que ele se está, de facto, a referir. Naturalmente, Claudiano recupera aqui o tópico da vitória militar; é um tema óbvio, já que se celebrava também a vitória romana sobre Alarico. E nem sequer é necessário que presumamos um ambiente não cristão, já que o 'maravilhoso pagão' corresponde a um tópico mais literário do que 
propriamente religioso: seria perfeitamente possível que, no contexto da poesia latina do século IV, um cristão ouvisse sem grandes sobressaltos referências explícitas às divindades pagãs: Honório e Estilicão, por exemplo, eram cristãos. Contudo, nem Cameron é capaz de dizer que, neste passo concreto, estamos no plano do puro convencionalismo literário (Cameron 1970 386). De facto, a deusa Vitória era nada menos do que a divindade em torno da qual tinha rebentado uma das maiores polémicas entre cristãos e pagãos dos últimos anos.

Desde o principado de Augusto, ou seja, desde a inauguração da Cúria Júlia, tinha existido na parede noroeste interior do edifício um altar dedicado à deusa Vitória: tinha sido erguido ainda em 29 a.C., para celebrar Áccio, e Augusto mandara aí colocar uma já antiga estátua da deusa alada Vitória, trazida de Tarento.

Ora, com a conversão ao cristianismo no século IV, os imperadores cristãos continuavam a gostar de poesia povoada de deuses, mas deixaram de achar adequada a presença do altar na Cúria, e sobretudo os sacrifícios que aí se faziam (normalmente fumigações de uns quantos grãos de incenso, que cada senador deveria queimar antes de tomar o seu lugar). Em 357, Constâncio II mandara retirar o altar (Symm. Rel. 3.5,3.7; cf. Edbrooke, 1976); mais tarde, fora reinstalado, talvez com Juliano, para depois o imperador Graciano, em 382, voltar a ordenar a sua remoção (Symm. Rel. 3). Depois, Eugénio recolocara-o, algures em 392-394 (Ambr. ep. 57.6), para ser logo depois retirado de novo por Teodósio, quando da sua segunda e última visita a Roma. Este vai-e-vem do altar fizera estalar o verniz entre muitos senadores romanos e a corte cristã de Milão. Um dos mais prestigiados e cultos senadores, aquele mesmo Símaco que fora incumbido de declarar guerra a Gildão, tinha procurado interceder junto de Valentiniano II e de Teodósio, para que permitissem a reinstalação do altar (Relatio 3). Debalde, em grande parte graças à tenaz oposição do poderoso bispo Ambrósio de Milão (epp. 17, 18).

Que, no ano 402, dois anos antes do Panegírico pelo sexto consulado de Honório, Prudêncio tenha dedicado todo o Livro II do seu poema Contra Simaco a este tema mostra que ele estava longe de estar enterrado (Cunningham 1966, CCSL 126). E não se pense que o tema da Vitória apenas surge no Panegírico pelo sexto consulado de Honório. Já antes ele tinha merecido uma ainda mais ampla referência da parte de Claudiano: no Livro III do Panegírico pelo consulado de Estilicão (vv. 203-208, 213-219a), também declamado em Roma, no ano 400, tinha cantado Claudiano:

Quão altas as aclamações dos próceres, quão completa A alegria, quando, ao erguer-se para o alto, com as suas asas A própria Vitória abre ao general o sagrado templo.

Ó tu que te alegras com a verde palma e és amiga dos troféus Virgem protectora do império, que sozinha curas 
As feridas e nos ensinas a não sentir o trabalho;

[...]

Fica no Lácio para sempre e aos votos do teu senado,

Ó deusa, atende. Que Estilicão adorne muitas vezes os teus

Portais e te traga sempre de volta aos castros.

A ele, acompanha-o favoravelmente nas guerras, a ele trá-lo com a toga

Para os conselhos. Ele sempre te conduziu em tempos de paz,

te conservou, pia, entre os vencidos e nunca manchou

os teus louros com a violência.

Cameron defende que Claudiano se esteja sempre a referir à estátua, mas não ao altar da Vitória: este autor propõe que essa estátua da Vitória sempre tenha permanecido no interior da Cúria, impondo-se à vista de quem entrava, embora sem sacrifícios desde os tempos de Graciano; o altar andara para cá e para lá, mas a estátua continuaria bem visível (Cameron 1970 239-240). De facto, em lado algum se refere Claudiano a um altar; e concedo que a manutenção da estátua teria menos gravidade do que a do altar: afinal, em 29 de Janeiro de 399, um edicto de Honório procurara garantir a conservação das estátuas antigas, contra a destruição que muitos cristãos consideravam necessária (Cod. Theod.16.10.15). Para Cameron, Claudiano estaria a recuperar um tema caro aos senadores pagãos; não falando da restauração do altar da Vitória, Claudiano procuraria agradar ao seu auditório mais pagão, mostrando respeito e garantindo a presença da deusa alada; ao mesmo tempo, alinhava Estilicão, o seu patrono, ao lado dos senadores e dos seus desejos, sem o comprometer com qualquer decisão (Cameron 1970 237-241).

Ora, creio que Claudiano teria arriscado demasiado a interpretação do seu poema, se este apenas se referisse a convenções que piscavam o olho aos senadores pagãos, mas que não falavam de facto sobre o altar. De resto, o texto era certamente ambíguo até para a própria Cúria: ao falar da Vitória em plena cidade de Roma, é claro que Claudiano podia estar a referir-se apenas à estátua. Contudo, tinha também de fazer lembrar o altar, que é, sem dúvida, a primeira coisa que vem à cabeça; à nossa e, por certo, à dos senadores romanos, para quem esse continuava a ser tema de conversa (veja-se Prudêncio). Convenhamos que, mesmo supondo o carácter convencional dos deuses pagãos, uma coisa seria falar da abstracta deusa Fortuna; outra, bem diferente, da Victoria, que tinha constituído símbolo da derrota humilhante do senado no braço de ferro com a corte milanesa. Os senadores não eram tolos ou indivíduos pouco sofisticados. E a referência explícita, em duas ocasiões (nos panegíricos a Estilicão e pelo sexto consulado de Honório), à Vitória em moldes ambíguos que mostrariam a 'veneração' (a palavra é de Cameron 1970 238) do regente pela deusa não era de molde a agradar à Cúria e arriscava-se a ser entendida como uma provocação. 
É o próprio Claudiano que não quer deixar dúvidas: no Panegírico pelo sexto consulado de Honório, a Cúria é apresentada como 'templo' (templis) da Vitória. No Panegírico pelo consulado de Estilicão referia-se também explicitamente a aedes da deusa Vitória, e nada indica que Claudiano esteja a mencionar o tão antigo templo da Vitória que existia no Palatino, como defende Cameron (1970 238). É verdade que, como adverte Dewar, o carácter sacral da cúria é louvado já por Vergílio e por Horácio, e que, tecnicamente, a cúria tinha sido inaugurada, isto é, o seu local tinha sido constituído como sagrado pela consulta dos augúrios (Dewar 1996 395). Contudo, o carácter sacral da Cúria podia ter sido esquecido por Claudiano, até para evitar más interpretações, e não o foi. Pelo contrário, mais à frente, ainda insiste: a Cúria é um sacrário, um local sagrado que deve ser venerado; e é protegida pela Vitória. Mas, Claudiano vai ainda mais longe.

Em todos os manuscritos do Panegírico pelo sexto consulado de Honório que chegaram até nós (cf. Dewar 1996 40, v. 601), encontra-se a expressão 'fruitur uotis' (VI cons. Hon. 601; lit. 'goza dos votos/desejos'), referindo-se à própria Vitória. Sem qualquer apoio nos manuscritos, mas precisamente porque a expressão é ambígua, Dewar (1996 397) propõe a alternativa 'fruitur iunctis' ('goza da união', scil. dela própria, Vitória, com o imperador). Francamente, não vejo razão para aceitar a emenda; não vejo por que razão os votos de que a Vitória estaria a gozar com o regresso de Honório não poderiam ser os únicos que conhecemos no contexto da 'vida' recente da deusa: os votos pela restauração do seu altar.

A alternativa que proponho é, no fundo, que se recupere a antiga tese de Birt, para quem em 399-400, no contexto do consulado de Estilicão, o altar da Vitória teria sido restaurado em Roma (Birt 1885 lviii n.1). Esta possibilidade explicaria bem, sem quaisquer malabarismos interpretativos, o texto de Claudiano. Francamente, não vejo o que se perde em termos de entendimento histórico da época ao considerar esta restauração como facto. Contextualmente, ela explicar-se-ia muito bem: inserir-se-ia na inversão da política senatorial de Teodósio. Estilicão estava numa posição débil e precisava da legitimação que os 'pais' lhe podiam conferir. Neste contexto, entende-se bem que a reinstalação do altar da Vitória se incluísse no âmbito de um tópico ideológico que reclamava como actual o regresso ao passado - esse regresso ao passado, anunciado por Claudiano desde 400, com o Panegírico a Estilicão, encontraria na restauração do altar augustano da Vitória um dos seus melhores símbolos.

Dir-se-á que nenhuma outra fonte refere este facto, que teria certamente causado alguma reacção. Contudo, o altar da Vitória já tinha sido retirado da Cúria em 357 (Ambr. ep. 18.32, Symm. rel. 3.4, 3.6), e também sabemos que ele foi com toda a certeza restaurado antes de Graciano o voltar a remover 
em 382. Contudo, nenhuma fonte nos diz quando isso ocorreu, embora seja provável que os senadores tenham aproveitado o principado de Juliano. Mesmo a polémica que opôs Símaco a Ambrósio sobre o altar da Vitória apenas nos é conhecida pelos textos destes dois autores e pelo de Prudêncio. Jerónimo, que viveu em Roma entre 383 e 385, não menciona esta polémica na sua abundante correspondência, logo ele que nessa altura gravitava nos círculos senatoriais cristãos. Agostinho de Hipona, que na época devia estar em Milão, também nunca a refere. Ou seja, não creio que a ausência de referências a estoutra restauração do altar seja sinal suficiente para descartá-lo como mero fruto da imaginação poética ou como possível modo de captar a simpatia dos pagãos da Cidade.

De resto, não é bem verdade que não haja qualquer referência a este tema da restauração do altar da Vitória no início do século V. Já referi que Prudêncio escreveu em 402 um longuíssimo poema em 2 livros, Contra Simaco. No segundo livro, ele recupera os argumentos de Símaco a favor do altar da Vitória para os rejeitar. Cameron e, mais recentemente, Michael Brown, consideram que o Contra Simaco procura retomar argumentos contra o senador pagão, mas do ponto de vista puramente formal, sem que a questão do altar tivesse voltado a surgir (cf. também Brown 2003 8-20). É verdade que também Orígenes escreveu o Contra Celso oitenta anos depois da obra deste autor, e que o próprio Prudêncio, nos seus Hamartigenia, atacava Marcião, que vivera trezentos anos antes. Contudo, estes argumentos não me parecem decisivos. Nada impede que, como Timothy Barnes também admite, Prudêncio esteja a responder ao recrudescimento da polémica (Barnes, 1976). Em bom rigor, devemos admitir a nossa ignorância; e não devemos, desnecessariamente, descartar qualquer das hipóteses. O meu ponto é o seguinte: a revisitação da polémica em torno do altar da Vitória por parte de Prudêncio surgiu precisamente ao mesmo tempo, o que é uma extraordinária coincidência, em que aparecia o mesmíssimo tema na poesia de Claudiano. E, creio, essa possibilidade deve ser tida em conta.

Entendo assim que o Panegírico pelo sexto consulado de Honório se insere num ambiente de recuperação das tradições políticas 'urbanas' em Roma do final do século IV-início do século V. A situação militar mostrava dificuldades e as relações com Constantinopla mantinham-se tensas; em Roma, a dinastia de Teodósio nunca fora bem aceite; o imperador era demasiado jovem e sem talento para assumir a direcção política do Império, deixando o poder nas mãos de Estilicão, que se tornara o governante de facto. É num contexto em que a sua posição é questionada a Oriente e em que o solo italiano se encontra ameaçado como nunca nos últimos quinhentos anos, que Estilicão procura o apoio da Cidade: reforça os poderes do senado; recupera talvez, pelo menos em 403, 
o modelo antigo das eleições no Campo de Marte; e, já antes disso, permite possivelmente a restauração do altar da Vitória.

Podemos imaginar que a entrada de Honório em Roma tenha assistido a um imperador amedrontado, habituado a uma etiqueta distanciadora e agora lançado à multidão romana, barulhenta, curiosa, tantas vezes impiedosa, ou a senadores acostumados a um dolce far niente que Alarico se atrevera a pôr em causa. O Panegírico pelo sexto consulado de Honório foi o último trabalho (conhecido) de Claudiano - não deixou outro registo depois de 404. Estilicão vê fracassada a sua política e acabará derrotado e executado em 408. Em 24 de Julho de 410, foi a vez de Alarico, regressado a Itália, entrar na Cidade, para a saquear durante três dias. Os senadores, que apenas seis anos antes haviam acolhido Honório e a Fortuna que ele simbolizava, fugiram para as suas terras do sul da Itália, da Sicília ou do Norte de África; e a Vitória que abrira as suas asas para o pequeno imperador foi deixada para trás. Em Itália, cercado no seu reduto de Ravena, ficou Honório. Ser capaz de encenar um regresso ao passado, teria sido uma boa possibilidade de sobrevivência. Não podia saber o que o esperava. Falhou redondamente. 


\section{Bibliografia Geral}

\section{Edições, traduções, comentários, indices}

C. A. André (2006), Ovídio. Amores. Lisboa, Cotovia.

F. Bömer (1969), P. Ovidius Naso. Metamorphosen, Kommentar von F. Bömer I-III. Heidelberg.

(1976), P. Ovidius Naso. Metamorphosen, Kommentar von F. Bömer, Buch VI-VII. Heidelberg.

P. Brandt (1902), P. Ovidi Nasonis, De arte amatoria libri tres, erkl. Leipzig (repr. Hildesheim 1963).

S. M. Braund (1996), Juvenal. Satires, book I, ed. Cambridge, University Press.

L. M. Cerqueira et alii (2003), Eneida. Lisboa, Bertrand.

M. Citroni (1975), Epigrammaton liber I. Introduzione, testo, apparato critico e commento. Firenze, La Nuova Italia.

K. M. Coleman (1988), Statius. Silvae IV, ed. with an English translation and commentary. Oxford (repr. 1998).

(2006), M. Valerii Martialis Liber Spectaculorum. Edited with introduction, translation and commentary. Oxford, University Press.

E. Courtney (1980), A Commentary on the Satires of Juvenal. London, Athlone. (1990), P. Papini Stati Silvae. Oxford (repr. 2008).

M. P. Cunningham, ed. (1966), Aurelii Prudentii Clementis carmina. Turnholti.

M. J. Dewar, ed. (1996), Claudian. Panegyricus de sexto consulatu Honorii Augusti. Oxford.

G. Galán Vioque (2002), Martial, book VII. A commentary. Translated by J. J. Zoltowsky. Leiden/Boston/Köln, Brill.

G. F. Else (1967), Aristotle's Poetics: the argument. Cambridge (Mass.). Harvard U. P.

P. B. Falcão (2008), Horácio. Odes. Cotovia, Lisboa.

P. Fedeli (1980), Properzio. Elegie. Libro I. Firenze. (1985), Properzio. Il libro terzo delle elegie, a cura di P. Fedeli. Bari.

L. Galasso (1995), P. Ovidii Nasonis. Epistularum ex Ponto Liber II. Firenze.

J. W. Geyssen (1996), Imperial panegyric in Statius. A literary commentary on "Silvae" 1.1. New York/ Bern, Peter Lang. 
K. W. Gransden (1976), Virgil, Aeneid, Book VIII. Cambridge Greek and Latin Classics, C.U.P.

A.S. Hollis (1977), Ovid. Ars Amatoria, Book I, ed. with an intr. and comm. by A.S. Hollis. Oxford.

P. Howell (1980), A Commentary on Book One of the Epigrams of Martial. London, The Athlone Press.

N. M. Kay (1985), Martial book XI: a commentary. London, Duckworth.

P. Labriolle et F. Villeneuve (21971), Juvénal. Satires, ed., trad. et notes. Paris, Les Belles Lettres.

G. Laguna (1992), Estacio Silvas III, introd., edición critica, trad. y comentario. Sevilla, Fundación Pastor de estudios clásicos.

T. J. Leary (1996), Martial Book XIV. The Apophoreta. Text with introduction and commentary. London, Duckworth.

R. J. Littlewood (2006), A commentary on Ovid: "Fasti" Book VI. Oxford, Oxford University Press.

D. W. Lucas (1968), Aristotle. Poetics, intr., comm. and appendixes. Oxford, Clarendon.

R. Maltby (2002), Tibullus: Elegies. Text, Introduction and Commentary. Cambridge, (com apêndice em que se reúne a bibliografia tibuliana 1970-2000).

J.C. McKeown (1989), Ovid, Amores. Text, Prolegomena and Commentary. Volume II. A Commentary on Book One. Leeds.

(1998), Ovid, Amores. Text, Prolegomena and Commentary. Volume III. A Commentary on Book Two. Leeds.

D. Francisco Manuel de Melo (1651), Carta de Guia de casados (com grafia atualizada por Daniel Neto Rocha, em Coimbra, CELGA, 2007). Lisboa, Oficina Craesbeeckiana, 1651.

R. Moreno Soldevila (2006), Martial, Book IV. A commentary. Leiden/Boston, Brill.

A. Nascimento, coord. (2002), Propércio. Elegias. Lisboa/ Assis, Centro de Estudos Clássicos/ Accademia Properziana del Subasio.

R. M. Ogilvie (1970), A Commentary on Livy, books 1-5. Oxford, Oxford University Press 75-76.

J. Perret (1977-1980), Virgile. Énéide. Texte établi et traduit. Paris, Les Belles Lettres, I-III.

M. C. Pimentel et alii (2000, 2001, 2004), Marcial, Epigramas, vol. I-IV, introdução, tradução e notas. Lisboa, Edições 70. 
R. G. M. Nisbet e M. Hubbard (1970), A Commentary on Horace: Odes, Book 1. Oxford, Clarendon Press.

E. Pianezzola (1991), Ovidio. L'arte di amare, a cura di E. Pianezzola. Commento di G. Baldo, L. Cristante, E. Pianezzola. Milano.

R. Pichon (1902), Index verborum amatoriorum. Paris.

M. C. J. Putnam (1973), Tibullus: a commentary. Oklahoma.

Eça de Queirós (s.d.), A correspondência de Fradique Mendes. Lisboa, Livros do Brasil.

M. H. Rocha Pereira (102007), Platão. A República. Intr., trad. e notas. Lisboa, Calouste Gulbenkian.

N. Rudd (1989), Horace. Epistles, Book II, and Epistle to the Pisones ('Ars Poetica'), ed. Cambridge, University Press.

L. A. Seneca (1998), Iframmenti. A cura di Dionigi Vottero. Bologna, Patròn.

D. R. Shackleton Bailey (1990), M. Valerii Martialis Epigrammata. Teubner, Stuttgart.

F. Socas (1996), Juvenal. Sátiras. Madrid, Alianza Editorial.

L. Watson \& P. Watson (2003), Martial. Select epigrams. Cambridge, University Press.

As Elegias e os Carmes de Tibullo e algumas Elegias de Propercio e Carmes fugitivos de Catullo traduzidos em Portuguez por um curioso obscuro. Porto, 1912, $2^{\mathrm{a}} \mathrm{ed}$.

\section{Estudos}

AAVV (1985), Simposio Tibuliano. Conmemoración del bimilenario de la muerte de Tibulo. Múrcia.

- (1986), Atti del convegno internazionale di studi su Albio Tibulo. Roma.

T. Adamik (1975), "Martial and the vita beatior", AUB 3 55-64.

V. M. de Aguiar e Silva ( ${ }^{81994), ~ T e o r i a ~ d a ~ l i t e r a t u r a . ~ C o i m b r a, ~ A l m e d i n a . ~}$

F. Ahl (1984a), "The art of safe criticism in Greece and Rome", AJPh 105 174-208

(1984b), "The rider and the horse: Politics and Power in Roman Poetry from Horace to Statius", ANRW 2.32.1 40-110.

J. C. Anderson (1984), The historical topography of the imperial Fora. Bruxelles, Latomus. 
W. S. Anderson (1982), Essays on Roman Satire. Princeton, Univ. Press.

C. A. André (1992), "Morte e vida na Eneida", A Eneida em contraluz. Coimbra, Instituto de Estudos Clássicos, 23-75.

(2006a), Caminhos do amor em Roma: sexo, amor e paixão na poesia do séc. I a. C. Lisboa, Livros Cotovia.

(2006b), "Entre o despeito e o respeito: a mulher em Ovídio", Humanitas 58 99-117.

(2010), "A ironia ovidiana na subversão do protocolo amoroso em Roma”, Revista Crítica de Ciências Sociais 89 41-54.

J. L. Andronica (1969), A comparative study of Ovid's treatment of erotic themes in the different genres of his poetry. Baltimore.

R. Armstrong (2005), Ovid and his love poetry. London.

R. Asmus (1913), "Pamprepios, ein byzantinischer Gelehrter und Staatsmann des 5. Jahrhunderts", Byzantinische Zeitschrift 22 337-347.

G. Augello (1968-69), "Roma e la vita romana testimoniata da Marziale", ALGP 5-6 259-260, e n.156.

M. T. S. de Azevedo (1998), "Retórica filosófica feminina em Platão: Aspásia e Diotima" in Juan Miguel Labiano Ilundain et al., eds. Retórica, política e ideología. Desde la Antigüedad hasta nuestros días, vol. I, retórica clásica y Edad Media. Actas del II Congreso Internacional (Salamanca, 1997). Salamanca, Logo, 223-228.

V. Baines (2003), “Umbricius' Bellum Ciuile: Juvenal, Satire 3”, G\&R 502 220-37.

R. J. Ball (1971), The structure of Tibullus's elegies. Diss. Columbia.

D. M. S. Baptista (2009). O Burlesco e o Satírico na obra de Marcial e Juvenal. Diss. Aveiro, Universidade.

T. D. Barnes (1975), “Constans and Gratian in Rome”, HSCPh 79 325-333. (1976), "The Historical Setting of Prudentius' Contra Symmachum”, AJPh 97 373-86.

U. Bernhardt (1986), Die Funktion der Kataloge in Ovids Exilpoesie. Hildesheim-Zürich-New York.

T. Birt (1885), De fide christiana quantum Stilichonis aetate in aula imperatoria occidentali ualuerit. Marburg.

A. D. Botha (1992), “Aspects of prophecy in Virgil's Aeneid", Akroterion 37, 6-14.

A. J. Boyle (1986), The chaonian dove. Studies in the Eclogues, Georgics, and Aeneid of Virgil. Leiden, Brill. 
P. L. Bowditch (2001), Horace and the gift economy of patronage. Berkeley, University of California Press.

J. L. Brandão (1997), "Marcial e o público e os críticos: autodefesa do poeta", Humanitas 49 177-195. [ = M. C. Pimentel, D. F. Leão e J. L. Brandão (coord.) (2004)]

- (1998), "Marcial e o amor da Liberdade", Humanitas 50 171-172.

(1998), Da quod Amem. Amor e amargor na poesia de Marcial. Coimbra, Colibri / Faculdade de Letras.

(2004), “Amor e morte em Marcial”, Humanitas 56 33-48.

E. Bréguet (1969), "Urbi et orbi, un cliché et un thème”, in J. Bibauw ed. Hommages à M. Renard, I. Bruxelles 1969,140-152.

M. Brown (2003), Prudentius' Contra Symmachum. Book I I. Introduction, translation and commentary, thesis. New Castle upon Tyre.

A. Buchholz (1954), Zur Darstellung der Pathos der Liebe in der hellenistischen Dichtung, Diss. Freiburg i.Br.

G. Burzacchini (1977), "Filenide in Marziale”, Sileno 3 239-243.

L. Cahoon (1998), "The bed as battlefield: erotic conquest and military metaphor in Ovid's Amores", Transactions of the American Philological Association 118 293-307.

F. Cairns (1979), Tibullus: a Hellenistic poet at Rome. Cambridge.

A. Cameron (1965), "Wandering Poets: A Literary Movement in Byzantine Egypt”, Historia 14 470-509.

(1969), "Theodosius the Great and the regency of Stilico", HSChP 73 247-280.

(1970), Claudian: Poetry and Propaganda at the Court of Honorius. Oxford.

W. A. Camps (1969), An introduction to Virgil's Aeneid. Oxford, OUP.

L. Canfora (2003), Um ofício perigoso. A vida quotidiana dos filósofos gregos (trad. port. de Manuel Ruas). Lisboa, Teorema.

F. Castagnoli (1950), "Roma nei versi di Marziale", Athenaeum 28 67-78.

M. Citroni (1988), "Pubblicazione e dediche dei libri in Marziale", Maia 40 3-39.

M. L. Clark (1974), “Aeneid 1. 286-296”, CR 24, 7-8.

K. M. Coleman (1999), "Mythological figures as spokespersons in Statius' Silvae", in F. de Angelis - S. Muth (edd.), Im Spiegel des Mythos. Bilderwelt und Lebenswelt/Lo specchio del mito. Immaginario e realtà. 
Wiesbaden, Dr. Ludwig Reichert Verlag 67-80.

(2003), “Apollo's speech before the battle of Actium: Propertius 4.6.37-54”, in A. F. Basson - W. J. Dominik (edd.), Literature, Art, History: Studies on Classical Antiquity and Tradition in Honour of W. J. Henderson. Frankfurt, Peter Lang 37-45

S. Commager $\left(1995^{2}\right)$, The odes of Horace: a critical study. Nornam and London, University of Oklahoma Press.

G. B. Conte (1997), The Hidden Author: An Interpretation of Petronius's Satyricon. California, University of California Press.

(1986), The Rhetoric of Imitation: Genre and Poetic Memory in Virgil and Other Latin Poets. Ithaca, Cornell University Press.

R. Darwall-Smith (1996), Emperors and architecture. A study of Flavian Rome. Bruxelles, Latomus.

L. Deschamps (1981), "L'influence de la diatribe dans l'oeuvre de Martial", Atti del Congresso Internazionale di Studi Vespasianei. Rieti, Centro di Studi Varroniani, 353-368.

M. Desmond (1993) "When Dido Reads Vergil: Gender and Intertextuality in Ovid's Heroides 7", Helios 20, 56-68.

M. Dewar (2008), “The equine cuckoo: Statius' Ecus Maximus Domitiani Imperatoris and the Flavian Forum", in J. Smolenaars et alii (edd.), The Poetry of Statius. Leiden/ Boston 65-83.

M. A. Di Cesare (1974), The altar and the city. New York - London, Columbia University Press.

C. Dilthey (1863), De Callimachi Cydippa. Lipsiae.

R. Dimundo (2000), L'elegia allo specchio. Studi sul I libro degli 'Amores' di Ovidio. Bari.

R. Dobbin (1995), "Julius Caesar in Jupiter's prophecy, Aeneid, Book 1", ClAnt 14, 5-39.

M. Dolç (1953), Hispania y Marcial. Contribución al conocimiento de la España antigua. Barcelona, Escuela de Filología.

(1957), "La investigación sobre la toponimia hispana de Marcial", EClás 4 68-79.

(1974), "Due passioni di Marziale: Roma e Hispania”, Colloquio italo-spagnolo sul tema: Hispania romana (Roma, 15-16 de maggio 1972), RAL 200 109-125.

(1989), "Marcial, entre Roma y Bílbilis", Actas del simposio sobre Marco Valerio Marcial, poeta de Bilbilis y de Roma (Calatayud, mayo 1986), II. 


\section{Zaragoza, UNED, 11-22.}

R.O. Edbrooke (1976), "The visit of Constantius II to Rome in 357 and its effect on the pagan Roman senatorial aristocracy", AJPh 97 40-61.

A. Espírito Santo (2004), “Toto notus in orbe Martialis. A recepção de Marcial na Idade Média”, Humanitas 56 209-224. [ = M. C. Pimentel, D. F. Leão e J. L. Brandão (coord.) (2004)]

P. B. Falcão (2006), Da noite de Tarento à Luz de um Cântico: o "Carmen Saeculare" de Horácio, música de um ritual. Diss. Lisboa, Faculdade de Letras.

- (2010), "O ofício sagrado do poeta: a música de Horácio nos Jogos de Augusto" in M. C. Pimentel e N. S. Rodrigues (eds), Sociedade e Poder no tempo de Ovídio. Coimbra, Centro de Estudos Clássicos e Humanísticos da Universidade de Coimbra 187-205.

- (2011), O Clímax nas Odes de Horácio: uma análise dinâmica. Diss. Lisboa, Faculdade de Letras.

P. Fedeli (2004), "Marziale Catulliano", Humanitas 56 161-169. [ = M. C. Pimentel, D. F. Leão e J. L. Brandão (coord.) (2004)]

(2010), "Properzio: lo spazio dell'amore", in R. Cristofoli, C. Santini, F. Santucci, (eds). Tempo e spazio nella poesia di Properzio. Assisi 4-26.

P. S. Ferreira (2004), "Marcial e o teatro", Humanitas 56 87-116. [ = M. C. Pimentel, D. F. Leão e J. L. Brandão (coord.) (2004)]

- (2011), "O extispicium no Oedipus de Séneca e a Guernica de Picasso", Revista Mundo E Letras 2 75-84.

W. Fitzgerald (2007), Martial. The world of the epigram. Chicago and London, Univ. of Chicago Press.

C. Flores (2010), "Escrita feminina em Portugal", Interdisciplinas 10 19-27.

J. M. O'Flynn (1983), Generalissimos of the Western Roman Empire. Edmonton, Canada.

E. Fraenkel (1957), Horace. Oxford, Clarendon Press.

P. Frassinetti, (1973), "Marziale poeta serio", in Argentea aetas. In memoriam Entii V. Marmorale. Genova, Istituto di Filologia Classica e Medievale,161-180.

K. Galinsky (1988), “The anger of Aeneas”, AJPh 109, 321-348.

(1996), Augustan Culture: An Interpretative Introduction. Princeton, University Press.

J. M. García González y A. Pociña Perez (eds) (2003), En Grecia y Roma: las gentes y sus cosas. Granada, U. de Granada. 
M. Garrido-Hory (1981), "La vision du dépendant chez Martial à travers les relations sexuelles", Index 10 300-306.

R. Gazich (1995), 'Exemplum' ed esemplarità in Properzio. Milano.

G. Giangrande (1991), "Topoi ellenistici nell'Ars amatoria", in I. Gallo e L. Nicastri (ed.) Cultura, poesia, ideologia nell'opera di Ovidio. Napoli, 61-98.

J. Gil (2004), "Marcial en España”, Humanitas 56 225-326. [ = M. C. Pimentel, D. F. Leão e J. L. Brandão (coord.) (2004)]

T. R. Glover (reimp. 1969), Virgil. New-York, Barnes \& Noble.

A.S.F. Gow (1932), "Diminutives in Augustan Poetry”, CQ 26 150-157.

I. Graça (2004), "Marcial e os banhos em Roma”, Humanitas 56 117-136. [ = M. C. Pimentel, D. F. Leão e J. L. Brandão (coord.) (2004)] (2011). Roma na poesia de Marcial: imagens e ecos de um espaço físico e social. Diss. Universidade de Aveiro.

E. Greene (1994), "Sexual politics in Ovid's Amores 3.4, 3.8 and 3.12", CPh $89.4344-350$.

J. Griffin (1976), “Augustan poetry and the life of luxury”, JRS 66 87-105.

P. Grimal (1983), "Delia meretrix an uxor? "VL 90, pp.3-7. - (1995), L'amour à Rome. Paris, Éditions Payot \& Rivages.

A. Hanson (2010), "Roman Medicine”, in Potter, D. S. (ed.), A Companion to the Roman Empire. Oxford, Blackwell, 492-523.

A. Hardie (1983), Statius and the Silvae. Poets, patrons and epideixis in the Graeco-Roman world. Liverpool, Francis Cairns.

W. V. Harris (2011), Rome's Imperial economy. Oxford, Un. Press.

S. Hinds (2007), "Martial's Ovid / Ovid's Martial”, JRS 97 113-154.

R. Hingley (2005), Globalizing Roman Culture. University, diversity and empire, Routledge.

N. Horsfall (1974), “Virgil Roman chronography. A reconsideration”, CQ 24, 111-115.

ed. (1995), A Companion to the Study of Virgil. Leiden, Brill.

P. Howell (2009) Martial. London, Bristol Classic Press.

J. W. Iddeng (2000), "Juvenal, Satire and the Persona Theory: some Critical Remarks", SO 75 107-129.

T. S. Johnson (2004), A symposion of praise: Horace returns to lyric in Odes $I V$. Madison, University of Wisconsin Press. 
G. A. Kennedy (1989), The Cambridge history of literary criticism. Vol. I, Classical criticism. Cambridge, University Press.

A. Kerkhecker (1999), Callimachus' Book of Iambi. Oxford, Oxford University Press.

H. A. Khan (1966), “Ovidius furens: a revaluation of Amores 1.7”, Latomus 25 880-894.

V. G. Kiernan (1999), Horace: poetics and politics. New York, St. Martin's Press.

K. Kuiper (1984), "The nature of satire”, Poetics 13 459-73.

Í. Lana (1955), "Marziale poeta della contraddizione”, RFIC 33 225-249.

M. Labate (1979), "Poetica ovidiana dell'elegia: la retorica della città", $M D$ 3 9-67.

(1984), L'arte di farsi amare. Modelli culturali e progetto didascalico nell'elegia ovidiana. Pisa.

(1987) "Poesia cortigiana, poesia civile, scrittura epica (a proposito di Verg. Aen. 1.257 ss. e Theocr. 24,73 ss.)”, MD 18, 69-81.

A. La Penna (1977), L'integrazione difficile. Un profilo di Properzio. Torino.

H. Lausberg (1969), Elementi di retorica, trad. it. a cura di L. Ritter Santini. Bologna.

E.W. Leach (1964), "Georgic Imagery in the Ars Amatoria", TrAPhA 95 142-154.

D. F. Leão (2004), "Zoilo e Trimalquião: duas variações sobre o tema do novo-rico", Humanitas 56 191-208. [ = M. C. Pimentel, D. F. Leão e J. L. Brandão (coord.) (2004)]

S. Lilja (1965), The Roman elegist's attitude to women. Helsinki, Suomalainen Tiedeakatemia.

A. M. S. Lóio (2012), Ego Liber: Livros que falam no epigrama latino. Diss. Lisboa, Faculdade de Letras.

K. Lomas ( $\left.{ }^{3} 2003\right)$, "Neapolis", in S. Hornblower - A. Spawforth (edd.), The Oxford Classical Dictionary. Oxford, Oxford University Press 1031-1032.

G. Mader (1988), “Fluctibus Variis Agor: an Aspect of Seneca's Clytemnestra Portrait”, AClass 31 51-70.

M. Malaise (1972), Les conditions de pénétration et de diffusion des cultes égyptiens en Italie. Leiden, Brill.

R. Marache (1961a), "La revendication sociale chez Martial et Juvénal", RCCM 3 38-53. 
(1961b) "La poésie romaine et le problème social à la fin du Ier siècle: Martial et Juvénal”, IL 13 12-13.

J. F. Matthews (1970), "Olympiodorus of Thebes and the history of the West (A.D. 407-425)”, JRS 60 79-97.

C. McNelis (2002), "Greek Grammarians and Roman Society during the Early Empire: Statius' Father and his Contemporaries”, Classical Antiquity 21 67-94.

W. Medeiros (1988), “O poeta que buscava um amor”, Biblos 64 1-15. (1992), “A outra face de Eneias", $A$ Eneida em contraluz. Coimbra, Instituto de Estudos Clássicos, 7-22. (2004), “A cinza falante do poeta", Humanitas 56 5-11. [ = M. C. Pimentel, D. F. Leão e J. L. Brandão (coord.) (2004)]

S. Merkle (1983), "Amores 3,2 und Ars Amatoria 1,135-162 - Ein Selbstplagiat Ovids?”, ZAnt 33 135-145.

J.F. Miller (1996-97), "Meter, Matter and Manner in Ovid, Ars Amatoria 1,89-100”, ClW 90 333-339.

P. A. Miller (1989), "Siue deae seu sint dirae obscenaeque uolucres", Arethusa 22, 47-77.

P. Millett (1989), "Patronage and its avoidance in classical Athens", in Andrew Wallace-Hadrill, ed. Patronage in ancient Society. London and New York, Routledge, 15-47.

S. L. Mohler (1967), "The cliens in the time of Martial”, in Classical Studies in honor of John C. Rolf. New York, Books for Libraries Press, Inc. 239-263.

M. Molina Sánchez (2003), "El maestro en Roma” in J. M. García González y A. Pociña Perez (eds), En Grecia y Roma: las gentes y sus cosas. Granada, U. de Granada, 213-234.

C. H. Moore (1924), "Latin exercises from a Greek Schoolroom”, Class. Phil. 19 317-326.

H. Mouritsen (2011), The freedman in the Roman World. Cambridge, University Press.

M. N. Muñoz Martín (2003), "El poeta en Roma” in J. M. García González y A. Pociña Perez (eds), En Grecia y Roma: las gentes y sus cosas. Granada, U. de Granada, 235-252.

P. Murgatroyd (1982), Ovid with love. Selections from Ars amatoria I and II. Chicago.

P. Murray, ed. (1996), Plato on Poetry. Ion, Republic 376e-398b, Republic 
595-608b. Cambridge, University Press.

R. R. Nauta (2002), Poetry for patrons. Literary communication in the age of Domitian. Leiden, Brill.

Kerill O'Neill (1999), “Ovid and Propertius: reflexive annotation in Amores 1.8”, Mnemosyne 52.3 286-307.

J.P. Néraudau (1985), "Rome dans l'Art d'aimer", in J.M. Frécaut - D. Porte ed. Journées ovidiennes de Parménie, "Actes du Colloque sur Ovide", 24-26 giugno 1983. Bruxelles 25-39.

C. Neumeister (1986), Tibull: Einfurung in sein Werk. Heidelberg.

C. Newlands (2002), Statius' Silvae and the poetics of Empire. Cambridge, Cambridge University Press

R. G. M. Nisbet (2007), "Horace: life and chronology" in S. J. Harrison (ed.), The Cambridge companion to Horace. Cambridge, Cambridge University Press 7-21.

D. Obbink (2004), "Posidippus on papyri then and now", in B. Acosta-Hughes - E. Kosmetatou - M. Baumbach (edd.), Labored in Papyrus Leaves. Cambridge (Mass.)/ London, Harvard University Press 16-28.

E. Oliensis (1998), Horace and the rhetoric of authority. Cambridge, Cambridge University Press.

A. Otto (1890), Die Sprichwörter und sprichwörtlichen Redensarten der Römer. Leipzig.

J.-M. Pailler (1981), “Martial et l'espace urbain”, Pallas 28 79-87.

D. Palombi (1996), "Roma" in S. Mariotti (ed.), Orazio: Enciclopedia Oraziana. Roma, Istituto della Enciclopedia Italiana, vol. 1, 533-553.

U. E. Paoli, (1956), "Il poeta di Roma vivente", Avventure e segreti del mondo greco e romano. Firenze, Le Monnier, 552-567.

V. S. Pereira (1992), "Sementes de frustração na Eneida", A Eneida em contraluz. Coimbra, Instituto de Estudos Clássicos, 77-132.

M. C. Pimentel (1990), "Eneias ou o homem em busca de si mesmo", Classica 2, 123-182.

(1992), "Marcial anacronizado: um cronista de hoje na Roma de ontem", Euphrosyne NS.20 165-186.

(1993), A adulatio em Marcial. Diss. Lisboa, Faculdade de Letras.

(1993), "Quid petitur? Do sonho e do desencanto em Marcial", Euphrosyne NS.21 249-261.

(2000), "Quid non longa dies, quid non consumitis anni? O tempo dos 
homens e o tempo das cidades nos Epigramas de Marcial, Euphrosyne NS 28 221-230.

, D. F. Leão e J. L. Brandão (coord.) (2004), Toto notus in orbe Martialis. Celebração de Marcial 1900 anos após a sua morte. Coimbra, IEC - CECH / Lisboa, DEC-CEC (=Humanitas 56 5-326).

(2004), "Política e história nos Epigramas de Marcial", Humanitas 56 13-31. [ = M. C. Pimentel, D. F. Leão e J. L. Brandão (coord.) (2004)]

S. B. Platner - Th. Ashby (1929), A topographical dictionary of ancient Rome, 3 vol. London.

J. Powell (1987), "The farrago of Juvenal 1.86 reconsidered", in Michael Whitby, Philip Hardie and Mary Whitby, eds. Homo uiator. Classical essays for John Bramble. Bristol - Illinois, Bristol Classical Press Bolchazy-Carducci, 253-8.

R. E. Prior (1996), "Going around Hungry: Topography and Poetics in Martial 2.14", AJPh 121-141.

- (1987), "Virgil's Inferno", MD 18, 165-202.

(1998), Virgil's epic designs. Ekphrasis in the Aeneid. New Haven London, YUP.

(2000), Horace's Carmen saeculare: ritual magic and the poet's art. New Haven, Yale University Press.

K. Quinn (1968), Virgil's Aeneid. A critical description. London, Routledge \& Kegan Paul.

R.S. Radford (1923), "Tibullus and Ovid (Part II). Study of language", AJPh 44 230-259.

J. C. Relihan (1993). Ancient Menippean Satire. Baltimore and London.

V. Rimell (2008), Martial's Rome. Empire and the ideology of Epigram. Cambridge, University Press.

J.-N. Robert (1997), Eros Romain: sexe et morale dans l'ancienne Rome. Paris, Les Belles Lettres.

_-_(2004a), "Société et cultus a l'époque de Martial", Humanitas 56 48-68. [ = M. C. Pimentel, D. F. Leão e J. L. Brandão (coord.) (2004)] - (2004b), "Virtus romana et taedium uitae. Remarques sur l'évolution des mentalités et de la morale à l'époque de Martial", Humanitas 56 69-86. [ = M. C. Pimentel, D. F. Leão e J. L. Brandão (coord.) (2004)]

M. H. Rocha Pereira ("2009), Estudos de História da Cultura Clássica, II vol. Cultura Romana. Lisboa, Fundação Calouste Gulbenkian.

N. S. Rodrigues (2005), Mitos e Lendas. Roma Antiga. Lisboa, Livros e Livros. 
L. Roman (2010), "Martial and the city of Rome", JRS 100 88-117.

D. A. Russell - N. G. Wilson, eds. (1981), Menander rhetor. Oxford.

R. Saller (1989), "Patronage and friendship in early Imperial Rome: drawing the distinction", in Andrew Wallace-Hadrill, ed. Patronage in ancient Society. London and New York, Routledge, 49-62.

F. Savater (2007), Criaturas do ar (trad. de Miguel Serras Pereira a partir de Criaturas del aire, 1979, 2004). Porto, Ambar.

Ch. Segal (1994). Singers, Heroes and Gods in the Odyssey. Ithaca and London, Cornell University Press.

M. F. Silva (1991), "A mulher, um velho motivo de cómico", in Francisco de Oliveira e Maria de Fátima Silva, O teatro de Aristófanes. Coimbra, FLUC, 207-244.

J.B. Solodow (1977), "Ovid's Ars Amatoria: the lover as cultural ideal" WS 11 106-127.

W. Steidle (1962), "Das Motiv der Lebenswahl bei Tibull und Properz", WS 75 100-140.

B. E. Stirrup (1973), "Irony on Ovid's Amores 1.7”, Latomus 32.4 824-831.

J. P. Sullivan, (1991), Martial: the unexpected classic. A literary and historical study. Cambridge, University Press.

C. Teixeira (2007a), Estrutura da viagem na épica de Virgílio e no romance latino. Lisboa, Fundação para a Ciência e Tecnologia - Fundação Calouste Gulbenkian.

(2007b), "Helena na Eneida de Virgílio: as contradições de um mito (En. 2.601-602 e En. 6. 511-530), in José Vicente Bañuls, Maria do Céu Fialho, Aurora López, Francesco de Martino, Carmen Morenilla, Andrés Pociña Pérez, Maria de Fátima Silva (coords.), O mito de Helena de Tróia à actualidade, vol. I, Universitá di Foggia - Universidad de Granada - Universitat de València - Universidade de Coimbra, 273281.

(2008), "O modelo aristotélico na configuração do episódio de Dido na Eneida de Virgílio", AISTHE 2, 3-18.

(2010), "Dido em Ovídio e Virgílio: reflexos do poder no feminino", in Maria Cristina Sousa Pimentel e Nuno Simões Rodrigues (coords.) Sociedade e Poder no tempo de Ovídio. Coimbra, Classica Digitalia, 101-109.

E. Thomas (1969), "Ovid at Races. Amores, III, 2; Ars amatoria, I, 135-164”, in J. Bibauw ed. Hommages à M. Renard, Bruxelles, 710-724.

J. Torrão (2000), "Marcial entre o público e os críticos ou a difícil escolha entre 
agradar aos convivas ou aos cozinheiros" in De Augusto a Adriano. Actas de Colóquio de Literatura Latina. Lisboa, Euphrosyne-CEC, 455-462. - (2004), “Autores de referência na obra de Marcial”, Humanitas 56 137-159. [ = M. C. Pimentel, D. F. Leão e J. L. Brandão (coord.) (2004)]

J. Torrão e A. Andrade (2008), "Os labirintos da cidade: Marcial em Roma”, Ágora 10 63-79.

J. Torrão e J. Costa (2010), "Inveja e emulação em... Marcial: a vida e seus costumes temperados com sal romano" in Belmiro Fernandes Pereira e Jorge Deserto (Orgs.), Symbolon II. Inveja e emulação. Porto, FLUP, 71-101.

D. Van Berchem (1948), "Cynthia ou la carrière contrariée. Essai sur la condition sociale des poètes latins", MH 5 137-154.

J. Veremans (1981), "L'anaphore dans l'oeuvre de Tibule", AC 50, p.774-800.

P. Veyne (1983). L'élégie érotique romaine: l'amour, la poésie et l'Occident. Paris, Éditions du Seuil.

(1988), L'élegie érotique romaine. L'amour, la poésie et l'Occident. Paris.

G.Viansino (1969), "La tecnica didascalica nell'Ars amatoria di Ovidio", Riv. St.Salern. 2 487-502.

L. C. Watson (1983), “Three women in Martial”, CQ 33 258-264.

P. Watson, P (1982), "Martial's fascination with lusci”, GER 19 71-76. (1982), "Erotion: puella delicata?", CQ 42 253-268.

G. Williams (1983), Technique and ideas in the Aeneid. New Haven - London, YUP.

(1995), "Libertino patre natus: true or false?" in S. J. Harrison (Ed.), Homage to Horace: a bimillenary celebration. New York, Oxford University Press 296-313.

R. D. Williams (1990), "The sixth book of the Aeneid", Oxford readings in Vergil's Aeneid, S. J. Harrison ed. Oxford, OUP, 191-207.

S. Williams - G. Friell (1994), Theodosius at bay. London.

J. R. Wilson (1969), “Action and emotion in Aeneas”, GङRR 16, 67-75.

P. Wiseman (1996), "Domitian and the Dynamics of Terror in Classical Rome", History Today 46 19-24

P. Zanker (1989), Augusto e il potere delle immagini. Torino. (2008), Arte romana. Bari-Roma. 
Bibliografia Geral

F. I. Zeitlin (1971), "Romanus Petronius: a study of the Troiae halosis and the Bellum ciuile", Latomus 30, 56-82. 


\section{ÍNDICE TEMÁTICO}

A libellis 128; 144

A rationibus 127

Ab epistolis 144

Áccio, batalha de 31; 32; 40; 43; 57; 63; $166 ; 210$

Adriano, imperador 124; 144; 145; $150 ; 178 ; 182 ; 185$

Adulação 121; 123; 124; 125; 127; 128; $136 ; 152 ; 194$

Ager romanus 136

Agripa 31; 37; 39; 155; 182 n.19

Alexandria 31; 166; 167; 201; 202

Aliteração 59

Altar da Fortuna Redux 205

Altar da Vitória 210-214

Amator 84; 95; 98; 99; 103. Diues a. 52; 59. Exclusus a. 54

Amiano Marcelino 201; 202

Amicitia 34; 44; 50 n.5

Amicus/amici 46; 68; 109; 122; 122 n.3; 128

Anáfora 59; 69; 102 n.59

Anco Márcio 25

Anfiteatro 11; 133; 156

Anfiteatro de Estatílio Tauro 100

Anfiteatro dos Flávios/Coliseu 123; $136 ; 153$

Anquises 12 n.4; 19; 21; 24-27; 25 n.
34 e $35 ; 26$ n. $38 ; 32 ; 33-34 ; 35$ n.

60

Antístio Rústico 127; 128 n.15

Antoninos 8; 121

Arcádia 56

Arcádio 201; 206; 208

Argileto 30; 156; 172

Arrúncio Estela 127; 128 n.15; 160; 164

Ars 124

Asínio Polião 63; 131 n.29; 147; 191

Assonância 59

Atenas (Atene) 11 n.1; 65; 180 n.17

Auaritia 130; 187. Avareza 188

Auctor 49 n.2; 86; 169 n.29

Auctoritas 28

Augusto, imp. 8; 12; 21 n.25 e 26; 25; $26 ; 27$ n. $41 ; 29 ; 31 ; 31$ n.50; 32; 32 n. 51 e $52 ; 33 ; 34 ; 35 ; 37 ; 38 ; 39 ; 40$; 41; 42; 43; 44; 47; 58; 63; 65; 72; $74 ; 75 ; 77 ; 79 ; 80 ; 81 ; 82 ; 83 ; 87 ; 87$ n. 15 e $16 ; 90 ; 101 ; 103 ; 139 ; 144$; $150 ; 152 ; 153 ; 154 ; 166 ; 171 ; 172$; 181; 182 n.19; 197; 198; 205; 210

Octaviano 40; 41; 42; 166

Aurea mediocritas 158

Autor empírico 176; 177; 178; 179; 180

Autor textual 176; 179; 180 
Baias 129 n.19; 156; 158; 165

Bárbaros 12; 30; 31; 32; 32 n.52; 33; 68; 68 n. $3 ; 109 ; 145 ; 145$ n. $32 ; 161$ n. $84 ; 205$

Barbarismos 192

Beneficium 172

Bestiarii 123; 123 n.5

Bibliotecas 8; 74; 87; 125; 125 n.8; 159

Bílbilis $121 ; 124$ n.7; 135; 136; 141; 157 n.72; 159-161

Bruto 25; 40; 41; 42

Butroto 13-14

Cabana de Fáustulo 78; 80

Calvo 179

Campo 8; 55-57; 59; 60; 157; 158; 159

Campo de Marte 45; 68; 86; 167; 208; 209; 214

Campos Elísios 64

Capitólio/Monte Capitolino 7; 30; 31; $37 ; 38 ; 45 ; 77 ; 79 ; 86$

Cápreas 165

Captatio 138; 160

Carmina 38; 44-45; 51 n.6; 66; 73; 90; 191; 197

Caro 128; 194;

Carpe diem 46; 47; 132; 158;

Carras 40;

Cartago 14 -20; 15 n.10; 17 n.15; 19 n. $23 ; 21 ; 24$ n.33

Casa Romuli 77-78; 80

Cássio Longino 40; 41

Cássio de Parma 52

Catábase 19; 21; 22 n.28; 24 n. 33;

Catulo 50; 52; 53; 63; 64; 106; 120; $159 ; 179 ; 190$

\section{Causidicus 144}

Cena 122 n. $3 ; 127 ; 140 ; 141$ n.21; 143

\section{Cenatio rotunda 141}

César 11; 21; 21 n.26; 26; 26 n.38; 27; $32 ; 40 ; 42 ; 58 ; 90 ; 96 ; 151 ; 156$; 166; 167 n.18; 169;
169 n. $30 ; 171 ; 172 ; 173 ; 182$

Cícero 52; 58; 58 n.20; 97 n.43; 178; $179 ; 193 ; 202$

Cidadania/ciuis Romanus 7; 8; 65; 72; $116 ; 161$

Circo 11; 67; 83; 84; 96; 126; 156; 206 Circo Máximo 74; 78; 96; 98

Civilização 7; 8; 12

Claudiano 8; 201-214

Cláudio, imperador 141; 144; 150; 153; $177 ; 182 ; 192 ; 196 ; 197$

Cláudio Etrusco 127; 128 n.15; 156

Clélia 31

Cleópatra 31; 32 n.52; 43; 75

Cliens/Clientes/Clientela 23; 89; 91; 92; 122 n. 3 e 4 ; 124; 124-125 n.7; 127; 135; 139-141; 141 n. 20; 142; 145; 146; 151; 155; 157; 158; 159; 160; $180 ; 181$ n.17 e $18 ; 182 ; 184 ; 185$; $190 ; 195$

Colino 128

Colosso de Nero 121; 153; 153 n. 65; 156

Colosso de Rodes 167; 169 n. 30

Comédia Nova 52

Comitia centuriata 138; 208

Compitalia 79

Constantino 199

Constantinopla 202; 206; 207; 213

Cosmopolitismo 8; 11; 45; 120; 135; $153 ; 192$ n.36

Crasso 40

Crispino 128; 195; 197

Cubicularius 128

Cumas 165; 174; 194 n.38

Cunnilingus 148; 149 n.51; 190

Cúria 75; 76; 78; 94; 207; 208; 210; $211 ; 212$

Curia Hostilia 78

Curia Iulia 78; 80; 206; 209; 210

Deuotio 168; 188 
Dicacitas 150

Dido 15-19; 15 n.10; 17 n.15; 22; 24; 24 n. 33; 35; 35 n.60; 192

Diuus 127. Divindade $13 ; 33 ; 37 ; 43$; 44; 154; 164 n.9; 168; 170; 173; 174; 186; 197; 210

Domiciano, imp. 123; 124; 125; 125 n. $9 ; 126 ; 126$ n.12; $127 ; 127$ n.14; 128 ; $139 ; 140 ; 144 ; 150 ; 153 ; 154$; $156 ; 163 ; 164 ; 164$ n.8; 165; 165 n.11; 166; 167; 168; 168 n.28; 169; 169 n. $31 ; 170 ; 172 ; 173 ; 174 ; 174$ n. $48 ; 185 ; 196 ; 197 ; 198$

Domício Apolinar 127; 128 n.15

Domus Aurea 121; 136; 141; 153

Domus Flauia 128; 165

Drépano 21

Eárino 128; 165

Ekphrasis 27 n.41; 31; 53; 156

Elegia 8; 49-64; 49 n.2; 50 n.4; 54 n.9; 65-82; 83-103; 96 n.40; 100 n.51; 101 n.57; 109; 110; 112; 114 n.11; 118; 119; 130; 189; 190

Eleições 155; 208; 209; 214

Eneias 8; 11-35; 105; 193; 194; 194195 n. 38

Entelo 128; 128 n.16

Epopeia 8; 15 n.10; 22; 24; 28; 166; 167 n. $23 ; 175$

Epicteto 124

Epigramas 121-133; 135-161; 182 n.21

Epitalâmio 53; 164

Epodos 42; 158 n.75

Eques 51; 57; 123; 126; 143; 144; 146; 183

Espaço físico 11; 13; 45; 161

Espaço ideal 13

Espaço urbano 11; 151 n.60; 152

Esquilino 66; 70; 87; 155; 156

Estábias 165

Estácio 8; 124; 163-174; 184; 194-195 n. 38
Estado 23; 24; 25; 26 n. 38; 27; 126; $181 ; 196$

Estilicão 200; 203; 204-208; 210-214

Etruscos 29

Eufemo 128; 128 n.16

Eutrópio 204; 207

Evandro 28; 29; 30; 31; 33; 79

Fama 18; 21; 50 n.4; 70; 118; 121; 124; $136 ; 159 ; 160 ; 166$ n.18; 203

Familia 127; 128; 150; 169 n. 30; 203

Farsalo 39

Fatum 13; 19

Fellatio 148; 149 n.51; 189

Feriae Latinae 79

Fides 19 n.21; 23; 140

Filipos 40; 41; 42

Filóstrato 124

Flávios 8; 121-133

Foedus amoris 67; 70; 86

Fortuna 211; 214

Fortuna Redux 204-206; 208; 209

Forum 8; 39; 45; 66; 67; 69; 80; 89; 90; $91 ; 100$ n. $53 ; 101 ; 118 ; 156 ; 158$; $168 ; 172 ; 173 ; 177 ; 184 ; 203 ; 206$

Forum Iulium 90; 156

Forum de Trajano 203

Forum Cornelii (Ímola) 140

Fundação de cidades $8 ; 13 ; 15$ n. 10; 26; $27 ; 165 ; 202 ; 205$

Furor 17 n.15; 33; 34; 34 n.59; 62 n. 29; 109

Galo, Cornélio 49; 50-51; 118

Gauro 165

\section{Genethliacon 54}

Gigantomachia 202

Guerra 20 n. 24; 22 n.30; 27; 21 n.40; $28 ; 32 ; 37 ; 39 ; 41 ; 46 ; 49 ; 56$; 58; 62; 63; 64; 166; 168; 169 n.30; 197; 204; 207; 208; 210; 211

Guerras Civis 11; 21; 27; 27 n.41; 32; 32 n. $51 ; 39 ; 40 ; 45 ; 51 ; 125$; 
Índice temático

$135 ; 137 ; 169$

Guerras Púnicas 15; 20

Guerra Social 39; 41

Guerra de Tróia 16

Hecatóstilo 155

Heredipetae 138-139

Hipérbole 41; 145; 148

Hispânia 161

Hispânia Citerior 127

Hispânia Tarraconense 121; 125; $135 ; 136 ; 158 ; 159 ; 160 ; 161$

Honório 8; 199-214

Horácio 8; 37-47; 52; 61; 62; 63; 64; 77; 82;118; 138 n.7; 149; 154; 156; $157 ; 158$ n. $75 ; 159 ; 179 ; 180 ; 181$; 182 n. $19 ; 184 ; 185 ; 189$ n.33; 197; 212

Horácio Cocles 31

Hybris 75

Idade de Ouro 25; 64

Imitação 14; 153 n.65; 175; 185

\section{Imitatio 14}

Imperium 27; 28; 29;30;37;39; 54 n.10; 80; 152 n.62; 154. Império 7; $8 ; 13 ; 21 ; 25 ; 27 ; 28 ; 29 ; 30 ; 33 ; 34$; $35 ; 42 ; 63 ; 64 ; 121 ; 123 ; 135 ; 135$; 136; 137; 137 n.3; 140; 144; 153; 172; 185; 197; 200; 201; 202; 205; 206; $210 ; 213$

Indignatio 178; 179; 187; 188; 189

Ingenium 58; 58 n.22; 124; 159

Insulae 135

Inuentio 84; 85; 90; 92; 93; 94; 96; 103

Ira 33

Instância(s) de enunciação 175 ; 177 ; 178; 179; 180; 184; 185; 191; 192; 193; 194; 195; 196; 197; 198

Istâncio Rufo 127; 128 n.15

Ius $62 ; 62$ n.29; 91 n.26; 152 n.62

Ius Latii 161

Ius trium liberorum 123; 185

Jogos 11; 37; 44; 144; 115; 121; 123;
125; 126; 128; 165; 180 n.17; 181; 201. Vide Ludi

Jogos Florais 151

Jogos Megalenses 190

Jogos Napolitanos 163

Jogos Plebeus 190

Jogos Seculares 38

Júlio Rufo 149

Justiça $16 ; 22 ; 23 ; 30 ; 62 ; 135 ; 182$ n. $21 ; 195$

Juvenal 8; 124; 124 n.7; 128; 138 n.7; 140 n. $13 ; 141$ n. $20 ; 145$ n. $35 ; 146$ n. $36 ; 151$ n. $60 ; 159 ; 175-198 ; 202$

Kairos 38; 42

Labor limae 151

Lanúvio 70

Laudes: Italiae 65; 84. da Hispânia 161 Laus Vrbis 152

Lei/Lex/Leges 12.n.5; 16; 20 n.24; 21; 23; 31; 96; 97; 109; 116; 125; 125 n. $9 ; 129 ; 143 ; 150 ; 170 ; 176 ; 179$

Lei Escantínia 196

Lex Iulia de adulteriis coercendis 24; 126; 130; 139; 150

Lex Roscia theatralis 126; 144

Leitmotiv 31; 32 n.52

Leitor 30; 33; 38; 39; 59; 121; 135; 137; $149 ; 155 ; 156 ; 161 ; 165 ; 176 ; 179$

Libelli 100; 101; 101 n.55; 151; 160 n. $79 ; 187$

Libertos 41-42; 121; 128; 129; 143144; 183; 184; 191

Licínio Sura 127; 128 n.15

Lucano 178; 194 n.38

Lucílio 179; 181; 185; 195

Lucrécio 118

Ludi 67; 123 Vide "Jogos”

Ludi Albani 128

Ludi Capitolini 128

Ludi Saeculares 38; 44; 81

Lupercal 30 
Lupercalia 79

Luxuria 46; 143; 148; 189; 192; 197; 198

\section{Maiestas 153}

Marcial 8; 121-133; 135-161; 172; 173 n.43; 182; 182 n. $21 ; 183 ; 183$ n.22; 184; 185; 187; 190; 193; 195

Marco António 27 n.41; 31; 32; 32 n.51 e $52 ; 40 ; 41 ; 63 ; 179$

Marco Aquílio Régulo 128

Mecenas 39; 40; 43; 63; 131 n.29; 181; 181 n.19

Mediterrâneo 15; 136; 200; 201; 202

Meretrix 66; 70; 72; 89 n.21

Messala Corvino 57; 58; 58 n.21; 60; $62 ; 63$

Milão 199; 200; 201; 203; 206; 207; $208 ; 209 ; 210 ; 213$

Miseno 165

Mores 144

Mos 30 n.49

Mos antiquus 126

Mos maiorum 63; 150

Municipium 163

Nápoles 11 n.3; 163; 164; 165; 165 n.12

Narrador 177; 182; 186; 191; 192; 194 n. 38

Natureza 11; 22; 33; 39; 187

Náuloco 73; 75

Nero, imperador $121 ; 122 ; 135 ; 136$; $140 ; 141 ; 148 ; 150 ; 152 ; 153 ; 155$; $163 ; 164 ; 182 ; 197$

Nerva, imperador 124; 127

Numa Pompílio 25

Officium 97; 98; 99; 125 n.7; 127

Ópio 87

\section{Opportunitas 88}

Otão, imperador 136; 137;137 n.3; 144; 198

Ovídio 8; 49; 50; 58; 63; 64; 83-103; 105-120; 132 n.33; 155 n.69; 158; $160 ; 160$ n. $82 ; 161$ n. $84 ; 189 ; 202$
Pai da Pátria 154

Palante 33; 34; 194-195 n.38

Palatino 37; 75; 77; 78; 79; 80; 83 n.1; 87; 87 n.15; 88 n.17; 96; 128; 154; 156; 167 n.18; 199; 205; 208; 212

Palatium/Palatia 76; 128; 154

Panegírico $8 ;$ 54; 57; 163; 165; 166; $167 ; 169 ; 173 ; 199 ; 214$

Panteão 209

Paraklausithyron 54

Parilia 76; 79

Parténio, elegista alexandrino 50

Parténio, cubicularius de Domiciano $128 ; 128$ n.16

Partitio 83; 83 n.4

Pátria $8 ; 13 ; 14 ; 23 ; 26$ n.36; 27 n.40; $65 ; 66 ; 73 ; 86 ; 135 ; 157 ; 161 ; 166$ n. $18 ; 168$

Patriai 202

Patronus 89; 91; 91 n.26; 92; 140; 144

Paupertas 11; 30; 51; 52

Pax Augustana 29; 42

Pax Romana 8; 12; 27; 28; 29; 30; 31; $32 ; 33 ; 56$ n. $13 ; 136$

Penates 13 n. $6 ; 31$

Pérgamo 74

Persona(e)49; 51; 52; 53; 178

Perspectiva $18 ; 20 ; 23 ; 26 ; 26 ; 26$ n.38; $27 ; 62 ; 121 ; 124 ; 131 ; 142 ; 165$; n. $11 ; 169$ n. $31 ; 204$

Pietas 23; 25; 35 n.60; 61

Pitecusas 165

Plínio o Moço 124; 127; 128; 128 n.15; 140 n. $13 ; 141$ n.20; 155; 156; 178

Plínio o Velho 145; 148 n.42; 155 n.67; $161 ; 186$

Poikilia 54; 55

Poliptoto 87; 98

Pólis 12; 45

Pomoerium 13

Pompeio Magno 26; 27; 32; 39; 155 
Índice temático

Pompeio, Sexto 179

Porsena 31

Porta Carmental 30

Pórtico de Apolo 73; 87; 87 n.16; 88 n.17

Pórtico dos Argonautas 155

Pórtico de Lívia 87; 87 n.15

Pórtico de Octávia 87

Pórtico de Pompeio 67; 86; 155; 88 n. $18 ; 89 ; 155$

Pórtico de Vipsânia 155

Praeceptum/praecepta 85; 86; 88; 89 n.20; 92; 93; 94; 97; 98; 100; 103

Praeceptor 92; 93; 94; 95; 97; 99

Priapea 57

Princeps 41; 42; 43; 44; 50 n.3; 61; 90; $121 ; 123 ; 125 ; 126 ; 128 ; 154 ; 201$

Principes 121; 127

Príncipe 14; 21 n.25; 72; 74; 75; 79; 81; 82; 199; 200; 201; 203; 206; 207

Propaganda 8; 21 n. $25 ; 32$ n.52; 33; 42; $81 ; 125 ; 137 ; 153$

Propércio 8; 49; 50; 52; 53; 54; 54 n. 9; 58; 64; 65-82; 83; 84; 85; 87 n.16; 106; 114 n.11; 120; 166; 166 n.18; $167 ; 189 ; 190$

Províncias 12; 125 n.8; 135; 136; 137; 160; 196; 198; 201

Pudicitia 126; 130 n.23

Puer 27; 59; 132

Puer Veneris 100; 101

Puer delicatus 128

Quintiliano 49; 58; 61; 124; 128; 131 n. $25 ; 144 ; 178 ; 186$

Remo 13; 31; 105

Representação $16 ; 31 ; 111 ; 135 ; 136$; 152; 155; 194 n.38

República $8 ; 11 ; 41 ; 42 ; 47 ; 140 ; 168$; $172 ; 179 ; 197 ; 209$

Respublica 12; 33

Rixae amoris 55; 55 n.11; 56; 56 n.14; 130
Rocha Tarpeia 30; 79-80

Roma passim

Urbe $7 ; 8 ; 12 ; 15 ; 37 ; 41 ; 45 ; 77$; $135 ; 136 ; 137 ; 138 ; 140 ; 146$; $151 ; 152 ; 153 ; 154 ; 155 ; 156$; $157 ; 158 ; 160 ; 161 ; 161$ n. 84; 197; 198; 199; 200; 201; 205; 206

Vrbs 37; 47; 69; 83; 84; 102; 102 n. $60 ; 105 ; 152$ n. $62 ; 160 ; 201$

Vrbs Aeterna 45

Romanidade 14; 19; 30; 33; 49; 61; 64

Rómulo 13; 25; 26; 30; 31; 105; 166 n. $18 ; 168$

Rúbrio Galo 197

Rufino 207

Sabinas 31

Saepta Iulia 155; 209

Sálios 31; 32

Salústio 202

Salutatio 157

Sátira $8 ; 41 ; 42 ; 45 ; 46 ; 137 ; 149 ; 175-$ 197

Sátira Menipeia 177; 197

Satura $128 ; 188$

Séneca 58; 122; 129; 129 n.20; 130; 130 n.23; 142 n. $22 ; 148$ n. $46 ; 151$ n.60; 177 n.7; 178; 188; 192

Seruitium amoris $51 ; 130$

Sílio Itálico 124; 127; 127 n.15; 194 n.38

Simplicitas 11; 30; 149

Sportula 122; 127; 139; 140; 140 n.14 e $16 ; 141 ; 183 ; 184$

Suburra 66; 72; 142; 145 n.34; 155; 156

Suetónio 39 n.1; 43; 50; 124; 137 n.3; 141 n. $19 ; 144 ; 148$ n. $43 ; 149$ n.50; 150 n.56; 152 n.62 e $63 ; 153 ; 182$; $193 ; 197$

Sujeito poético 181 n.17 e 19; 182; 182 n.19; 183; 183-184 n.22; 185; 188; 189; 190; 191; 192 
Surrento 165

Tácito 58; 124; 128; 137; 163; 178; 193

Tarento 46; 171; 210

Tarquínios 25

Teatro(s) 8; 16; 67; 68; 74; 83; 84; 92; 93; 93 n.31; 94; 95; 96; 114; 125; 125 n. $8 ; 144 ; 154 ; 156 ; 159$

Teatro de Marcelo (Theatrum Marcelli) 78

Teatro de Pompeio 78; 86; 155

Teatro de Nápoles 164

Templos 8; 126; 154; 156; 164; 165; 169 n.30; 171; 181 n.17; 204; 205; 209

Templo de Apolo 31; 166

Templo de Castor 156

Templo da Concórdia 169

Templo de Hércules (Nápoles) 164-165

Templo de Ísis e Serápis 155; 167

Templo de Jano Quadrifronte (no Argileto) 172; 173; 173 n.44;

Templo de Júlio César 169

Templo de Juno (Cartago) 16; 202

Templo de Minerva 172; 173

Templo da Paz 172; 173

Templo de Tito e Vespasiano 154; 169

Templo de Venus Genetrix 89; 90-91

Templo de Vesta 39; 156

Templo da Vitória (209); 210; 212

Teodósio, imperador 199; 203; 206; $208 ; 210 ; 212 ; 213$

Teodósio II, imperador 201; 202; 45; 199; 203

Tibério, imperador 90; 127

Tibre 28; 39

Tibulo 8; 49-64; 106; 118; 130

Tíbur/Tivoli 46; 74; 158; 185

Timor 63 n.30; 187; 188

Tiro 16; 195
Tito, imperador $122 ; 123 ; 125 ; 127$; 127 n. $14 ; 153 ; 154 ; 155 ; 169 ; 195$

Tito Lívio 82; 179; 191

Trajano, imperador $124 ; 127 ; 144 ; 178$; 182; 201; 203

Tróia / Ílio 12 n.4; 13; 14; 14 n.9; 16; 169 n.30; 194; 194 n.38; 198

Tulo Hostílio 25

Turno 30; 33; 34

Variatio 135

Vário Rufo 43

Varrão 82; 118; 168 n.26; 179; 187; 197

Venatio $123 ; 123$ n.5

Venúsia 45

Vespasiano $125 ; 136 ; 137 ; 148 ; 149$ n. $50 ; 152 ; 153 ; 169 ; 195$

\section{Vestalia 79}

Vias 8; 67

Via Ápia 177

Via Domiciana 165; 174

Via Flamínia 199; 200; 205

Via Sacra 66; 156

Virgílio 7; 8; 11-35; 66; 82; 90; 93; 118; $157 ; 184 ; 192 ; 193 ; 194 ; 194-195$ n. $38 ; 197$

Virtudes 17 n.14; 21 n.25; 34; 78; 85; $154 ; 188$

Vita rustica 157

Vita urbana 157

Vitélio, imperador 125; 136; 137; 144

Vitia/Vícios 39; 62 n.28; 141 n.20; 142; 152; 178; 179; 182 nn.21; 187; 188

Vitia corporis 149

Voluptas 108; 159; 187; 188

Zenão, imperador 202 


\section{Volumes publicados na Colecção Humanitas SuPPLEMENTUM}

1. Francisco de Oliveira, Cláudia Teixeira e Paula Barata Dias: Espaços e Paisagens. Antiguidade Clássica e Heranças Contemporâneas. Vol. 1 - Linguas e Literaturas. Grécia e Roma (Coimbra, Classica Digitalia/CECH, 2009).

2. Francisco de Oliveira, Cláudia Teixeira e Paula Barata Dias: Espaços e Paisagens. Antiguidade Clássica e Heranças Contemporâneas. Vol. 2 - Linguas e Literaturas. Idade Média. Renascimento. Recepşão (Coimbra, Classica Digitalia/CECH, 2009).

3. Francisco de Oliveira, Jorge de Oliveira e Manuel Patrício: Espaços e Paisagens. Antiguidade Clássica e Heranças Contemporâneas. Vol. 3 - História, Arqueologia e Arte (Coimbra, Classica Digitalia/CECH, 2010).

4. Maria Helena da Rocha Pereira, José Ribeiro Ferreira e Francisco de Oliveira (Coords.): Horácio e a sua perenidade (Coimbra, Classica Digitalia/CECH, 2009).

5. José Luís Lopes Brandão: Máscaras dos Césares. Teatro e moralidade nas Vidas suetonianas (Coimbra, Classica Digitalia/CECH, 2009).

6. José Ribeiro Ferreira, Delfim Leão, Manuel Tröster and Paula Barata Dias (eds): Symposion and Philanthropia in Plutarch (Coimbra, Classica Digitalia/CECH, 2009).

7. Gabriele Cornelli (Org.): Representaçôes da Cidade Antiga. Categorias históricas e discursos filosóficos (Coimbra, Classica Digitalia/CECH/Grupo Archai, 2010).

8. Maria Cristina de Sousa Pimentel e Nuno Simões Rodrigues (Coords.): Sociedade, poder e cultura no tempo de Ovidio (Coimbra, Classica Digitalia/ $\mathrm{CECH} / \mathrm{CEC} / \mathrm{CH}, 2010$ ).

9. Françoise Frazier et Delfim F. Leão (eds.): Tychè et pronoia. La marche du monde selon Plutarque (Coimbra, Classica Digitalia/CECH, École Doctorale 395, ArScAn-THEMAM, 2010).

10. Juan Carlos Iglesias-Zoido, El legado de Tucídides en la cultura occidental (Coimbra, Classica Digitalia/CECH, ARENGA, 2011).

11. Gabriele Cornelli, O pitagorismo como categoria historiográfica (Coimbra, Classica Digitalia/CECH, 2011).

12. Frederico Lourenço, The Lyric Metres of Euripidean Drama (Coimbra, Classica Digitalia/CECH, 2011). 
13. José Augusto Ramos, Maria Cristina de Sousa Pimentel, Maria do Céu Fialho, Nuno Simões Rodrigues (coords.), Paulo de Tarso: Grego e Romano, Judeu e Cristão (Coimbra, Classica Digitalia/CECH, 2012).

14. Carmen Soares \& Paula Barata Dias (coords.), Contributos para a história da alimentação na antiguidade (Coimbra, Classica Digitalia/CECH, 2012).

15. Carlos A. Martins de Jesus, Claudio Castro Filho \& José Ribeiro Ferreira (coords.), Hipólito e Fedra - nos caminhos de um mito (Coimbra, Classica Digitalia/CECH, 2012).

16. José Ribeiro Ferreira, Delfim F. Leão, \& Carlos A. Martins de Jesus (eds.): Nomos, Kosmos E Dike in Plutarch (Coimbra, Classica Digitalia/CECH, 2012).

17. José Augusto Ramos \& Nuno Simões Rodrigues (coords.), Mnemosyne kai Sophia (Coimbra, Classica Digitalia/CECH, 2012).

18. Ana Maria Guedes Ferreira, O homem de Estado ateniense em Plutarco: o caso dos Alcmeónidas (Coimbra, Classica Digitalia/CECH, 2012).

19. Aurora López, Andrés Pociña \& Maria de Fátima Silva, De ayer a hoy: influencias clásicas en la literatura (Coimbra, Classica Digitalia/CECH, 2012).

20. Cristina Pimentel, José Luís Brandão \& Paolo Fedeli (coords.), O poeta e a cidade no mundo romano (Coimbra, Classica Digitalia/CECH/CEC, 2012). 

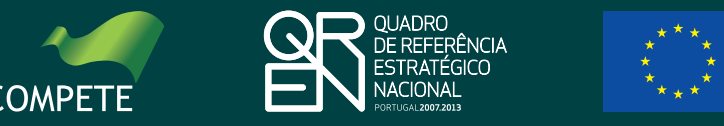